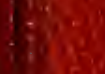

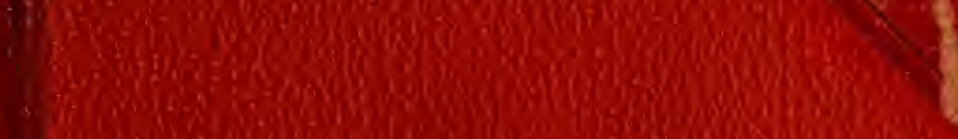
S 

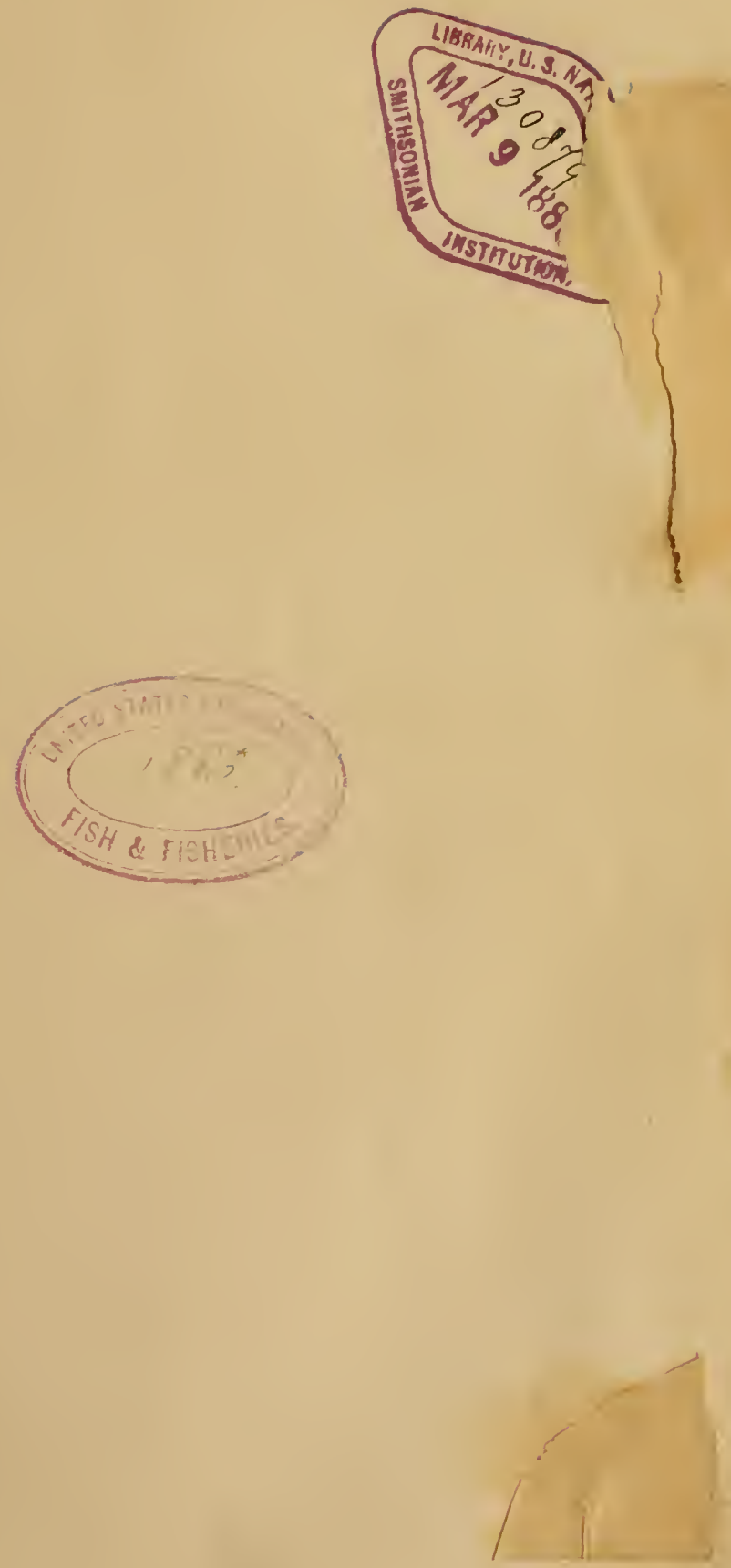



\section{INVERTEBRATE \\ - ZOOLOGY. \\ Crustacea}







. 



\title{
REPORT ON THE MARINE ISOPODA OF NEW ENGLAND AND ADJACENT WATERS.
}

\author{
BY OSCAR HARGER.
}

[From the Report of the Uxithd States Commissioner of Fish and Fisheries, PART VI, FOR 1878.] 



\section{REPORT ON THE MARINE ISOPODA OF NEW ENGLAND AND ADJACENT WATERS.}

By Oscar Harger.

The following paper includes the species of Isopoda at present known to inhabit the coast of New England and the adjacent regions, as far as Nova Scotia on the north and New Jersey on the south. These limits have been chosen from the fact that nearly all the marine collections of this order made by the Fish Commission have been from the New England coast, except those from the Nova Scotia coast in 187\%, while the commission had its headquarters at Halifax. Previous to the work of the Fish Commission extensive collections hat also been made, mostly by Professors A. E. Verrill and S. I. Smith, of Yale College, in the Bay of Fundy and at other places along the coast as far south as Great Egg Harbor, in the southern part of New Jersey. The collections thus obtained, and others in the museum of Yale College, have, through the linduess of Professor Verrill, been used in the preparation of this article. As there has not ret been sufficient opjortunity for the study of the Bopyrida, only a list of the known species of that family is included, and for this I am indebted to Professor S. I. Smith. The species of the remaining families are described at length, and nearly all figured in more or less detail in the plates accompanying the article. Throughout the article especial reference will be had to the Isopoda of our own coast, and many peculiarities of structure, not found in our genera, will be more or less completely disregarded. As the Oniscidce are a terrestrial family, only a fer species, found usually, or only, along the shore are here included.

\section{ISOPODA.}

This group is an order of Crustacea, so named from two Greek words, ¿\%os, equal, and $\pi \circ{ }^{\prime}$, a foot, from the general similarity of the legs throughout, all being thoracic. The order belongs to the Tctradecapoda, "fourteen-footed," called also Edriophthalma, or "sessile-eyed" Crustacea. All of these terms, however, require modification when applied to the animals included in this order, since in the genus Astacilla the anterior pairs of legs are quite mnlike the posterior, in Gnathin there are never more than twelve feet, or legs, in six pairs, and lastly in Tanais and its allies the eyes, when present, are not sessile, but articulated with the head, or stalked, as in the higher Crustacea. It may, however, be stated that 
the relations of the Tanaide with the rest of the order are remote, and it is perhaps doubtful whether they should be retained among the Isopoda, espeeially as this family differs from the rest of the order in its mode of respiration, as will be explained hereafter.

Although this order is not a large one its representatives are perhaps more widely distributed than in any other order of Crustacea. Every one is familiar with "sow-bugs" or "pill-bugs," which are found eren in damp houses and in cellars, as well as under leaves in woods or nnder almost any pile of rubbish among deeaying vegetable matter. These terrestrial species do, indeed, become rare in the colder parts of the world, but are found as fin north as Greenland. Other speeies less fumiliar, but perhaps hardly less abundant, inhabit ponds and streams of fresh water, and others are found along the shores of all oeeans; yet others abound among the marine vegetation of the shallow waters, or fix themselves upon the bodies, or within the mouths of fishes and other marine animals. Species are found swimming free in the open ocean, and others are brought up from the greatest depths to which the dredge has yet penetrated.

It will be convenient to give here a brief general aceount of the strueture of the animals eomposing this order, and an explanation of the terms used in their description. Most of our marine species have a greater or less number of the segments at the posterior end of the body coalescent, but in the genus Cirolana they are distinet; the animals are, moreover, of large size and very abundant in some localities; reference will therefore be constantly made to the figures of Cirolana concharum, on plates IX and $\mathrm{X}$, in illustration of the parts of the animal and of the terms used. A few speeimens of this animal will help materially in gaining a knowledge of the structure of the group; or, if specimens of Cirolana camnot be obtained, a common "sow-bug" (Oniscus or Porcellio) may be substituted.

The body appears to consist of fourteen segments, of which the first is the head; the next seren form the thorax, or pereion of Spence Bate, and the last six the pleon, sometimes ealled the abdomen. Returning to the head we find, looking from above, a pair of eyes-each consisting of a group of ocelli-and two pairs of antennary organs. Of these the upper pair, or antenunla (pl. X, fig. 60), consist on each side of three comparatirely large basal segments, which, together, are ealled the peduncle, or perlmenlar segments, and support a more slender and tapering flagellnm or lash, composed of a considerable ummber of short seg. ments, decreasing in diameter toward the tip, and each, usually, bearing a fascicle of setie, which are ealled by Fritz Miiller olfactory setre, from their supposed function. The antennula are very small and rudimentary in "sow-bugs" and their allies. Below the antenuula are the antenne properly so called (pl. X, fig. (61 $a$ ), which are also eomposed of a peduncle aud flagellum. The five basal segments constitute the peduncle, and the following, usually much shorter and smaller segments, are flagellar. 
Underneath, the month is seen to be proteeted by a pair of organs called maxillipeds (pl. X, fig. $62 a$ ), with which, for convenience of dissection, we shall eommence the description of the parts of the mouth. The five terminal segments of the maxillipeds in Ciroluna (numbered 1 to 5 in the figure) constitute the palpus, but this number varies in the different genera. They are articulaterl to the external surface of the large basal segment (m), usually proportionally much larger than in Cirolanu, as in Idotea phosphorea (pl. V, fig. $28 b, m$ ), or in the "sow-bug" where the palpus is greatly redneed. The basal segment of the maxilliped is, in general, prorluced internally bejond the origin of the palpus, and furnished with strongly plumoso or peetinated setre at the tip. Frequently along its inner margin one or more short styliform organs are attached, as in Jera albifrons (pl. I, fig. 5), while along its basal margin is a more or less distinet snture, indicating the epimeral segment of this organ, which will be further explained. The basal segments of the opposite maxillipeds meet along the median line, where their margins are nearly straight, and to the base of the onter margin is attached a more or less triangular external lamella (pl. X, fig. $62 a, l)$. The name "maxilliped" is frequently used for the basal segment only, which is often, as in the "sow-bugs," much larger than the rest of the organ and serves to cover and protect the other organs of the mouth.

When the maxillipeds are removed we find two pairs of maxillæ, the outer and inner; of these the outer, or second pair (pl. X, fig. $61 b$ ), are in general of a delicate texture, and three-lobed at the tip, the two outer lobes being articulated to the basal piece, and all three lobes ciliated on their inner margins. The inner, or first pair of maxillæ are of a less delicate texture than the outer, and are hardly of the ordinary form in Cirolana (pl. X, fig. $61 \mathrm{c}$ ); reference may, therefore, be made to Synidotea nodulosa (11. VI, fig. 35 c), where the two unequal lobes are shown, the inner comparatively small, aud supported on a slender peduncle, curved intrard, truncated at the tip, aud bearing stout, curved, pectinated setæ; the outer mueh more robust and larger, similar in general outliue to the inner, but armed with stout, curved, denticulated spines at the tip.

The unandibles (pl. X, fig. $61 d$ ) are usually toothed at the apex, the teeth being supported on a dentigerous lamella, which may be double on one mandible, usually the left, and receive the lamella of the opposite mandible betreen the two; below this lamella is often a comb of pectinate setre, and, generally, a molar process, as in Junira alta (pl. III, fig. 1' $b, m)$. In many genera a three-jointed palpus (pl. $\mathbf{X}$, fig. $61 d, p$ ) is articulated to the external surface of the mandible, and, usually, the terminal segment of the palpus is more or less semicircular, or curved, and bears on its inner margin a very regular comb of setre (1)l. III, fig. $12 b$ ), apparently of service in eleansing the organs of the month. This comb may be continued or repeated on the second segment, as in Cirolana (pl. X, fig. $61 d, p$ ). In the "sow-bug" and many other genera the 
mandibles are destitute of palpi. The oral opening between the mandibles is defended by an upper and lower lip, or labrum and labium, which are, however, median, and not paired organs, like the other parts of the mouth.

The seren thoracie segments are of firm texture above, but softer underneath. The dorsal surface is in general more or less rounded, and in Cirolana is continued well down at the sides, where, except in the first segment, it is crossed by a suture cutting off a quadrate, or somewhat triangnlar piece, called an epimeron, or, in the plural, the epimera. The epimera are well shown in the side view of Cirolana concharum (pl. IX, fig. 58). They belong to the legs, and form a portion of the large proximal segment called the coxa. Usually, howerer, the legs are figured as in pl. X, fig. $62 b$, without this segment, which adheres strongly to the body; often, as in the first segment of Cirolana, the suture sep. arating it disappears. The remaining six segments of the legs are more slender, and are called respectively, beginning with the segment following the coxa, the basis, ischinm, merus, carpus, propodus, and dactylus, the last being usually slender and eurved, often bearing a curved spine or claw at the tip, and, especially in the first pair, capable of flexion on the propodus, so as to form a prehensile hand. In the Tanaidre, as in many of the higher Crustacea, the propodus may be prolonged into a digital process, against which the dactylus closes, forming a chela (1)l. XIII, fig. S5), or ehelate haud, as in the lobster. In the Aigide aud tho Cymothoidce a greater or less number of the dactyli are strongly eurved or hooked, for the purpose of retainiug firm hold of the host, on which these parasitic species live. Legs thus eonstrueted are called ancornl, as in Livoneen ovalis (pl. XI, fig. $67 d$ and $e$ ).

Of the seven pairs of legs attached to the thorax or pereion, the first three have in general a resemblanee to each other, aud are often more or less prehensile, while, as in Chiridotea (pl. IV, figs. 16 and 20), the last four are more strietly locomotive organs; but to this condition of things there are many exceptions, espccially in the derelopment of the first pair of legs, which are quite variable throughont the order, being not even pediform in the males of the Gnathiida, but tro-jointed, in our species, and lamelliform (pl. XII, fig. $76 d)$. Except in this family, howerer, no confusion arises from speaking of the thoracie appendages as the first to the serenth pair of legs, or thoraeic legs, and in general these terms will be used except where it may be necessary to use the technical terms, gnathopods or guathopoda and pereiopods or pereiopoda, for these organs, as proposed by Spence Bate, aceording to whose system the first and second pairs are called the first and second pair's of guathopoda* or gnathopods, and the remaining five pairs the first to the fifth pair of pereiopoda or pereiopods. When necessary these terms will be added as explanatory, having the merit of seientific accuracy as well as applicability to other groups of Crustacea, where a 
marked distinetion of strueture and function frequently occurs between the organs homologous with the second and third pairs of legs in the Isopoda.

In the adult females of this order there is commonly formed, on more or less of the under surface of the thorax, an incubatory pouch for the reception and derelopment of the eggs. 'The outer' surface of the pouch is usnally formed by four pairs of lamellie attached just within the origins of the second, third, and fourth, together with the first or fifth pairs of legs, and in the females of many genera, Spheroma and Ascllus for instance, these lamella may be observed in a rudimentary condition on the under surface of the thorax when not actually in use carrying engs or young. In Asellus, and in some other genera, they are fond upon the first to the fourth segments, instead of the seeond to the fifth. In Anthura the ineubatory pouch extends over only three segments, the third, fourth, and fiftl, and in Astacilla it is confined to a single segment, being composed of a single pair of elongated plates attached to the fourth segment. In Tunais a firtlier remarkable variation oceurs, and the eggs and young are carried in sacs attached to the under surface of the fifth thoracie segment, while in the closely allied genus Leptochelia the form of the incubatory pouch is normal. In the Guathiidte and Anthurila, according to Spence Bate and Dohrn, the incubatory ponch is formed by the splitting of the integument of the inferior surface of the thoracie segments in the females, and for the discharge of the young the outer lamella thus formed further divides into seales, one pair for each segment of the ponch. In Jorn, Epelys, and probably other genera, a similar mode of development scems to oceur.

The six segments of the pleon are smaller than those of the thorax, often much smaller, and frequently more or less united, sometimes consolidated into a single piece with searcely any trace of division above, but the number of pairs of appendages is generally six, showing the composite nature of the apparently simple organ. Of these six pairs of appendages or pleopods, the tirst five are more or less concealed beneath the pleon, and consist on each side of a basal seginent bearing two lamellæ (1)l. IV, fig. $19 \mathrm{c}$ ), of which the outer is the anterior when they overlap. These lamelle, at least the anterior pairs, are usually ciliated along more or less of their distal margins with loug slender plumose setx. In the males of most of the genera, the inner lamella of the secoud pair bears, articulated near the base of its inner margin, a slender stylet $(p l . I V$, fig. $19 l, s)$. This stylet seems to aftord, in mauy cases, specific aud even generic characters.

The last segment, sometimes called the telson, has its pair of append. ages specially modified, and called the uropods (1)l. X, fig. 63). They consist in general like the pleopods of a basal segment bearing two lamelle, or rami, not being always lamelliform, and in the Tanaide they are more or less segmented (pl. XIII, fig. S6). One of these rami may disappear, as in Spharoma and in some of the Idoteide (pl. V, fig. '25 c), where a further modification takes place, and the uropods are so articu- 
lated to the inferior surface of the pleon as to fold together like a pair of eupboard doors, forming an operculum for the protection of the more delicate pleopods. Except in the Tanaida, respiration is carried on by means of the pleopods.

In the Asellide, Idoteide, and some other families two or more of the segments of the pleon are uniter, so that, seen from above, the pleon, like the head, may appear to consist of a single segment, as in Jcera albifrons (pl. I, fig. 4), but the number of pairs of its appendages, usually six, remains as evidence of this consolidation. In like manner the head is to be regarded as composed of sereral segments united, and the number of such segments is indicated by the number of pairs of appendages. In the Tanaidce and many of the higher Crustacea, the eyes, more or less distinctly stalked or articulated with the head, are seen to be of the nature of a pair of appendages, which may be regarded as belonging to the first cephalic segment. The antennulæ and antennæ represent, respectirely, the second and third cephalic segments, and, in like manner, the mandibles and two pairs of maxillæ represent the fourth, fifth, and sixth segments of the head. A seventh segment is indicated by the maxillipeds. This segment is regarded by Huxley as properly thoracic* instear of cephalic, but, for purposes of description, the segment and its appendages will be regarded as belonging to the head, and the next segment considered the first thoracic.

This segment, like the following thoracic segments, is nsually free, and has the dorsal region well developed, but in the adult Gnathia it is united with the head, and still more elosely so in the Tanaide. The seventh thoracic segment is the last to develop, and in young Isopoda, taken from the incubatory ponch, only six pairs of legs are commonly found. In Gnathia this condition prevails through life, and in the adults the first pair of legs are also modified, especially in the males, so as to quite lose their pediform eharacter, leaving apparently only five pairs of legs. Furtlıer modifications of structure will be described in the families and genera in which they oceur.

The nomenclature adopted, as explained above, corresponds nearly with that proposed by Mr. C. Spence Bate in his Report on British Edriophthalma, and nsed by the anthors of the British Sessile-eyed Crustacea.

The length of an Isopod, in the present article, is given as the length of the body, exclusive of appendages, and is measured from the front of the head to the tip of the pleon. When, as in Janira, the head is produced medially into a "rostrum" (see pl. II, figs. 9 and 10), the measurement is taken from the tip of the rostrum, which is a part of the head, and not properly an "appendage."

Anong the Edriophthalma or sessile-eyed Crustacea, the Isopoda may in general be characterized as follows: Body depressed rather than compressed; respiration carried on by means of the pleopods, of which the last pair only are modified into uropods. 
The body is said to be depressed, or flattened from above, in distinction from the form usually seen in the Amphipoda, where it is in general flattened from side to side. An important exception to the ordinary mode of respiration occur's in the Lunaide, as has alleady been mentioned. In this family respiration takes place in two lateral eavities, situated beneath the integument of a large cephalothoracic shield, covering the hearl and first thoracic segment. In general, as the name of the order indicates, the legs are similar in structure and function throughont, as in the "sow-bug," but may differ considerably, as in the Arcturide, the Munnopside, and the Tanaide.

The arrangement of the families in the present paper can only be regarded as tentative, and no higher grouping will be attempted further that to indicate briefly the relationships of a few of the families to each other.

The Oniscidce inay, on account of their aërial respiration, be regarded as standing quite distinet from the remaining families, and should, perhaps, be further divided as proposed by Kinahan. As they do not, how. ever. come within the proper scope of this article, I have not attempted to subdivide the family. The Bopyridce have been placed near the Oniscidce in deference to the opinions of Dr. Fritz Miiller. Having made no study of this family myself I do not express any opinion as to the propriety of separating it so widely from the Cymothoidce, with which it has usually been associated. The Asellide and Munnopside are closely allied to each other. The Idotcides and Arcturide form a group distinguished especially by their opereuliform uropods. The above families correspond nearly with the "marcheurs" or walling Isopoda of Edwards, and more nearly with the "gehende Asseln" of Miiller. They usually have the antennulæ much less developed than the antennæ, and the uropods terminal or inferior, that is, attached to the end of the last segment, or in the last two families to its inferior surface.

The Sphceromidce and Limnoriidce are elosely allied, and perhaps onght hardly to be kept separate as families. The Cirolanida, AEgidce, and Cymothoida form another group embracing a wide dirersity of forms, from the active predatory Cirolana to the sedentary and distorted Livoneer, and yet apparently connected by easy gradations. The remaining fumilies are generally regarded as aberrant, and form the "Isopoda aberrantia" of Bate and Westwood. They do not present any very evident relationships with the preceding. Of these the Anthurida have usually been associated with the Idoteidce or the Arcturida, or with both. Except an elongated form, however, they do not appear to have much in common with either of these families. According to Dohrn's olsservations they are related to the Gnathiidce in the structure of the incubatory pouch. The Gnathiide have the hear united with the first thoracic segment, as in the Tanaide, but this last family is widlely separated from the others, and doubtless ought to be regarded as forming a distinct suborder, according to the views of Dr. Fritz Müller. 
The arrangement of the families adopted, and to a certain extent their aftinities, are indicated in the subjoined table, in which, however, as throughont the article, special reference is had to the representatives of the order in New England waters, extralimital species, genera, and even higher gromps, Apseudes and the Serolids, for example, being disregarded. The arrangement will be seen to considerably resemble that of Dr. Fritz Miiller. I have placed the Tanaides at the other end of the order, partly, however, from the necessity of a lineal arrangement.

\section{SYNOPTICAL TABLE OF FAMILIES.}

I. Respiration pleonal ; legs not furnished with a ehelate hand.

1. Legs in seven pairs.

a Antennulie small or rudimentary; antennæ longer, often mueh elongated.

† Uropods terminal, sometimes rudimentary, rami mostly styliform.

Legs ambulatory; antennnlie rudimentary; respiration aerial.

I. ONISCID As, p. 305

Legs prehensile; sexes very unlike; adult forms degenerate; parasitio ...................................... BI. BOPYRID 1 , p. 311

Legs ambulatory or prehensile; segments of pleon united; antennæe with a multiarticulate flagellum........................ III. AsELlid N, p. 312

Last three pairs of legs natatory; segments of pleon united; antennæ with a multiartieulate flagellum.................... IV. MUNNOPSIDE, p. 328 † Uropods inferior, operculiform.

Legs prehensile or ambulatory, not ciliated............ V. IDOTEID $\mathrm{E}$, p. 335

First four pairs of legs eiliated; last three pairs ambulatory.

VI. ArCturide, p. 361

$b$ Antennulx and antennæe subequal; body not elongated.

+ Uropods lateral, with one ramus obsolete or subrudimentary.

Antennulie and antenna well developed; pleon of two segments; uropods with one movable ramus .................... VII. SPHÆROMID., p. 367

Antennula and antenno short; pleon of six segments; onter ramus of uro-

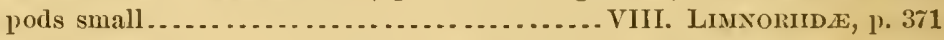

† Uropods lateral, distinetly biramous; rami mostly lamelliform.

Mouth caruassial; legs not ancoral; antemnula exposed in fiont; pleopods ciliated................................. IX. Cirolanid . p. 376

Mouth snetorial; first three pairs of legs ancoral; antennulio exposed in front .......................................... 太. ÆGIDE, p. 382

Mouth snetorial ; legs all ancoral ; antennula coneealed at base by tho projecting front; pleopods naked.................. XI. Cruotionds, p. 390

c Antenmula and antemnæ subequal, or antennula nuch the largest in the niales; body eylindrieal, elougated.

† Uropods lateral and superior.

Legs amlulatory or prehensile................... XII. Antuurid 2, p. 396

2. Legs in the adult in six, apparently only five, pairs.

Five pairs of legs ambulatory; anteunulio and antenna subequal.

XIII. Grathind $\mathbb{x}$, p. 408

II. Respiration eeplalothoraeic ; first pair of legs terminated by a chelate hand.

Leges ambulatory and prehensile; head nnited with the first thoracic segment; antennular flagellum single..............XIV. TANaIDE, P. 413 


\section{I.-ONISCID AE.}

Antennulæ rudimentary; legs ambulatory; pleon of six distinct iegments, of which the last is small; mandibles without palpi ; uropods terminal.*

This large and important group of Isopoda being terrestrial in habit, only a few species are mentioned in this paper. They inhabit moist situations, and are commonly known as "sow-bugs," "pill-bugs," "wood-lice," \&c. Several species may often be found under an old board or pile of rubbish. The genus Ligia Fabr. inhabits sea-shores, above tide-lerel, and a few other genera are found under heaps of seaweed, or burrowing in the sand along the shore. Three such species, belonging to as many genera, are here deseribed and figured, but are less fully treated of than the marine species that follow in the other families. Other species, especially of the genus Porcellio, may be found in similar situations.

The family may be at once recognized by the apparent possession of only a single pair of antennæ. These are the antennæ properly so ealled, the antennulæ being minute and rudimentary. This is generally regarded as a character indicating a high degree of development, and causes them to somewhat resemble externally some of the shorter myriopoda, which, like other insects, have but a single pair of antennary organs. The maxillipeds are large and opereuliform in this family, with short and few-jointed palpi. The mandibles are destitute of palpi.

The legs are rather weak and fitted only for walking, and usually more or less concealed by the projecting epimeral regions of the thoracic segments. The pleon, in our species, has its segments distinct and decreasing rapidly in size to the last, which bears the more or less exserted uropods. These organs may not, however, project beyond the general outline of the pleon, as they searcely do in Actoniscus, while in Armadillo they assist in forming the very regular ontline of that part of the body, which closes against the head when those animals, as is their habit, roll themselves into a ball on being alarmed.

This family is placed by Bate and Westwood in a separate "division," the "AEro-spirantia," on account of their aërial respiration. The air, howerer, requires to be saturated with moisture, and in some of the genera the respiration is, in part at least, aquatic. On this subject the reader is referred to the publications of Duvernoy and Lereboullet and of Nicholas Wagner.

Philoscia Latreille.

Pliloscia Latreille, Hist. nat. des Crust. et des Ins., tomo vii, p. 43, "1804."

Head rounded in front, not lobed; antennæ with its segments ejlindrieal, flagellum three-jointed; pleon suddenly narrower than the thorax; uropods exserted, basal segment broad, rami elongate.

* The above diagnosis would not includo tho genera Tylus Latreillo nor Helleria Ebner, whieh perhaps ought not to be regarded as belonging to this family, although closely allied to it. 
This genus may be recognized among our Oniscida by the rounded head without lobes, and the conspicuously narrowed pleon. Only a single species is as yet known from New England.

Philoscia vittata Say.

Philoscia rittata Say, Jour. Acad. Nat. Sci., vol. i, p. 429, 1818.

Dekay, Zool. New York, Crust., p. 50, 1844.

White, List Crust. Brit. Mus., p. 99, 1847.

Harger, This Report, part i, p. 569 (275), 1874; Proc. U. S. Nat. Mus., 1879, vol. ii, p. 157, 1879.

\section{Plate I, Fig. 1.}

This species may be recognized, among our terrestrial Isopoda, by the absence of the usual antero-lateral processes on the head, in front of the eyes, and by the sudden contraction of the body at the base of the abdomen or pleon.

Body oval, smooth; about twice as long as broad; head nearly twice as broad as long; eyes large, occupying the antero-lateral regions of the head. The antennulæ are minute and concealed from above. Antennie minutely hirsute, especially on the last three, or flagellar, seg. ments, inserted below the inner margin of the eyes; first segment short; second about twice as long as the first; third equal in length to the seeond, clavate; fourth longer eylindrical; fifth longest, slender, eylindrical, straight; flagellum slender, three-jointed, longer than the fifth or last pedumenlar segment; first flagellar segment about one-half longer than the second; third longer than the second, tapering, tipped with a short transparent filament.

The first thoracic segment is longer than the following ones, which are of about equal length. The anterior angles of the first thoracie segment are somewhat produced at the sides around the head; the posterior angles are broadly rounded. The second and third segments have their posterior angles less broadly rounded, but not at all prodnced backward. In the fourth segment this angle is searcely produced, but in the fifth, and still more in the sixth and seventh, it becomes produced and acute. The legs increase in size and length from the first to the seventh pair, and are well armed with spines, especially upon the inferior surfaces of the meral, carpal, and propodal segments. The spines on the latter seg. ment are, however, much smaller than those on the merus and carpus.

The pleon is at the base about two-thirds as wideas the seventh thoracic segment. In the first two segments of the pleon the coxæ, or lateral lamelli, are short, small, and nearly concealed by the seventh thoraeic segment, but in the third, fourth, and fifth segments they are evident and aeute but not large. The sixth segment is aente but not prolonged behind, and extends beyond the end of the basal segment of the uropod, which is broad and bears the two rami nearly on the same transverse line. The outer ramus, seen from above, is narrowly and obliquely lanceolate in outline, tapering to the tip, and surpasses by less than half its length the more slender, styliform inner ramus. The uropods, the legs and antennæ, and the serments of the nleon alon or their maroin are vert minutelv hirsute. 
The color of these animals is dull and somewhat variable, usually brownish or fuscons, with lighter margins and two broad dorsal vittæ. Length $\mathrm{S}^{\mathrm{mm}}$, breadth $4^{\mathrm{mm}}$.

This species has been found under rubbish and stones from Great Egg Harbor,! N. .J., to Barnstable, ! Mass. All the specimens that I have seen have been from the const, although Say states that it is "very common under stones, wood, \&c., in moist situations."

Specimens cxamincl.

\begin{tabular}{|c|c|c|c|c|c|c|}
\hline 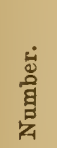 & Locality. & Habitat. & $\begin{array}{l}\text { When col- } \\
\text { lected. }\end{array}$ & Received from- & 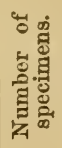 & $\begin{array}{l}\text { Dry. } \\
\text { Alc. }\end{array}$ \\
\hline 1222 & $\begin{array}{l}\text { Somers and Beeslev's Points, } \\
\text { N.J. }\end{array}$ & Shore........... &,-- 1871 & $\begin{array}{l}\text { A. E. Verrill and } \\
\text { S. I. Smith....... }\end{array}$ & 25 & Ale. \\
\hline $\begin{array}{l}1911 \\
2146\end{array}$ & $\begin{array}{l}\text { Stony Creok, Conn } \\
\text { Vineyard Sound, Mass........ }\end{array}$ & 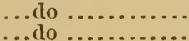 & ….....187i & $\begin{array}{l}\text { A. E. Verrill ........ } \\
\text { U. S. Fish Com.... }\end{array}$ & 8 & Alc. \\
\hline 1910 & Barnstable, Mass ........... & ....do $\ldots . . . . .$. & Ang. 30,1875 & . S. & 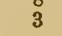 & Alc. \\
\hline
\end{tabular}

Scyphacella Smith.

Scyphacella, Smith, This Report, part i, p. 567 (273), 1874.

Antenna composed of eight distinct segments, with a geniculation at the articulation of the fourth with the fifth segment; terminal portion, or flagellum, composed of three closely articulated segments besides a minute apical one; mandibles slender; exposed portion of the maxillipeds formed of only two segments.

The genus Scyphacella was founded by Professor S. I. Smith, in part I of this Report, for the reception of the following species, the only one yet known. In regard to the relations of the present genus with Scyphax Dana* Professor Smith says: "This genus differs from Scyphax most notably in the form of the maxillipeds, which in Scyphax have the ter. minal segment broad and serrately lobed, while in our genus it is elongated, tapering, and has entire margins. In Scyphax, also, the posterior pair of thoracic legs are much smaller than the others, and weak; the last segment of the abdomen is trumcated at the apex, and the articulations between the segments of the terminal portion of the antenna, are much more complete than in our species. The general form and appearance of the genera are the same, and the known species agree remarkably in habits, the Scyphax, according to Dana, occurring on the beach of Parua Harbor, New Zealand, and found in the sand by turning it over for the depth of a few inches."

Scyphacella arenicola Smith.

Scyphacella arenicola Smith, This Report, part i, p. 568 (274), 1874.

Verrill, This Report, part i, p. 337 (43), 1874.

Harger, Proc. U. S. Nat. Mus., 1879, vol. ii, p. 157, 1879.

Plate I, Fig. 2.

The small size, nearly white color, and peculiarly roughened surface of this Isopod will in general serve for its recognition, and the presence

${ }^{*}$ U. S. Exploring Expedition, Crustacea, p. 733, pl. 48, fig. 5 . 
of eyes will further distinguish it from Platyarthrus, which is often found inhabiting ants' nests, but would hardly be likely to occur in the sand of the beach.

Body elliptical, pleon not abruptly narrower than the thorax, dorsal surface roughened throughont with small depressed tubercles each giving rise to a minute spinule. Head transverse, not lobed; eyes prominent, round; antenne longer than the breadth of the body; with the first and second segments short; third, fourth, and fifth suceessively longer and of less diameter; flagellum shorter than the fifth segment, composed of three closely articulaterl, suecessively smaller segments, and a very short somewhat spiniform but obtuse terminal one; all the segments, except the minute terminal one, beset with small scattered spinules.

First thoracic segment scarcely embracing the head at the sides; second, third, and fourth segments each about as long as the first, but increasing in breadth; fifth, sixth, and seventh diminishing in length and the last two also in breadth. Posterior lateral angles of the first three segments not at all produced, hardly perceptibly produced in the fourth segment; fifth, sixth, and seventh with the angles increasingly produced but not acute. Legs increasing somewhat in size posteriorly, armed, especially on the inferior surface of the meral, carpal, and propodal seg. ments, with short stout spines.

Segments of the pleon with the coxre but little developed. Terminal segment slightly rounded at the end, not attaining the end of the basal segment of the uropods, which are robust, with the basal segment spinulose, tapering to the base of the short, stout, outer ramus, and bearing the more slender inner ramus much nearer its base. The inner ramus is actually longer than the onter, but being inserted much lower down does not attain the tip of the outer ramus; both are tipped with setæ.

"Color, in hife, nearly white, with chalky white spots, and scattered, blackish dots arranged irregularly. Eyes black." Length $3.4^{\mathrm{mm}}$.

This species was "found at Somers and Beesley's Points, on Great Egg Harbor!, New Jersey, in April, 1871, burrowing in the sand of the beaches, just above ordinary high-water mark, in eompany with several species of Staphylinida," and has also since been found by Professor Smith at Nobska Beach, Vineyard Sound!, Mass., in 1871, and by Mr. V. N. Edwards, on the beach at Nantucket Island!, December 6, 1877. It will doubtless be found at other points along the coast and toward the south.

Specimens examined.

\begin{tabular}{|c|c|c|c|c|c|c|}
\hline 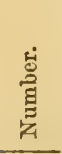 & Locality. & IIabitat. & $\begin{array}{l}\text { When col- } \\
\text { lected. }\end{array}$ & Reccived from- & 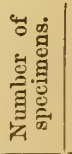 & $\begin{array}{l}\text { Dry. } \\
\text { Ale. }\end{array}$ \\
\hline 2136 & $\begin{array}{l}\text { Great Egg IIarbor, N. J..... } \\
\text { Nobska Weach, Mass ........ } \\
\text { Nantucket ................. }\end{array}$ & \begin{tabular}{l} 
Sandly beach ..... \\
\hdashline$\ldots$ do $\ldots . . . . . .$. \\
$\cdots$
\end{tabular} & $\begin{array}{l}\text { Apr. }-1871 \\
\text { Aug. 18, 1S71 } \\
\text { Dec. 6,1877 }\end{array}$ & $\begin{array}{l}\text { S. I. Smith ........... } \\
\dddot{\nabla} . \grave{N} \text {. Edwards ........ }\end{array}$ & $\begin{array}{l}2 \\
1\end{array}$ & $\begin{array}{l}\text { Alc. } \\
\text { Alc. } \\
\text { Alc. }\end{array}$ \\
\hline
\end{tabular}


Actoniscus Harger.

Actoniscus Harger, Am. Jour. Sci., III, vol. xv, p. 373, 1878.

Eyes small; antennæ geniculate at the third and fifth segments; flagellum four-jointed; terminal segments of maxillipeds lamelliform, lobed; legs all alike; basal segment of uropods dilated and simulating the coxæ of the preceding segments of the pleon; rami both styliform.

This genus resembles Actccia Dana* MSS., considered as the young of Scyphax ornatus, and found with it on the beach at New Zealand. Professor Kinahan, $\dagger$ on the other hand, regarded the genus as indicating a distinct family. The present genus differs from the description and figures of Professor Dana as follows: The flagellum of the antennre consists of only four distinct segments instead of about six; the terminal segment of the maxillipeds is less distinctly lobed; the inner ramus of the uropods surpasses the outer, instead of falling far short of it; the outer ramus is styliform instead of being enlarged and subequal to the produced and enlarged outer angle of the basal segment.

\section{Actoniscus ellipticus Harger.}

Actoniscus ellipticus Harger, Am. Jour. Sci., III, vol. xv, p. 373, 1878; Proc. U. S. Nat. Mus., 1879, vol. ii, p. 157, 1879.

Plate I, Fig. 3.

This species may be at once recognized by the pleon, which appears to have four pairs of coxæ produced at the sides instead of three, as in Oniscus and other genera of this family. The last pair are, however, the basal segments of the caudal stylets, which are of peculiar form in this gemus.

The body is oval in outline. The head appears triangular as seen from above, and.is angularly produced in a median lobe, but the lateral lobes are also large and divergent, and broadly rounded. The eyes are small, oval, black, and prominent. They are situated at the sides of the median triangular part of the head, and at the base of the lateral lobes. The antennulx are minute and rudimentary. The antenne have the basal segment short; the sceond enlarged distally, especially on the inner side; the third forming an angle with the second, and clarate; the fourth flattened-cylindrical, longer than the third; fifth longest, slender, bent at base and forming an angle with the fourth; flagellum shorter than the last peduneular segment, tipped with setæ and composed of four segments, of which the second and third are equal and longer than the first, while the last is the shortest, and presents indications of another minute rudimentary terminal segment. The maxillipeds have the basal segment nearly twice as long as broad; the terminal segment elongate triangular, ciliated and somewhat lobed near the tip. 
The first thoracic segment is excavated in front for the head, admitting it abont to the eyes. The next five segments are each a little longer than the first, but the last thoracic segment is the shortest. The first segment is dilated at the sides to abont twice its length on the median line. The second, and in an increasing degree the succeeding segments are produced backward at the sides. The legs are rather small and weak and of nearly equal size throughout.

The first two segments of the pleon hare their lateral processes, or coxr, obsolete as usual in the family, but the third, fourth, and fifth segments are prodnced laterally into broad plates, which are close together, and, at their extremities, continue the regular oral outline of the body with scarcely a perceptible break between the thorax and the pleon. This ontline is further continued by the expanded basal segments of the uropods, which are eren larger than the adjacent coxæ of the fifth segment. At the extremity of the pleon both pairs of rami are visible, the inner springing from near the base of the basal segments below, the outer from a notch near the milllle of the immer margin of the basal segment. The rami are tipped with setæ, and the inner just surpass the outer, which, in trurn, surpass the produced portion of the basal segments.

Length $4^{\mathrm{mm}}$, breadth $2^{\mathrm{mm}}$. Color in life slaty gray.

This species was collected by Professor Verrill, at Savin Rock, near New Haren!, and also at Stony Creek!, Long Island Sound, in company with Philoscia vittata Say.

Specimens examined.

\begin{tabular}{|c|c|c|c|c|c|c|}
\hline 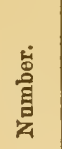 & Locality. & Habitat. & $\begin{array}{l}\text { When col- } \\
\text { lected. }\end{array}$ & Received from- & 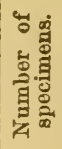 & $\begin{array}{l}\text { Dry. } \\
\text { Alc. }\end{array}$ \\
\hline $\begin{array}{l}2137 \\
2138\end{array}$ & $\begin{array}{l}\text { Savin Rock, Conn... } \\
\text { Stony Creek, Conn.. }\end{array}$ & $\begin{array}{l}\text { Shore................ } \\
\text {...do }\end{array}$ & 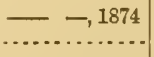 & $\begin{array}{c}\text { A.E. Verrill.......... } \\
\text {.....do }\end{array}$ & $\begin{array}{l}2 \\
1\end{array}$ & $\begin{array}{l}\text { Alc. } \\
\text { Alc. }\end{array}$ \\
\hline
\end{tabular}

The genus Ligia Fabrieius* is recorded by Gonld $\dagger$ from the timbers of a wharf, probably in Boston, and by Dr. Leidy, $\ddagger$ with some donbt, from Point Judith, R. I., and the characteristics of the genus are therefore here brietly inserted, as follows:

Antemne with a multiarticulate flagellum; basal segment of uropods exserted bearing two elongated eylindrical rumi.

They are found usually in rocky places and under stones just above high-water mark. They are common on our southern coast, and are probably, at least occasionally, transported by accident within our limits. I have seen no specimens from nearer than Fort Macon, N. C.

* Suppl. Ent. Syst., p. 296, 1798.

t Invert. Mass., p. 337, 1841.

$\ddagger$ Jour. Acad. Nat. Sci., II, vol. iii, p. 150, 1855. 


\section{II.-BOPYRID $Æ$.}

This family has not been studied, and only a list of the species, furnished by Professor S. I. Smith, is included. They are parasitic on Crustacea, and at maturity, the females especially, are generally much distorted and degenerate, often losing a great proportion of their appendages. The males are much smaller than the females, and of a more normal form, and they and the young forms must therefore be relied upon to indicate the aftinities of this group to the rest of the order. Accorling to Dr. Fritz Miiller these forms indicate a relationship to the Oniscidce, and especially to the genus Ligia, and in deference to his authority I have inserted them at this place.

\section{Cepon distortus Leidy.}

Cepon distortus Leidy, Jour. Aead. Nat. Sei., II, vol. iii, p. 150, pl. xi, figs. 26-32, 1855.

Harger, This Report, part i, p. 573 (279), 1874; Proe. U. S. Nat. Mus., 1879, vol. ii, p. 157, 1879.

Leidya distorta Cornalia and Paneeri, Mem. R. Acead. Sei. Torino, II, tom. xix, p. 114, 1861.

"From the branchial cavity of Gelasimus pugilator, Atlantic City, New Jersey." (Leidy.)

Gyge Hippolytes Bate and Westwood (Kröyer).

Bopyrus Hippolytes Kröyer, Grönlands Amfipoder, p. 306 (78), pl. iv, fig. 22, 1838; Monog. Fremst. Sliggten Hippolyte's nordiske Arter, p. 262, 1842 ; Voy. en Scand., Crust., pl. xxviii, fig. 2, 1849.

Edwards, Hist. nat. des Crust., iii, p. 28:3, 1840.

Stimpson, Proe. Aead. Nat. Sei. Philadelphia, 1863, p. 140.

Gyge Hippolytes Bate and Westwood, Brit. Sess. Crust., vol. ii, p. 230,1868.

Buchholz, Z weite deutsehe Nordpolfahrt, p. 286, 1874.

Metzger, Nordseefahrt der Pomm., p. 286, 1875.

Miers, Ann. Mag. Nat. Hist., IV, vol. xx, p. 64, (14), 1877.

Smith in Harger, Proc. U. S. Nat. Mus., 1879, vol. ii, p. 157, 1879.

Massachusetts Bay !, off Salem, on Hippolyte spinus, 30 fathoms, sand and mud, August 4, 1S77; on H. Fabricii, 22 fitthoms, grarel, August 4, 1877; on $I$. sccurifrons, 90 fathoms, soft mud, August 14, 1877. Casco Bay !, on $\Pi$. polceris and $\Pi$. pusiola, 1873. Bay of Fundy !, on $H$. spinus and H. pusiola, 1868, 1872. Off Halifax, Nova Scotia, 43 fithoms, Sep. tember 27, 1877. Gulf of Maine !, 40 miles east of Cape Aun, Massachusetts, on $\mathbb{E}$. securifrons, 160 fathoms, soft mud, Angust 19, 1877; also newr Cashe's Ledge, on HI. spina, 27 and 40 fathoms, rocks and gravel.

East side of Smith's Strait, north latitude $78030^{\prime}$ (Stimpson). "Discovery Bay," north latitude 810 44', Greenland (Miers). British Islands (Bate \& Westwood). Scandinavian coasts (Kröyer et al.). Spitzber. gen (Kröyer). 
Phryxus abdominalis Liljoborg (Kŕ̈̈yer).

Bopyrus abdominalis Kröyer, Nat. Tidsskr., vol. ii, pp. 102, 289, pls. i, ii, 1840; Monog. Fremst. Slægten Hippolyte's nordiske Arter, p. 263, 1842; Voy. en Scand., Crust., pI. xxix, fig. 1, 1849.

Phryxus Hippolytes Rathke, Fauna Norwegens, p. 40, pl. ii, figs. 1-10, 1843.

Phryxus abdominalis Liljeborg, GEfvers, liongl. Vet.-Akad. Fürh., ix, p. 11, 1852.

Steenstrnp and Lütken, Vidensk. Meddelelser, 1861, p. 275 (9).

Bato and Westwood, Brit. Sessile-eyed Crust., vol. ii, p. 234, 1868.

Norman, Rep. Brit. Assoc., 1868, p. 288, 1869; Proc. Royal Soc., London, vol. $\mathrm{xxv}$, 1). 209, 1876.

Buchholz, Zweite dentsche Nordpolfahrt, p. 287, 1874.

Metzger, Nordseefahrt der Poinm., p. 286, 1875.

Miers, Ann. Mag. Nat. Hist., IV, vol. xx, 1. 65 (15), 1877.

Smith in Harger, Proc. U. S. Nat. Mus., 1879, vol. ii, p. 158, 1879.

Massachnsetts Bay!, off Salem, on Pandalus borealis, Hippolyte spinus, and $I$. securifrons, 48-90 fathoms, soft mud, Angust 13 and 14, 1877 ; also, on Pandalus Montagui, 35 fathoms, mud and clay nodules, August 10, 1877. Cashe's Ledge !, Gulf of Maine, on Hippolyte pusiola, 27 and 39 fathoms, rocky, September 5, 1874. Halifax!, Nova Scotia, on Hippolyte pusiola, 18 fathoms, fine sand, September 4, 1877; also, on H. spinus. About 30 miles south of Halifax !, on Hippolyte securifrons, 100 fathoms, fine sand, September 6, 1877.

Grinnell Land, in north latitude $79 \circ 29^{\prime}$; and "Discovery Bay," north. latitude $81044^{\prime}$ (Miers). Greenland (Kröyer et $a l$. ). British Islands (Norman et al.). Seandinavian coast! (Liljeborg et al.). Spitzbergen (Miers).

\section{Dajus Mysidis Kröyer.}

Dajus Mysidis Kröyer, Voy. en Scand., Crust., pl. xxviii, fig. 1, 1849.

Lïtken, Crustacea of Greenland, p. 150, 1875.

? G. O. Sars, Arch. Math. Nat., B. ii, p. 354 [254], 1877 ("D. Mysidis?").

Smith in Harger, Proc. U. S. Nat. Mus., 1879, vol. ii, p. 158, 1879.

Bopyrus Mysidum Packard, Mem. Bost. Soc. Nat. Hist., vol. i, p. 295, pl. viii, fig. 5, 1867.

9 Leptophryxus Mysidis Buchholz, Zweite Deutsche Nordpolfahrt, p. 283, pl. ii, fig. $2,1874$.

Labrador (Packard). Greenland (Kröyer, Buchholz). ? Off west coast of Norway (G. O. Sars).

Bopyrus, species.

Bopyrus Leidy, Proc. Acad. Nat. Sci., 1879, pt. ii, p. 198, 1879.

? Smith, Trans. Conn. Acad., vol. v, p. 37, 1879.

A species of Bopyrus is mentioned by Dr. Leidy as "a parasite of the shrimp, Palcmonetes vulgaris," occuring in the summer of 1879 , at Atlantic City, N. J.

\section{III.-ASELLID Aહ.}

Antennæe elongated with a multiarticulate flagellum; legs ambulatory or prehensile, not strictly natatory ; pleon consolidated into a scutiform segment, bearing terminal uropods, which may be nearly obsolete.

This family is represented on our coast by four species belonging to 
three genera, and a species of another genus (Asellus communis Say) is common in the fresh-water ponds and streams of New England. The geuns Limnoria Leach has been regarded by modern writers as belonging to this family, but will be found in the present artiele in the Limnoriide (p. 79). There remain then to be considered the genera Asellus Geoffroy,* Jora Leach, Janira Leach, and Munna Kröyer, which, as represented in our waters, may be further characterized as follows :

The head is well developed, and in Munna is of large size; the borly is usually depressed or but slightly arched, except that the pleon is vaulted in Munna. The eyes are present in our species though not throughout the family. The antennulæ beyond the basal segment are slender and are always much shorter than the antennæ, which are elongated and composed of a five-jointed pedunele and a slender multiarticulate flagellum. The first three pedumcular segments are short; the last two elongated. The parts of the mouth are protected below by a pair of maxillipeds with large external lamellæ and five-jointed palpi. Within the maxillipeds are two pairs of maxillæ of the ordinary form; the outer or second pair delicate and three-lobed at the tip; the inner lobe being formed by the projecting basal segment, while the two outer lobes are articulated; all three lobes are provided with curved spiniform setæ. The inner, or first, pair of maxillæ present two narrow lobes; the outer lobe broader and more robust than the inner, and armed with robust curved spines, while the inner is tipped with much weaker setæ. The mandibles (see fig. $12 b, \mathrm{pl}$. III) are provided with one or two acute dentigerous lamellæ $(d)$ at the tip, usually a comb of setæ and a strong molar process below $(m)$, and a triarticulate palpus $(p)$. This latter organ is, however, wanting in the genus Mancasellus Hargert from the Great Lakes and other fresh-water localities of North America.

The seven segments of the thorax are distinct from the head and from each other, and differ but little in general appearance throughout. The legs are mostly slender aud elongated, except that the first pair may be more robust and better fitted for prehension. In our marine species the dactylus, at least behind the first pair of legs, is short and armed with two small claws or ungues, while the propodus is capable of considerable flexion on the carpus.

The segments of the pleon are united into a single piece, which is sentiform above, flattened or but little arched, except in MLunna, and bears, at or near the tip, the biramous uropods, which are, howerer, nearly obsolete in MIunna. The pleon often shows more or less trace of its compound character in imperfect transverse sutures on the dorsal surface near the base, and below it is excavated for the pleopods, the posterior pairs of which are delicate and branchial in their nature, while the anterior pairs

* "Hist. des Ins. t. ii" (Edw.). For information in regard to the common European form of this genus the reader should consult the admirable work of G.O. Sars, Hist. nat. des Crust. d'eau donce de Norvège.

†Am. Jour. Sci., III. vol. xi, p. 304, 1876. See, also, op. cit., vol. vii, p. 601, 1874, and This Report, part ii, p. 659, pl. i. fig. 3,1874 . 
are varionsly modified in the different genera and in the sexes, so that much confusion has been introduced into the family by mistaking sexual for generic modifications of these organs. The branchial pleopods are usually proteeted by a thickened anterior pair, which, especially in the females of our marine species, may be consolidated into a single opercular plate, as will be further described. The incubatory pouch in the females does not appear to extend farther back than the fourth thoracic segment, and it may be confined to the second, third, and fourth segments.

In the last-mentioned, as well as in many other characters, this family is closely related to the next, and perhaps the Munnopside may yet require to be united with it. Our species of the two families are at once distinguished by the last three pairs of legs, which are ambulatory in the Asellide and natatory in the Munnopside. Our Iunnopsidce are, moreover, like the other known species of that family, destitute of eyes, while the marine Asellide have evident or conspicuous eyes, but the fresh-water genus Cocidotea Packard* is blind, as are also certain foreign species referred to the present family. The relations of the Asellide with families other than the IIunnopsida are less evident. They were associated by Professor Danat with his Armadillide and Oniscidce to form his subtribe Oniscoidea, and, Limnoria being excluded, the group appears to be a natural one.

Asellus communis Say, confined to fresh waters, and the only known New England representative of the genus, was described and figured by the present author, in Professor S. I. Smith's "Crustacea of the Fresh Waters of the United States," published in part II of this report (page 657, plate I, figure 4). Our marine representatives of the family may be most easily recognized by the consoliclated pleon, ambulatory or prehensile legs, none of them natatory, and the slender, elougate antennæ. The genera may be distinguished by means of the following table:

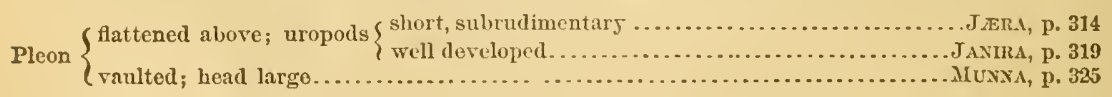

Jæra Leach.

Jera Leach, Ed. Encyc., vol. vii, p. "434" (Am. ed., p. 273), "1813-14."

Antennulx short, few-jointed; antennæ moderately elongated; mandibles with palpi; first pair of legs similar to the following pairs; lateral margins of the thoracic segments projecting over the bases of the legs; uropods short, rami subrudimentary; pleon protected below in the females by a subcircular plate.

The short uropods and projecting lateral margins of the thoracic segments serve to distinguish this genus from its allies, and other characters of generic importance could doubtless be drawn from the pleon and its appendages, as well as from other parts of the structure, but, as it 
is represented in our limits by a single species, $\mathrm{I}$ have not been able to separate the generic from the specific characters with confidence, and have therefore described the species without attempting it.

Jæra albifrons Leach.

"Oniscus albifrons Montague MSS." (Leach).

Jera albifrons Leach, Ed. Encyc., vol. vii, p. "434" (Am. ed., p. 273), "1813-14";

Trans. Linı. Soc., vol. xi, p. 373, 1815.

Samouelle, Ent. Comp., p. 110, 1819.

Desmarest, Dict. Sci. nat., tome xxviii, p. 381, 1823; Consid. Crust., p. 316, 1825 .

Latreille, Règne Anim., tome iv, p. 141, 1829.

Edwards, Annot. de Lamarck, tome v, p. 267, 1838; Hist. nat. des Crust., tome iii, p. 150, 1840; Regne Anim., Crust., p. 204, 1849.

Moore, Charlesworth's Mag. Nat. Hist., n. s., vol. iii, p. 294, 1839.

Thompson, Aun. Mag. Nat. Hist., vol. xx, p. 245, 1847.

White, List Crust. Brit. Mus., p. 97, 1847 ; Brit. Crust. Brit. Mus., p. 69, 1850 ; Pop. Hist. Brit. Crust., p. 231, 1857.

Lilljeborg, Öfvers. Vet-Akad. Förh., Arg. viii, p. 23; 1851; ibid., Arg. ix. p. 11, 1852.

Gosse, Man. Mar. Zool., vol. i, p. 136, fig. 243, 1855.

M. Sars, Christ. Viı. Selsk. Forh., 1858, p. 153, 1859.

Bate, Rep. Brit. Assoc., 1860, p. 225, 1861.

G. O. Sars, Reise ved Kyst. af Christ., p. (29), 1866 ; Christ. Vid. Selsk. Forh., 1871, p. 27\%, 1872.

Norman, Rep. Brit. Assoc., 1866, p. 197, 1867 ; ibid, 1868, p. 288, 1869.

Bate and Westwood, Brit. Sess. Crust., vol. ii, p. 317, figure, 1868.

Metzger, J. B. Naturhist. Ges. Hanuover, xx, p. 32, 1871; Nordseefahrt der Pomm., 1872-'3, p. 285, 1875.

Parfitt, Trans. Devon. Assoc., 1873, p. (18), "1873."

Stebbing, Jour. Linn. Soc., Zool., vol. xii, p.149, 1874 ; Ann. Mag. Nat. Hist., IV, vol. xvii, p. 79, pl. v, figs. 5-6, 1876 ; Trans. Devou. Assoc., 1879 p. (7), $18 \% 9$.

Meinert, Crust. Isop. Amph. Dec. Dan., p. 80, “1877." (Iaira.)

Harger, Proc. U. S. Nat. Mus., 1879, vol. ii, p. 158, 1879.

Jara Kröyeri Zaddach, Syn. Crust. Pruss. Prod., p. 11, "1844" (J. Kröyeri Edwards?).

Jara baltica Fried. Müller, Arch. Naturg., Jahrg. xiv, p. 63, pl. iv, fig. 29, 1848. Jæra copiosa Stimpson, Mar. Inv. G. Manan, p. 40, pl. iii, fig. 29, 1853.

Packard, Canad. Nat. and Geol., vol. viii, 1. 419, 1863.

Verrill, Am. Jour. Sci., III, vol. vii, p. 131, 1874; Proc. Amer. Assoc., 1873, p. 369, 1874 ; This Report, part i, p. 315 (21), 1874.

Harger, This Report, part i, 1). 571 (27\%), 1874.

Jera nivalis Packard, Mem. Bost. Soc. Nat. Hist., vol. i, p. 296, 1867. (J. niralis Kröyer ?.)

Asellus Grönlandicus Packard, loc. cit. (not of Kröycr).

Jara marina Möbius, Wirbollos. Thiere der Ostseo, p. 122, 1873; Ann. Mag.

Nat. Hist., IV, rol. xii, p. 85, 1873. (J. marina labricius ?.)

Jara maculata Parfitt, Trans. Devon. Assoc., 1873, p. “253” (18), “1873.”

Stebbing, Trans. Devon. Assoc., 1879, p. (7) 1879, (albifrons).

Plate I, Figs. 4-8.

This species is at once distinguished from the other marine Isopoda of our coast by the short uropods, arising from a notch in the end of the 
subcircular pleon. From the terrestrial forms, which it somewhat resembles, and in company with which it may sometimes be found, the above-mentioned character, joined with the multiarticulate flagellum of the antennæ, will serve to distinguish it.

The body is oval and flattened, a little more than twice as long as broad. The head is transverse, broadly excarated on each side over the bases of the antennulæ, sparingly ciliated on the lateral margins, with short seattered spine-like unequal cilia or setæ, which occur in a similar manner along the entire borders of the animal behind the front margin of the head. The ejes are prominent and black, sitmated near the posterior margin of the lateral regions of the head. The antennula are five-jointed, and do not surpass the fourth segment of the antennæ; the basal segment is large and separated from its fellow of the opposite side by about twice its diameter; the second segment is about as long as the first, but of much less than half its diameter; third segment shorter than the second, fourth still shorter, fifth tapering, tipped with setæ. The first three segments of the antennæ are short; the fourth is robust, and about as long as the first three together; the fifth is longest, and is followed by a slender elongated flagellum. The maxillipeds (pl. I, fig. 5) have the external lamella $(l)$ short and broad, nearly straight on the inner margin, broadly ronnded at the end, and somewhat swollen on the external side; the palpus $(p)$ is five-jointed; the first three segments flattened, first short; second dilated internally and ciliated; third eiliate in the inner margin and narrowed to the base of the fourth segment, which is cylindrical; fifth short, conical. The terminal lobe of the maxilliped bears two rows of eilia near the apex, and on the inner side a row of short styliform organs. The outer maxillæ (pl. I, fig. $6 a$ ) consist of a semioval portion, broad and eiliated at the tip, bearing above the middle two articulated lobes, armed with strong curved setæ at the tip. The inner maxillæ (pl. I, fig. $6 b$ ) are armed with short stout spines, which are strongly spinulose on their inner curved side; inner lobe about half the diameter of the outer. Maudibles with a very much projecting molar process, a comb of pectinated setre, and a dentigerous lamella, or two of them on the left side.

The first three thoracic segments are of about equal length along the median line, and are together nearly equal in length to the last four, which are also subequal along the median line, but the fifth segment appears shorter than the others on account of its short lateral margin, which has both its anterior and posterior angles strongly rounded. The epimeral region of the segments projects at the sides so as to cover the bases of the legs, and is squarish in the first three segments, rounded in the fourth, and still more so in the fifth, and obtusely angulated behind in the sixth aud seventh. The legs are similar in form throughout, but increase in length to the last pair. They have the basis rather robust; the ischimm shorter and flexed on the basis; the merus subtriangular, and tipped with spines; the carpus and propodus eyliudrical, subequal 
in length, but the carpus of larger diameter than the propodus; the dactylus short, cylindrical, and provided with two terminal hooklets. There are a few scattered spinules and setre on the segments, especially the merus, carpus, and propodus. In the males the merus and carpus of the sixth and seventh pairs of legs are provided on their inferior margins with close-set slender curved hairs, which extend nearly the whole length of the carpus and over the distal half of the merus.

The pleon is proportionally broader and shorter in the male (pl. I, fig. S) than in the female (pl. I, fig. 7). It is broadly rounded behind, continuing the outline of the body without break, and is notched at the tip for the insertion of the uropods, which scarcely project beyond the general outline of the body, and consist on each side of a short, stumpy, cylindrical basal segment, a little oblique at the end where it bears two almost rudimentary rami, the inner about twice as large as the onter, and both tipped with a few short setæ. The lateral margin of the pleon, like that of the body generally, is beset with short, scattered, unequal setre or spinules. Underneath, the pleon is excavated for the branchial pleopods, which are covered and protected below in the females (pl. I, fig. 7) by a large subcircular plate, sparsely minutely ciliated on the margin. In the male (pl. I, fig. S) the under surface of the pleon presents on each side a small oval plate, with its inner margin overlapped by a median elongated plate, divided by a central suture, which is open distally. This plate is broad at the base, then narrows toward the middle, after which it expands much more rapidly into an outwardly curved and pointed lobe on each side, ciliated at the tip. Between these two lobes the plate is terminated by two transverse, subquadrate and elongated lobes, which are broadest internally where they are separated along the median line. They are excavated on the anterior margin and less so on the posterior margin, sparsely ciliated behind, and conspicuously so with divergent cilia at the outer short, straight margin. In the females the incubatory ponch appears to be eonfined to the second, third, and fourth segments.

In size as well as coloration this species varies greatly, females being often found with eggs when less than half the size of the specimen figured. They attain a length of $5^{\mathrm{mm}}$ and a breadth of $2^{\mathrm{mm}}$, but the males are at least one-third smaller and somewhat narrower than the females, the sides being more nearly parallel. In color there is also much variation. A common color is a dark, slaty gray, with dots or small blotches of yellowish, this color prevailing along the anterior margin of the head. Very frequently darker or lighter shades of green occur, and the incubatory pouch of the females is often bright green. Some specimens are very light colored or nearly white, often with two or more tranisverse dark bands, with considerable contrast in color; others are reddish brown throughont.

I am unable to separate the Amcrican form, Jcera copiosa Stimpson, from the common English and European species, although they have 
hitherto been regarded as distinct. I have had no males from any European locality, but throngh the kindness of the Rer. A. M. Norman I have had an opportunity of comparing females from Oban, Scotland, with our speeies, and have found no specific differences. The description and figures given by Rev. T. R. R. Stebbing in the Annals and Magazine of Natural History, IV, vol. xrii, p. 79, pl. v, figs. 5 and 6 , show a substantial correspondence in the males also, so that I have regarded the species as common to both coasts. Whether the Greenland species $J$. nivalis Kröyer, and the Sonthern species J. Kröyeri Edwards, are also identical with $J$. albifrons or not, I am mable to determine, in the absence of specimens for comparison. M. Sars says that he has seen specimens of $J$. albifrons Leach from Trieste, but regards the Greenland species as distinct. Möbius regards the species as iden. tical from Greenland to the Mediterranean, and unites them under the name J. marina. Metzger, following Bate and Westwood, is more conservative, using the name $J$. albifrons Leach. Bate and Westwood regard J.nivalis Kröyer and Oniscus marinus O. Fabricius as doubtfully identical with $J$. albifrons, and $J$. Kröyeri Edwards as distinct. $J$. Kröyeri Zaddach $=J$. baltica Friedrich Müller appears to be, without doubt, identical with this species, as it is separated by that anthor from $J$. albifrons Leach only by the position of the eyes, which were incorrectly described by Dr. Leach as close together. I have, therefore, referred these two names to $J$. albifrons as synonyms, as has been done preriously by Lilljeborg and others. J.maculata Parfitt, a species based almost wholly on color markings, I have referred to $J$. allifirons, following Stebbing, who believes that he is "in accord with the anthor of the species" in so doing.

This species is common, and in suitable localities abundant, on the whole coast of New England!, and extends as far north as Labrador! at least, where it was collected by Dr. Packard, who regarded it as identical with J. nivalis Kröyer. It is found among rocks, algæ, and rubbish along the shore, often nearly up to high-water mark, where it may be associated with some of the Oniscide, to which it has a certain resemblance in form. It occurs "probably" all around the coast of England (Bate and Westwood). I have examined specimens from Oban!, Scotland. It extends to Finmark, on the coast of Norway (M. Sars), and is common on all the coasts of the North Sea (Metzger). It is recorded by Möbins in the Baltic among stones and algx down to a depth of $18 \frac{1}{2}$ fathoms. According to M. Sars this species extends to Trieste on the Adriatic, but without specimens I have not attempted to decide in regard to the synonymy of the Mediterranean species. 
Spccimens examincd.

\begin{tabular}{|c|c|c|c|c|c|c|c|c|}
\hline \multirow{2}{*}{ 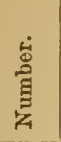 } & \multirow{2}{*}{ Localits. } & \multirow{2}{*}{ 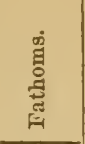 } & \multirow{2}{*}{ Bottom. } & \multirow{2}{*}{$\begin{array}{l}\text { When col- } \\
\text { lected. }\end{array}$} & \multirow{2}{*}{ Received from- } & \multicolumn{2}{|c|}{$\begin{array}{l}\text { Speci. } \\
\text { mons. }\end{array}$} & \multirow{2}{*}{$\begin{array}{l}\text { Dry. } \\
\text { Alc. }\end{array}$} \\
\hline & & & & & & No. & Sex. & \\
\hline 1921 & New Haren, Conn... & & & May 1,1871 & & 20 & & Alc. \\
\hline 1917 & Stony Creek, Conn. . & & & ana............. & & 8 & & Alc. \\
\hline 1916 & Noank IIarbor, Conn. & & &,-- 1874 & U.S. Fish Com . & 25 & & Alc. \\
\hline 1915 & $\begin{array}{l}\text { Vinçard Sound, } \\
\text { Mass. }\end{array}$ & & {$[\cdots \ldots \ldots \ldots \ldots$} &,-- 1871 & .... do .......... & 1 & & Alc. \\
\hline 1914 & ...do .............. & L. W. & Under stones ... &,- 1871 & ....do ........... & $\begin{array}{l}30 \\
50\end{array}$ & & Alc. \\
\hline & $\begin{array}{l}\text { Prorincetown, Mass. } \\
\text {....do }\end{array}$ & & Shore............. & 二, 1872 & ....do. & $\begin{array}{l}50 \\
00\end{array}$ & $\ddot{q}$ & $\begin{array}{l}\text { Alc. } \\
\text { Alc. }\end{array}$ \\
\hline & ...do do & & .... do ............ & Aug. 13,1879 & .... do. & 00 & of & Alc. \\
\hline & 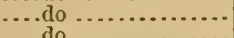 & L. W. & $\ldots \ldots \ldots \ldots$ & Aug. 13, 1879 & .... do ... & 15 & 定 & Alc. \\
\hline & Gloncester, $\mathrm{drass}$ & ........ & $\begin{array}{c}\text { Eel grass } \ldots \ldots \ldots \\
\Delta l g i o \\
\end{array}$ & $\begin{array}{r}\text { Aug. } 23,1879 \\
-, 1878 \\
\end{array}$ & $\mid \begin{array}{l}\ldots \text { do } \\
\ldots . . . \\
\ldots \text { do }\end{array}$ & $\begin{array}{r}6 \\
30\end{array}$ & סீ & Alc. \\
\hline & -... do & & Tide pools ....... & & ....do .......... & 7 & $90^{+}$ & Alc. \\
\hline & Casoo Bay ........... & . & 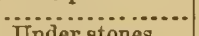 & --1873 & r & & & Alc. \\
\hline $\begin{array}{l}1919 \\
1918\end{array}$ & $\begin{array}{l}\text { Eastport, } \mathrm{Me} . . . \mathrm{.} . \\
\text { Eastport, } \mathrm{Me} ., \mathrm{Dog}\end{array}$ & $\begin{array}{l}\text { L. W. } \\
\text {........ }\end{array}$ & $\begin{array}{l}\text { Under stones ... } \\
\text { Tide pool ....... }\end{array}$ & $\begin{array}{r}1868-1870 \\
-\quad-1872 \\
\end{array}$ & U. E. Fish Com. & $\begin{array}{l}7 \\
5\end{array}$ & & $\begin{array}{l}\text { Alc. } \\
\text { Alc. }\end{array}$ \\
\hline 1912 & $\begin{array}{l}\text { Island. } \\
\text { Indian Tickle, Lab. }\end{array}$ & & & & A. S. Packard . & 7 & & Alo. \\
\hline $519 *$ & $\begin{array}{l}\text { rador. } \\
\text { Hopedale, Labrador. }\end{array}$ & & Stone... & & $\ldots$ do $\ldots . . . . .$. & & & Alc. \\
\hline & Oban, Scotland...... & & ............... &,-- 1877 & $\begin{array}{l}\text { Rev.A.M.Nor- } \\
\text { man. }\end{array}$ & 4 & $\ddot{q}$ & Alc. \\
\hline
\end{tabular}

- Asellus grönlandicue Packard, MSS.

\section{Janira Leach.}

Janira Leach, Edinb. Encyc., vol. vii, p. "434" (Amer. ed., p. 273), "1813-14". Asellodes Stimpson, Mar. Inv. Grand Manan, p. 41, 1853.

Body loosely articulated as in Asellus; antennulæ slender, with a multiarticulate flagellum; antennæe elongated, with a spine, or scale, on the second segment and with a long multiarticulate flagellum; mandibles palpigerous; lateral margins of the thoracic segments not completely covering the bases of the legs; first pair of legs prehensile; the carpus thickened, and the propodus slender and capable of complete flexion on the carpus; dactylus short and armed with two small ungues, as in the succeeding pairs of legs; uropods well developed, biramous.

This genus is represented on our coast by two species, one of which was originally described by Stimpson muder the name Asellodes alta. It does not, however, seem to present any generic differences from Janira maculosa Leach, the type of the present genus. Stimpson's generic description appears to have been drawn from the male, as he says: "External pair of natatory feet having each two lamiuæ, like the others, but broader and hardened, so as to perform the office of an operculum." The two inner of these laminæ are, howerer, united along the median line nearly to the tip, as will be seen below.

Our species of this genus may be further characterized as follows: The body is elongate oral in general outline, between two and three times as long as broad. The eyes are distinct. The head is produced medially into a distinct rostrum, and the antero-lateral angles are also produced, but in the typical species ( $J$. maculosa Leach) the head is rounded ante- 
riorly. The basal segment of the antennulæ is enlarged; the second is more slender and cylindrical; the third is short, eylindrical, or slightly clavate, and is followed by a short subglobose segment having the appearance of a fourth peduncular segment. Beyond this, is a slender multiarticulate flagellum, composed of about twenty to thirty segments, the segmentation becoming indistinct toward the base. These segments are provided, except toward the base, with slender "olfactory setæ." The first three segments of the antennæ are short and robust, and the second bears, near its distal end, on the external side above, a triangular scale, or spine, articulated with the segment and directed forward, ontward, and somewhat upward ; the third segment is eomparatively short and small ; the fourth and fifth segments are slender and elongated, and the flagellum tapers from the base and is composed of many, 80 to 120 or more, segments. The maxillipeds (sce pl. III, fig. $12 a$ ) are broad, with a rhombic-ovate external lamella $(l)$, and a five-jointed palpus $(p)$, of which the first three segments are flattened and expanded internally, where the second and third segments are also ciliated. The last two segments of the palpus are eylindrical, and bent inward toward the median line. The outer maxillæ are rhombic in outline, ciliated and spiny along the inner margin and at the tip, as are also the two slender, curved, articulated lobes. The inner maxillæ consist of the usual curved lobes, armed at the tip with denticulated spines, which are larger, stronger, and more numerous on the onter large lobe. The mandibles are strong, and furnished with an acute dentigerous lamella on the right side, received between two such lamellæ on the left mandible; below is a comb of setæ and a strong molar process. The palpus of the mandible is composed of three subequal segments, the last furnished with a comb of setæ.

The thoracic segments do not greatly exceed the head in transverse diameter, and are subequal, the second, third, and fourth with a lateral emargination. The legs are slender and elongated, ambulatory, or the first pair subprehensile and somewhat shorter than the following pairs. In this pair the carpus is slightly swollen and the propodus is capable of complete flexion upon it. The dactyli are short in all the legs, as compared with the propodi, and capable of only incomplete flexion. They are armed at the tip with two robust unguiform spines.

The pleon is broad and flattened above. The uropods are well developed and consist of a cylindrical or slightly clavate basal segment bearing two rami of which the inner is the larger and longer. The under surface of the pleon is excavated, and in the females is protected beneath by a subcircular operculum, but in the males of $J$. alta, aud probably in both species, the thickened opercular plates are three in number, viz, a pair of semi-oval plates at the sides and a more slender median plate presenting traces of a suture along the middle.

In the females, the incubatory ponch is formed of four pairs of plates attached to the coxal segments of the first four pairs of legs. These plates may usually be easily seen when the females are destitute of eggs, 
being then small, elongate, oval, and lying near the under surface of the thoracic segments.

Janira alta Harger (Stimpson).

Asellodes alta Stimpson, Mar. Inv. G. Manan, p. 41, pl. iii, fig. 30, 1853.

Verrill, Am. Jour. Sci., III, vol. vi, p. 439, 1873; vol. vii, pp. 411, 502, 1874 ; Proc. Amer. Assoc., 1873, p. 350, 1874.

Janira alta Harger, Proc. U. S. Nat. Mus., 1879, vol. ii, p. 158, 1879.

Plates II and III, Figs. 9, 12, ANd 13.

This species may be at once distinguished from the following by the absence of spines in the dorsal and lateral thoracic regions, from all the other known Isopoda of the coast, by the flattened, sentiform and consolidated pleon, bearing well-developed, exerted, biramous uropods, which are, however, fragile. It is more slender than the following species.

The body is elongated oval in outline, nearly three times as long as broad. The head is produced in front into a prominent but short, acute, median spine or rostrum, and the antero-lateral angles are also acutely produced, but are shorter and less acute than the rostrum. The eyes are prominent and black, situated on the upper surface of the head, near the lateral margins. They are elliptical in outline, with the long axes converging toward a point near to, or beyond, the tip of the rostrum. The basal segment of the antennulæ is shorter than the rostrum; the flagellum consists of about thirty segments and does not attain the tip of the fourth antennal segment. The seale on the second segment of the antennæ is short and triangular, does not surpass the following segment, and is tipped with a few slender setæ. The maxillipeds (pl. III, fig. $12 a$ ) hare the external lamella $(l)$ obtusely pointed at the apex and angulated on the outer side, otherwise they resemble the same organs in J. spinosa, as do the onter maxillæ, the inner maxillæ, and the mandibles (pl. III, fig. $12 b)$.

The thoracic segments are but little broader than the head, the first three and the last two segments are about equal to each other in length; the fourth and the fifth are somewhat shorter. The lateral margins of the segments do not cover the epimera from above, and none of them are produced at the sides into acute and salient angulations, as in the next species. In the first segment the lateral margins are rounded and the epimera project as an angular tooth on each side in front. In the second, third, and fourth segments the emargination is behind a prominent but narrow lobe at the anterior angle of the segment and the epimera are two-lobed. In the fourth segment the posterior angle is nearly included in the emargination, and in the last three segments the posterior angle is elided and the epimera occupy its place. The legs are elongated and armed with spines, especially on the carpal segments.

The pleon is rounded-hexagonal in outline, minutely and sharply serrate at the sides behind the middle, and undulated over the bases of 
the uroporls on the posterior margin. The uropods are slender, easily detached, and liable to escape obserration. Thes are nearly alike in the two sexes, and consist on each side of an elongate, somewhat curved and clavate basal segment, bearing at the end two rami, of which the inner is nearly as long as the basal segment, the outer somewhat smaller and shorter. The rumi are slightly flattened, and, like the basal segment, armed with setre, especially at the tip. The branchial pleopods are protreted in the female by a subcireular operculum (pl. III, fig. $13 a$ ). In the male, the inferior surface of the pleon (pl. III, fig. $13 b$ ) presents on each side a nearly semicircular plate $(b)$, with its inner margin overlapped by a median, elongated, and narrow plate $(c)$, marked along the median line by a suture. This plate is broadest near the base, then contracts on each side to beyond the middle, after which it expands slightly. The median suture is open near the tip, and, on each side, is a rounded lobe, separated by a sinus from the produced external angle.

Length of body, exclusive of the antennæ and uropods, $\mathrm{S}^{\mathrm{mm}}$, breadth $3^{\mathrm{mm}}$. Color in alcohol usually pale or brownish, with small black dots on the upper surface. The under surface is lighter, as are the legs and antemne, especially toward their distal extremities.

This species is at once distinguished from the common European $J$. maculosa Leach by the form of the head, which is rostrate, and has also the antero-lateral angles strongly salient, while in $J$. maculosa the anterior margin of the head is nearly straight and the angles are not prodnced. From Henopomus tricornis Kröyer,* as described and figured by that author, it differs in the elongater uropods.

This species has not been found south of Cape Cod. Dr. Stimpson's specimens were "dredged in soft mud in $40 \mathrm{f}$. off Long Island, G. Mr.," in the Bay of Fundy. It was dredged in Massachusetts Bay! in from 54 to 115 fathoms mud, sand, and stones in 1878 . In many localities given below in the Gulf of Maine! from 35 to 115 fathoms in 1873, 1874, and 1877, and 120 miles south of Halifax!, N. S., in 120 fathoms gravel and pebbles in 1877. It has also been obtained from sereral localities in the Bay of Fundy!, in one case at low water on Clark's Lerlge, near Eastport, Me. A specimen was collected in 1879, by Mr. Charles Ruckley, of the scliooner 'H. A. Duncan,' thirty miles east of the Northeast light on Sable Island, adhering to a specimen of Paragorgia, from a depth of 160 to 300 fathoms.

\footnotetext{
"Naturhist. Tidssk., II, B. ii, p. 380, 1847; Voy. en Scand., Crust., pl. xxx, figs. 2 a-q, "1849."
} 
Specimens examined.

\begin{tabular}{|c|c|c|c|c|c|c|c|c|}
\hline \multirow{2}{*}{$\begin{array}{l}\text { 岕 } \\
\text { 总 } \\
\text { 学 }\end{array}$} & \multirow{2}{*}{ Locality. } & \multirow{2}{*}{ 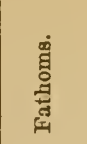 } & \multirow{2}{*}{ Bottom. } & \multirow{2}{*}{$\begin{array}{l}\text { When col- } \\
\text { lected. }\end{array}$} & \multirow{2}{*}{ Receiredfrom- } & \multicolumn{2}{|c|}{$\begin{array}{l}\text { Speci- } \\
\text { mens. }\end{array}$} & \multirow{2}{*}{$\begin{array}{l}\text { Dry. } \\
\text { Alc. }\end{array}$} \\
\hline & & & & & & No. & Sex. & \\
\hline & $\begin{array}{l}\text { Gulf of Mraine, ESE. } \\
\text { from Cape Ann } \\
29-30 \text { miles. }\end{array}$ & 85 & Mud, sand, stoues &,-- 1878 & U.S. Fish Com. & 1 & q & Alc. \\
\hline & $\begin{array}{l}\text { Gulf of Mraine, ESE. } \\
\text { from Cape Ann }\end{array}$ & $110-115$ & Mud, stones .... &,- 1878 & ....do ... & 1 & q. & Alo. \\
\hline & $\begin{array}{l}\text { Gulf of Maine, SE. } \frac{1}{2} \\
\text { S. from Cape A nn }\end{array}$ & $54-60$ & Sand, mud....... &,-- 1878 & .... do .. & 2 & 69 & Alo. \\
\hline 1934 & $\begin{array}{l}\text { Gulf of Maine, SE. } \\
\text { from Cape Ann } 14 \\
\text { miles. }\end{array}$ & 90 & Soft mnd......... &,-- 1877 & ....do . . & 1 & & Alo. \\
\hline 1923 & $\begin{array}{l}\text { mules. } \\
\text { Gulf of Maino, E. } \\
\text { from Cape Ann } 140 \\
\text { miles. }\end{array}$ & $112-115$ & Sond and gravel. &,-- 1877 & ....do .............. & 1 & $\delta$ & Alc. \\
\hline 1935 & $\begin{array}{l}\text { Between Cape Ann } \\
\text { and Isles of Shoals }\end{array}$ & 35 & Clay, sand, mud. &,-- 1874 & ....do .......... & 1 & & Ale. \\
\hline 1924 & $\begin{array}{l}\text { Gulf of Maine, S. of } \\
\text { Cashe's Ledge. }\end{array}$ & 80 & Rocky .... &,-- 1873 & ....do & & & Alc. \\
\hline 1925 & $\begin{array}{l}\text { Casco Bay, Me....... } \\
\text { Banquereau ........ }\end{array}$ & & & $\begin{array}{r}-1873 \\
-1878\end{array}$ & Capt. Collins... & 1 & 오 & $\begin{array}{l}\text { Alc. } \\
\text { Alc. }\end{array}$ \\
\hline 1927 & Bay of Fundy, Mie... & & & --1872 & U.S. Fish Com. & 3 & & Alc. \\
\hline 1928 & $\begin{array}{l}\text { Bay of Fundy, Clark' } \\
\text { Ledge. }\end{array}$ & L. w. -30 & Rocky .... &,-- 1872 & ....do ........... & & & Alc. \\
\hline 1929 & $\begin{array}{l}\text { Bay of Fundy, Buck- } \\
\text { man's Head. }\end{array}$ & & &,-- 1872 & $\ldots$....... & & & Alc. \\
\hline 1930 & Bar of Fundy, off & & & Aug. 27, 1872 & .... do .... & & & Alc. \\
\hline 1932 & Bay of Fundy, East- & & &,-- 1870 & A.E. Verrill... & 1 & & Alc. \\
\hline & $\begin{array}{l}\text { port. } \\
\text { Thirty miles east of } \\
\text { Northeast ligh t } \\
\text { on Sable Island. }\end{array}$ & $160-300$ & On Paragorgia.. &,-- 1879 & Mr.'C.Ruckley. & 1 & $\sigma^{\prime \prime}$ & Dry. \\
\hline 1933 & $\begin{array}{l}\text { South of Halifax } 120 \\
\text { miles. }\end{array}$ & 190 & $\begin{array}{l}\text { Gravel and peb- } \\
\text { bles. }\end{array}$ &,-- 1877 & U.S. Fish Com. & 1 & & Alo. \\
\hline
\end{tabular}

Janira spinosa Harger.

Janira spinosa Harger, Proc. U. S. Nat. Mus., 1879, vol, ii.p. 158, 1879.

This species is well marked among our known Isopoda, by the clouble row of spines along the back and the acute laciniations or angulations on the lateral inargins of the thoracic segments.

The body is robust, the length but little exceeding twice the breadth. The head is broad, and produced in the median line into a prominent acute spine, or rostrum, about as long as the head. The antero-lateral angles are also produced and rery acute, but do not extend as far as the rostrum. The eyes are rounded semi-oval, with the long axes converging toward a point near the base of the rostrum. The basal segment of the antennule is less than one-third the length of the rostrum. The second segment is about as long as the first, but of only about half its diameter. The flagellum equals, or slightly surpasses, the third antennal segment, and consists of about twelve segments. The scale, or spine, on the second segment of the antenna is slender and considerably surpasses the third segment. The external lamella of the maxillipeds has the outer angle prominent, though not acute.

The thoracic segments are producerl laterally into one or two acuto angulations, giving a sharply serrated or dentated outline to the tho 
racic region. The first segment is shorter than the second; the second, third, and fourth are about equal in length; the fifth is about the length of the first; the sixth and serenth each a little longer. The first segment is acutely prodnced at the sides, around the sides of the head, and bears, near the middle of the anterior margin, two short spines, situated abont lialf as far apart as are the eyes, and directed upward and somewhat forward. The second segment has both lateral angles produced into triangular acute processes, of which the anterior is more slender than the posterior and directed more strongly forward. The dorsal spines on this segment are a little farther apart and larger than in the first segment. In the third segment the lateral angulations are more nearly equal than in the second segment and directed less strongly forward. In the specimen figured the third segment bears, on the left side, a single broad angulation, apparently representing the posterior, while the anterior is only indicated by a slight irregularity in the outline. Malformations of this kind appear to be common. The dorsal spines on the third segment are much as in the second. On the fourth segment the anterior angulation is louger than the posterior, and both are directed nearly outward. The dorsal spines on the fourth segment are slightly smaller and nearer together than on the third; but, as in all the preceding segments, they are near the anterior border of the segment. The last three segments are acutely produced at the sides into a single angulation, which is directed more and more backward to the last segment. The dorsal spines on the fifth segment are situated nearer together than on the anterior segments, and rather behind the middle of the segment; they are also smaller than on the preeeding segments. On the last two segments they are near the posterior border of the segment, and become somewhat smaller and nearer together on the last segment. The legs are armed with but few, and rather weak, spines.

The pleon is broadest near the base and tapers posteriorly, where the angles are acutely produced; between these angles the margin is rounded and arched over the bases of the uropods, which are about as long as the pleon and less spiny than in J. alta. The lateral margin of the pleon is armed with very minute acute spinules, and under a higher power the margins of the thoracic segments and of the head are seen to be similarly armed, especially where most exposed.

Length $8^{\mathrm{min}}$, breadth $3.8^{\mathrm{mm}}$; color in alcohol, white.

This species is near Janira laciniata G. O. Sars, ${ }^{*}$ but is distinguished by the donble row of dorsal spines, whereas Sars says of that species, "Superficies dorsalis medio leviter convexa spinis singulis tenuibus ornata."

The only specimens yet known are two females, which were taken adhering to the cable of the schooner 'Marion', by Captain J. W. Collins, at Banquerean, August 25, 1878. 
Munna Kröyer.

Munna Kröyer, Naturhist. Tidssk., B. ii, p. 615, 1839.

Form of the female dilated oval, of the male elongated sublinear; head very broad (about twice as broad as longy), in length equal to one-fourth or one-fifth the length of the animal; eyes occupying the postero-lateral angles of the head, prominent, as if pedunculated but not movable; antennulio inserted above the antennæ and partly covering their bases, short, a little longer than the liead, with a four-jointed peduncle and a ferw-jointed flagellum; antenne elongated, equaling or surpassing the length of the body, with a multiarticulate flagellum; mandibles with a three-jointed palpus; maxillipeds with a five-jointed palpus; legs all armed with two terminal ungues; first pair shorter and more robust than the others, with a prehensile hand formed of the propordus and the dactylus; the remaining pairs ambulatory, increasing gradually in length, so that the last pair equal or surpass the body in length. The segments of the pleon are united into a single vaulted segment, and its inferior surface is covered, in the females, by a single opercular plate, while in the males the operculum is composed of three parts, as in the preceding genera.

The generic description as given above is in part taken from Kröyer, the anthor of the genus. The specimens hitherto obtained do not appear to be separable from his species M. Fabricii, to which I have therefore referred them, although differing somewhat from each other. The material has unfortunately been, most of it, in poor condition, many of the specimens having been dried and much broken.

\section{Munna Fabricii Kröyer.}

MLunna Fabricii Kröyer, Nat. Hist. Tirlssk., II, B. ii, p. 380, 1847 ; Voy. cn Scand., Crust., pl. xxxi, figs. 1 a-q. " $1849 "$.

Reinhardt, Grönlands Krebsdyr., p. 35, 1857.

M. Sars, Christ. Vid. Selsk. Forh., 1858, p. 154, 1859.

Luitken, Greenland Crust., p. 150, 1875.

Harger, Proc. U. S. Nat. Mus., 1879, vol. ii, p. 159, 1879.

Munna, species, Verrill, Am. Jour.Sci., III, vol. vii, p. 133, 1874 ; Proc. An. Assoc., 1873, p. $371,1874$.

i Mrunna Bœckii G. O. Sars, Arch. Math. Nat., B. ii, p. 353 [253], 1877. (Mr. Bœeckii Kröyer?)

\section{Plate III, Fig. 14.}

This species may be at once distinguished from anything else known on our coast by the prominent, as if pedunculated, but immorable, eyes, on the posterior lateral angles of the large head, together with the elongated and slender ambulatory legs in seren pairs, the first pair only being somewhat shorter.

The first specimens obtained in a recognizable condition were small and differed somewhat from later specimens, especially in size and proportions; the differences, however, do not appear to be necessarily other than what might be due to age and size, and are such as are described 
by Kröyer in his specimens of M. Fabricii. The legs in the small specimen figured are considerably shorter than in larger specimens obtained in 1878 , and the flagellum of the antenuula consists in the small specimens of a single segment, or with traces of subdivision into two, while in the large specimens it is four-jointed, with a rudimentary terminal segment.

The borly is in the female elongate oval, tapering posteriorly, and broalest at the third thoracic segment, where the breadth is equal to abont half the length. The males are more slender, and are not dilated behind the head. The hearl forms abont one-fitth of the total length, and is nearly twice as broad as long. Its anterior portion between the bases of the antennulie and antenni is comparatively narrow on its upper surfice, and is romded or obtusely angled in front. Behind the bases of the antemula it is suddenly much dilated at the sides, and a little behind the dilation are the prominent, strongly convex and laterally projecting eyes, immediately behind which the head contracts suddenly in width, and is then slightly rounded behind. The antenulæ arise in a deep sims on the antero-lateral region of the hear. They consist of a four-jointed peduncle followed by a four-jointed flagellum of about the same length as the peduncle. The basal antennular segment is stout, and snbtrigonal in form; the second is more slender and cylindrical, while the third and fourth are subequal, quite short and small, together not orer half as long as the second segment, and should perhaps rather be regarded as flagellar segments. The four flagellar segments are of a little less diameter than the last two peduncular segments, and are long and eylindrical, the fourth being tipped with a rudimentary segment bearing two strong terminal setæ. The antennæ are much larger and stonter than the antemunla and are abont two or three times as long as the body. They are composed of a fire-jointed peduncle and a slender multiartienlate flagellnm. They arise nearly in front of the antennulø and their first three segments are short and stont, not longer taken together than the first two antennular segments. The fourth segment of the antenni is only about half the diameter of the first three segments, but is greatly elongated, nearly or quite equaling in length the head and thorax taken together, and is eylindrical, and provided with a few short setre, especially at the tip. The fifth, or last peduncular, segment is slightly more slender and elongated than the fourth, and is followed by a slencler tapering flagellum composed of abont serenty-fire segments, or, perhaps, in perfect specimens, of a greater number. The maxillipeds are large and broad, as required by the large head, and are furnisherl with a five-jointed palpus, with the basal segment short, the seeond and third flattened and expanded internally, where they are also eiliated; the fourth narrow; the fifth short, and both provided with seattered setre, especially toward the tip.

The first thoracic segment is a little shorter than the second, which is abont equal in length to the third and the fourth; the last three seg- 
ments progressively decrease in length and width, and the seventh is somewhat concealed at the sisles by the swollen base of the pleon. The basal segments of all the legs are much alike in form, and differ but little in size thronghout. They are eylindrical or slightly clavate, the first pair perceptibly shorter and smaller than the second, frem which they increase very slightly to the sixtl, which is the largest, the seventh not being larger than the secont. The legs disarticulate easily at the end of the basal segment, and in the specimens examined nearly all are broken off at this point. Beyond the basal segment the first pair are comparatively short, about half the length of the body. The ischium of the first pair is robust, and a little longer than the meros; the carpus is sulotriangular and armed with strong short spines on its palmar margin; the propodus is albont as long as the ischium, slightly swollen, and armed with a few spines; the dactylns is slurt and armed at the end with two stout enrved clatrs, of which the outer is abont twice the length of the inner; between the claws is a slender bristle. The second and following pairs of legs are much more elongaterl than the first pair, the elongation being principally in the carpus and propodus, and, in a less degree, in the ischium and merus, while the dactylus is comparatively but little elongated. In the secoud pair of legs the propodus is not longer than the carpus, but it becomes proportionally, as well as absolntely, longer in the following pairs until, in the sixth pair, it may be nearly or quite as long as the body and form about two-fifths the whole length of the leg. The daetyli are, in all the legs, comparatively short, often less than one-tenth the length of the propodus, and armed with twomequal claws, of which the longer is about two-thircls as long as the dactylus itself, and the shorter is more than half the length of the longer. In all the legs the ischinm is armed with a few short curred spinules, and the elongated proporlal segments are furnished with scattered, slender and elongated, straight spines, each with a minute bristle near the apex.

The pleon is remarkably swollen near the base, and is somewhat pear-shaped; posteriorly it is deep, aud bears the miarticulate uroports in shallow groores near the end. On the upper surface are a few straight slender spines, and below it is corered in the females by an ovate, obtusely-pointed operenlar plate, and in the males by at trifid operulum, the median portion being slencler, with nearly palallel sides and a centril suture, and the two lateral portions slender, semiovate and pointed behind. The pleon appear's to be carried habitually, during life, flexed upwarl at a considerable angle.

The length of the specimen figured, by Mr. Emmerton (1)l. III, fig. 14), is $1.2^{\mathrm{mm}}$, breadth $0.7^{\mathrm{mm}}$; but specimens obtained in 1878 measure $3.1^{\mathrm{mm}}$ in length, $1.5^{\mathrm{mm}}$ in width, in the female, and $1.1^{\mathrm{mm}}$ in the male. The pleon measures in length $1.1^{\mathrm{mm}}$ and in width $0.8^{\mathrm{mm}}$ in the larger individuals.

A single much mutilated specimen of this species was ilrerlged in 12 fathoms, South Bay, Eastport!, in 1872, by the United States Fish Com- 
mission, and two more specimens, both females, were obtained on eelgrass in Casco Bay! in 1873. Five specimens were obtained adhering to dried specimens of Acanella from 150 fathoms, Western Bank!, in 1878, and a sixth, in 53 fathoms, on Brown's Bank!, in lat. $42050^{\prime} \mathrm{N}$., lon. $65^{\circ} 10^{\prime}$ E., by Captain J. Q. Getchell, of the schooner 'Otis P. Lord,' in the same year. In 1879 a specimen was obtained adhering to Acanthogorgia armata, by Captain George A. Johnson and erew of the schooner 'Augusta H. Johnson,' on Western Bank!, in lat. $43^{\circ} 15^{\prime}$ N., lon. $50^{\circ}$ $20^{\prime}$ E., 200 fathoms. These specimens were, as has been mentioned, consillerably larger than those at first obtained. Kröyer's specimens were from a depth of 50 fathoms, at Godthaab, Sonthern Greenland, and according to M. Sars the species is abundant on the coast of Finmark among Hydroids in the coralline zone. G. O. Sars records $\boldsymbol{M}$. Bockiii Kröyer, which he regards as scarcely differing from this species, at the harbor of Reikjavik, Iceland.

Specimens examined.

\begin{tabular}{|c|c|c|c|c|c|c|c|c|}
\hline \multirow{2}{*}{$\begin{array}{l}\text { 岕 } \\
\text { 葛 } \\
\text { 点 }\end{array}$} & \multirow{2}{*}{ Locality. } & \multirow{2}{*}{ 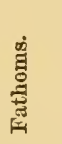 } & \multirow{2}{*}{ Bottom. } & \multirow{2}{*}{$\begin{array}{l}\text { When col- } \\
\text { lected. }\end{array}$} & \multirow{2}{*}{ Received from- } & \multicolumn{2}{|c|}{$\begin{array}{l}\text { Speci- } \\
\text { mens. }\end{array}$} & \multirow{2}{*}{$\begin{array}{l}\text { Dry. } \\
\text { Alo. }\end{array}$} \\
\hline & & & & & & No. & Sex. & \\
\hline \multirow{4}{*}{$\begin{array}{l}2144 \\
1936\end{array}$} & Casco Bay, $\mathrm{Me}_{0} \ldots . .$. & & Eel-grass ........ &,-- 1873 & U.S.Fish Com. & 2 & 9 & Alc. \\
\hline & $\begin{array}{l}\text { Bay of Fundy, Mo .. } \\
\text { Brown's Bank ...... }\end{array}$ & $\begin{array}{l}12 \\
53\end{array}$ & 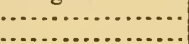 & $\begin{array}{r}-1872 \\
-1878\end{array}$ & Capt. J. Q. & $\frac{1}{1}$ & 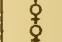 & $\begin{array}{l}\text { Alc. } \\
\text { Dry. }\end{array}$ \\
\hline & Western Bank ...... & 150 & On Acanella.... & --1878 & & 5 & 89 & Dry. \\
\hline & Western Bank....... & 200 & $\begin{array}{l}\text { On A canthogor- } \\
\text { gia armata. }\end{array}$ & - -.1879 & $\begin{array}{l}\text { Capt. G. A. } \\
\text { Johnson. }\end{array}$ & 1 & $q^{+}$ & Dry. \\
\hline
\end{tabular}

\section{IV.-MUNNOPSID A.}

In this family the body consists of two more or less distinct divisions, the first consisting of the head and anterior four thoracic segments, and the second of the last three thoracie segments, and the pleon, which is consolidated into a single segment, convex above. The eyes are wanting. The antenuulæ are much shorter and smaller thau the antennæ, and have their basal segment lamelliform. The antenuæ are much elongated, with a five-jointed peduncle, of which the first three segments are short and the last two elongated and tipped with a long multiarticulate flagellum. The maxillipeds have their basal segments flattened and operculiform, covering the other mouth parts, and furnished with a large external lamella and a five-jointed palpus. The first pair of legs are shorter than the three following pairs and imperfectly prehensile. The next three pairs are ambulatory and usually greatly elongated. The last three pairs of legs, or at least the fifth and sixth pairs, are different in form from the preceding, and fitted for swimting, with some of the distal segments flattened and provided with marginal cilia 
or spines. The pleopods are protected by a thickened opereular plate, and the uropods are short and simple or biramous. The incubatory pouch in the females is beneath the first four thoracic segments.

Of this family, two species have been found on the New England coast, and a third, from the Gulf of St. Lawrence, is here included. The specimens obtained have been mostly in poor condition, and one of these, belonging apparently to an undescribed species, is so imperfect that I have decided to await the collection of better specimens before attempting a specific deseription. In the family characters given above, as well as in the following generic and specific descriptions, I have arailed myself largely of the admirable works of M. Sars and his son G. O. Sars, the distinguished Norwegian naturalists, to whom science is indebted for the discorery and characterization of the present group.

The IInnopside of our coast may be easily recognized as belonging to the family by the structure of the last three pairs of thoracic legs, which are fitted for swimming by being more or less flattened and ciliated; the last pair, however, may return to the more normal type of leg, so that the fifth and sixth pairs only may be natatory. The three genera which appear to be represented are distinguished as follows: Body suddenly constricted and slender behind the fourth thoracic segment in Munnopsis (p. 329); pretty regularly oral in form, with three pairs of flattened natatory legs in Eurycope (p 38); suboval but deeply incised behind the fourth segment, in Ilyarachna (p. 40), in which genus the last pair of legs are scarcely at all flattened or ciliated.

Munnopsis M. Sars.

Munnopsis M. Sars, Christ. Vid. Selsk. Forh., 1860, p. 84, 1861 ; Christ-fjord Fauna, p. 70, 1868.

Anterior division of the body dilated, posterior suddenly much nar. rower and linear. Antennulæ with the basal segment large and flattened, the flagellum elongate and multiarticulate; antennæ very long and slender, many times longer than the body; the last two peduncular segments greatly elongated; the flagellum about equal in length to the peduncle; mandibles subtriangular, entire and acuminate at the apex, without a molar process; the palpus slender with the last segment thick at the base and curved in the form of a hook; penultimate segment of the maxilliped not dilated inwardly; last segment rery narrow and linear. Four anterior thoracic segments excavated above, obtusely rounded at the sides; the three following subcylindrical with short acuminate lateral processes; first four pairs of thoracic legs six-jointed (beyond the coxal segment), the first pair short; the second pair not much longer, rather robust and subprehensile in the males; the two following pairs greatly elongated and very slender, many times longer than the body; but with the basis, ischium, and merus very short; last three pairs of legs natatory, all alike, six-jointed, being destitute of dactyli, with the last two segments, the carpus and propodus, foliaceous, margined with long, slender, delicately plumose setæ. Pleon elongate, much 
longer than broad; abdominal operculum large (nearly covering the whole under surface of the pleon), suboval, simple in the female, but consisting of three distinct segments in the male, one median and very slender, and two lateral, and furnished within with a peculiar curred organ, terminated behind with a much elongated seta; uropods slender uniramous.

Munnopsis typica M. Sars.

Munnopsis typica M. Sars, Chr. Vid. Selsk. Forb., 1860, p. 84, 1861; Christ. Fjorl. Fauna, p. (70), pl. vi-vii, figs. 101-138, 1868; Chr. Vid. Selsk. Forh., 1868, p. 261, 1869 .

G. O. Sars, Chr. Vid. Selsk. Forh., 1863, p. 206, 1864 ; Reise ved Kyst. af Christ., p. (5), 1866; Christ. Fjord Djbvands-fauna, p. (44), 1869 ; Chr. Vid. Selsk. Forh., 1872, p. 79, 1873; Arch. Math. Nat., B. ii, p. 353 [253], $187 \%$.

Whiteaves, Amn. Mag. Nat. Hist., IV, vol. x, p. 347, 1872; Deep-sea Dredging, Gulf of St. Lawrenee (1872), pp. 6, 15, 1873 ; Am. Jour. Sci., III, vol, vii, p. 213, 1874; Further Deep-sea Dredging, Gulf of St. Lawrence (1873), p. 15, 1874.

Buchholz, Zweite Deutsche Nordpolfahrt, Crust., p. 285, 1874.

Heller, Denksch. Acad. Wiss. Wien, B. xxxv, p. (14) 38, 1875.

Norman, Proc. Royal Soe., vol. xxv, 1. 208, 1876.

Miers, Aun. Mag. Nat. Hist., IV, vol. xx, p. 65, 1877.

Harger, Proc. U. S. Nat. Mus., 1879, vol. ii, p. 159, 1879.

Plate II, Fig. 11.

This species is easily recognized among the known Isopoda of our coast by the form of the body, which suddenly diminishes in diameter belind the fourth thoracie segment, so that the last three thoracic segments, bearing the ciliated, swimming legs, are only about half as broad as the anterior part of the body.

Anterior division of the body depressed, posterior subeylindrical; breadth of body less than half the length. Head small, with the length and breadth about equal, equaling the two anterior thoracic segments in length, but of much less breadth, truncate in front and without a rostrum, bearing near the posterior dorsal margin two minute conical tubercles. The eyes are wanting. The antenumle in the female, when reflexed, extend to the third thoracic segment, in the male to the fourth, with the flagellum longer than the peduncle, pectinate or furnished with a longitudinal series of long setæ, multiarticulate; segments in the female, 23 to 28 ; in the male, 65 to 66 . The antenne are greatly elongate, about five times as long as the body, rery slender; peduncle more than twice the length of the borly, the last two peduncular segments beset with numerous short spinules, arranged in longitudinal rows; flagellum nearly as long as the pechncle, composed of about 130 segments. The external lamella $(l)$ of the maxillipeds $(1)$. If, fig. $11 b)$ is narrowed in front with the external margin convex.

The four auterior thoracie segments are subequal, short, abontfive times broader than long; last three segments broader than long, less than 
half the width of the preceding segments, bearing near the anterior dorsal margin two small conical tnbercles; pleon slightly longer than the three precerling segments together, but not narrower, forming somewhat more than one-fourth the length of the body, elongate-suboval, the breadth scarcely equaling half the length, with a median, rounded, dorsal crest, but little elevated, and bearing in front of this near the anterior margin a small conical tubercle.

Propolus shorter than the earpus in the first pair of legs, equal to it in length in the second pair, which in the males (pl. II, fig. $11 \mathrm{c}$ ) havo the carpus thickened, and armed, on tho inferior margin, witli stronger spines than in the females; third and fourth pairs of legs about thrice tho length of the bolly, with the three basal segments, basis, ischium, and merus, very short and robust; the last three very much elongaterl and filiform; the propodus longer than the carpus, both armed with many short spinules arranged longitudinally; dactylus about one-fifth as long as the propodis, slightly curved, naked, very minutely serrulate along the convex margin. Last three legs (pl. II, fig. $11 f$ ) with tho carpus and propodus elongate-subelliptic, both segments strongly eiliated, the propodus a little shorter than the eirpus.

Abdominal operculum in the female (pl. II, fig. 11 g) with a longitudinal, elerated, acute merlian crest, flattened medially in the males. Uropods slightly more than one-third the length of the pleon, composed of two subequal segments. Lamina of the incubatory pouch in the females attached to the anterior four thoracic segments; the three posterior pairs large; the third and fourth suborbicular; the second elongate; the first much smaller, bifid at the apex.

Length $8-10^{\mathrm{mm}}$; antennæ $40-50^{\mathrm{mm}}$; third and fourth pairs of legs 24 $30^{\mathrm{mm}}$. Color, light jellowish, or grayish, in alcohol; lighter below.

The specimens that I have had an opportunity of exanining were all more or less imperfect, and I have therefore, in both the generic and specific descriptions given abore, made free use of the admirable and exhanstice description of this genus and species by M. Sars, * and the figures of the species on plate II were copied from the same author, having been drawu by his not less distinguished son, G. O. Sars.

This species like its allies is an inhabitant of (leep water on mully bottoms. Three specimens, the only ones that I have personally examined, were taken by the Fish Commission in the Bay of Fundy! hetween Head Harbor and the Wolves, in 60 fithoms muddy bottom, Angust 16, 1872. It has been dredged by Mr. Whiteaves in the Gulf of St. Lawrence in 125 to $2: 0$ fathoms; by the Valorous Expedition in Baffin Bar in 100 fathoms (Nomnan); in 25 to 50 fathoms off Cape Napoleon, Grinnell Land, by the Aretic Expedition (Miers); between Norway and Iceland in from 220 to 417 fathoms; Christiania fiord, 200 to 230 fathoms (G. O. Sars); Christiania Sound 50 to 60 fathoms,

* Bidrag til Kundskab om Christiania-fjordens Fauna, 1868, pp. 70-95, pls. vi-vii. (Nyt Magazin.) 
whence the species was described by M. Sars; off Storeggen, 100 fathoms (G. O. Sars), and northward among the Loffoden Islands, 250 fathoms; the coast of Finmark, Spitzbergen (Buchholz), and the Aretic Ocean about Nova Zembla (G. O. Sars.)

\section{Eurycope G. O. Sars.}

Eurycope G. O. Sars, Chr. Vid. Selsk. Forh., 1863, p. 208, 1864.

Body depressed, subovate as seen from above; about equally attenuated before and behind. Head of medium size, more or less produced between the antennulæ; antennæ very slender, two to four times as long as the body; flagellum longer than the perluncle; mandibles robust, quadridentate at the apex, and bearing below a series of rigicl setæe and a strong molar process; mandibular palpus well developed, with the terminal segment enlarged at its base and curved. Four anterior thoracie segments subequal, short; three posterior segments large not suddenly narrower than the anterior segments; the first pair of legs shorter than the next three, with the dactylus short; the next three pairs elongated, and with elongated and slender dactyli; three posterior pairs of legs distinctly natatory, with the carpus and propodus strongly flattened and provided with numerous plumose marginal setæ; dactylus of the ordinary form. Pleon rather large, broader than long, obtusely rounded behind; operenlum subpentagonal with rounded angles, mueh smaller than the pleon. Uropods short, biramous, rami uniarticulate. Dorsal surface of the body smooth and shining.

For the characterization of the genus, as given above, I have depended largely upon the work of G. O. Sars, having had myself, for examination, only the following species:

\section{Eurycope robusta Harger.}

Eurycope robusta Harger, Am. Jour. Sei., III, vol. xv, p. 375, 1878; Proc. U.S. Nat. Mus., 1879, vol. ii, p. 159, 1879.

Plate III, Fig. 15.

This species may be recognized by the flattened and ciliated swimming legs, in three pairs, on the last three thoracic segments, which are not, as in the preceding species, suddenly of much less diameter than the anterior four segments.

Body oval with the length equal to, or slightly exceeding, twice the breadth. Head, behind the bases of the antennulx, longer than the first thoracic segment, produced medially into a short rostrum about half as long as the basal antenmular segment. Antemulre (pl. III, fig. $15 a$ ) attaining the middle of the fourth segment of the antenna in the females, surpassing the middle of this segment in the males; basal segment subquadrate, spinulose at the distal angles, somewhat narrowed from the base, bearing the second much smaller segment a little beyond the middle 
of its superior surface; third segment longer and more slender than the second; flagellum of more than twenty articulations, which become indistinct near the base, and are furnished with terminal setæ. Antennæ about thrice the length of the body in the female, somewhat shorter in the male, the sexes differing in the fourth and fifth segments, which, in the females, are subequal in length and, together, as long as the body, while in the male the fifth is shorter than the fourth, and the two segments together are about two-thirds as long as the body. The flagellum is long, slender, and multiarticulate. Maxillipeds (pl. III, fig. 15 b) with the external lamella sub-rhombic, emarginate on the exterior distal side; palpus five-jointed, first segment short, produced externally into a very acute angle; second and third segments broad and flattened; fourth narrow with the inner angle produced and rounded; fifth short, oval. Maxilla of the ordinary form, outer pair with slender lobes. Mandibular palpus elongated, last segment strongly curved.

Thorax widest at the fourth segment; first four segments forming about one-third its length on the median line, last segment longest, all with their antero-lateral angles produced, the anterior four with the epimera projecting as an acute process below, and in front of, the angle. First pair of legs (pl. III, fig. $15 d$ and $d^{\prime}$ ) about three-fourths the length of the body; dactylus short; propodus shorter than the carpus; slightly hairy, especially on the propodus with slender hairs. Next three pairs of legs longer than the body, subequal, but increasing a little in length to the fourth; dactyli slender and acicular; propodi and carpi subequal, spinulose along their inner margins in the second pair, but not in the third and fourth. Last three pairs of legs with the carpus strongly dilated and flattened, subcircular as seen in pl. III, fig. $15 f$, where the sixth pair is represented ; propodus also much flattened and dilated; both segments strongly ciliated with plumose bristles, as is also the ischium, or second segment along the onter dilated margin; dactylus about half the length of the propodus instead of less than one.third its length, as in E. cornuta G. O. Sars, the species most reseinbling the present.

Pleon much broader than long, broadly rounded behind. Operculum also broader than long, strongly roof-shaped. Uropods (pl. III, fig. $15 \mathrm{~g}$ ) with the basal segment sloorter than the rami, which are uniarticulate, cylindrical, of equal length, obtuse and tipped with a coronet of short spines. The inner ramus is more robust, but not louger than, the outer.

Color in alcohol, honey yellow; length $4.5^{\mathrm{mm}}$; breadth $2.2^{\mathrm{mm}}$.

This species appears to approach $E$. cornuta G. O. Sars,* but may be readily distinguished by its greater size, by the shortness of the rostrum, the equal rami of the uropods, and the shape of the external lamella of the maxillipeds, which he describes in that species as "versus apicem dilatata et emarginata utrinque acute producta." In the third and fourth pairs of legs, moreover, the carpus and propodus are not armed with spines as in that species according to Sars' description.

* Chr. Vid. Selsk. Forh., 1863, p. 209, 1864. 
This speeies was dreiged by Mr. J. F. Whiteares in the Gulf of St. Lawrence! at a depth of 220 fathoms muddy bottom, and has not jet been found on the coast of New England. It is introduced here from the probability that it will yet be discovered in the deeper parts of the Bay of Fundy, where the allied Munnopsis typica M. Sars has already been found, or eren in the Gulf of Maine.

Specimens cxamincd.

\begin{tabular}{|c|c|c|c|c|c|c|c|c|}
\hline \multirow{2}{*}{ 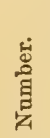 } & \multirow{2}{*}{ Locality. } & \multirow{2}{*}{ 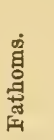 } & \multirow{2}{*}{ Bottom. } & \multirow{2}{*}{$\begin{array}{l}\text { When col- } \\
\text { lected. }\end{array}$} & \multirow{2}{*}{ Receivedfrom- } & \multicolumn{2}{|c|}{$\begin{array}{l}\text { Speci- } \\
\text { mens. }\end{array}$} & \multirow{2}{*}{$\begin{array}{l}\text { Dry. } \\
\text { Alc. }\end{array}$} \\
\hline & & & & & & No. & Sox. & \\
\hline $\begin{array}{l}1938 \\
1939\end{array}$ & $\begin{array}{l}\text { Gulf of St. Lawrence } \\
\text { Gulf of St. Lawrence }\end{array}$ & $\begin{array}{l}220 \\
220\end{array}$ & Mud........ & & $\begin{array}{l}\text { J.F. Whiteaves } \\
\ldots . . \text { do .............. }\end{array}$ & $\begin{array}{r}10 \\
3\end{array}$ & 89 & $\begin{array}{l}\text { Ala. } \\
\text { Ala. }\end{array}$ \\
\hline
\end{tabular}

Ilyarachna G. O. Sars.

Mesostenus G. O. Sars, Chr. Vid. Selsk. Forh., 1863, p. 211, 1864.

Ilyarachna G. O. Sars, Christ. Fjord. Dybvands-fauna, p. (44), 1869.

Body scarcely depressed, subpyriform as seen from above, narrowed behind; its anterior division separated from the posterior by a deep constriction. The head is large and broad and without a rostrum. Antennulie short, with a flagellum composed of but few segments. Antennæe exceediug the body in length, with a multiarticulate flagellum. Mandibles short and strong, entire at the apex; molar process armed with a few setiform spines; palpus either small and three-jointed or wanting. Four anterior thoracic segments short, excavated above and furnished with lateral processes directed forward; the three following convex above and destitute of lateral processes; the antepenultimate scarcely narrower than the anterior segments and deeply emarginate behind. First pair of legs nearly as in the preceding genus; second pair unlike the others and usually more robust; the following two subequal and commonly much elongated; fifth and sixth pairs of legs much as in Eurycope; the last pair unlike the preceding, long and slender, with the segments scarcely flattened, and armed with a long curved claw. Pleon narrowly triangular, pointed at the apex. Abdominal operculum large, covering nearly the whole of the under surface of the pleon, provided with a median crest and numerous marginal setæ. Uropods simple, appressed to the pleon.

For the generic description given above I have depended almost entirely upon the work of Dr. G. O. Sars, who originally described the genus under the name Mesostenus. That name being preoccupied he subsequently changed it to Ilyarachna. 
nyarachna species.

A single imperfect specimen of a species apparently belonging to this genus was dredged in 106 futhoms, gray mud. 21 miles east of Cape Cod Light!, September 18, 1879. The species is probably yet undescribed, but, in riew of the very imperfect condition of the only specimen yet known, I have decided to await the collection of better specimens before attempting to make out its characters. It may yet be found to represent an undescribed genus, but I am at present inclined to regard it as a species of Tlyarachna.

\section{V.-IDOTEIDAE.}

Antennulæ consisting of four segments, of which the basal is inore or less enlarged and, the terminal clavate; mandibles not palpigerous; thoracic segments subequal in length; pleon with more or ferrer of its segments consolidated into a large, scutiform, terminal piece; uropods inferior, transformed into a two-valved operculum protecting the pleopods.

The Idoteidce are represented on the New England coast by ten species; another, found near our northern limits, is included, making eleven in all, belonging to five genera. The family may be further characterized, so far as regards our species, as follows: The body is depressed, and varies in its proportions of length to breadth from about two to one in Chiridotea coea to nearly six to one in Erichsonia attenuata. The head is quadrate in ontline, except in Chiridotea. The eyes are present and usually lateral, but may not be conspicuous. The antennulæ are four-jointed and similar in form throughout the family; they may or may not surpass the head in length, but are usually short and small. The basal segment of the antennule is more or less enlarged and usually subquadrate; the second segment is clavate; the third longer and less distinctly clavate; the fourth, or terminal, segment, corresponding with the flagellum of the antennulæ, is nearly straight along its outer, or in the natural position posterior, margin, while the opposite margin is gently curved from near the base, and romnds orer more sharply at the tip; along this margin, especially toward the tip, are tufts of short setæ at regular intervals, indicating an approach toward segmentation. The antenna have a five-jointed peduncle, varying little in form throughout the famils; the first of these segments is short; the second is much larger and deeply notehed on its under side; the third, fourth, and fifth segments are longer, but more slender and cylindrical or somewhat clavate. The flagellum of the antennæe may be articulated with many or few segments; it may consist of a single segment, or may be rudimentary. The maxillipeds are operculiform and cover the other parts of the mouth below. They consist, on each side, of a large semi-oral plate, with a straight interior margin, meeting its fellow 
of the opposite side, and bearing on this margin a short, cnrved, styliform organ. They are provided at the tip with stout pectinate setx, and along the basal portion of the outer margin lies, on each side, the large external lamella. The palpi of the maxillipeds are flattened and ciliated along their inner margins, and the number of segments may be reduced to three by the coalescence of the last two and of the preceding two. The maxilla vary but little in the fumily; the second or outer pair bear as usual three delicate eiliated plates; the first or inner pair are armed with stouter setre and spines. The mandibles are robust, acutely toothed at the apex, armed with a more or less powerful molar process, and are destitute of palpi.

The thoracic segments are distinct and subequal in length, but may differ considerably in width, and are not united with the head nor with the pleon. The legs, except in the genus Chiridotea, are nearly similar in form throughout, and, in the first three pairs at least, are terminated by a prehensile or subprehensile hand, formed by the more or less complete flexion of the dactylus upon the propodus. The first pair of legs is usually shortest and has a triangular carpus. The anterior three pairs of legs are, in general, directed forward, and the posterior four pairs are directed backward and are less perfectly, or not at all, prehensile, a distinction that reaches its highest development in Chiridotea. The seventh pair of legs are absent in the young taken from the incubatory pouch, and do not generally attain quite as large size as the sixth pair.

The pleon, seen from above, consists in great part, or entirely, of a large, convex, usually pointed, scutiform piece, representing the consolidated terminal segments. As many as four of the anterior segments may, however, be more or less completely separated by articulations or indicated by lateral incisions or sutural lines. Underneath, the pleon is provided with a strneture peculiar to and characteristic of this family, and the next, viz, a two-ralved operculım, formed by the specially modified uropods, * or appendages of the terminal segment, closing like a pair of cupboard doors and protecting the delicate pleopods, which are lodged in a vaulted chamber excavated in the under surface of the pleon. This operculum consists, on each side, of an elon gated basal plate, often strongly vaulter, angulated externally near the base, where it is articulated with the terminal segment of the pleon, and bearing at the tip one, or sometimes two, small lamellæ. One of these lamella usually disappears, but two are present in Chiridotea, as also in the foreign genera Cleantis and Chatilia. When both are present the opercular plates differ only in proportion from the ordinary form of uropods, consisting of a basal segment and two rami. Within the carity enclosed by the opercular plates lie the usual five pairs of pleopods, each consisting of a basal segment

* In the last edition of the Eneycloprdia Britannica (vol. vi, p.641), these organs are described as the "anterior" abdominal appendages. They are anterior only in position, being in fact the appendages of the posterior segment. 
supporting two lamellæ, and two or more of the anterior pairs are ciliated with fine plumose hairs. The inner lamella of the second pair of pleopods bears, in the adult males, a slender style articulated near the base of the inner margin and varying in length and structure in the different genera and species. The pleopods, besides their branchial office, are also of importance in locomotion, being used for swimming, which is a frequent mode of progression in this family, and is often performed with the back downward.

The females are usually broader than the males and carry their eggs and young in a pouch, on the under surface of the thorax, formed of four pairs of plates, attached to the coxal segments of the second, third, fourth, and fifth pairs of legs, and overlapping along the median line.

The known Isoporta of this family on the coast may be most easily recognized by the presence, underneath the pleon, of a two-valved opereulum, opening like a pair of eupboard cloors, and by the first three pairs of legs being more or less prehensile. Our genera may be distinguished by means of the following table:

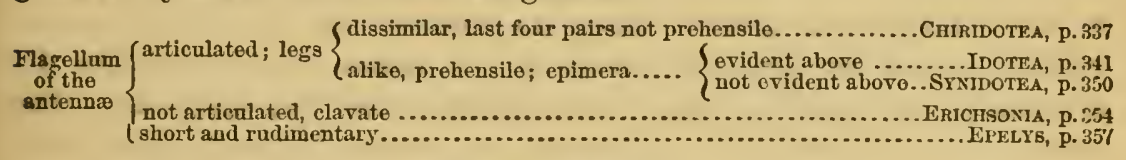

\section{Chiridotea Harger.}

Chiridotea Harger, Am. Jour. Sci., III, vol. xv, p. 374, 1878.

First three pairs of legs terminated by prehensile hands, in each of which the carpus is short and triangular, the propodus is robust and the dactylus is capable of complete flexion on the propodus; antennæe with an articulated flagellum; head dilated laterally; abdominal operculum vaulted, with two apical plates.

The two species of this genus found on our coast agree further in the following particulars: The body is short, the length being only about twice the breadth, and the outline of the head and thorax together is subcircular. The anterior part of the lateral margin of the head is produced and deeply lobed, the eyes thus appearing dorsal instead of lateral; posteriorly the head is deeply received into the first thoracic segment. The antennulie are proportionally large, equaling or surpassing the peduncle of the antennx. The external lamella of the maxillipeds (see pl. IV, figs. 18 and 21) is large and broad and the palpus consists of only three segments, of which, howerer, the last two are each composed of two coalesced segments, that are separate in the European Ch. entomon. Of the two segments thus formed, the terminal is quadrate or rhomboid in outline, with rounded angles and is smaller than the preceding, which expands distally toward the articulation between the two.

The thorax is deeply excarated, in frout for the head and behind for the abdomen, so that the thoracic segments are much longer at the sides than along the back, when measured parallel with the axis of the animal. The 
epimera are separated by sutures, except in the first segment, and have their posterior angles acute. The first three pairs of legs have the dactylus capable of complete flexion upon the propodus, which is more or less swollen and supported by the short triangular earpus. In the last four pairs of legs the three corresponding segments are nearly cylindrical and the dactylus is incapable of complete flexion on the propodus.

The pleon, or abdomen, is convex throughout and pointed at the tip, and is composed, apparently, of five segments, of which the first three are separated by complete sutures, but the last two are united in the dorsal region, the sutures separating them being risible only at the sides. The opercular plates consist, on each side, of an elongated, vaulted, and attenuated plate, regularly rounded at the anterior end, truncate at the apex, and bearing just within the apex, on the inner side of the organ when elosed, two ciliated, ovate or triangular plates. Of these the internal plate, or the one next the median line is much smaller than the outer; the outer also overlaps the inner, a disposition similar to that which prevails in the branchial plates or pleopods. The basal plate of the opereulum is eiliated along its anterior and inner margin with bristles, which are plumose except in the region nearly opposite the articulation of the plate, where they become stonter and spine-like. The stylet on the second pair of pleopods in the males is long and slender, more than twice the length of the lamella to which it is attached.

Chiridotea cœca Harger (Say).

Idotea coeca Say, Jour. Acad. Nat. Sci. Phil., vol. i, p. 424, 1818.

Hitchcock, Rep. Geol. Mass., p. 564, 1833. (I. cœca $\$$ )

Gould, Rep. Geol. Mass., 2 d cd., p. 549, 1835 ; Invert. Mass., p. 337, 1841.

Edwards, Hist. nat. des Crust., tom. iii, p. 131, 1840.

Guérin, Iconog., Crust., p. 35, 1843.

Dekay, Zool. Now York, Crust., 1. 42, 1844.

White, List Crust. Brit. Mus., p. 94, 1847.

Verrill, This Report, part i, p. 340 (46), 18 r4.

Harger, This Report, part i, p. 569 (275); pl. v, fig. 22, 1874.

Chiridotea cœea Harger, Am. Jour. Sci., III, vol. xv, p. 374, 1878; Proc. U.S. Nat. Mus., 1879, vol. ii, p. 159, 1879.

Plate IV, Figs. 16-19.

This species is at once distinguished from the following by its larger size and short antennæ, which surpass the antennulæ but little, if at all. Among the other known Isopoda of the New England coast, it may be recognized by the broad, subcircular thorax, joined with an articulated flagellum of the antennæ and a two-valved abdominal opereulum. The eyes are, moreover, light-colored and inconspicuous, whence the name.

The head is but slightly excavated in front for the bases of the antennæ, and there is a more or less open notch at the sides extending nearly to the eyes. The antennulæ (pl. IV, fig. $17 a$ ) are longer than the peduncle of the antennre and have the second segment strongly elavate; the third eylindrical; the last with about a dozen tufts of short 
setr; the peduneular segments are bristly, as are also those of the antennæ. The first segment of the antenuæ (pl. IV, fig. $17 \mathrm{~b}$ ) is very short, the second abont three times as long, longer than any of the fullowing segments; the third is longer and more slender than the fourth, which is nearly as broad as long; the fifth, or last peduncular, segment is more slender than any of the precerling, slightly clavate, about twice as long as broatl, and longer than any except the second. The flagellum slightly exceeds the list two peduncular segments in length and consists usually of about seren segments, each bearing a tuft of short hairs near its extremity, except the first, which is much the longest, bears two such tufts, and is, apparently, composed of two segments united.

The breadth of the thorax is greater than its length along the median line. The first pair of legs (pl. IV, fig. $18 b$ ) are a little shorter than the next two pairs, and the propodus or penultimate segment is a little more swollen. The carpus becomes slightly more elongated in the next two pairs. The last four pairs of legs are alike in form and increase in size to the sixth pair, which is the largest. The legs are bristly hairy, especially on the ischial, meral, and carpal segments, where they are provided with stout setæe curved at the tip. The basal segments bear longer and more slender plumose hairs. The epimera are eiliated on their external margins as are the lateral borders of the head and first thoracic segment and the tip of the pleon.

The opereulum (pl. IV, fig. $18 \mathrm{c}$ ) is also ciliated with very fine hairs along its postero-external margin; the larger of the apical plates is broader than in the following species, the width being to the length as 6 to 10 . The stylet on the second pair of pleopods in the male (pl. IV, fig. $19 b$ ) considerably surpasses the cilia and is curved and acute at the tip. Adult males and females seem to be comparatively rare, and a common form of the second pair of pleopods (pl. IV, fig. 19 a) presents an acute stylet, imperfectly separated from the lamella and but slightly surpassing it in length, strongly ciliated like the lamella on its margin.

Length $12-15^{\mathrm{mm}}$; brearth $6-8^{\mathrm{mm}}$. The color in life is variable but usually dark grayish, much like the wet sand in or on which it is commonly found. It may be more particularly described as usually of a dark leaden gray ou the top of the thorax, sometimes with a central spot, which may be bright pea-green, probably from the contents of the digestive cavity showing through. This dark color is continued in an arrow-shaped, or halberd-shaped, spot occupying most of the upper surface of the head. At the sides of the head and body is a mottling of light yellowish gray, darker again on the edge. The under surface of the body and the legs are pale and generally uniform in color: In alcohol the colors usually fach to a uniform straw color, with fine blackish dots, which are less conspiconous in life.

According to Say this species extends as far sonth as Florida. It is common on sandy beaches at many localities on the coast of New England, as at New Haven! and other localities on Long Island Sound!, 
Vineyard Sound!, Nantucket!, Provincetown!, and Nahant, Mass.! It appears to be very rare, or perhaps does not occur in the northern part of the Gulf of Maine, where it is replaced by the next species; it reappears, however, on the coast of Nova Scotia, having been collected at low water by the U. S. Fish Commission in 1877, at Halifax!. It is usually found on sand below high tide, or burrowing just under the surface, but also swims with facility.

Specimens examined.

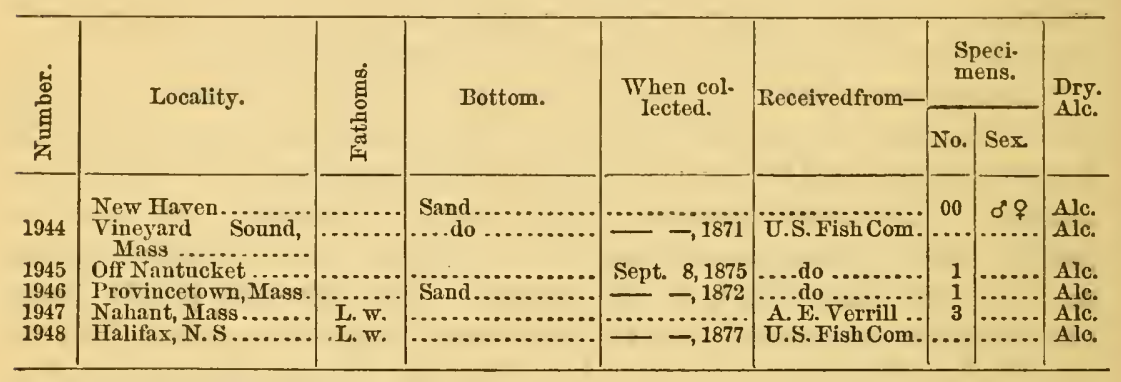

Chiridotea Tuftsii Harger (Stimpson).

Idotea Tuftsii Stimpson, Mar. Inv. G. Manan, p. 39, 1853.

Verrill, Proc. Am. Assoc., 1873, p. 362, 1874; This Report, part i, p. 340 (46), 1874.

Harger, This Report, part i, p. 569 (275), 1874.

Chiridotea Tuftsii Harger, Am. Jour. Sci., III, vol. xv, p. 374, 1878; Proc. U.S. Nat. Mus., 1879, vol. ii, p. 159, 1879.

\section{Plates IV and V, Figs. 20-23.}

This species is distinguished from the preceding by its smaller size and longer antennæ, which are about twice as long as the antennulæ and bear a slender flagellum. The eyes are also more conspicnous than in $C h$. cœeca.

The head is excavated in front above the bases of the antenna; and the incision in the produced lateral margin is nearly closed by the orerlapping of the anterior lobe. The antennulx (pl. V, fig. $23 \mathrm{a}$ ) are slender and do not surpass the peduncle of the antenna, the secoud segment as well as the third is cylindrical, and the last segment bears about nine tufts of short hairs; the perinncular segments bear also a few bristles. The antennæ (pl. V, fig. $23 b$ ) have the first segment short; the second, third and fourth about equal in length and more than twice as long as the first; the fifth as long as the third and fourth together, but more slender and cylindrical; the flagellum longer than the peduncle, composed of about twelve segments and tapering from the base. The maxillipeds (pl. IV, fig. 21) have the external lamella (c) longer than broad.

The first pair of legs (pl. V, fig. $23 \mathrm{c}$ ) are somewhat less robust than in Ch. coca. They are a little shorter than the second and third pairs, and 
have a much more robust hand. The fourth and succeding pairs of legs (pl. V, fig. 23 ( $)$ are much as in the preceding species but less spiny and with a greater proportion of plumose hairs.

The external apical plate of the operculum (pl. V, fig. $23 e$ ) is slender and twice as long as broarl. The stylet on the second pair of pleopods in the males (pl. IV, tig. $22 \mathrm{~s}$ ) does not surpass the cilia, is dilated towards the tip and obtnsely pointed.

Length $9^{\mathrm{mm}}$; breadth $4.5^{\mathrm{mm}}$. The color is usually light reddish brown, speckled with darker, or markel with dark transverse patehes, or bands. A specimen obtained during the summer of 1879 , from a clear saudy bottom in 17 fathoms, Stellwagen's Bank, is thus described from life by Professor Verrill: "Color whitish, more or less speckled with salmon on the sides above, the specks more regular and distinct on the head, some lines and specks of flake-white on the middle of the back above the greenish stomach; base of telson salmon brown, its posterior half white; legs marked with salmon."

Dr. Stimpson's specimen "was drerged on a sandy bottom in 10 fathoms off Cheney's Head" in the Bay of Fundy. It occurs in Long Island Sound, where a specimen was taken by Dr. T. M. Prudden off New London! in 1872. The species was, however, considered rare on the coast until 1S78, when it was taken in considerable abundance in Gloucester Harbor,! Massachusetts Bay, in seren to eight and a half fathoms, sand and red algæ. It has also been colleeted at Casco Bay,! Maine, in 1S73; at low water in Prince's Cove,! Eastport, in the Bay of Fundy, in 1S72, and at Halifax, N. S.,! in 18 to 25 fathoms, sand, September 5, 1877; a single specimen in each case. Three additional specimens wero obtained in 1879, as detailed below.

Specimens cxamined.

\begin{tabular}{|c|c|c|c|c|c|c|c|c|}
\hline \multirow{2}{*}{ 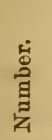 } & \multirow{2}{*}{ Locality. } & \multirow{2}{*}{ 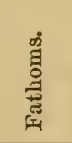 } & \multirow{2}{*}{ Bottom. } & \multirow{2}{*}{$\begin{array}{l}\text { When col- } \\
\text { lected. }\end{array}$} & \multirow{2}{*}{ Receivedfrom- } & \multicolumn{2}{|c|}{$\begin{array}{l}\text { Speci- } \\
\text { mens. }\end{array}$} & \multirow{2}{*}{$\begin{array}{l}\text { Dry. } \\
\text { Ale. }\end{array}$} \\
\hline & & & & & & No. & Sex. & \\
\hline 1953 & $\begin{array}{l}\text { Off New Lonilon..... } \\
\text { Glnucester Harbor, } \\
\text { Mrassachusetts Bay }\end{array}$ & $8 \frac{1}{2}$ & Sand..... & - - 1872 & $\begin{array}{l}\text { T. Mr. Prudden } \\
\text { U.S. Fish Ciom. }\end{array}$ & $\begin{array}{r}1 \\
10\end{array}$ & $\sigma^{\circ}$ & $\begin{array}{l}\text { Alc. } \\
\text { Alc. }\end{array}$ \\
\hline & $\begin{array}{l}\text { Stell .................. } \\
\text { Off Joston's Bank. } \\
\text { Ofarbor.. }\end{array}$ & $\begin{array}{l}7 \frac{1}{2} \\
17^{2} \\
16\end{array}$ & $\begin{array}{l}\text { Coarso samit...... } \\
\text { Speckled sand .. }\end{array}$ & $\begin{array}{l}-1878 \\
\text { Sept. } 6,1879 \\
\text { Sept. 13, 1879 }\end{array}$ & \begin{tabular}{c}
$\ldots$ do $\ldots$ \\
$\ldots$ dlo $\ldots$ \\
\hdashline$\ldots$ do \\
...
\end{tabular} & $\begin{array}{r}00 \\
1 \\
2\end{array}$ & of? & $\begin{array}{l}\text { Alc. } \\
\text { Alc. } \\
\text { Alc. }\end{array}$ \\
\hline $\begin{array}{r}803 \\
1952\end{array}$ & $\begin{array}{l}\text { Casco Bay, Mre ....... } \\
\text { Bay Fundy, Prince's }\end{array}$ & L. $\mathrm{w}$. & Sand $\ldots \ldots \ldots . . . . . . .$. & July 12,1873 & 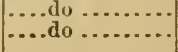 & $\begin{array}{l}1 \\
1\end{array}$ & & $\begin{array}{l}\text { Alc. } \\
\text { Alc. }\end{array}$ \\
\hline 1951 & $\begin{array}{l}\text { Halifax, outer har. } \\
\text { bor. }\end{array}$ & $18-25$ & .....do & Sept. 5,1877 & ....do ... & 1 & & Alc. \\
\hline
\end{tabular}

Idotea Fabricius.

Idotea Fabricius, Suppl. Ent. Syst., p. 297, 1798.

Flagellum of the antennæ articulated; legs all terminated by a prehensile hand; epimeral sutures evident above except in the first thoracic 


\section{REPORT OF COMMISSIONER OF FISH AND FISHERIES.}

segment; pleon composed apparently of four segments, of which the last two are consolidated in the dorsal region; operenlum with a single apical plate.

The species to which I propose to limit the name Itotea* may be briefly characterized as above, and, of these, the three found ou our coast agree further as follows: The body is elongated, its length being from three to four times its breadth, and the sides are nearly parallel. The head is quadrate and not prodneed at the siles. The eyes are lateral. The antenumla are small and short, hardly surpassing the third segment of the antennx. The basal segment of the antennx is very short; the second segment much larger and deeply incised on its muder surface; the third, fourth and fifth segments increase in length but decrease in diameter; the flagellum is more or less distinctly articulated, the number of articulations increasing with age. The palpus of the maxillipeds is four-jointed, the last segment being composed of two segments united, as is indicated by a notch near the tip.

The thorax is moderately arched, with the sides but little dilated in the males, somewhat more so in the females. The epimera are conspicuons and separated from their segments by a suture abore, except in the first segment, but may not oeenpy its entire lateral margin. The legs differ but little in form throughout, being all more or less perfectly prelsensile, but in the first pair only is the carpus triangular.

The pleon or abrlomen appears, when seen from above, to consist of four segments, of which the first two are separated by complete sutures, but the third and fourth by sutures at the sides only. The uropods, forming the abdominal operenlum, eonsist on each side of a flattened, elongated plate, with the anterior end rounder, the sides nearly parallel for most, or all, of its length and bearing at its truneated apex a much shorter more or less tapering or triangular plate. Neither of these plates is strongly ciliated in our species, but a stout, densely plumose bristle springs from the basal plate, on the inside, near the outer end of the articulation between the tro plates. Thestylet ou the second pair of pleopods of the males is not elongated and may not surpass the lamella to which it is attached. The incubatory pouch is conspicuous in the females.

Onr representatives of this genus may be reeognized among the other known Isopoda of the coast by the following characters: The pleon appears to consist of four segments, the first three short and the third united, in the dorsal region, to the large, more or less vaulted, terminal segment; underneath the pleon is the conspicnous two-valved operculum and, in the antennie, the flagellum eonsists of several segments. The three species may be distinguished by the form of the tip of the pleon, which is more or less tridentate in $I$. irrorata (p. 343 ), pointed in $I$. phosphorea (p. 347), and truneate in I. robusta (1).349).

* The orthography adopted is that of Fabricius, the author of the genus. 


\section{Idotea Irrorata Edwards (Say).}

Idotea entomon Leach, Erinb. Eneyc, vol. vii, ( $\Lambda \mathrm{m}$. edl., p. 243, pl. cexxi, fig. 7), "1813-14"; Traus. Liun. Soc., vol. xi, p. 364, 1815 (not Oniscus entomon. Linne.)

Templeton, Loud. Mag. Nat. Hist., vol. ix, p. 9:3, 1836.

Moore, Charlesworth's Mag. Nat. Ilist., vol. iii, p. 294, 1839.

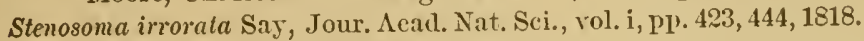

Ifitcheock, Rep. Geol. Mass., p. 564, $18: 33$.

Gonld, Rep. Geol. Mass., 2 ecl., p. 549, 1835 ; Invert. Mass., p. 338, 1841.

Dekay, Zool. New York, Crust., p. 43, pl. ix, fig. 42, 1844.

Idotea trieuspidata Desmarest, Diet. des Sci. nat., tom. xxviii, p. 373, pl. 46, fig. 11, 18:3 ; Consid. Crust., p. 259, p1. 46, fig. 11, 1825.

"Roux, Crust. Medit. , t. 29, f. 11, 12," (B. \& WV.)

Latreille, Regne Anim., t. iv, p. 139, 1829.

Gould, Rep. Geol. Mass., 2 ed., p. 549, 1835 (trieuspidata ).

Edwarls, Hist. nat. des Crust., tom. iii, p. 129, 1840.

Gersted, Naturliist. Tidssk., B. iii, p. 561, 1841.

Zaddach, Crust. Pruss. Prod., p. 10, " 1814."

Lucas, Expl. Algérie, tom. i, p. 60, 1849.

White, List Crust. Brit. Mus., p.94, 1847 ; Brit. Crust. Brit. Mus., p. 65, 1850 ; Pop. Hist. Brit. Crust., p. 223, pl. 12, fig. 2, 1857.

Hope, Cat. Crost. Ital., p. 26, 1851.

Lilljeborg, Öfvers. Vet.-Acad. Förh., Arg. 9, p. 11, 1852 (Idothea).

M. Sars, Chr. Vid. Selsk. Forh., 1858, p. 151, 1859 (Idothea.)

Bate, Rep. Brit. Assoc., 1860, p. 225, 1861.

Norman, Nat. Hist. Trans. Northumb., vol. i, p. 25, 1865; Rep. Brit. Assoo., 1866, p. 197, 1867; op. eit., 1868, p. 289, 1869.

G. O. Sars, Reise ved Kyst. af Christ., 1865, p. (28), 1866 (Idothea).

Heller, Verh. zool.-bot. Ges. Wien, B. xvi, p. 728, 1866 (Idothea).

Marcusen, Arch. Naturges., Jahrgang xxxiii, B. 1, p. 360, 1867.

Bate and Westwood, Brit. Sess. Crust., vol. ii, p. 379, figure, 1868.

"Sænger, Fauna of Baltic, Imp. Soc. Nat. Sc. Mose., viii, 1869."

"Mïnter und Buchlolz, Carcin. Fauna Deutschlands, 1869."

Czerniarski, Zoog. Pont. Comp., pp. 83, 129, "1870."

Metzger, J. B. Naturhist. Ges. Hannover, vol. xx, p. 32, 1871; Nordseefahrt der Pomm., 1872-73, 1. 285, 1875.

Möbius, Die Wirbellosen Thiere der Ostsee, p. 121, 1873. Ann. Mag. Nat. Hist., IV, vol. xii, p. 85, 1873.

Parfitt, Trans. Devon. Assoe., Sess. Crust., p. (19), 1873.

Bos, Bijcl. ken. Crust. Hed. Nederl., pp. 34, 67, 1874.

M'Intosh, Ann. Mag. Nat. Hist., IV, vol. xiv, p. 273, 1874.

Stebbing, Jour. Linn. Soc., vol. xii, p. 148, 1874.

Catta, Ann. Sci. nat., Zool., VI, tome iii, p. 30, $18 \% 6$.

Stalio, Cat. Crost. Adriatic, p. 206, $187 \%$.

Lenz, Wirhellos. Thiere, Trave. Buelit, p. 15, 1878.

Idotea Basteri Audouin, Deser. Savigny's Egrpt, Crust., pl. 12, fig. 6, "1830."

Guerin. Iconog., Crust., p. 32, pl. xxxi, fig. 1, 1829-43.

"Roux, Crust. Mediterr., t. 29, f. 1-10," 1830 (B. \& W.).

"Rathke, Fauna der Krimm, p. 380," 1830 (Edw.).

"Idotea variegata Roux, Crust. Mediterr., 11. 30, fig. 1-9," 1830 (B. \& W.).

Idotea (pelagica?) Latreille, Cours d'Ent., Atlas, p. 12, pl. xviii, figs. 20-30, 1831.

"Armida bimarginata Risso, Hist. nat. Eur. merid., 5, 109" (B. \& W.).

Idotea irrorata Edwards, Hist. nat. des Crust., tomo iii, p. 132, 1840.

White, List Crust. Brit. Mus., p. 94, 1847.

Stimpson, Mar. Inv. G. Manan, p. 39, 1853.

Leidy, Jour. Acad. Nat. Sci. Phil., II, vol. iii., p. 150, 1855. 
Idotea irrorata-Continuel.

Harger, This Report, part i, p. 569 (275), pl. v, fig. 23, 1874 ; Proc. U. S. Nat. Mus., 1879, vol. ii, p. 160, 1879.

Verrill, Am. Jour. Sci., III, vol. vii, pp. 131, 135, 1874 ; Proc. Amer. Assoc., 1873, p1. 369, 371, 373, 1874; This Report, part i, p. 316 (22), 1874.

Whiteaves, Am. Jour. Sci., III, vol. vii, p. 21\%, 1874; Further Deep-sea Drerging, Gulf of St. Lawrence, 1. 15, "1874."

Idothea tridentata Rathke, Fanna Norw., Nov. Act. Acad., B. xx, p. 21, 1843 ( . tridentata Latreille?).

Grube, Ausflug nach Triest, p. 126, 1861.

? Idotea tricuspis Dekay, Zool. New York, Crust., p. 42, pl.9, fig. 35, 1844.

Oniscus Balthicus (Idcotea marina) Dalyell, Powers of the Creator, vol. i, p. 228, pl. lxiii, figs. 5-9, 1851 (O. Balthicns Pallas?).

Oniscus (Ideotea) entomon Dalyell, op. cit. vol. i, p. 229, pl. 1xiii, fig. 10, 1851 (not O. entomon Linné.).

Idothea pelayica, M. Sars, Chr. Vid. Selsk. Forh., 1858, p. 151, 1859 (not of Leach).

" Ydotea acuminata Eichwald, Fauna Caspio-Caucasia, p. \$32-233, tab. xxxvii, fig. 6, 1842" (Czerniarski).

Idothea balthica Meinert, Crust. Isop. Amph. Dec. Daniæ, pp. 21, 228, etc., "1877" (Oniscus Balthicus Pallas?).

Plate V, Figs. 24-26.

Adults of this species are at once distinguished from the other species of the genus ou our coast by the tridentate abdomen, or pleon, and young indiridnals, which often resemble $I$. phosphorea, may be distinguished by the epimeral sutures, which extend quite across the second and suceeeding thoracic segments. For eharacter separating them from the other Isopoda of the coast, see at the elose of the generic description.

The body is smooth, not tubercular nor roughened. The head is nearly square, narrowing but slightly behind. The eyes are small. The antennulæ (pl. V, fig. 25 a) are short, hardly surpassing the third segment of the antennie. The flagellum of the antenma (pl. V, fig. $25 \mathrm{~b}$ ) is longer than the perluncle, distinctly articulated, slender, and composed of from twelve to sixteen seginents in the adults. When reflexed it reaches the third thoracie segment. The external lamella $(l)$ of the maxillipeds (pl. V, fig. $26 \mathrm{a}$ ) is about twice as long as broad, and is obliquely trumeated.

Thorax with the external margins, as seen from above, forming in the adults, a pretty regular curved line, the segments being marked by incisions instead of by serratures as in the other species. In the second and third, as well as in the posterior seg'ments, this margin is formed wholly by the epimera.

The first three segments of the pleon terminate in acute teeth at the sides. The fourth, or last segment, has its lateral margins straight, and is more or less tridentate at the tip, the middle tooth being much the largest. In the operculum (pl. V, fig. $25 \mathrm{c}$ ) the basal plate is abont three times as long as the terminal one, which is broadly truncate at the apex. The stylet $(s)$ on the second pair of pleopods in the males (pl. $\nabla$, fig. $26 \mathrm{~b}$ ) is usually shorter than, or, in smaller specimens, about as long as the lamella to which it is attached, and is abruptly bent toward the 
lamella at the apex and very obliqnely truicated. It is minutely serrulate toward the tip on the side opposite the liwella.

The males of this species sometimes attain a length of $30^{\mathrm{mm}}$ to $35^{\mathrm{mm}}$, with a breadth of $\mathrm{S}^{\mathrm{mm}}$ to $9^{\mathrm{mm}}$ but the females are smaller, rarely, if ever, exceeding $20^{\mathrm{mm}}$ in lengtlı, with a brealth of $\left(. .5^{\mathrm{mm}}\right.$, and are found witis eggs when not over $7.5^{\mathrm{mm}}$ in length. The color varies greatly. Frequently it is of a nearly miform light or dark green, or brownish with minute blackish punctations. It is often iongitudinally striped with light color, or nearly white on a dark backgromud, and the stripes may be mirginal only, or accompanied, especially in the males, by a median dorsal stripe. More rarely the eolors are arranged transversely in bands or blotehes, and specimens thus marked are easily mistaken for the mext species. The females are usually darker than the males, and often with a light lateral stripe, which may be very narrow or broken into a series of blotehes.

A comparison of specimens from both sirles of the Atlantie does not seem to furnish any characters by which to separate this speeies from the common Enropean form, I. tricuspidata Desm., and as Say's trivial name has priority I have adopted it. I. tridentata Rathke appears to be the same species, but $I$. tridentata Latreille* is deseribed by that author as having antennæ as long as the body; fur. ther, Desmarest, just before his original description of $I$. tricuspidata says: "M. Latreille fait observer que cette idotée [I. entomon] est bien différente de celle que Мr. Leach a décrite sous le même nom, * * * * cette dernière qu'il nomme Idotée tricuspide," \&c. It would not therefore appear that Latreille was at that time aware that this species had a name, much less that he had himself named it $I$. tridentata. Again, in his Cours d' Entomologie, where he copies figures, doubtless of this species, from Savigny's Egypt, he applies to them the name Idotea (pelagica?), not recognizing them as his own species. Bate and Westrood quote $I$. tridentata Latreille as a synonym of $I$. tricuspidata Desm., and their quotation $\dagger$ appears intended to refer to a work nearly twenty years older than that of Desmarest. They do not, however, give their reasons for deriating from the ordinary rules of priority, but, perhaps, con. sidered as sufficient the authority of Edwards, who does the same thing. Edwards' deseription of $I$. tricuspidata Desm. contains, moreover, an evident error, the speeies being plaeed in a section of the genus which he thus deseribes: "§ 2 Espèces dont l'abdomen se compose de trois articles parfaitement distincts (le second étant composé de deux annenx soudés ensemble sur le milieu du dos, mais séparés par une scissure sur les côtés)." I. irrorata is included in the same section, but under a subsection, thus correetly characterized: "aa Le second artiele de l'abdomen simple; le troisième offrant près de sa base une fissure de chaque

* Gen. Crust. et Ins., tome i, p. 64, 1806.

† Brit. Sess. Crust., vol. ii, p. 380. The quotation reads, "Idotea tridentata Latreille, Con. Crust. et Ins. 1, p. 64," and was doubtless intended for Gen. Crust. et Ins., [tome] i, p. 64, [1806]. 
côté." No species of Idotea that I have seen has the second segment of the pleon composed of two segments, united along the back but separated by an incision at the sides, as described in the parenthesis above, and two certainly of the other species included by Edwards in the section with $I$. tricuspidata agree with it in the strueture of the pleon as described in 1 . irrorata. Meinert unites this species with $I$. pelagica Leach under the name I. Balthica (Pallas), and in this he may be right, but not being able to consult Pallas' work, I have preferred to use the earliest name that I could certainly comnect with the species, rather than to introduce further confusion by adopting a name of the applicability of which I could not satisfy myself. M. Sars also regarled $I$. pelagica Leach as synonymous with $I$. tricuspirlata, and says it is found as far north as Tromsoe and southward to the Nediterranean, from which statements I conclude that he intended the present species.

This species is fornd along the whole coast of New England! and extends southward along the const of New Jersey at least as far as Great Egg Harbor! and northward to Nova Scotia! and the Gulf of St. Lawrence, where it has been collected by Mr. J. F. Whiteaves. From Cape Cod sonthward it is abuulant, but toward the north it is, mostly replaced by I.phosphorea. It is commonly found among sea-weed along the rocky shores of bays and sounds or among the rocks, where its variety of colors affords it protection. It is also found far from land, attached to floating sea-weed, and was thus taken by Professor S. I. Smith and the writer on George's Banks!, September 14 and 15, 1872, at about $41^{\circ} \mathrm{N}$. lat., $65^{\circ} \mathrm{W}$. lon. One of these specimens was quite large, measuring $38^{\mathrm{mm}}$ in length, but most of them were of moderate size or small. Young individuals are often taken at the surface. According to Enropean anthors it is common on the shores of Great Britain and Ireland (B. \& W.); on all the shores of the North Sea (Metzger et al.); (I. pelagica) as far north as Tromsoe (M. Sars); in the Baltic, the Mediterranean, the Adriatic (Heller, Stalio, et al.), the Black (Czerniarski et $a l$.) and the Caspian ("Eichwald") Seas, and, as with us, is of rariable color and varies also somewhat in the shape of the termination of the pleon, which is, however, more or less three-toothed.

Specimens examined.

\begin{tabular}{|c|c|c|c|c|c|c|c|}
\hline 苟 & Locality. & 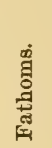 & Bottom. & $\begin{array}{l}\text { When col- } \\
\text { lected. }\end{array}$ & Received from- & 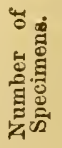 & $\begin{array}{l}\text { Dry. } \\
\text { Alo. }\end{array}$ \\
\hline 1078 & FireIsland Beach, L. I. & & &,-- 1870 & S. I. Smith .. & 50 & Alc. \\
\hline $\begin{array}{l}1079 \\
1954\end{array}$ & 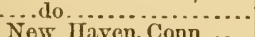 & & & $-\frac{1870}{5-187}$ & $\ldots$ do & 9 & Glyo. \\
\hline 1955 & Stony Creek. Conn..... & & & Oet. 23,1874 & A. E. do erru. & 00 & $\begin{array}{l}\text { Alc. } \\
\text { Alc. }\end{array}$ \\
\hline 1958 & Lyme, Conn ............... & & & & D. C. Eaton... & 2 & Alc. \\
\hline 1963 & $\begin{array}{l}\text { Long Island Sound, } \\
\text { off Saybrook, Conn. }\end{array}$ & 4 & Sand & Aug. 3,1874 & U.S. Fish Com. & 2 & Alc. \\
\hline $\begin{array}{l}1964 \\
1959\end{array}$ & $\begin{array}{l}\text { Off Stonington, Conn... } \\
\text { Noank Harbor, Conn .. }\end{array}$ & 5 & Sand and gravel. & $\begin{array}{l}\text { Aug. } 14,1874 \\
\text { Julv 13,1874 }\end{array}$ & $\mid \ldots$ do $\ldots$ & $\begin{array}{l}12 \\
30\end{array}$ & $\begin{array}{l}\text { Ala. } \\
\text { Ala }\end{array}$ \\
\hline
\end{tabular}


Specimens examined-Continued.

\begin{tabular}{|c|c|c|c|c|c|c|c|}
\hline$\frac{\stackrel{5}{8}}{\stackrel{8}{\Xi}}$ & Locality. & 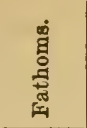 & Bottom. & $\begin{array}{l}\text { Whon col- } \\
\text { lected. }\end{array}$ & $\begin{array}{l}\text { Received } \\
\text { from- }\end{array}$ & 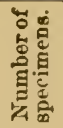 & $\begin{array}{l}\text { Dry. } \\
\text { Alo. }\end{array}$ \\
\hline 1960 & Noank Harbor, Conn.. & & bl-grass ........ & Aug. 28, 1874 & U.S. Fish Com. & 3 & Alo. \\
\hline & Fisher's Island ........ & & 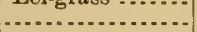 & 2ug. 20,1874 & ....do....... & 8 & Alo. \\
\hline 1962 & Watch II ill, I & & & Oct. -1872 & D. C. Eaton. & 2 & Ala \\
\hline 1965 & Vineyard Sound Mass . & Sf. & n................. &,-- 1875 & U.S. Fish Com. & 1 & Alo. \\
\hline 1966 & ... do do................... & ........ & ........ & $\overline{7}-1875$ & . . do ......... & 7 & Alc. \\
\hline 2153 & Pr...do ..... & 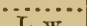 & & Oct. 24,1875 & ¿..do .......... & 00 & Alo. \\
\hline 1968 & 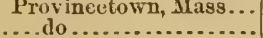 & s. W. & Shorc............ & Aug. $=, 1872$ & $\begin{array}{l}\text { Smith \& Harger } \\
\text { U.S. Fish Com }\end{array}$ & $\begin{array}{r}2 \\
00\end{array}$ & Alo. \\
\hline \multirow{5}{*}{426} & ....do do.................. & L. w. & (a................ & Aug. - , 1879 & . . . do ......... & 00 & Alo. \\
\hline & - & Sf. & Eel.gras & $\begin{array}{l}\text { Aug. }-, 1879 \\
\text { Sept. } 4,1879\end{array}$ & $\begin{array}{l}\text {.... do do } \\
\ldots \text {. do }\end{array}$ & $\begin{array}{l}00 \\
10\end{array}$ & Alc. \\
\hline & Beverly, Mass......... & ........ & & & A. E. Ver & 8 & Alc. \\
\hline & $\begin{array}{l}\text { Gloucester, Mass...... } \\
\text { Gloucester, Jiass., } \\
\text { Outer Harbor. }\end{array}$ & $7-10$ & $\begin{array}{l}\text { Tide-pool ....... } \\
\text { Sand, red algre.. }\end{array}$ & $\begin{array}{r}-, 1878 \\
-\quad, 1878\end{array}$ & $\begin{array}{c}\text { U.S. Fish Com. } \\
\text {.... do ............ }\end{array}$ & 2 & $\begin{array}{l}\text { Alo. } \\
\text { Alo. }\end{array}$ \\
\hline & $\begin{array}{l}\text { Between Boon Island } \\
\text { and Matinicus Rocks. } \\
\text { Casco May. Me........ }\end{array}$ & & &,-- 1878 & $\begin{array}{l}\text { Capt.G.H.MIar. } \\
\text { tin. }\end{array}$ & 5 & Alo. \\
\hline 1975 & Casco Bay, Ram I ..... & \multirow{3}{*}{$\begin{array}{l}\text { L. w. } \\
\text { Sf. } \\
\text { L.w. \& } \\
\text { sf. }\end{array}$} & & $=-1873$ & $\begin{array}{l}\text { U.S. Fi } \\
\text {....do. }\end{array}$ & 4 & $\begin{array}{l}\text { Alo. } \\
\text { Alo. }\end{array}$ \\
\hline 2150 & George's Bank......... . & & -....... & Sept. -1872 & Smith \& Harger & 6 & Alo. \\
\hline 1977 & Bay of Fundy .............. & & & $--1,1$ & U.S. Fish Com. & 2 & Alo. \\
\hline 1978 & Off Halifax & & &,- 1877 & $\ldots$. & 1 & Alo. \\
\hline 1979 & Nova Scotia ............... & & & - & $\ddot{p o n}$ & & \\
\hline & & & & & man. & & \\
\hline & & & & & $\begin{array}{l}\mathcal{J} \text { ardin } \mathrm{des} \\
\text { Plantes. }\end{array}$ & 1 & Alt \\
\hline
\end{tabular}

Idotea phosphorea Harger.

Idotea phosphorea Harger, This Report, part i, p. 569 (275), 1874; Proc. U. S. Nat. Mus., 1879, vol. ii, p. 160, 1879.

Verrill, Am. Jour. Sci., III, vol. vii, pp. 43, 45, 131, 1874; Proc. Amer. Assoc., 1873, pp. 362, 367, 369, 1874; This Report, part i, p. 316 (22), 1874.

Whiteaves, Am. Jour. Sci., III, vol. vii, p. 218, 1874; Further Deep-sea Dredging, Gulf of St. Lawrence, p. 15, "1874."

Plate V, Figs. 27-29.

This species may be distinguished from the others on this coast by the pointed abdomen or pleon. Young individuals sometimes ro. semble the young of $I$. irrorata, but may still be clistinguished by the epimeral sutures of the second and third thoracic segments, which do not entirely cross the segment, but allow more or less of the posterior part of the edge of the segment to form a part of the margin of the animal as seen from abore. From Synidoten nodulosa it may be distinguished by the evident epimeral sutures and by the three acute teeth at the base of the pleon on each side, instead of a single obtuse tooth, as in that species. For characters separating it from the other Isopola of the coast see at the close of the description of the genus.

The botly, especially of the young, is rough and tubereular along the median line and often also laterally. Older specimens are much smoother, losing their' large median tubercles but never becoming as smooth as in the preceding species. The head is narrowed behind. The eyes are of moderate size. The flagellum of the antennæ (pl. V, fig. $28 a$ ) is shorter than 
the peduncle, and consists of about ten to fourteen segments. The maxillipeds (pl. V, fig. $28 b$ ) have the external lamella $(l)$ broader than in the preceding species, with its inner margin straight and its onter margin curving pretty regularly to a slightly attenuated tip.

The epimera of the second, third, and fourth pairs are rounded behind, and those of the last three pairs are less acute than in $I$. ivorata.

Pleon ovate, a little constricted near the middle and pointed, its three proximal segments rather less acute than in the preceding species. The basal plate of the operculnm (pl. V, fig. $28 e$ ) tapers toward the end, and the terminal plate is triangular, a little longer than broad. The stylet on the second pair of pleopods in the male (pl. V, fig. $29 s$ and $s^{\prime}$ ) is slender, nearly straight, surpasses the lamella to which it is attached, and is obliquely truncate.

Length $25^{\mathrm{mm}}$; breadth $7^{\mathrm{mm}}$. The color is very varied, usually dark green or brownish, with patches of yellow or whitish, transversely or obliquely arranged. I have never observed a striped pattern of coloration, so common in I. irrorata, and it must oceur very rarely if at all. The color is usually darker than in that species.

This species is found associated with the last among rocks and seaweed along the entire coast of New England! and extends northward to Halifax!, Nova Scotia, and the Gulf of St. Lawrence!. It appears to be a more worthern species than $I$. irrorata, as it is comparatively rare sonth of Cape Cod, while it is abundant in Casco Bay, Maine, and in the Bay of Fundy.

Specimens examined.

\begin{tabular}{|c|c|c|c|c|c|c|c|c|}
\hline \multirow{2}{*}{$\begin{array}{l}\text { 芯 } \\
\text { 息 } \\
\text { 丢 }\end{array}$} & \multirow{2}{*}{ Locality. } & \multirow{2}{*}{ 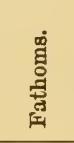 } & \multirow{2}{*}{ Bottom. } & \multirow{2}{*}{$\begin{array}{l}\text { When col- } \\
\text { lected. }\end{array}$} & \multirow{2}{*}{ Receivedfrom- } & \multicolumn{2}{|c|}{$\begin{array}{l}\text { Speci- } \\
\text { mens. }\end{array}$} & \multirow{2}{*}{$\begin{array}{l}\text { Dry. } \\
\text { Alo. }\end{array}$} \\
\hline & & & & & & No. & Sex. & \\
\hline 1980 & $\begin{array}{l}\text { South End, Now Ha- } \\
\text { ven, Conn. }\end{array}$ & & & Nor.,- 1874 & A. E. Verrill.. & .. & & Ala \\
\hline 1981 & Stony Creek, Conn.. & & & Sept. 23,1874 & do & & & Alc. \\
\hline $\begin{array}{l}1983 \\
1984\end{array}$ & $\begin{array}{l}\text { Off Saybrook, Conn - } \\
\text { Long Island Sound . }\end{array}$ & 4 & Sand. & Aung. 3, 1874 & U. S. Fish Com. & 3 & $\mathrm{Y}$ & Alo. \\
\hline 1985 & South I'isher's Isl- & 9 & 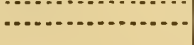 & Aug. 21, 1874 & ...do ... & i & & Alc. \\
\hline 1987 & $\begin{array}{l}\text { Vinesard Sound, } \\
\text { Mass. }\end{array}$ & & &,-- 1871 & .... do ... & & & Ala. \\
\hline $\begin{array}{l}1986 \\
2147\end{array}$ & 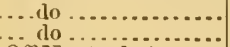 & & & --1872 & $\mid \begin{array}{l}\mid . \text { do } \ldots . \\
\ldots \text {... do } \ldots .\end{array}$ & 1 & & $\begin{array}{l}\text { Ala. } \\
\text { Alc. }\end{array}$ \\
\hline 1990 & $\begin{array}{l}\text { Off Nantucliet...... } \\
\text { Capo Cod Bay...... }\end{array}$ & $\begin{array}{l}15 \\
14\end{array}$ & 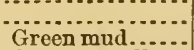 & $\begin{array}{l}\text { Sept. 8 } 1875 \\
\text { Sept. 15, } 1879\end{array}$ & U. S. Fish Com & 1 & y. & $\begin{array}{l}\text { Alco } \\
\text { Alc. }\end{array}$ \\
\hline 144 & Nahant, Mass........ & 7 & $\begin{array}{c}\text { Coarse } \\
\text { sand. }\end{array}$ & Sept. 15, 1879 & ....do ........... & 3 & & Alc. \\
\hline & $\begin{array}{l}\text { Gloucester, Mass... } \\
\text { Ten Pound Island, } \\
\text { Gloucester, Mass. }\end{array}$ & $7-10$ & Sand and algæ.. & $=, 1878$ & U. S. Fish Com. & 00 & రீ 95. & $\begin{array}{l}\text { Alc. } \\
\text { Ala. }\end{array}$ \\
\hline $\begin{array}{l}1991 \\
1992\end{array}$ & $\begin{array}{l}\text { Annisquam, Mass... } \\
\text { Casco Lay, Me...... }\end{array}$ & Sit. & & Aug. 4,1878 & A. Hyatt ....... & $\begin{array}{r}20 \\
1\end{array}$ & $\dddot{\mathrm{g}}$ & Alo. \\
\hline 1993 & $\begin{array}{l}\text { Casco Bay, Ram } \\
\text { Island. }\end{array}$ & L. w. & &,-- 1873 & ...do ................ & 4 & $\cdots \cdots$ & Ala. \\
\hline 1994 & $\begin{array}{l}\text { Bay of Fundy ...... } \\
\text { Bay of Fuudy, whit- } \\
\text { ing River. }\end{array}$ & & & $=$ 二, 1872 & 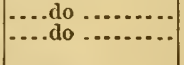 & $\begin{array}{l}1 \\
00\end{array}$ & $8^{+}+$ & $\frac{\text { Alo. }}{\text { Ala }}$ \\
\hline & $\begin{array}{l}\text { Off Halifax, N. S } \\
\text { Egmont Bank, Gulf }\end{array}$ & 18 & & {$\left[\begin{array}{r}-, 1877 \\
-, 1873\end{array}\right.$} & J.F. Whiteaves. & $\begin{array}{l}2 \\
1\end{array}$ & $(\cdots \cdots \cdot \mid$ & Ala. \\
\hline & & & & & & & & \\
\hline
\end{tabular}


Iđotea robusta Kröyer.

IIdotea metallica Bose, Hist. nat. des Crust., tom. ii, p. 179, pl. 15, fig. 6, 1802.

Idothea robusta Kröjer, Naturhist. Tidssk., II, B. ii, p. 108, 1846; Voy. on Scand., Crust., pl. 26, fig. 3, "1849."

Reinhardt, Grönlands Krebsdyr, p. 35, 1857.

Stimpson, Proc. Acad. Nat. Sci., 1862, p. 133, 1862.

Verrill, Ain. Jour. Sci., III, vol. ii, p. 360, 1871; This Report, part i, p. 439 (145), 1874 (Idotea).

Harger, This Report, part i, p. 569 (275), pl. v, fig. 24, 1874; Proc. U. S. Nat. Mus., 1879, vol. ii, p. 160, 1879 (Idotea).

Litken, Crustacea of Greenland, p. 150, note, 1875.

Plate VI, Figs. 30-32.

This species is easily recognized within the genus by the pleon, which is broadly truncate at the apex and not at all pointed. The pleon is also large and more swollen above than in the other species. For characters. separating it from other Isopoda, see near the close of the generic description.

The entire upper surface, except perhaps that of the pleon, is somewhat rugose. The head is nearly square, with the eyes large and prominent. The antenuæ (pl. VI, fig. 31 ) have the second segment large, the flagellum short, usually of less than ten articulations. Under a sufficient power these organs are seen to be clothed with a very fine close pubes. cence, which also occurs in a less degree upon the legs. The maxillipeds. (pl. VI, fig. $32 a$ ) have the external lamella (l) short and oval.

The legs are robust and spiny. The epimera, projecting, give a serrated appearance to the sides of the thorax, as seen in figure 30 , plate VI, and the dorsum is more convex than in the other species.

The pleon is large and convex, its sides are nearly parallel beyond the middle, and it is broadly truncate, or eren somewhat emarginate, at the apex. The basal plate of the operculum (pl. VI, fig. 31c) is elongated, with parallel sides; the terminal plate less than one-fourth as long and nearly square, but tapering slightly and somewhat broader than long. The male stylet on the second pair of pleopods (pl. VI, fig. $32 c, s$ ) reaches. the end of the lamella, to which it is attached, and is slightly curved and rounded at the tip.

Length of male $28^{\mathrm{mm}}$; female $22^{\mathrm{mm}}$; breadth $9^{\mathrm{mm}}$. Color bright blue or green above when alive, becoming darker and dull in alcohol, without the markings of the other species, but often with metallic reflections, when seen in the water, where it is commonly taken swimming free or among masses of floating sea-weed.

It is thus found in mid-ocean, and was described by Kröyer from specimens taken in about $60^{\circ}$ north latitude between Iceland and Greenland. It was taken in consilerable abundance at Fire Island Beach!, on the south shore of Long Island, by Professor S. I. Smith in 1870; also by the U. S. Fish Commission at Vineyard Sound!, Mass., often in company with I. irrorata Edw.; at George's Banks!, September, 1872, small specimens, $5^{\mathrm{mm}}$ in length; between Boon Island and Matinicus Rocks, near the 
Isles of Shoals!, by Capt. G. H. Martin, of the schooner 'Northern Eagle' in 1878, and at Halifax!, Nova Scotia, by the U. S. Fish Commission in 1877, whence it extends to at least $60^{\circ}$ north latitude.

The figure and description of Idotea metallica given by Bose correspond well with small specimens of this species such as were taken by Professor S. I. Smith and the writer on George's Bauks, and the locality he gives, "the high seas," corresponds also with the habit of this species, so that I an inclined to think that his name ought to be restored. I have, however, retained Kröyer's name, since he so thoroughly described and so well figured the species as to leave no doubt of its identity.

Specimens examined.

\begin{tabular}{|c|c|c|c|c|c|c|c|}
\hline \multirow{2}{*}{ 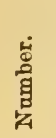 } & \multirow{2}{*}{ Locality. } & \multirow{2}{*}{ Habitat. } & \multirow{2}{*}{$\begin{array}{l}\text { When col- } \\
\text { lected. }\end{array}$} & \multirow{2}{*}{ Received from- } & \multicolumn{2}{|c|}{$\begin{array}{l}\text { Speci- } \\
\text { mens. }\end{array}$} & \multirow{2}{*}{$\begin{array}{l}\text { Dry. } \\
\text { Alc. }\end{array}$} \\
\hline & & & & & No. & Sex. & \\
\hline 1080 & Firo Island Beach, Long Island ... & Surface.... & -1870 & S. I. Smith..... & 46 & 89 & Alo. \\
\hline 1998 & Vineyard Sound, Mass.............. & Surface.... & -1875 & U.S. Fish Com. & 1 & & Alc. \\
\hline 1999 & . & Surface.... & & ....do .......... & 00 & dீ? & Alo. \\
\hline 2002 & . . do & Surface.... & July 14,1871 & $\ldots$ do $\ldots . . . . .$. . & 2 & ..... & Alc. \\
\hline 2003 & ....do . & Surfaco.... & Oct. 24,1875 & V.N. Edwards & 00 & $\ldots$. & Alo. \\
\hline 2004 & . do do & Surface.... & Nov. 16,1875 & ....do ........... & 00 & ..... & Alc. \\
\hline 2000 & George's Bank. .................... & Surface.... & Sept.,- 1872 & Smith \& Harger & 4 & y. & Alo. \\
\hline 2001 & 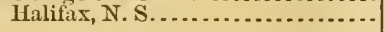 & Surface.... &,- 1877 & U. S. Fish Com. & 1 & & Alc. \\
\hline
\end{tabular}

Synidotea Harger.

Synidotea Harger, Am. Jour. Sci., III, vol. xv, p. 374, 1878.

Antennæ with an articulated flagellum; epimeral sutures not evident above; pleon apparently composed of two seginents, united above but separated at the sides by short incisions; operculum with a single apical plate; palpus of maxillipeds three-jointerl.

Of the two species that I had referred to this genus I had been able to examine only the first when this paper was placed in the hands of the printer. Two specimens of the second species were collected during the summer of 1879, and an examination of their characters leares no doubt of their generic affinity. Except in the particnlars abore specified the description already given of the genus Idotea will in general apply also to the present, but the species are characterized by a firmer and more solid structure, the segments being more closely articnlated and the integument having a somewhat shelly appearance. The pleon is further consoliclated than in that genus, the only trace of its composite nature, as seen from above, being a slight incision on each side near the base and ruming up somewhat obliquely toward the dorsal surface. The welldereloped and distinctly articulated flagellum of the antennæ serres easily to distinguish the species from those of the following genera of the family. 
Bynidotea nodulosa Harger (Kröjer).

Idothea nodulosa Krö̈yer, Naturhist. Tidssk., II, B. ii, p. 100, 1846; Voy. en Scand., Crust., pl. 26, fig. 2, 1849.

Reinhardt, Gronlands Krebsiyr, p. 34, 1857.

Liitken, Crust. Greenland, p. 150, "1875."

Symidotea nodulosa Harger, Am. Jour. Sci., III, vol. xv, p. 374, 1878; Proc. U. S. Nat. Mus., 1879 , vol. ii, p. 160, 1879.

\section{Plate VI, Figs. 3:3-35.}

This speeies may be recognized most easily by the pleon, which is entire, except for a slight incision near the base on each side, and tapers to a blunt but not at all bifid point. The articulated flagellum of the antenna distinguishes it from Erichsonia.

'The head and body are ronghened and tuberenlar, lıving a prominent median row of tubercles and coarse rugie along the sides of the thorax. The head has a median noteh in front, and immediately above this a prominent tuberele directed forward, and succeeded on the median line by two less prominent tubereles. In front of each eye is a still larger tuberele, directed forward and projecting over the anterior margin of the head; behind and within, there are two smaller oval tubercles. The eyes are large, convex, and rery prominent. The peduncular segments of the antennæ (pl. VI, fig. 34 b) increase gradually in length from the first and decrease in diameter from the seeond, which lacks the lateral incision seen in Idotea. The flagellum is distinctly articulated, with about nine segments, of which the last two are very minnte. The maxillipeds (pl. VI, fig. 35 a) have the external lamella (l) of an irregular shape, emarginate on the inner side and obtusely pointed. The outer maxilla (pl. VI, fig. $35 b$ ) are armed on their external lobe with strong, curved, peetinated setre, which become much elongated and stont at the tip of the lobe. The inner maxillæ (pl. VI, fig. $35 \mathrm{c}$ ) resemble these organs in other members of the family.

The first four thoracic segments have their external margins rounded. In the last three the margins are more nearly straight, but with ronnded angles. The first pair of legs (pl. VI, fig. $34 c$ ) are much shorter than the second, and the propodus in the first pair is bristly on what is, in the ordinary position, the upper side.

The pleon is short, and tapers from the base. It is convex, bears two or three small tubercles on the median line near the base, and an impressed transverse line in continuation of the short lateral incisions. The basal plate of the operculum (pl. VI, fig. $34 d$ ) is oblique at the base with rounded angles, and is somewhat vanlted, with an oblique elevation extending from the articnlation to the inmer distal angle. The inner margin is straight, and the cuter parallel with it to near the end. The terminal plate is slightly oblinue at the base, and is elongated triangular, about twice as long as broad. 'The free margins are finely eiliated, except at and near the base, and the inmer margin of the basal plate bears also scattered stouter hairs. The stylet of the males on the second pair of pleopods (pl. VI, fig. $35 d, s)$ is longer and stouter than in any of our species 
of Idotea. It is nearly twice the length of the lamella, to which it is attached, and of an elongated spatulate form tapering to an obtuse point. The lamella are provided with but few cilia, which extend less than half the way from the end of the lamella to the end of the stylet.

Length $10.5^{\mathrm{mm}}$; breadth $3.5^{\mathrm{mm}}$. Females proportionally broader; length . $^{. \mathrm{mm}}$; breadth $3^{\mathrm{mm}}$. Color in aleohol gray, often with brownish transverse marlings.

This species seems to agree with Idotea nodulosa Kröyer, from Southern Greenland, as described and figured, except that the epimeral sutures are not evident above; the lateral margins of the segments are, however, somewhat thickened and prominent with rugæ, as shown in his figure, and $I$ hare no doubt that it is the same as his species. It was dredged off Halifax! by the Fish Commission at several localities in the summer of 1877 , in from 16 to 190 fathoms on sandy and rocky bottoms, with red algæ at one locality. A specimen was brought from George's Banks! by Mr. Joseph P. Sehemelia, of the sehooner ' Wm. H. Raymond,' in the summer of 1879, and Mr. J. F. Whiteares has sent to the Museum for examination two specimens collected by Mr. G. M. Dawson, in 111 fathoms, Dixon Entrance!, north of Queen Charlotte Island, British Columbia. The range of the species would therefore be, as at present known, from George's Banks to Greenland and the Aretic Seas, and southward on the Pacific coast as far as British Columbia..

Specimens examined.

\begin{tabular}{|c|c|c|c|c|c|c|c|c|}
\hline \multirow{2}{*}{ 点 } & \multirow{2}{*}{ Locality. } & \multirow{2}{*}{ 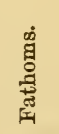 } & \multirow{2}{*}{ Bottom. } & \multirow{2}{*}{$\begin{array}{l}\text { When col- } \\
\text { lected. }\end{array}$} & \multirow{2}{*}{ Received from- } & \multicolumn{2}{|c|}{$\begin{array}{l}\text { Speci. } \\
\text { mens. }\end{array}$} & \multirow{2}{*}{$\begin{array}{l}\text { Dry. } \\
\text { Alc. }\end{array}$} \\
\hline & & & & & & No. & Sex. & \\
\hline & $\begin{array}{l}\text { Dixon Entrance, Q. } \\
\text { C. I. }\end{array}$ & 111 & & & J. F. Whiteaves & 2 & & Alc. \\
\hline 2006 & Off Halifax, N.S.... & 16 & Stones, sand, red &,-- 1877 & U.S. Fish Com. & 2 & & Alc. \\
\hline 2007 & $\begin{array}{l}\text { South of Halifax, } 120 \\
\text { miles. }\end{array}$ & 190 & $\begin{array}{l}\text { Gravel and peb- } \\
\text { bles. }\end{array}$ & Sept. 1,1877 & .... do ........... & 1 & $q$ & Alc. \\
\hline 2008 & 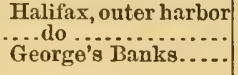 & $\begin{array}{l}18 \\
16\end{array}$ & $\begin{array}{l}\text { Sand, stones .... } \\
\text { Rocks, nullipore }\end{array}$ & $\begin{array}{l}\text { Sept. } 4,1877 \\
\text { Sept. 4, } 1877 \\
-, 1879\end{array}$ & J. P. Schemelia & $\begin{array}{l}2 \\
1 \\
1\end{array}$ & $q^{\prime}$ & $\begin{array}{l}\text { Alc. } \\
\text { Alc. } \\
\text { Alc. }\end{array}$ \\
\hline
\end{tabular}

Synidotea bicuspida Harger (Owen).

Idotea bicuspida Owen, Crustacea of the Blossom, p. 92, pl. xxvii, fig. 6, 1839.

Strects and Kingsley, Proc. Essex Inst., vol. ix, p. 108, 1877.

Idotea marmorata Packard, Mem. Bost. Soc. Nat. Hist., vol. i, p. 296, pl. viii, fig. $6,186 \%$.

Whiteaves, Further Deep-sea Dredging in Gulf of St. Lawrence, p. 15, 1874. Idotea pulehra Lockington, Proc. Cal. Acad. Sci., vol vii, p. 45, 1877.

Synidotea bicuspida Harger, Proc. U. S. Nat. Mus., 1879, vol. ii, p. 160, 1879.

This species may be most easily reeognized among the known Isopoda of our coast by the form of the pleon, which is nearly triangular in shape, marked by a slight incision at each side near the base, and distinctly bicuspid at the tip. 
The body is rather more robust than in the last species, the length being only about two and a half times the breadth, and is peeuliarly marked above by depressed and mostly eurved lines, varying in length but mostly short, and confined principally to a region on each side of the median line and extending across the head but not the pleon.

The head is broadly emarginate in front, with a median notch, and its antero-lateral angles are prominent. The ejes are at the widlest part of the head, and are strongly convex. The posterior outline of the head is nearly in the form of three sides of a hexagon. The antennula attain about the middle of the fourth antennal segment. The antenire are about one-half as long as the body. The first two antennal segments are short and apparently articnlated so as to admit of but little motion; the third segment is a little longer than the first two taken together, and is the largest of the antennal segments in diameter; the fourth segment is somewhat longer than the third, and the fifth or last perluncular segment is the longest, and is followed by a flagellum, a little shorter than the peduncle and composed of abont fourteen segments. The last three peduncular segments of the antennæe are somewhat bristly hairy. The maxillipeds are nearly as in the preeeding species. The outer maxillæ are destitute of the elongated, peetinate setæ fonnd in that species.

The thoracic segments rary but little in length measured along the median line, but the fifth, sixth, and seventh are slightly shorter than the preceding ones, and this difference is still greater measured along the margins of the segments, where the first is longest, the next three about equal, and the last three shorter. The legs are robust, the first pair shortest, and all more or less bristly hairy. The lateral margins of the segments are much less rounded than in $S$. nodulosa.

The pleon is short, the length being scarcely greater than the breadth at base; above, it is nearly smooth, the impressed lines, so conspicuous in the lateral region of the thorax, being continued for but a slight distance upon its surface. The incision at each side near the base is continued upward and formard by a depressed line on each side; the lateral margins are gently conrex to near the tip, which is distinctly bicuspid. The basal plate of the opereulum is trarersed obliquely by a longitndinal ridge on the external surface, and is rounded in front, slightly narrowed behind, and bears a short, triangular, terminal plate, its length being but little greater than its breadth.

Length $15.5^{\mathrm{mm}}$; breadth $6^{\mathrm{rm}}$. Color in alcohol grayish, with white cloudings. Lockington says: "When recent, the coloration of this species is very beautiful, consisting of red eloudings on a lighter ground."

There seems to be no donbt in regard to the synonymy of this speeies as published by Streets and Kingsley, adopted by the writer in a prerious publication, and given above.

The only specimens that I have examined were two, bronght from the Grand Banks!, in the summer of 1879 , by Mr. Charles Ruckley, of the 
schooner 'Frederick Gerring, jr.', Capt. Edwin Morris. Dr. Packard's locality is "Sloop Harbor, Kynetarbuck Bay [Labrador], seven fathoms on a sandy bottom." Whiteaves records the species from Orphan Bank, Gulf of Saint Lawrence. Lockington's specimens were collected on the "west coast of Alaska, N. of Behring's Strait, by W. J. Fisher, naturalist of the U. S. S. Tusearora, Deep-Sea Sounding Expedition." Owen's locality is "the Arctic Seas."

\section{Erichsonia Dana.}

Erichsonia Dana, Am. Jour. Sci., II, vol. viii, p. 427, 1849.

Antennæ six-jointed, the terminal or flagellar segment not articulated, clarate; palpus of the maxillipeds four-jointed; legs all nearly alike, prehensile or sub-prehensile; pleon with its segments consolidated into a single piece.

This genus is represented within our limits by two well-marked species, which further agree in the following characters: The head is quadrate, with the eyes lateral. The antennulx are short, not surpassing the third segment of the antennæ. The antennæ are well developed, more than half as long as the body, with a very short basal segment articulated with little or no motion to the second segment, which is two or three times as long as, and of greater diameter than the first. It is, as usual in the family, incised at its distal end on the under surface. The next three segments are nearly cylindrical. The last or flagellar segment is the longest, and is slightly clavate.

The legs are all terminated by a prehensile or sub-prehensile hand, the dactylus being eapable of considerable or complete flexion on the more or less swollen propodus. This flexion is most complete in the first pair. The first two pairs of legs arise near the anterior margin of the segments to which they belong. The place of attachment to the segment moves gradually backward in the following pairs until the last two pairs arise near the posterior margin of the last two segments. The epimera are more or less evident from above, at least in the last two segments.

The pleon constitutes about one-third the length of the body, and is consolidated into a single piece; it bears a more or less evident tooth on each side near the base, and is dilated and obtusely triangular at the apex. The basal plate of the opereulum is oblique at the anterior end and abruptly narrowed posteriorly, where it bears a densely plumose bristle, as in Idotea; the terminal plate is triangular. The stylet on the second pair of pleopods in the males is well developed, surpassing the cilia; it is minutely denticulated or spinulose near the end and very acute.

The two species found on our coast have but a slight external resemblance to each other, and may be distinguished at a glance, as will be seen from the specific descriptions, and from the figures (pl. VI, fig. 36, and pl. VII, fig. 38). The long, clavate terminal segment of the antennro 
distinguishes them at once from young specimens of Idotea, especially I. phosphorea, which sometimes resemble E. filiformis. This character of the antemnæ serves, indeed, to distinguish the two unlike representatives of the present genus from all the other Isopoda of our coast.

Erichsonia filiformis Harger (Say).

Stenosoma filiformis Say, Jour. Acall. Nat. Sci., vol. i, p. 424, 1818.

Edwards, Hist. nat. des Crust., tom. iii, p. 134, 1840.

Dekay, Zool. Now York, Crust., p. 44, 1844.

Idotea filiformis White, List Crust. Brit. Mus., p. 95, 1847.

Erichsonia filiformis Harger, This Report, part i, p. 570 (276), pl. vi, fig. 26, 1874; Proc. U. S. Nat. Mus., 1879, vol. ii, p. 160, 1879.

Verrill, This Report, part i, p. 316 (22), 1874.

Plate VII, Figs. 38-41.

This species may be at once distinguished from the following by the strongly serrated outline of the sides, as seen from above. The clavate terminal segment of the antenna distinguishes it from the other known Isopoda of our coast.

The body is slender and elongated, but less so than in the next species, the sides are nearly parallel and there is a median row of prominent tubereles, one, large and bifid, on the head, and one upon each thoracic segment. The ejes are prominent. The antennulæ (pl. VII, fig. 39 a) surpass the middle of the third antennal segment. The first segment of the antennæ (pl. VII, fig. $39 \mathrm{~b}$ ) is very short; the terminal segment is bristly hairy toward the apex. The external lamella of the maxillipeds (pl. VII, fig. $41 a$ ) is emarginate on the outer side toward the apex.

The thoracic segments each bear a prominent median tuberele near their posterior margins, and the first bears also a smaller tubercle near its anterior margin. In the first two segments the posterior external angles are salient and much elevated. The angulated epimera are evident from above in front of these projections. In the third and fourth segments both lateral angles are salient but not elevated. In the last three segments, only the anterior angles are produced, but the epimera fill the places of the posterior angles. This arrangement gives the appearance of fourteen teeth upon each side of the thorax, and the prominent divergent tooth on the pleon makes, in all, fifteen.

The operculum (pl. VII, fig. $39 d$ ) is a little inore vaulted than in the next species and shorter; the basal plate is less than three times as long as broad; the terminal plate is triangular. The stylet on the second pair of pleopods in the male (pl. VII, fig. $41 \mathrm{l}, s$ ) is slightly eurved, finely spinulose near the apex on the side toward the lamella, and minutely and sharply denticulate on the opposite side at the apex, as shown in the enlarged figure $\left(s^{\prime}\right)$ of the distal portion of the stylet.

Length $11^{\mathrm{mm}}$; breadth $3.4^{\mathrm{mm}}$. The color is a usually dull neutral tint without bright markings, but sometimes more or less variegated with brown or reddish, fading in alcohol. 
This species was originally described from Great Egg Harbor, Now Jersey, where Say found it in company with Idotea irrorata. It is not uncommon along the shores of Long Island Sound! and as far east as Vineyard Sound, Mass.! but has not yet been found north of Cape Cod. It is usually found in tide-pools or among eel-grass and algx, and has been taken from a depth of 7 fathoms.

Specimens examined.

\begin{tabular}{|c|c|c|c|c|c|c|c|}
\hline$\frac{\dot{s}}{\stackrel{0}{0}}$ & Locality. & 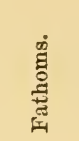 & Bottom. & $\begin{array}{l}\text { When col- } \\
\text { lected. }\end{array}$ & Receivedfrom- & 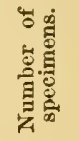 & $\begin{array}{l}\text { Dry. } \\
\text { Alc. }\end{array}$ \\
\hline 2010 & Long Island Sound.. & & & & & 00 & Alc. \\
\hline 2011 & Thimble Islands .... & & & & A. E. Verrill... & & Alc. \\
\hline 2012 & $\begin{array}{l}\text { Long Island Sound, } \\
\text { Fisher's Is land } \\
\text { Sound. }\end{array}$ & 7 & Sand and shells &,- 1874 & U.S. Fish Com. & 1 & Alc. \\
\hline 2013 & Long Island Sound. . & $4 \frac{1}{2}$ & Sand and gravel. &,-- 1874 & .... do ......... & 2 & Alc. \\
\hline 2014 & ....do .............. & $\ldots . . .$. & ............... &,- 1874 & . . do $\ldots . . . .$. & i & Alc. \\
\hline 2015 & 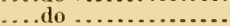 & ........ & ............... & Sept. 10,1874 & ... do .......... & 2 & Alc. \\
\hline 2016 & Noank ............... & ......... & Eel-grass ....... & $-\ldots, 1874$ & ....do & 2 & Alc. \\
\hline 2017 & Vineyard Sound .... & ..... & .................. &,- 1875 & .... do .......... & 2 & Alc. \\
\hline
\end{tabular}

Erichsonia attenuata Harger.

Erichsonia attenuata Harger, This Report, part i, p. 570 (276), pl. vi, fig. 27, 1874 ; Proc. U. S. Nat. Mus., 1879, vol. ii, p. 160, 1879.

Verrill, This Report, part i, p. 370 (76), 1874.

Plates VI and VII, Figs. 36 and 37.

This species is at once distinguished from the preceding by its slender form and regular outline; the clavate antennal flagellum distinguishes it from other Isopoda.

The body is smooth throughout and about six times as long as broad, withont prominent irregularities and narrowly linear in ontline. The eyes are small and black. The antennulæ (pl. VII, fig. $37 a$ ) are short, slightly surpassing the second antennal segment. The antennæ (pl. VII, fig. $37 \mathrm{~b}$ ) are stout and smoother than in the preceding species. The external lamella of the maxillipeds (pl. VII, fig. $37 c, l$ ) is oval and regularly rounded at the tip.

The thoracic segments increase in size to the third, which is equal to the fourth, and the last three are of a gradnally decreasing size. The epimera are nowhere conspicuous, but may usually be seen from above, ispecially in the posterior segments.

The pleon presents only slight traces of a lateral tooth near its base and is but little dilated toward the tip. The operculum (pl. VII, fig. 37 d) is longer than in the preceding species, the basal plate is more than three times as long as broad, the terminal plate elongated trian. gular and obtuse. The male stylet on the second pair of pleopods (pl. VII, fig. $37 e, s$ ) is nearly straight, hardly surpasses the cilia, and is minutely denticulated near the acute apes. 
Length $15^{\mathrm{mm}}$; breadth $2.5^{\mathrm{mm}}$. Alcolıolic specimens are of a light grayish yellow, with minute black punctations.

It was abumdant in eel-grass at Great Egg Harbor, New Jersey! in April, 1871, and has also been found at Noank, Conn.! on eel-grass, but is not common. It has not been found north of Cape Cod.

Specimens examined.

\begin{tabular}{|c|c|c|c|c|c|c|c|c|}
\hline \multirow{2}{*}{ 离 } & \multirow{2}{*}{ Locality. } & \multirow{2}{*}{ 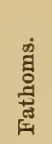 } & \multirow{2}{*}{ Bottom. } & \multirow{2}{*}{$\begin{array}{l}\text { When col- } \\
\text { lected. }\end{array}$} & \multirow{2}{*}{ Rocoived from- } & \multicolumn{2}{|c|}{$\begin{array}{l}\text { Speci- } \\
\text { mens. }\end{array}$} & \multirow{2}{*}{$\begin{array}{l}\text { Dry. } \\
\text { Alo. }\end{array}$} \\
\hline & & & & & & No. & Sex. & \\
\hline 1226 & Great Egg IIarbor, & & Eol-grass ... & Apr.,- 1871 & S. I. Smith..... & 00 & & Alc. \\
\hline 2018 & Noank, Conn ...... & & ....do . &,-- 1874 & U.S. Fish Com. & 1 & 9 & Alc. \\
\hline
\end{tabular}

Epelys Dana.

Epelys Dana, Am. Jour. Sci., II, vol. viii, p. 426, 1849.

Antennæ shorter than the anntennulæ and with only a rudimentary flagellum; palpus of the maxillipeds three-jointed; legs all terminated with prehensile hands; pleon consolidated into a single segment with a basal lobe on each side.

Two small and elosely allied species from this coast have been referred to this genus. They resemble each other very closely and may be at onee recognized by their depressed orate form, very short antennæ, and generally dirty appearance. The form of the body and absence of powerful mandibles distinguish them from the male Gnathia. The length of the body is between two and three times its width. It is markerl by a depressed line on each side, rmuning from the posterior part of the head, across the thoracic segments, nearer to their lateral margins than the median line, except perhaps in the last segment, thence continmed to inclose a prominent hemispherieal protuberance on the anterior part of the pleon, giving the animal somewhat the appearance of a trilobite. The body is slightly roughened under a lens, or sometimes minntely hirsute. The head is slightly dilated at the sides, with the anterior angles pro. duced, and bears a pair of broad, low, triangular tubercles on its anterior part, and a eurved posterior depression. The eyes are lateral aud prominent, the antennulie are longer than the head, surpass the antennæ, and have the basal segment but little enlarged. The antennæe (pl. VIII, fig. $45 \mathrm{~b}$ ) are shorter than the head, not surpassing the third antenunlar segment, the segments increasing in length to the fourth; fifth as long as the fourth, but more slender, bearing a minute, slender rudiment of a flagellum, which is setose at the tip.

The thoracie segments have thick evident margins; first segment smallest, somewhat embracing the head; third and fourth largest; 
last segment curving around the base of the pleon. The epimera are not evident from above. The legs (pl. VIII, fig. $46 a$ ) are slender and all terminated by a slender prehensile hand, of which the finger, or dactylus, becomes almost acicular in some of the posterior pairs. All the legs are more or less hairy.

The pleon bears on each side, near its base, a rounded lobe, which is separated from the large posterior portion by a more or less evident incision. Dorsally it is convex, and presents two hemispherical elevations, the proximal more convex than, but only half as large as, the distal. They are separated by a broad and deep groove, and the distal convexity is contimued upon the obtusely-pointed apex of the pleon. The opereilmm (pl. VIII, fig. $46 \mathrm{~b}$ ) is vanlted; its basal plate is rounded anteriorly, carinate near its inner margin, contracted externally for the distal third of its length and trumeate at the tip, where it bears a stont elongated-triangular finely ciliated terminal piece. The basal plate is coarsely eiliated on its inner margin, and bears a few plumose hairs along its onter free margin. The stylet on the second pair of pleopods in the males is short and stont, surpasses the lamella but not the cilia, and is spinulose just below the blunt apex.

Both species are of a dull neutral color, and commonly covered with particles of mud or other foreign matter. They occur on piles, or under stones, in muddy places, and are dredged on muddy bottoms.

\section{Epelys trilobus Smith (Say).}

Idotea triloba Say, Jour. Acad. Nat. Sci. Phil., vol. i, p. 425, 1818.

Edwards, Hist. nat. des Crust., tome iii, p. 134, 1840.

Dekay, Zool. New York, Crust., p. 43, 1844.

Leidy, Jour. Acad. Nat. Sci., II, vol. iii, p. 150, 1855.

Jaera triloba White, List Crust. Brit. Mus., p. 97, 1847.

Epelys trilobus Smith, This Report, part i, p. 571 (277), pl. vi, fig. 28, 1874.

Verrill, Am. Jour. Sci., III, vol. vii, p. 135, 1874; Proc. Amer. Assoc., 1873, p. 372, 1874; This Report, part i. p. 370 (76), 1874.

Harger, Proc. U. S. Nat. Mus., 1879, vol. ii, p. 160, 1879.

Plate VII, Figs. 42 and 43.

This species may be recognized among our Isopoda by its appearance when seen from above, recalling the form of the trilobites, the flattened dorsal surface being marked, as in those animals, by two lateral longitudiual depressions. The pleon is consolidated into a single piece and the antenne have only a rudimentary flagellum. It elosely resembles the next species, but is smaller and most readily distinguished by the lateral margin of the thorax, which is, especially in the anterior part, nearly eren instear of zigzag from the projeeting angular segments. The anterior angles of the head are also less produced.

The pleon is shorter and broader, its breadth being to its length as six to tell. The leep transverse groove across the pleon is continued to the margin, with only, at the most, traces of a tuberele at each side. The stylet on the second pair of pleopods of the male (pl. VII, fig. $42 b$, 
$\boldsymbol{s}$, and $s^{\prime}$ ), is a little less elongated than in the next species, not attain. ing the middle of the eilia.

Length $6^{\mathrm{mm}}$; brearth $2.3^{\mathrm{mm}}$. The color is uniform, dull, usually obseured by the athering particles of dirt.

This species was described by Say from Ege Harbor!, New Jersey, where specimens were also collected by Professors Verrill and Smith, in April, 1871, among eel-grass. It has also been found at Savin Rock!, near New Maven, and Noank Marbor!, on piles and among eel-grass; at Vineyarl Sound!; Mass., at Provincetown!, Mass., near Cape Cod in 1879; sparingly near Gloneester! Mass., in 1878, and even as far north as Quahog Bay!, about thirty miles northeast of Portland, Me., where it was taken by the United States Fish Commission, in 1873, along with Venus mereenaria and other southern forms.

Specimens examined.

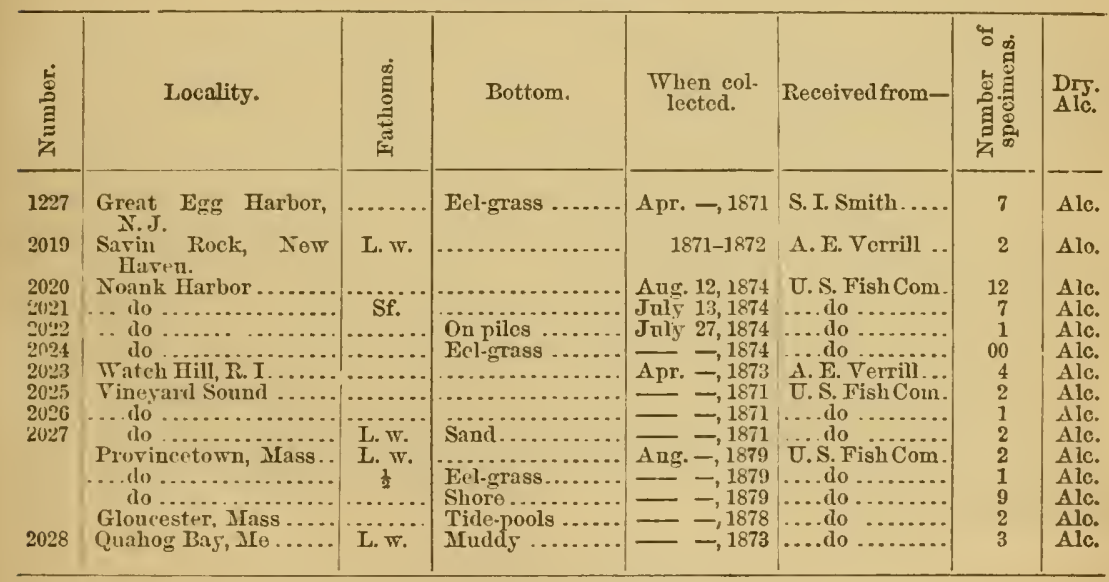

Epelys montosus Harger (Stimpson).

Ilotea montosa Stimpson, Mar. Inv. G. Manan, p. 40, 1853.

Epelys montosus Harger, This Report, part i, p. 571 (277), 1874; Proc. U. S. Nat. Mus., 1879, vol. ii, p. 161, 1879.

Verrill, Am. Jour. Sci., III, vol. vii, p. 45, 1874; Proc. Amer. Assoc., 1873, p. 367, 1874; This Report, part i, p. 370 (76), 1874.

Smith aud Harger, Trans. Conn. Aead., vol, iii, p. 3, 1874.

Whiteaves, Further Deep-sea Dredging, Gulf St. Lawrence, p. 15, "1874."

Plate VIII, Figs. 44-47.

This species closely resembles the preceding, and may be recognized among our Isopoda by the characters mentioned under the former species, from which it is distinguished by the following characters: The eyes are prominent; the anterior angles of the head salient. The tuluereles on the head are more prominent than in the former species. Tho lateral margins of the thoracic segments, especially the second, third, and fourth, are angulated and salient. The pleon is more elongated 
than in the last species, its breadth being to its length as 5.5 to 10 , and the repression erossing it is partially interrnpted at each side by a tubercle which often projeets, as seen from above, just behind the basal lobe, forming a sloulder to the large terminal lobe. The stylet on the second pair of pleopods in the males (pl. VIII, fig. $47, s$ and $s^{\prime}$ ) attains about the mirldle of the eilia.

Length $10^{\mathrm{mm}}$; breadth $4^{\mathrm{mm}}$; color, as in the preceding, dull, and usually mneh obscured by adhering dirt.

A few specimens were collected in Whiting River, near Eastport, Maine, in 1872, which are much more decidedly hirsute than is usual, both on the upper surface and on the legs as well. In other respeets they appear to be referable to this speeies, although the posterior thoracic segments are rather less angulated at the lateral margin. They may be worthy of a variety name hirsutus.

Dr. Stimpson's specimens were "taken in deep water on sandy and muddy bottoms" in the Bay of Fundy, and this species usually replaces the last in the northern localities. It has, however, been taken as far sontl as Block Island Sound!, near the eastern end of Long Island Sound, in 18 fathoms, sandy bottom, and in 29 fathoms Vineyard Sound !. Nortl of Cape Cod it is more eommon. It was dredged in 25 fathoms on St. George's Bank!, at Stellwagen's Bank ! in 20 to 40 fathoms, rocky and sandy bottom; Caseo Bay!, 16 to 17 fathous mud; Bay of Fundy !, at many localities, usually on muddy bottoms, and in 16-18 fathoms mud and stones, off Illalifax!, Nova Scotia, by the Fish Commission, and in 14 fathoms off Richibucto, in the Gulf of Saint Lawrence, by Mr. J. F. Whiteaves. The greatest depth positively recorded is 29 fathoms, but it may very likely have come also from a clepth of 40 fathoms near Stellwagen's Bank.

Specimens examined.

\begin{tabular}{|c|c|c|c|c|c|c|c|}
\hline $\begin{array}{l}\text { 岕 } \\
\text { 兽 } \\
\text { 学 }\end{array}$ & Locality. & 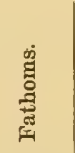 & Bottom. & $\begin{array}{l}\text { When col- } \\
\text { lected. }\end{array}$ & Received from- & 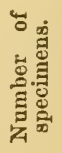 & $\begin{array}{l}\text { Dry. } \\
\text { Alc. }\end{array}$ \\
\hline $\begin{array}{l}2029 \\
2030\end{array}$ & $\begin{array}{l}\text { Vineyard Sound ....... } \\
\text { Block Island Sound . } \\
\text { Off Boston Harbor .... }\end{array}$ & $\begin{array}{l}29 \\
18 \\
16\end{array}$ & $\begin{array}{l}\text { Sand ........... } \\
\text { Speckled sand, }\end{array}$ & $\begin{array}{l}\text { Sept. 14, } 1871 \\
\text { Sept. } 13,1874 \\
1879\end{array}$ & $\begin{array}{l}\text { U. S. Fish Com. } \\
\ldots \text { do } \ldots \ldots \ldots . . \\
\ldots \text { do } \ldots . . . . .\end{array}$ & $\begin{array}{l}8 \\
1 \\
2\end{array}$ & $\begin{array}{l}\text { Alc. } \\
\text { Alc. } \\
\text { Alc. }\end{array}$ \\
\hline & $\begin{array}{l}\text { Gloncester Marbor, } \\
\text { Mass. }\end{array}$ & $7-8 \frac{1}{2}$ & $\begin{array}{l}\text { shells. } \\
\ldots \text { do .............. }\end{array}$ &,- 1878 & do & 30 & Alc. \\
\hline $\begin{array}{l}2032 \\
2031\end{array}$ & George's Bank ........ & $\begin{array}{r}25 \\
20-40\end{array}$ & Rocks and sand. & $=-, 1872$ & A. S. Packard. & 2 & $\begin{array}{l}\text { Alc. } \\
\text { Alc. }\end{array}$ \\
\hline $\begin{array}{l}2033 \\
2035\end{array}$ & 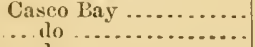 & $\begin{array}{l}16 \\
17\end{array}$ & Mud $\ldots \ldots \ldots \ldots$ & $\begin{array}{l}\text { July } 12,1873 \\
\text { Aug. } 30,1873\end{array}$ & $\begin{array}{l}\text { U.S. Fish Com. } \\
\text { dio }\end{array}$ & $\begin{array}{l}00 \\
00\end{array}$ & Alc. \\
\hline 2038 & $\begin{array}{l}\text { Bay of Fundy, East. } \\
\text { port. }\end{array}$ & & & $\begin{array}{r}\text { Aug. } \\
-\quad, 1873 \\
-\end{array}, 1872$ & $\begin{array}{l}\text { a.do } \\
\text { …do } \\
\text {...do }\end{array}$ & $\begin{array}{r}00 \\
6\end{array}$ & $\begin{array}{l}\text { Alc. } \\
\text { Alc. }\end{array}$ \\
\hline $\begin{array}{l}2039 \\
2040\end{array}$ & $\begin{array}{l}\text { Bay of Fundy, whit: } \\
\text { ing } R \text {. }\end{array}$ & 2 & Mud..... & $\begin{array}{r}-, 1872 \\
-, 1872\end{array}$ & 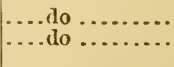 & $\begin{array}{l}2 \\
6\end{array}$ & $\begin{array}{l}\text { Alc. } \\
\text { Alc. }\end{array}$ \\
\hline 2041 & $\begin{array}{l}\text { Seal Cove, Grand } \\
\text { Menan. }\end{array}$ & $8-10$ & &,-- 1872 & ....do . & 10 & Alc. \\
\hline 2042 & Off IIalifax, N.S ...... & 16 & Stones, sand, red &,-- 1877 & ....do . & 4 & Alc. \\
\hline 2043 & .... do & 18 & Mud, fine sand.. & Sept. 15, 1877 & ....do. & 2 & Alo. \\
\hline
\end{tabular}




\section{VI.-ARCTURID A}

Form elongated; antennix large and strong; first four pairs of legs directed forward, ciliated, last three pairs ambulatory; segments of pleon more or less consolidated; uropods operenliform.

This well marked family is as yet represented on our coast by a single species of the genus Astacilla Fleming, Lenchia or Leacia of Johnston and other anthors. The family ean be easily recognized by the four anterior pairs of legs, which are directed forward and strongly ciliated on their inner margins with long slender hairs. The form of the body is elongate and may be very much so, as in our species the length of the body in the male is twenty times as great as its diameter at the middle; in the female eight times. The head is of moderate size and the eyes prominent. The four-jointed antennulie have the basal segment large and swollen. The antenne are large and powerful organs, approaching or even surpassing the body in length, with the first two segments short, the second deeply incised below as in Idotea, the next three segments elongated, and the flagellum varying in the genera, being multiarticulate in Arcturus, and composed of not more than four segments in Astocilla. The mouth parts resemble, in general, those of the Idoteidce. The fourth thoracic segment is more or less elongated. The last three pairs of legs are ambulatory, differing much from the first four pairs. The segments of the pleon are more or less united, and the uropods are modified, as in the preceding family, to form an operculum for the more delicate anterior pleopods. They are wholly inferior, and consist on each side of a large basal segment, straight on the median line, where it meets its fellow of the opposite side, and bearing, in our genus, two small terminal plates at the apex.

This structure of the pleon and its appendages, together with the structure of the antennulæ, antennæ, and the parts of the mouth, point to a close relationship between this family and the Idoteidce. With the Anthurida, however, with which they have often been associated, they seem to have little in common, except, perhaps, the elongate form of body. Even this feature is approached also in the Idoteidce, in Erichsonia, for example.

\section{Astacilla Fleming.}

Leacia (Leachia) Johnston, Ed. Phil. Jour., vol. xiii, p. 219, 1825 (non Lesueur). Astacilla Fleming, Encyc. Brit., fth ed., vol. vii, p. 502.

Johnston, Loud. Mag. Nat. Hist., vol. viii, p. 494, 1835.

Antennal flagellum short, not more than four-jointed; fourth thoracic segment elongated, and, in the females, bearing the incubatory pouch on its inferior surface.

The characters given above seem sufficient to warrant the separation of this genus from Arcturus, notwithstanding the fact that the young of some species, and probably of all, have the fourth thoracic seg. 
ment no longer than the others as noticed by Johnston*, and later by Stebbingt, who draws from the fact an argument against the validity of the genus. I fail to see, howerer, why the argument would not be equally valid against the use, among mammals, of characters drawn from the horns and teeth. Nothing is more common, in case of a genus or family possessing a special development of some organ or set of organs, than to find that the young of such a group resemble the adults of less specialized groups. If, however, as may be possible, a gradation can be established between forms which, like Arcturus Baffini, have the fourth thoracie segment large but only slightly elongated, and forms like Astacilla longicornis or A. granulata, in which this segment is much elongated, equaling or surpassing the other six in length, there would then be, perhaps, no sufficient reason for retaining both genera. For the present it seems desirable to keep them separate, and to the characters given above we may add the following:

The head is produced at the sides around the bases of the antennulie, and is united dorsally with the first thoracie segment, the sutures being evident only at the sides where the segment is produced around the hinder part of the head. The flagellum of the antennx consists of three, or sometimes only two, distinet segments and a terminal spine, which is perhaps to be regarded as a third or fourth segment. The maxillipeds (pl. IX, fig. 52 a) are robust and operculiform, with a thick external lamella and a five-jointed palpus, but little flattened. The mandibles are destitute of palpi.

The first three thoracic segments are subequal and short; the fourth much elongated in both sexes; in the males it is slender and eylindrical; in the females it is more robust, and bears on its inferior surface the incubatory pouch. This pouch is thus confined to a single segment, and is composed of a pair of elongated lamella, attached along their onter margins, and overlapping widely along the ventral surface. It occupies nearly the entire inferior surface of the segment. The last three thoracic segments are short and subequal, and the articulation at the posterior end of the fourth segment is eapable of ensiderable motion, and, in our species, is usually flexed backward nearly at a right angle. The first pair of legs (pl. VIII, fig. $49 b$ ) have the basis directed backward and the remaining segments eiliated and turned forward, and is more robust than the three succeeding pairs, which are slender, of nearly equal size, and consist of only five segments, which are turned forward from the basis and held beneath the head. They are strongly ciliated, especially on the last three segments. One of the fourth pair of legs is shown on plate VIII, figure 50. The last three pairs of legs are of entirely different structure, being robust and prehensile with strong short dactyli.

The pleon is consolidated into a single segment, which, however, shows traces of its composite nature. It is vaulted above and excavated on

* Loud. Mag. Nat. Hist., vol. ix, p. 81, fig. 15, 1836.

† Ann. Mag. Nat. Hist., IV, vol. xv, p. 187, 1875., 
its inferior surface for the delicate pleopods, which are protected by the opereuliform uropods. Both rami of the uropods are present in our species, but the outer is much the larger and conceals the delicate inner ramus in an exterior view. The onter ramus only is thickened and of functional importance as an operenlum.

The habits of these animals are deseribed by Goodsir in the Edinburgh New I'hilosophical Jommal, vol. xxxi, p. 311. He says, "With the dredge I have procured specimens ** * * alire, and hare liept them in glass jars of sea-water with sand and eorallines, and have thus been enabled to watch their habits closely.

"Under the circumstances just stated, each individual nill select a branch of coralline, will keep that branch exelusively to itself, and will defend it with the greatest vigor against all intruders. It fixes itselt to its resting-place by means of its true thoracie feet, and seldom uses theso for progression. When it falls to the bottom of the ressel, it fixes its long pointed antennx firmly into the sand, and, with the assistance of the true feet, drags and pushes itself forward. This, howerer, may not be a natural mode of progression, but may be adopted in eonsequence of the artificial circumstances in which the animal is placed.

"Swimming is the natnral mode of progression. It is amusing to see one of these animals resting, in an erect posture, on a branch of coralline, by means of its true thoracic feet, waving its boty backwards and forwards, throwing abont its long inferior antennx, and ever and anon drawing them through its anterior fringed feet, for the purjose of cleaning them. It frequently darts from its branch, with the rapiclity of lightning, to seize with its long antennce some minute crustaceous animal, and returns to its resting-place to devour its pres at pleasure.

"In this manner the antenne are the only organs employed in seizing and enclosing the pres, which they drag to the anterior thoracic feet, which hold it while it is being devourerl."

I have discarded Johnston's name Leachin, or according to his orthography Leacia, proposed in 15:5, as being preocenpied by Lesueur * in the Mollusea in 1821. Astacilla is used by Fleming in the 7 the edition of the Encyclopredia Britamica; 1S12 is giren as the date in the copf of the seventh rolume of the Encyclopadia that I have seen, but Johnston refers to Fleming in 1835 as authority for the name, quoting the Encyclo. pedia. Fleming says in the Eneycloperlia (rol. vii, p. 502): "The genus was instituted by the Rev. Charles Cordiner of Banff in 17St for the reception of a British species which has been denominated Astacilla longicornis." I have not been able to find whether Cordiner published the name at that early date or whether it was a manuscript name only. If actually published in $178 \pm$ it wonld have many years' priority orer Arcturus, and the author who would unite the genera should use the name Astacilla. Even if not published until 1835 it appears to have the best claim to recognition as the generic name of the type here treated of.

* Jour. Acad. Nat. Sci. Phila., vol. ii, p. 89, 1821. 
Astacilla granulata Harger (G. O. Sars).

Leachia granulala G. O. Sars, Arch. Math. Nat., B. ii, p. 351 [251], $187 \%$. Astacilla Americana Harger, Am. Jour. Sci., III, vol. xv, p. 374, 1878.

Astacilla granulata Harger, Proe. U. S. Nat. Mus., 18ז9, vol. ii, p, 161, 1879

Plates VIII AND IX, Figs. 48-5:.

The elongated fourth thoraeic segment distinguishes this species at once from all the other Isopoda of our coast.

The body is in the female eight times and in the male about twenty times as long as broad, the breadth being measured across the fourth thoraeic segment. It is roughened and tubereulated throughout. The head is produeed at the sides in front beyond the middle of the basal segment of the antenunle, and is tubereulated above and erossed by two transverse grooves, the first between, and the second behind the eyes, while a thind similar groove evidently marks the place of the suture be. tween the head and the first thoracic segment. The eyes are lateral, prominent, round-ovate, broadest in front. The antenumle in the female slightly surpass the second segment of the antenur, in the male they nearly attain the middle of the third segment, the flagellar seginent being elongated in the male, longer than the three pedunenlar segments together (pl. VIII, fig. 48 a). The seeond and third segments of the antennulie are in both sexes short aud slender. The antennæe are fully three-fourths as long as the body ; the first segment is shorter than that of the antemunla, being surpassed at the sides by the lateral proeesses of the head and thus concealed in a lateral view; the seeond segment is large, searcely longer than broad, and presents below a deep angular sinus in the distal margin, as in Inlotea; third segment abont as long as the head; fourth segment longest, slightly exeeeding the fifth, which is equal to the first three taken together. The flagellum* (pl. VIII, fig. $49 a$ ) is less than half the length of the last peduneular segment and usually consists of three distinet segments, of which the first is as long as the other two; the seeond is equal in leugth to the third, which is tipped with a terminal spine or claw, probably to be regarded as a fourth segment. Sometimes, however, only two distinet segments exist in the flagellum besicles the claw. The flagellar segments are finely and sharply dentienlate along the margin whieh is inferior when the antemne are straightened. The charaeter of this dentienlation is shown in figure $49 a^{\prime}$ on plate VIII, where a small seetion of the margin is shown enlarged 100 diameters. The maxillipeds (1)l. IX, fig. $52 a$ ) are robust and cover the other parts of the mouth; the external lamella $(l)$ is ovate and in the figure is somewhat bent outward from its natural position. The palpus of the maxillipeds is five-jointed and but little flattened, strongly ciliated along the inner margin. The terminal lobe

* The figure of the animal (pl. VIII, fig. 48,) was sent to the engraver before I had seen any specimens except the imperfect ones collected in 1877 , and the flagellum of the antenna was dotted from the young specimens. Fig. $49 a$ on plate VIII was made from a specimen obtained in 1878 . 
(pl. IX, fig. $52 a, m^{\prime}$ ) is quadrate, searcely ciliated at the apex, and distinctly articulated with the maxilliped. The outer maxillw (pl. IX, fig. 52 b) are three-lobed and strongly ciliated. The inner maxillio (pl. IX, fig. $52 c$ ) are two-lobed, the lobes robust and short, the outer armed with short spines at the apex, the inner with three slender curved setre.

The thoracic segments are coarsely grinulated or tuberculated; the first is produced at the sides around the head nearly to the eyes; the others have their anterior and posterior margins transverse. The fourth segment in the female is a little less than three times as long as broad, and is longer than the other six segments taken together, but is onl. four-fifths as long as the last three segments together with the pleou. It is tuberculated, especially abore, but bears no prominent tubercles or spines, and is subcylindrical. In the male this segment (pl. VIII, fig. 48 b) is more elongate and much more slender, exceeding in length the three following segments with the pleon. In the ordinary position the thorax is geniculate at the posterior articulation of the fourth segment, forming nearly a right angle with the rest of the body. The last three segments have their epimeral regions angulated and salient. The first pair of legs (pl. VIII, fig. $49 \mathrm{~b}$ ) are of moderate length and, beyond the basal segment, flattened; the basal segment is directed backward but the leg is bent upon itself at the ischium and the remaining segments are directed forward and applied to the under surface of the head. The ischium and merus support but few cilia, and these mostly along their inner margins, but the carpus, propodus, and dactylus are not only ciliated on the inner margin with slender simple cilia, but also bear on the side toward the body stout scattered spinulose setre, which are specially abundant on the propodus. The opposite side of the leg is nearly smooth. The second, third, and fourth pairs of legs are five-jointed and similar to each other, except that the basal segments of the second and third are somewhat shorter than in the fourth (pl. VIII, fig. 50). The second pair is shorter than the third, and the fourth is a little the longest. All these legs are directed strongly forward and habitually held nearly in the position shown in the figure, under the anterior surface of the body and the head. The last three segments are furnished with elongated setæ along their inner margins. These setæ are inserted in two lows and so placed as to diverge at an open angle. The dactyli appear to be obsolete in these legs. The fifth, sixth, and seventh pairs of legs are of quite a different and more ordinary structure. They contain the full number of segments, and are terminated by robust, slightly curved dactyli. A young specimen obtained has only two pairs of legs of the ordinary form, the last or serenth pair being represented only by rounded tubereles, one on each side of the serenth segment.

The pleon is elongate-ovate, narrower in the male (pl. VIII, fig. $48 \mathrm{c}$ ). Dorsally it is strongly convex, especially in front. It is two-thirds as long as the fourth thoracic segment in the female, and three-fifths as 
long as that segment in the male. It is provided with rather coarse tubercles in front, which are arranged transversely in three rows, and behind the third row is a deep transverse groove, behind which the tubercles are less prominent and more of the character of granulations. On each side before the middle is a prominent, sub-acute tooth, directed outward and backward immediately above the articulation of the nropods. The tip of the pleon is not spiniform, but only slightly attenuated and obtuse. The pleopods are delicate in structure, and the anterior pairs are ciliated. The uropods or opercula are more than nine-tenths as long as the under surface of the pleon (pl. VIII, fig. $48 \mathrm{c}$ ), but cannot be seen from above. They consist on each side (pl. VIII, fig. 51) of an elongated, semi-oval, basal, lamellar segment, thickened and vaulted externally, with the anterior end rounded, and bearing a salient semi-circular process on the onter margin near the anterior end, for articnlation with the pleon. Posteriorly this plate is tapering and it is broadly truncated at the tip, where it bears two lamelliform rami. Of these the external is thick, like the basal segment, and is of an elongate triangular form and completes the operculum behind, while the inner ramus is a small and delicate oval plate, articulated to the basal segment near its inner distal angle, and completely covered and concealed by the outer ramus when the operenlum is closed. The inner ramns is sparingly ciliated at the tip. The pleopods are very delicate, and the anterior pairs are ciliated

In the females the lamella forming the incubatory ponch are thickened and tuberculated or granulated along the onter edge where they are attached to the segment. The thickened area is bounded by a longitudinal ridge, beyond which the lamella is thin, smooth, and translucent, permitting the eggs to be seen through it, and the thin portion of the right lamella (in the specimen examined) overlaps its fellow of the opposite side so far as to bring its edge along the base of the ridge bounding the thickened portion of the opposite lamella. Near the anterior end and on the outer side is a rounderd lobe in the margin of the lamella for articulation with the segment.

Length of female $10^{\mathrm{mm}}$; male $11^{\mathrm{mm}}$; diameter of fourth thoracic seg. meut, female $1.2^{\mathrm{mm}}$; male $0.5^{\mathrm{2mm}}$; color in alcohol, nearly white.

This species was described by the writer withont having seen Sars' description of Leaehia gramulata. The volume containing his description has since bcen obtained by the Yale College Library, and a careful comparison of our specimens with his description leaves little doubt that the species is identical with his. His specimens were somewhat larger than our's, females measuring $14^{\mathrm{mm}}$ and males $17^{\mathrm{mm}}$. The females in A. longicomis Sowerby are much larger than the males, and the reverse relation of size in this species appears to be unusunl in the genus.

Specimens were first collected on this coast on George's Bank!, in the summer of $187 \%$, and the three then obtained wre found adhering to Primnoa, and had been dried and somewhat broken. Better specimens were collected adhering to the cable of the schooner 'Marion,' at Ban- 
quereau!, by Capt. J. W. Collins, August 25, 1878, and a fine specimen was obtained in seven fathoms off Miquelon Island!, south of Newfoundland, by Capt. C. D. Murphy and erew of the schooner 'Alice M. Williams,' July 3, 1879. Sars' specimens were collected between Norway and Iceland at stations 18 and 48 , of which the respective localities as given by lim are latitude $622^{\circ} 44.5^{\prime}$ north, longitude $1048^{\prime}$ east, in 412 fathoms, clayey bottom, and latitude $64^{\circ} 36^{\prime}$ north, longitude $10^{\circ} 21.5^{\prime}$ west, in 299 fathoms, clay and sand.

Specimens examined.

\begin{tabular}{|c|c|c|c|c|c|c|c|c|}
\hline \multirow{2}{*}{ 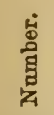 } & \multirow{2}{*}{ Locality. } & \multirow{2}{*}{ 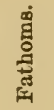 } & \multirow{2}{*}{ Bottom. } & \multirow{2}{*}{$\begin{array}{l}\text { When col- } \\
\text { lected. }\end{array}$} & \multirow{2}{*}{ Recoived from- } & \multicolumn{2}{|c|}{ Specimens. } & \multirow{2}{*}{$\begin{array}{l}\text { Dry. } \\
\text { Alo. }\end{array}$} \\
\hline & & & & & & No. & Sex. & \\
\hline \multirow{3}{*}{$\begin{array}{l}2045 \\
2046\end{array}$} & George's Bank.... & & &,-- 1877 & U.S. Fish Com. & 2 & † $\mathrm{y}$ & Alc. \\
\hline & Banquereau, N. S. & 250 & Rocky ..... & 二-, 1877 & Capt.J. W. Col- & $\begin{array}{l}1 \\
3\end{array}$ & 8 & $\begin{array}{l}\text { Alo. } \\
\text { Alo. }\end{array}$ \\
\hline & Off Miquelon Island. & 7 & & July 3, 1879 & $\begin{array}{l}\text { Capt.C.D.Mur. } \\
\text { phy and crew. }\end{array}$ & 1 & q & Alo. \\
\hline
\end{tabular}

\section{VII.—SPHAROMID无.}

Body short and convex; head transverse; antennulæ and antennæ multiarticulate, with evident distinction into peduncle and flagellum; mandibles palpigerous; epimera united with the thoracic segments; anterior segments of the pleon short, uniterl and articulated with the large terminal segment; uropods lateral with only one movable ramus.

This family is sparingly represented on the eastern coast of the United States, and within our limits only a single species is found, belonging to the typical genus Spharoma. The animals are usually of small size, and have the body short, broad, and convex. The head is transverse, and both pairs of antenuæ are inserted near together below its anterior margin. These organs are much better developed than in the following family. The epimera are faintly indicated in the thoracic segments by impressed lines. The anterior segment of the pleon is similarly marked with transverse sutures indicating the segments of which it is composed. The last segment is large, and one or more of the posterior segments may be notched, tuberculated, sping, or variously modified, as occurs in many foreign genera. Below, the pleon is much excavated for the pleopods, which, as usual, are in five pairs, the anterior three ciliated. In the males a slender stylet is articulated near the base of the inner lamella of the second pair, and lies along its inner side, so that in the natural position they lie close together on opposite sides of the middle line of the body. These pleopods, though receired into a carity in the under surface of the pleon, are not protected by any operculum nor opercular plates, as in most of the preceding families, nor is the external pair thickened, as in the Anthurida. 
Sphæroma Latreille.

Spharoma Latreille, Hist. nat. des Crust. et des Ins., tome vii, p. 11, 1804.

Body contractile into a sphere; antennulæ and antennæ short or of moderate length; maxillipeds with a five-jointed palpus; legs all ambulatory; dactyli short and thick; uropods short, ramus and basal segment subequal.

The name of this genus is derived from the peeuliar habit of many of the species of rolling themselves into a ball when alarmed. The bods is so constructed as to facilitate this operation, the antennulæe and antennæ being receired into a groove at the side of the head; the epimeral regions of the thoracie segments behind the first are narrowed nearly to a point and project well downward so as to meet very elose together and still leave room for the included legs, while the uropods, shutting together like a pair of seissors, fold also partly under the large terminal segment of the pleon and fill the crevice between the pleon and the head. The maxillipeds in this genus are provided with a long densely eiliated five-jointed palpus. The maxillæ are mueh as in the Idoteida, the outer pair three-lobed and strongly ciliated, the inner two-lobed with the immer lobe small and tipped with pectinate setre, the outer larger and armed with eurved denticulated spines. The mandibles have a strong molar process, a dentigerous lamella armed with acute teeth, and a three-jointed palpus.

The legs are rather weak and nearly alike throughout, all ambulatory. The pleon is suarcely narrower than the segments of the thorax and appears to consist of two* segments orily, of which the first is much like the last thoracic segment, but more strongly produced at the sides than is that segment and marked with impressed lines. It is articulated with considerable motion to the large scutiform terminal segment, which, in this genus, is rounded and entire at the tip, and not strongly tuberculated nor spiny. Anteriorly, the angles of this segment are produced downward into a rounded lobe in front of the shoulder from which arise the uropods. These organs are not greatly elongated; the basal segment is produced into a plate about equal in size to the single ramus.

\section{Sphæroma quadridentatum Say.}

Spharoma quadridentata Say, Jour. Acad. Nat. Sci. Phil., vol. i, p. 400, 1818.

Dekay, Zool. New York, Crust., p. 44, 1844.

White, List Crust. Brit. Mus., p. 102, 1847.

Harger, Am. Jour. Sci., III, v., p. 314, 1873; This Report, part i, p. 569

(275), pl. v., fig. 21, 1874; Proc. U. S. Nat. Museum, 1879, vol.ii, p. 161, 1879.

Verrill, This Report, part i, p. 315 (21), 1874.

Plate IX, Fig. 53.

The outline of the body when extended is a pretty regular ellipse, but the animal, when disturbed, rolls itself into a ball with facility, and by

* The pleon is inadvertently described by Bate and Westwood in the British SessileFrad Cmictacen vol ii $n 401$ a " having all the seoments fused torether." 
this habit may be distinguished from the other marine Isopods of our coast.

The head is rounded in front with an elerated margin, and a slight median projection between the bases of the antennula. The eyes are small and sub-triangular, widely separated. The antennnla and the antenna are inserted on the inferior surface of the head, and, when the animal contracts, they are received into a groove along the margin of the head and anterior thoracic segment. The antenmulæ (pl. IX, fig. 54a) have the basal segment large, the second segment small and conical, the third slender, cylindrical; the flagellum about ten-jointed, ciliated, shorter than the peduncle. In the antemma (pl. IX, fig. $54 b)$ the peduncular segments decrease but little in diameter, and increase in length from the first to the fifth, and are followed by a flagellum about as long as the peduncle, tapering from the base, with the basal segments strongly ciliated along their inner or anterior distal margins. The antennæ are separated at the base by a triangular, somewhat projecting epistome, which also partly separates the bases of the antennula. The maxillipeds have the basal segment short and somewhat triangular, with plumose setre at the acute apex, and a five-jointed palpus, of which the first segment is short and smooth, and the following segments strongly ciliated along more or less of their inner margins. The onter maxillie are terminated by three orate rather acute lobes, which are strongly eiliated. The inner maxillæ have the inner lobe tipped with four pectinated curred setre, and the outer armed with strong denticulated spines. The mandibles are robust and bear on their external surface at the apex a dentigerous lamella, or usually two such on the right mandible, receiving the lamella of the left between them; below the lamella is a strongly ciliated ridge supporting the dentigerous lamella and connecting it with the molar process, which is large and strong. The mandibular palpi are slender, with the last segment sub-semieireular, bearing at its apex a few serrated spines, and below a comb of straight setæ; the middle segment bears a similar comb with stouter spiny setre at the ends.

The first thoracic segment is longer than the others, and much elongated at the sides, embracing the head as far as its anterior margin. Abore this lateral expansion on each side the segment is excavated for a projecting lobe of the head behind the eye. The second, third, and fourth segments are somewhat shorter than the first and longer than the fifth, sixth, and serenth. The margin of the last segment bends slightly backward at the middle. In the thoracic segments behind the first the epimeral sutures are indicated by a faint depressed line, below which the lateral margin of the second segment tapers to an obtusely rounded point, the third is more aentely pointed, the fourth oblique and acute behind, the fifth and sixth also oblique but less aente, and the serenth rounded. The legs are weak, hairs, and much alike throughout, formed for walking, and none of them chelate. The daetylus in all is short and robust, armed with a stout curved spine or claw at the tip, and a smaller 
straight spine below it. In the first pair of legs the earpus is short and triangular, the ischium and merus bear on their upper margin a row of long slender plumose hairs. In the seeond and third pairs of legs these hairs are also found, and the carpus is longer. The fourth pair of legs are robust, the following pairs more slender to the seventh. All are well provided with slender hairs, with a few stouter ones intermixed.

The anterior segments of the pleon are consolidated into a single piece somewhat resembling the last thoracic segment, but marked at the sides by depressed lines, indicating sutures, as shown in pl. IX, fig. 53. At the sides this segment is broadly rounded and projects much below the seventh thoracic when the animal is contracted. The large terminal segment has a similar lobe in front of the bases of the uroporls. At the insertion of the uropods the segment is considerably contracted laterally, but is rounded and strongly margined behind. Its anterior lobe, all the thoracic segments, and the head are also margined by an eleration running completely around the animal except where it is interrupted by the uropods. The uropods extend nearly to the tip of the telson, and consist on each side of a basal segment continued backward into a narrow oval plate with entire margins, flattened below, where a similarlyshaped ramus is articulated near its base, the two shutting together like the blades of a pair of scissors. The articulated plate bears four more or less acute serrations on its exterior margin, whence the specific name. The pleopods are eiliated, and the second pair (pl. IX, fig. $54 c$ ) bears, in the male, on the inner lamella, a slender curved stylet, longer than the lamella, and articulated near its base.

Length about $S^{\mathrm{mm}}$, breadth $4^{\mathrm{mm}}$. The color, as usual in shore species, is variable; some are of a mniform slaty gray, many are marked on the dorsal surface with a whitish, cream color, or rosaceous pateh, bordered more or less with dark or black. This pateh has commonly a longitudinal direction, and is usually symmetrieal, and may be broat or much narrowed in the middle. On the dark or barnacle-covered rocks, where these animals are often found, the colors are evidently protective, but they are imperfectly preserved in alcohol.

This species was described by Say, who "found these animals rery numerous on the beach of Saint Catherine's Island, Georgia, concealing themselves under the raised bark, and in the deserted holes of the Tercdo, \&c., of such dead trees as are periodically immersed." He also gives East Florida as a locality, and there are specimens in the Yale Museum from Florida! It extends as far north as Provincetown, Mass.! near the extremity of Cape Cod. It is common on the southern shore of New England!, and is usually found among algæ or rocks. 
Specimens examined.

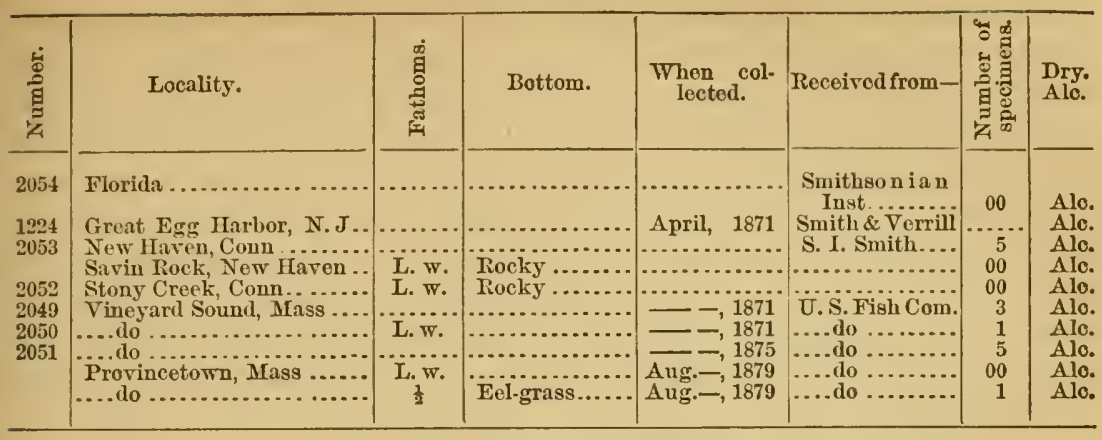

\section{VIII.-LIMNORIID $\nexists$.}

Body compressed; antennulæe and antennæ short, subequal ; mandibles palpigerous, formed for gnawing; feet not prehensile, all similar, with short, robust dactyli; epimera united with the thoracic segments; pleon of six distinct segments; pleopods similar in form throughout; uropods lateral, biramous.

This family as constituted above contains the single genus Limnoria Leach, which appears also to contain but few, or perhaps a single, species* of wide distribution. This genus was placed in the tribe Asellotes homopodes with the Asellide by Edwards, without, however, having examined the animals himself. He has been generally followed in this arrangement by later anthors. Previous authors had associated the geuns, as it appears to me more justly, with Sphceroma and the Cymothoide in the wide signification of the latter term. White, in his List of British Crustacea, used the name Limnoriade to include this genus with the Asellide. I have preferred to constitnte a new family for the genus, which has, however, evident relations with the Sphceromida, and perhaps should set be united with that family.

Under the circumstances family characters can scarcely be separated with certainty from those of generic or even of specific value only, but for the purpose of comparison with other families certain important characters may be here stated. The body is somewhat depressed dorsally, but is also compressed at the sides, and when extended is subvermiform. It is nearly capable of being rolled into a ball, as in the genus Sphoroma. The head is of moderate size and strongly rounded above, as in Sphoroma, and the eyes are widely separated and on the sides of the head, a condition not usual in the Asellides. The antennule are short and stout and the basal segment is but little larger than the second; the flagellum

\footnotetext{
* It is perhaps hardly necessary to remark that $L$. xylophaga Hesse, Ann. Sci. nat., tome x, p. 101, pl. ix, 1868, is not an Isopod. According to Prof. Smith it is Chelura terebrans Phillipi, a boring amphipod often found associated with Limnoria. See an article by that author in the Proceedings of the U. S. National Museum, 1879, vol.ii, pp. 232-235.
} 
consists of a single, almost rudimentary segment. The antennæ differ widely from any in the Asellida, since they are less robust than the antennulæ, and but little longer; the peduncular segments are all short, having almost the same proportion to each other as in Sphceroma (see pl. IX, figs. $54 b$ and $56 b$ ), the last two being together about equal in length to the first three, instead of far surpassing them as in the Asellidce; the flagellum is short and few-jointed, mostly made up of a tapering basal segment, and not at all resembling the slender multiarticnlate flagellum of the Asellida. The mandibles are adaptively modified in accordance with the boring habits of the speeies, but the other mouth parts do not seem to present characters from which eomparisons need be drawn with other families.

The legs are somewhat similar to those seen in many Asellide, being furnished with short dactyli, each armed with a strong eurved elaw, and a shorter spine below. A similar form of leg is, however, seen in Sphceroma. The epimera are united to the lateral margins of the thoracic segments almost precisely as in Sphcroma, an arrangement that does not prevail in the Asellider.

The pleon has all its six segments well developed and perfectly separated from each other, while in the Asellida they are united into a single seuti. form segment, or at most, the basal segment only is more or less distinct. The pleopods are of the normal number and similar in form and texture thronghout; the anterior pairs are ciliated. Each pair of pleopods consists of a basal segment, bearing an inner narrow lamella and an outer oval one, which, except in the fifth pair, are well ciliated. In the male the inner lamella of the second pair bears, on its inner margin, a stylet, as in Spharoma and many other genera of Isoporla. In the Asellide the branchial pleopods are in fewer than five pairs, and are protected in front by a simple or compound opereulum of firmer texture than the other pleopods. Dr. Coldstream* fell into an error in describing the respiratory organs as consisting of "six pairs of seale-like bodies, pendant from the anterior segments of the tail, * * arranged in three rows, in an imbricated manner, one of each kind ('oval' and 'nearly quadrangular') being articulated together on a common peduncle on either side." He further deseribes, loc. cit., 1. 324, "two vesicular borlies of an oval form" behind the branchix. These organs were without doubt the external lamellæ of the fifth pair of pleopods, as shown by his figure. There are, however, four instead of three ciliated pairs anterior to the last pair, one of which was overlooked by Dr. Coldstream, and in this error he has been followed by Bate and Westwood. $t$ If the observations of Dr. Coldstream had been correet, an affinity might have been indicated with the A sellidoc. The terminal segment is flattened and sentiform, in shape resembling that of Jora, but the uropods are strictly lateral, being attached at the broadest part of the segment and in front of the middle. 
The relations of the present family with the Sphcromidcc appear to be more elose, but the strueture of the mandibles and perhaps also that of the maxillipeds, the fully segmented pleon and the biramons uropods seem to be characters of family value, which, however, a fuller investigation of the boriug Sphceromidce might go far to break down.

\section{Limnoria Leach.}

Limnoria Leach, Ediuburgh Encyc., vol. vii, p. "433" (Am. ed., p. 273), "1813-14."

Mandibles with a nearly even chisel-like enttiug-edge at the tip and no molar process; maxillipeds elongate, with a well-developed external lamella and a five-jointed palpus; first thoracie segment large; uropods with the outer ramus very short and almost obsolete.

The above characters differ from those by which Leach separated this genus from Cymothoa and the Sphceromide, with which he associated it.

IImuoria lignorum White (Rathke).

"Cymothoa lignorum Rathke, Skrivt. af Naturh. Selsk., v. 101, t. 3, f. 14, 1799" (IVhite).

Limnoria terebrans Leach, Ed. Encyc., vol. vii, 1. '433' (Am. ed., p. 273), "1813-14"; Trans. Linn. Soc., vol. xi, p. 371, 1815; Dict. Sci. nat., tome xii, p. $353,1818$.

Samouelle, Ent. Comp., p. 109, 1819.

Desmarest, Consiu. Crust., 1). 312, 1825.

Latreille, Règne Anim., tome iv, p. 135, 1829.

Coldstream, Eđinb. New Phil. Jour., vol. xvi, pp. 316-334, pl. vi, 1834.

"Hope, Trans. Ent. Soc. Lond., vol. i, p. 119 " (B. \& W.).

Thompson, Edinb. New Phil. Jonr, vol. xviii, p. 127, 1835; Ann. Mag. Nat. Hist., vol. $\mathrm{xx}$, p. 157, 184 .

Templeton, Lond. Mag. Nat. Hist., vol. ix, p. 12, 1836.

Moore, Charlesworth's Mag. Nat. Hist., n. s., vol. ii, p. 206, 1838; ibid., vol. iii, pp. 196, 293, 1839 .

Edwarls, Annot ile Lamarck, tom. v, p. 276, 18:33; Hist. nat. des Crust., tom. iii, y. 145, 1840; Riegne Anim. Crust., p. 197, pl. 67, f. 5, 1849.

Gould, Invert. Mass., 1p. 338, 354, fignue, 1840.

Fleming, Encyc. Brit., 7 ed., vol. vii, 1. 50:, 1842.

Dekay, Zool. New York, Crust., p. 48, pl. ix, fig. 33, 1844.

"Kirby and Spence, Int. Entom., 5th ed., p. 233 ; 6th ed., p. 203" (White.)

White, List Crust. Brit. Mus., p. 96, 1r47 ; lirit. Crust. B. Mus., p. 68, 1850.

Dalyell, Powers of the Creator, rol. i, p. :41, pl. 1xv, figs. 7-15, 1851.

Leidy, Jour. Acad. Nat. Sci. Phil., II, vol. iii, 1). 150, 1855.

Gosse, Man. Mar. Zool., vol. i, 1. 136, fig. 242, 1855.

Steenstrup and Liitken, Vidensk. Meddel., II, vol. ii, p. 275, 1861.

Hesse, Ann. Sci. nat., Zool., V, tome x, p. 113, 1868.

Jones, Trans. Nova Scotian Inst. Nat. Sci., vol. ii, pt. iv, p. 99, 1870.

Verrill, Proc. Am. Assoc., 1873, p. 367, 1874.

Macdonald, Trans. Linn. Soc., II, Zool., rol. i, p. 67, 1875.

Andrews, Q. Jour. Mic. Sci., II, vol. xv, p. 332, 1875.

Limnoria lignorum White, Pop. Hist. Brit. Crust., p. 227, pl. 12, fig. 5, 1857.

Bate, Rep. Brit. Assoc., 1860, p. 225, 1861.

Bate and Westwood, Brit. Sess. Crust., vol. ii, p. 351, figure, 1868. 


\section{REPORT OF COMMISSIONER OF FISH AND FISHERIES.}

\section{Limnoria lignorum-Continued.}

Norman, Rep. Brit. Assoc., 1868, p. 288, 1869.

Möbins, Wirbellos. Thiere der Ostsee, p. 122, 1873.

Parfitt, Fauna of Devon, Sess. Crust., p. (19), 1873.

Verrill, Am. Jour. Sci., III, vol. vii, pp. 133, 135, 1874 ; Proc. Am. Assoc., 1873, p. 371, 1874 ; This Report, part i, p. 379 (85), 1874.

Harger, This Report, part i, p. 571 (27\%), pl. vi, fig. 25, 1874; Proc. U. S.

Nat. Mns., 1879, vol. ii, p. 161, 1879.

M'Intosh, Ann. Mag. Nat. Hist., IV, vol. xiv, p. 273, 1874.

Stebbing, Trans. Devon. Assoe., 1874, p. (8), 1874. Ann. Mag. Nat. Hist., IV, vol. xvii, p. 79, 1876.

Whiteaves, Further Decp)-Sea Dredging, Gulf St. Lawrenee, p. 15, “1874." Metzger, Nordseefahrt der Pomm., p. 285, 1875.

Meinert, Crust. Isop. Amph. Dec. Daniæ, p. 77, $187 \%$.

Smith, Proe. U. S. Nat. Mus., 1879, vol. ii, p. 232, fig. 2, 1880.

Limnoria uncinata Heller, Verh. k. k. Zool. bot. Ges. Wien, B. xvi, p. 734, 1866. Stalio, Cat. Crost. Adriatic, p. 211, $187 \%$.

Plate IX, Figs. 55-57.

This species may in general be recognized by its habits, being usually found burrowing in submerged timber, to which, notwithstanding its insignificant appearance, it often proves very destructive.

The body is subeylindrical, tapering slightly at each end and covered above with short hairs to which more or less dirt usually adheres. The head is narrower than the first thoracic segment. The eyes are lateral and consist of about eight ocelli, one central and the others around it. The antennulæ (pl. IX, fig. $56 a$ ) are short and seem to arise from near the middle of the front of the head. The basal segment is the largest; the second and third are of slightly decreasing size; the fourth or flagellar segment is. much the smallest, and tipped with setre. The antennæ (pl. IX, fig. $56 b$ ) are more slender than the antennulæ, and arise just below their bases and a little farther apart. The first two segments are short; the third slightly longer; the fourth and fifth increasing somewhat in length; the flagellum is not longer than the last two peduncular segments, and consists of a tapering segment, followed by a few short terminal segments provided with a terminal brush of setr. The maxillipeds (pl. IX, fig. $56 c$ ) are slender; the external lamella is semi-ovate, with the inner margin nearly straight, acute, and ciliated at the tip ; the palpus is five-jointed but short, with the segments flattened, and all but the first ciliated along their inner margins. The onter maxillæ (pl. IX, fig. $56 d$ ) are slender, three-lobed, and ciliated at the tip. The imner maxillæ (pl. IX, fig. $56 e$ ) are also slender, the inner lobe tipped with pectinate bristles, the outer with robust spines. The mandibles (pl. IX, ifg. $56 \mathrm{f}$ ) are somewhat elongate, but of a simple form, being curved inward, flattened and chisel-shaper at the tip; below there is a slight tubercle, apparently the rudiment of the molar process; extemally, above the origin of the palpus, is a prominent tubercle; the palpus is short, of three subequal segments, the last furnished with a rather imperfect comb of setx.

The first thoracie segment is about twice as long as any that follow; it is erossed by a broad, slallow depression, and is rounded at the sides. 
The second and third segments are each about half the length of the first. The epimeral sutures are evident, and the epinera are rounded behind in the second segment, but a little more prominent in the third, becoming acute and increasing in size and extension backward to the seventh. The fourth segment is slightly shorter than the third, and per. haps a little broader; the last three are short, decreasing in length to the serenth, but maintaining about equal wilth. The legs are short and rather robust. The first pair have the carpus triangular, but this seg. ment becomes more elongate in the sneeeding pairs. The dactyli are robust, and are armed with a strong emred spine or claw at the tip and a smaller one below it. The merus, and usually the isehimm and earpus, bear a few spiniform tubercles on the lower surface except in the last pair, which are also more elongated and slender than the others.

The pleon is seareely narrower than the thorax, and tapers but little; the first four segments are of equal length; the fifth is longer with a median eleration and a transverse depression on each side. The last segment (pl. IX, fig. $5 \bar{i} a$ ) is transversely oval or subeireular, broader than long, with the anterior margin raised, especially at the middle, where the elevation is continued a short distance on the segment, but posteriorly it is flattened. The posterior margin is eiliate with hairs of varions lengths. The uropods (pl. IX, fig. 57b) are attached just in front of the midclle of the segment at its widest part. They consist on each side of a somewhat werlge-shaped basal segment, eiliated and bluntly denticulated distally on the outer side, and supporting two rami, between which it is produced below into a strong tooth-like process. The onter ramus is very short and enrved ontward; the inner is not as long as the basal segment, and is ciliated externally and at the tip. Underneath, the pleon is much excarated for the pleopods, which are strongly eiliated. The first pair (pl. IX, fig. 57c) eonsist on eaeh side of a short basal segment bearing two lamella; the inner lamella is almost four times as long as broad, with nearly parallel sides, eiliated at and near the tip; the outer, which is also in frout of the inner, is sub-oval with the outer margin more convex than the inner, eiliated near the tip and along most of the outer margin, and inserted a little obliquely upon the basal segment. The next three pairs of pleoporls are similar to the first pair on each side, except that in the males the seeond pair (pl. IX, fig. 57 d) bears a stylet $(s)$ articulated to the inner margin of the inner lamella about the middle. The posterior pair of pleopods are smaller than the others and not eiliated.

Length $4.5^{\mathrm{mm}}$; breadth $1.5^{\mathrm{mm}}$; eolor light grayish.

Inch has been written upon the destruetive habits of the Limnoria or "gribble" and the means of preventing its attacks on woodwork, for which the reacler may cousult espeeially the publieations of Leach, Coldstream, Hope, Thompson, Moore, Gould, Bate and Westwood, Verrill, and Andrews, who has observed it attacking the gutta-percha of submarine telegraph cables. 
It is found boring in submerged wood along our coast from Florida! to Halifax!, N. S., and the Gulf of St. Lawrence. It occurs above lowwater mark, but does not usually live far below that line; it has, howerer, been found by Professor Verrill at a depth of 10 fathoms in Casco Bay, and was dredged by the U.S. Fish Commission in a depth of $7 \frac{1}{2}$ fathoms, Cape Cod Bay!, Mass., in the summer of 1879 . It is abundant, aceording to Enropean authors, in many loealities on the eoast of Great Britain and in the North Sea. L. uncinata Heller, from Verbosea, in the Island of Lesina, Adriatie Sea, appears to be the same species, as the differences pointed out by Heller do not really exist, but were doubtless suggested by the ineorreet figures that have been published representing the uropods with rami eomposed of two or more segments. The form of these appendages, as shown on plate IX, fig. $57 b$, corresponds well with Hel. ler's description. It was found by Heller associated with Chelura terebrans. Limnoria is said also to oceur in the Paeific Ocean, and from its habits might be expected to have a wide distribution.

Specimens examined.

\begin{tabular}{|c|c|c|c|c|c|c|}
\hline 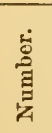 & Locality. & Habitat. & $\begin{array}{l}\text { When col- } \\
\text { lected. }\end{array}$ & Received from- & 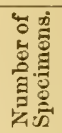 & $\begin{array}{l}\text { Dry. } \\
\text { Alc. }\end{array}$ \\
\hline 2048 & $\begin{array}{l}\text { Florida } \\
\text { Provincetown, Mass ..... } \\
\text { Casco Bay } \\
\text { Bay of Fundy .............. } \\
\text { Halifax, N. S ........... }\end{array}$ & 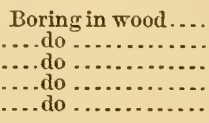 & $\begin{array}{l}\text { Aug., } \\
\text { 二, } 1879 \\
\text { 二, } 1872 \\
\end{array}$ & 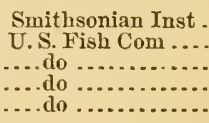 & $\begin{array}{r}6 \\
00 \\
30 \\
00 \\
00\end{array}$ & $\begin{array}{l}\text { Alc. } \\
\text { Alc. } \\
\text { Alc. } \\
\text { Alc. } \\
\text { Alc. }\end{array}$ \\
\hline
\end{tabular}

\section{IX.-CIROLANID AE.}

Front formed of the approximate basal segments of the antennulæ, which are not covered by an anterior projection of the head; antennulæ and antenni presenting an evident distinetion into peduncular and flagellar segments; maxillipeds with a five-jointed palpus; mandibles formed for biting, palpigerous; legs all terminated by nearly straight dactyli; epimera distinct behind the first thoracie segment; pleopods at least the anterior pairs, eiliated; mopods biramous, the rami flattened and ciliated.

This family is represented on our coast by two elosely allied species apparently belonging to the typical genus Ciroluna, although approaching the allied genus Conilera, to which I formerly referred them. They have been hitherto usually referred to the following family, but the differences in the structure of the month parts, first pointed out by Schiöite, seem to warrant their separation as a distinct fumily. The mandibles are formed for biting, being armed with long and powerful teeth, which, closing together like the blades of scissors, are well adapted tor lacerating the flesh of fishes on which they feed. The first three pairs of legs are fitted for prehension, but they are destitute of the strongly eurved 
dactyli found in the Égide, and still butter developer in the Cymothoida. In the Cirolanide the propodus, in the first three pairs of legs, is somewhat eurverl and the dactyli are nearly straight, so that while the first three pairs of legs are powerful organs of prehension, they are also capable of letting go preparatory to the seizure of another victim. The posterior pairs of legs are ambulatory or fitted for swimming by their form and armature of bristly hairs. The eiliated pleopods are also powerful swimming organs, so that these animals are well fitted for the predatory life they lead. The epimera are well separated by sutures in all the thoracic segments behind the first. The pleon is scarcely narrower at base than the last thoracic segment, and is composed of six distinct segments, of which the last is much the longest, but not broader than the preceding segments, and tapers posteriorly. The uropods are lateral, articulated near the base of the last segment and distinetly biramous.

The mouth-organs of this and the tro following families have been the object of special research by J. C. Schiödte, whose papers in the Naturhistorisk Tidsskrift have been in part translated in the Annals and Magazine of Natural History. He regards Cirolana as representing "the highest derelopment of the crustacean type among the Isopoda," and even hints that Cirolana and $A g$ ga should be remored to opposite ends of the series of Isopoda. The same author would closely unite the Bopyridce, Ega, and the Cymothoidce into a single group, the Cymothoce, while acknowledging that the young of Cymothou ostrum, "according to the classification hitherto current, *** would rather be allied to Cirolana than to Cymothoa." His classification, however, appears to be based almost entirely upon the strueture of the mouth, disregard. ing the totality of structure upou which alone morphological classification can securely rest. In deferenee, however, to his views I havo here regarded Cirolana as the type of a distinct family, which must still be considered as closely related with the two following families, on the principle that it is "more important that similarities should not be neglected than that differences should be orerlooked."

Among the more important of the similarities by which these families seem to be united may be mentioned the following, as exemplified by our species. The segments of the thorax and pleon are all distinct from each other, so that the body, in the adults, appears to consist of thirteen segments behind the head, although in the genus Ourozeulites Edwards* the segments of the pleon are consolidated. The epimera are distinct in all the segments behind the first thoracic. The pleon may or may not taper from the base, but it is terminater by a large seutiform segment, sometimes more or less sculptured, and bearing at the sides, near the base, a pair of uropods, in which the basal segment is more or less oblique distally and the rami lamelliform, thongh one of them may be narrowly so. The pleopods are unprotected by any form

* Hist. nat. des Crust., tome iii, p. 275, 1840. 
of operculum and the anterior pairs are ciliated in the young of all three families, but this ciliation, as well as that on the uropods, may be lost in the sedentary adults of the Cymothoidc. In all our species the dorsal surface is smooth throughout, or minutely punetate under a lens, but destitute of distinet roughness, tubereulation or seulpture, except that the telson may be faintly grooved or seulptured, and in some foreign species more distinctly so.

\section{Cirolana Leach.}

Cirolana Leach, Dict. des Sci. nat., tome xii, p. 347, 1818.

Thoracic segments subequal; eyes small, well separated; mandibles armed with strong aeute teeth; daetyli straight, or but slightly eurved; pleon of six distinet segments; basal segment of uropods with the inner angle produced.

Two closely allied species are found on this coast, which I formerly referred to the genus Conilera Leach. Further consideration induces me to refer them rather to the present genus, although they have some features which point toward Conilera, and are perhaps between that genus and the typical forms of Cirolana. From Conilera, as described by Bate and Westwood, our species differ principally in the more robust four posterior pairs of legs, in the produced angle of the basal segment of the uropods, and in the structure of the first pair of pleopods, which are not opereuliform either in size or texture. Of these two species one is abundant and is described at lengtl. The deseription will, however, apply almost equally well to the other except in the few points mentioned in the appropriate place. The characters given, though slight, appear to be constant, and I have therefore retained the tro speeific names.

This genus differs from AEga in the structure of the legs, and was placed by Professor Dana in a separate subfamily. In Cirolana the first three pairs of legs are strong, and armed with minute spine-like claws at the tip of the nearly straight dactyli; the propodi in these legs are robust, spiny, and somewhat eurved, and some of the preceling segments are also armed with spines. These legs thus form powerful organs for seizing living prey, and are not, as in the Cymothoidle, and, in a less degree, in AEga, merely fitted by their curved dactyli to retain the hold of the animal upon its host in a parasitic existence. The last four pairs of legs are well ciliated and capable of use either for walking or swimming, and these animals are thus fitted for their active and predaceous life.

Cirolana concharum Harger (Stimpson).

Ega concharum Stimpson, Mar. Inv. G. Manan, p. 42, 1853.

Lütken, Vidensk. Meddel., 1859, p. 77, 1860.

Conilera concharum Harger, This Report, part i, p. 572 (278), 1874.

Verrill, This Report, part i, p. 459 (165), 1874.

Cirolana concharum Harger, Proc. U. S. Nat. Mus., 1879, vol. ii, p. 161, 1879. 
Plates IX and X, Figs. 58-63.

This species may be most readily recognized among our Isopoda by the distinet thoracic and abdominal segments, the small lateral eyes, and the evident distinction, in both antennula and antenna, of peduncle and flagellum. From the next species it is distinguished by the tip of the telson, which is trumeated, or slighty emarginate, and grooved on the median line above near the end.

The body is, when extended, about three times as long as broad, and is smooth and polished throughout. The head is quadrate, a little broader in front than behind, and embraced at the sides by the first thoracic segment. The ejes are triangular, with the angles rounded, aud are often partially eovered below by the projecting anterior lobes of the first thoracic segment. They are separated by about three times their longest diameter. The antennula (pl. X, fig. 60) are robust, with their basal segments in contact; the first segment is short and sub-spherical; the second also short; the third eylindrical and as long as the first two taken together and followed by a robust, but short, tapering flagellum, consisting of about fifteen segments, of which the second is as long as any other two, but the rest are all short. The flagellar segments beyond the first are provided each with a tuft of "olfactory setr." The antennæ (pl. X, fig. $61 \mu$ ) are longer and more slender than the antemmlie, and are separated at their bases. The first four pedumeular segments are robust; the first two short; the third and fourth each about twice as long as the first or second, and the fifth or last peduncular segment slightly the longest and much the most slender. The fourth and fifth segments bear along the distal portion of their outer margins long bristle-form hairs. The flagellum is slender and composed of from 15 to 18 segments, each bearing a few short bristles. The maxillipeds (pl. X, fig. 62 a) are elongater and almost pediform but flattened; the external lamella is small and subtriangular, rounded and liairs at the tip; the palpus is five-jointed, with the last four segments broad, flattened, and well ciliated; the tip of the maxilliped, nearly concealed by the large palpus, is provided with very densely plumose bristles. The onter maxillie (pl. X, fig. $61 \mathrm{~b}$ ) are short and robust; the two articulated lobes narrow ovate, rounded at the tip, armed, especially the iumer one, with spines and plumose or pectinated bristles. The inner maxilla (pl. X, fig. $61 \mathrm{c}$ ) are robust, with the outer lobe armed with strong smooth spines; the inner lobe rounded at the end and bearing three straight rather blunt spines, densely covered toward the tip with soft hairs. The mandibles (pl. X, figs. $61 d$ ) are robust and horny at the tip, armed with one strong acute tooth, and in the right mandible with one acute and one obtuse tooth along a cutting edge, while the left mandible has three less acute teeth along this edge. Each mandible is, moreorer, provided with a molar process or area $(m)$, on its inner surface set along its interior and upper margin with spines. A narrowly lanceolate leaflike appendage is attached just below the molar area. This appendage 
is furnisherl with a few bristles near the base, and its npper edge is armed with minnte denticles; it is movable and ordinarily concealed behind the mandible. On the external surface, just above the origin. of the palpus, each mandible bears two elevated, conical, obtuse tubereles. The palpi are slender, the second segment longest and hairy on the margin beyond the middle, the last segment slender and eurved, with the usual hair's or slender bristles along the inner curvature.

The second and third thoracic segments are a little shorter than the others, which are of about equal length. The fourth and fifth seginents are widest. The first segment is produced at the sides around the head so as to very nearly attain the anterior lateral angles of the head, and often so as to obseure the lower margin of the eyes. The epimeral sutures are scarcely distinguishable in this segment, but evident in the following segments. The epimera are rounded behind as far as the fourth, but the fifth is slightly angulated, and the sixth and seventh acute and produced backward beyond the margin of the eorresponding segment. The first pair of legs are short and stout, and well armed with spines and bristles; the basis is of the ordinary form ; the ischium is nearly triangular, having the upper margin much produced in the distal portion and bristly ; the merus is expanded in a somewhat similar manner, but the angle is bent forward beyond the short carpus over the base of the propodus; the opposite or lower margin of the merus is armed with short stout spines; the carpus is short aud small and possesses but little motion on the propodus, which is robust, somewhat eurved, and bears a strong short dactylus. The second and third pairs of legs resemble the first pair, but the earpus increases somewhat in size, and there is more motion in its articulation with the propodus. They are directed forward, while the remaining pairs are usually directed backward and are more flattened. The fourth pair of legs are short like the first three (pl. X, fig. 62 b), but, except in size, resemble the following pairs. They are well provided with bristles in tufts, and along the margins of the segments, and especially the merus and two adjacent segments, are armed with long stout spines. The propodus is straight and much more slender than the earpus. The fifth and sixth pairs of legs increase in size, and the propodus especially becomes more elongated, but the seventh pair are a little smallex than the sixth.

The pleon is scarcely narrower at base than the last thoracic segment, and the first segment is often nearly concealed by the last thoracic. The fifth segment is longer on the back but shorter at the sides than the preceding segments. The last segment, or telson, is triangular with the ciliated apex truneated and emarginate or notehed at the end of a short median furrow at the tip. The uropods (pl. X, fig. 63) slightly surpass the telson and are strongly ciliated; the inner ramus bears also a few spines near the tip; the basal segment has the inner angle produced aloug the margin of the inner ramus, which is broad and expanded 
distally, with a notch at the external angle; the outer ramus is slender and tapering, slightly surpassing the immer.

Length of large specimens $32^{\mathrm{mm}}$, breadth $10^{\mathrm{mm}}$, but usually smaller; $22^{\mathrm{mm}}$ long, $7^{\mathrm{mm}}$ broad. The ground color in life is yellowish, with redlish brown on the anterior margin of the head and on the posterior margins of the segments, especially in the clorsal region, where the segments are also marked with black dots. In life the body is somewhat translucent in the thinner parts. In alcohol the translncence disappears and the color fades to a nearly muiform yellowish or buff with black dots.

This species was described by Stimpson from Charleston, S. C. Most of the specimens in the collection are from Vineyard Sound!, where it occurs sometimes in great abundance, and is common especially during the winter. It is found swimming about in shallow water, and may be taken in a scoop-net, and is found also in lobster-pots. It was dredged in 45 fathoms off Block Island!, near the eastern end of Long Island Sound, in 1874, but has not yet been found north of Cape Cod.

Specimens examined.

\begin{tabular}{|c|c|c|c|c|c|c|c|}
\hline 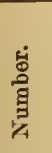 & Locality. & 离 & Bottom. & $\begin{array}{l}\text { When col- } \\
\text { lected. }\end{array}$ & Received from- & 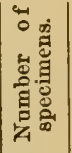 & $\begin{array}{l}\text { Dry. } \\
\text { Ale. }\end{array}$ \\
\hline $\begin{array}{l}2061 \\
2060 \\
2065 \\
2062 \\
2063 \\
2064\end{array}$ & 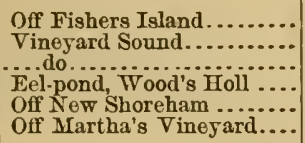 & S. f. & 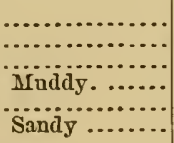 & $\begin{array}{l}\text { May -, } 1875 \\
\text { Mar. }, 1874 \\
\text { Aug. 25, 1875 } \\
\text { July 23, 1875 } \\
\text { Aug. 19, 1874 } \\
\text { Sept. 20, 1875 }\end{array}$ & 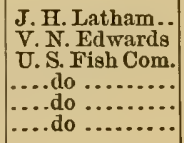 & $\begin{array}{c}100+ \\
10 \\
1 \\
100+ \\
1 \\
1\end{array}$ & $\begin{array}{l}\text { Alc. } \\
\text { Alc. } \\
\text { Alc. } \\
\text { Alc. } \\
\text { Alc. } \\
\text { Alc. }\end{array}$ \\
\hline
\end{tabular}

Cirolana polita Harger (Stimpson.)

AEga polita Stimpson, Mar. Inv. Grand Manan, p. 41, 1853.

Lïtken, Vidensk. Meddel., 1859, p. 77, 1860.

Verrill, Am. Jour. Sci., III, vol. v, p. 16, 1873.

Conilera polita Harger in Smith and Harger, Trans. Conn. Acad., vol. iii, pp. 3, $22,1874$.

Verrill, Am. Jour. Sci., III, vol. vii, p. 411, 1874.

Cirolana polita Harger, Proc. U. S. Nat. Mus., 1879, vol. ii, p. 161, 1879.

This species so closely resembles the preceding, that a full description would be little else than a repetition of that given above. It appears, however, to differ constantly from the form already describel, by its somewhat more elongated and cylindrical body; in the eyes, which are "elongate trapezoidal in shape, narrowest anteriorly," and in the tip of the telson, which is regularly rounded or slightly pointed at the tip without any truncation, much less any emargination, and is not at all grooved above.

Length $25^{\mathrm{mm}}$, breadth $6.5^{\mathrm{mm}}$; color much as in the preceding species.

Dr. Stimpson's specimens were "found on the fine sands at low-water mark on High Duck Island," in the Bay of Fundy, and the specimens that I have examined are from Cape Cod Bay!; from near Salem!, Mass. ; 
George's Banks!, and east of Banquereau!, or Quereau, latitude $40^{\circ} 36^{\prime}$ north, longitude $57^{\circ} 12^{\prime}$ west, where seven fine specimens were taken from a halibut (Hippoglossus), June 2, 1879, by Capt. J. W. Collins. It appears to replace the preceding species at the north.

Specimens examined.

\begin{tabular}{|c|c|c|c|c|c|c|c|}
\hline $\begin{array}{l}\text { 峁 } \\
\text { 竞 }\end{array}$ & Locality. & 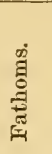 & Bottom. & $\begin{array}{l}\text { When col- } \\
\text { lected. }\end{array}$ & Recoivedfrom- & 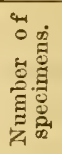 & $\begin{array}{l}\text { Dry. } \\
\text { Alc. }\end{array}$ \\
\hline & Cape Cod Bay................ & 7 & Coarse, yellow & Sept. 15,1879 & U.S. Fish Com. & 2 & Alo. \\
\hline 1314 & $\begin{array}{l}\text { George's Bank, lat. } 41^{\circ} 40^{\prime} \\
\text { N. } 68^{\circ} 10^{\prime} \mathrm{W} .\end{array}$ & 25 & Sand... &,-- 1872 & $\begin{array}{l}\text { Smith and Har- } \\
\text { ger. }\end{array}$ & 1 & Alc. \\
\hline 1399 & $\begin{array}{l}\text { Georges Bank, lat. } 42^{\circ} 11^{\prime} \\
\text { N., lon. } 67^{\circ} 71^{\prime} \mathrm{W} .\end{array}$ & 150 & $\begin{array}{l}\text { Soft, sa a d y } \\
\text { mud. }\end{array}$ &,-- 1872 & $\begin{array}{l}\text { Packard and } \\
\text { Cooke. }\end{array}$ & 1 & Alo. \\
\hline & $\begin{array}{l}\text { Salem, Mass.................. } \\
\text { East Quereau ................ }\end{array}$ & $190^{\circ}$ & & $\overline{\operatorname{Jun} \theta}=1878$ & $\begin{array}{l}\text { J.H. Emerton. } \\
\text { Capt.J. W.Col- } \\
\text { lins. }\end{array}$ & $\begin{array}{l}1 \\
7\end{array}$ & $\begin{array}{l}\text { Alc. } \\
\text { Alc. }\end{array}$ \\
\hline
\end{tabular}

\section{X.一AGID无.}

Front formed of the approximate basal segments of the antennulæ, which are not corered by an anterior projection of the head; antennulæ and antennæ presenting an erident distinetion into pedunenlar and flagellar segments; maxillipeds operculiform; mandibles formed for piercing, palpigerous, mouth suctorial ; first three pairs of legs ancoral, last four ambulatory; epimera distinct behind the first thoracic segment; uropods lateral, biramous, ciliated, and flattened.

This family was represented within our limits by a single speeies of the typical genus until the summer of 1879 , when a single specimen was collected of a second genus belonging to the Eigicle, but having evident relations with the next family, and in many characters intermediate between AEga and the Cymothoidre. The two genera by which the family is at present represented on our coast may be further characterized as follows: Both the antennula and the antenna are directed laterally, the former arising near together on the anterior margin of the head and forming part of the outline of the animal as seen from abore. They, as well as the antennæ, present an evident distinction into peduncular and flagellar segments. The maxillipeds are operculiform, and have the palpus armed with short hooks for adhesion to the surface of the fish on which they may be feeding. The mandibles are armed with a horny point, but not toothed as in the Cirolanida, and, while fitted for piercing, are not capable of lace:ating and biting off pieces of flesh as in that family.

The first three pairs of legs are ancoral, or armed with strong eurred dactyli, which, once implanted in the body of a victim, retain their hold without effort-a structure which attains its fullest development in tho. 
following family. The remaining pairs of legs are fitted for walking. The thoracic segments are subequal in length aud have the epimera well separated, except in the first segment.

The pleon may or may not be suddenly narrower than the last thoracie segment, and, in onr species, is composed of six distinct segments, of which the last is large and seutiform. The uropods are composed of a basal segment, oblique at the apex with the inner angle more or less prodhced, and bearing two flattened, ciliated rami; they are distinctly lateral, being inserted high up on the sides of the last segment.

This family contains our largest Isopod, Ega psora, and to it should probably be referred the huge Bathynomus giganteus A. Edwards, from the Gulf of Mexico, measuring more than eleven inches in length. It has usually been regarded as embracing the Cirolanidce. I have already given my reasons for separating them, but have to regret my inability to examine many types of genera apparently more or less intermediate in position between Ega aud, on the one hand Cirolana, and on the other Cymothoa and Lironeca. I have therefore retained the old classification rather than to unite the following genera with the Cymothoides.

Our two genera are most easily distinguished as follows: Eyes large and approximate, Agga, 1. 89; eyes wanting, Syscenus, p. 93.

\section{झפga Leach.}

Eya Leach, Trans. Linn. Soc., vol. xi, p. 369, 1815.

Eyes large; palpus of maxillipeds five-jointed ; three anterior pairs of legs terminated by strong curved claws; posterior pairs slender, with slender nearly straight dactyli; pleon not suddenly narrower than the thorax; pleopods ciīiated.

This genus is represented within our limits by a single species, which may be easily distinguished by its large approximate eyes. The basal segments of the antennulie are flattened and the flagellum is comparatively slender. The maxillipeds have a five-jointed palpus, which is short and flattened and bent around the oral opening, and the inner margins of the three terminal segments are provided with a row of strong hooked spines, which are also foumd npon the outer maxillæ, thus forming two rows of short hooks on each side of the moutl, by means of which the opening of the month can be elosely applied to the fish on which these animals prey. The inner maxille are sleuder and styliform and armed with sharp curved spines at the apex, and the mandibles are also acute and fitted for piercing. The body is moderately convex, and the last four pairs of legs are nearly alike ambulatory and of moderate length, the last pair, when extended, scarcely surpassing the telson. The pleon is composed of six distinct segments, and the basal segment of the uropods is strongly produced at its inner angle, as usual in the family. The pleopods are ciliaterl in the adults as well as in the young. 
Aga psora Ḱröyer (Linné).

Oniscus psora "Linné, Famna sueeica, ed. ii, 1761"; Syst. Nat., ed. xii, tom. i, p. $1060,1767$.

"Penuant, Brit. Zool., vol. iv, pl. 18, fig. 1, 1777 (certe)" (B. \& W.).

O. Fabricius, Fanna Grœnlandiea, p. 249, 1780.

Mohr, Islandisk Naturhistorie, p. 110, 1786.

Liga emarginata Leaeh, Trans. Linn. Soc., vol. xi, p. 370, 1815; Diet. Sei. nat., tome xii, p. 349, 1818.

Samonelle, Ent. Comp., p. 109, 1819.

Desmarest, Consicl. Crust., p. 305, pl. 47, figs. 4, 5, 1825.

Griffith and Pilgeon, Nat. Hist. Crust., p. 218, pl. viii., fig. 3, 1833.

Edwards, Hist. nat. des Crust., tome iii, 1. 240, 1840; Regne Anim., Crust., pl. iv, fig. 4, and pl. lxvii, fig. 1, 1849.

Gould, ?Rep. Geol. Mass., 1. 549, 1४35; Invert. Mass., p. 338, 1841.

Gosse., Man. Mar. Zool., vol. i, p. 134, 1855.

AEga (Oniscus psora) Kröyer, Grönlands Amfipoder, p. 318, 1838.

EEga psora Lilljeborg, Öfvers, Vet.-Acad. Förh., 1850, p. 84, and 1851, p. 24.

Luitken, Vidensk. Meddel., 1858, pp. 65, 179, 1859; ibid., 1860, p. 181 (7) 1861 ; Crustaeea of Greenland, p. 150, 1875.

Sehiölte, Ann. Mag. Nat. Hist., IV, vol. i, p. 12, 1868.

Bate \& Westwood, Brit. Sess. Crust., rol. ii, p. 283, figure, 1868.

M. Sars, Chr. Vid. Selsk. Forh., 1868, p. 261, 1869.

G. O. Sars, Hard. Famna, Crust., p. 275 [32], 1872.

Verrill, Am. Jour. Sei., III, vol. v, p. 16, 1873.

Smith and Harger, Trans. Conn. Aead., vol. ii, p. 22, 1874.

Whiteaves, Further Deep-Sea Dredging, Gulf St. Lawrenee, p. 15, "1874."

Metzger, Nordseefahrt der Pomm., p. 285, 1875.

Meinert, Crust. Isop. Amph. Dee. Daniæ, p. 89, "1877."

Miers, Ann. Mag. Nat. Hist., IV, vol. xix, p. 134, 1877.

Harger, Proe. U. S. Nat. Mus., 1879, vol. ii, p. 161, 1879.

Egga evitaillée Latreille, Règne Anim., tome iv, p. 134, 1829.

Plate X, Fig. 64 .

The present species is the largest Isopod, and indeed the largest Tetradecapod known on the New England coast, reaching a length of nearly or quite two inches and a breadth of one inch, and has even at. tained to the dignity of a popular name, "salve-bug", by which it is known among fishermen. It may be further distinguished by its large approximate eyes, eovering a large proportion of the upper surface of the head, and by the possession of ancoral legs in three pairs only, the last four pairs of legs being fitted for walking.

The body is oval, broadest at the fourth and fifth thoracic segments, where the brealth is about half the length. The dlorsal surface is moderately eonvex and smooth except for minnte and rather scattered punctations, which occur also on the legs, especially on the basal segments, on the antennulie, the uropods, and eren the pleopods. The head is transverse and sub-triangular, salient in front between the bases of the antemnula. Much of the upper surface of the head is covered by the large oval or somewhat reniform eyes, which do not quite meet on the median line. The antennula when bent backward ncarly or quite attain the anterior margin of the first thoracic segment, and 
have their first two segments large and flattened, and wedge-shaped in front; of these the basal segment is quadrate in outline, as seen from above, and nearly as broad as long; it closely approaches its fellow of the opposite side in front, but is separated from it behind by a median process of the head; the second segment is triangular in outline, as seen from above, with the apex of the triangle extending beyond the origin of the third slender cylindrical segment, which is followed by a tapering flagellum of about a dozen segments. The antennie when reflexed extend beyond the first thoracic segment and have the first two segments short and compressed, the third somewhat longer, the fourth and fifth longer and nearly cylindrical, followed by a tapering flagellum about as long as the peduncle and composed of fifteen to trenty seg. ments. The maxillipeds have a short triangular external lamella and a five-jointed palpus, of which the first segment is short and transverse; the second is triangular and bears, on its inner apex, a few slender hooked spines; the third segment is broad and flattened, with the inner margin short, and armed with about three robust hooked spines; the fourth segment is flattened and transverse and armed along its inner margin with about six similar spines; while the fifth segment is small, sub-oval, and armed with much more slender curved spines. The outer maxilla are provided with curved spines at the apex much like those of the maxillipeds. The inner maxillio are rod-like and terminate in sharp somewhat curred spines placed close together. The mandibles support a slender palpus of three segments, of which the middle one is much the longest, and the last is robust and sickle-shaped, with a comb of short spines along the inner curve. This segment lies, in the ordinary position, just at the base of the antenna of the same side.

The first thoracic segment is, at its anterior margin, scarcely broader than the head, but expands rapidly backward. It is excavated in front for the eyes, which project somewhat beyond the posterior margin of the head. The second, third, and fourth thoracic segments are each a little shorter than the first; the fifth and sixth are somewhat longer; the seventh is shorter than the sixth. The epimera of the first thoracie segment are not separated by suture, but in the second and following segments they are so separated, and, especially on the anterior segments, marked with two oblique depressed lines. The epimera of the second, third, and fourth segments are rounded or truncate behind, but in the posterior segments they become acute and extend beyond the angles of the segments to which they are attacherl. The first three pairs of legs are short and armed with strong hooked dactyli. The propodal segments are also curver, and the carpus is short in the first pair but somewhat longer in the second and third pairs. The merus is almost erescent-shaped in the first pair of legs, its horns embracing the carpus above and below, but it becomes more elongated in the succeeding pairs; in all three pairs its inferior margin is armed with a few short, stout spines. The fourth and succeeding pairs of legs are of quite a different 
type from the first three. The four segments following the first or basal one are straight, eylindrical, or slightly compressed, armed with short, spines, especially below and at the distal end, subequal in length but decreasing in diameter to the propodus, which bears in each pair a short, slightly curved and comparatively weak dactylus. The seventh pair is only imperfectly dereloped in the young specimen figured, but never quite attains the size of the sixth pair, which is the largest.

The pleon is seareely narrower than the last thoracic segment and tapers but little to the fifth segment. The last segment is triangular, with the sides but little dilated, and is pointed at the tip withont grooves or carinations. The uropods scarcely surpass the telson; the basal segment has its inner angle long and spiniform, extending the whole length of the inner margin of the inner ramus and eiliated toward the tip; the rami are flattened, the outer elongate ovate, obtuse; the inner with the inner margin straight, the outer curved and emarginate near the tip. Both rami aud the posterior part of the telson are ciliated.

Length $16-50^{\mathrm{mm}}$, breadth $7-25^{\mathrm{mm}}$; color in alcohol light brown, darker toward the hear ; eyes black.

Linnés description of Oniscus psora is too indefinite to be certainly recognizable, and in using his trivial name I have followed the authority of Liitken and others. Our specimens agree well with the description of 0 . psora by $O$. Fabricius, and are undoubtedly identical with that species, which he describes as infesting the cod. They appear to correspond also with Bate and Westwood's figure and deseriptions, although those authors make no mention of Fabricius under AE. psora. As Kröyer referred the species to its proper genus, I have adopted his name as authority for the combination.

The specimen figured was dredged in the summer of 1872 , a little to the northeast of St. George's Bank!, in latitude $42^{\circ} 11^{\prime}$ north, longitude $67017^{\prime}$ west, in 150 fathoms, soft sandy mud with a few pebbles, and is young, as shown by its size and imperfectly developed seventh pair of legs. Adults may surpass the size of the figure, but the specimen drawn was enlarged three diameters. Adult specimens were obtained from the Prorincial Museum, Halifax, Nova Scotia, labeled as found on the cod, and were probably from the fishing banks of that region, or from the Banks of Newfoundland. During the summer of 1879 a considerable number of specimens were received by the Fish Commission throngh the Gloncester fisheries, of which only a few are included in the table of specincus examined. These specimens were parasitic on the cod (Gadus morrhua), and on the halibut (Hippoglossus). Specimens have also been obtained from the skate (Raia). Whiteares recorts this species from a halibut, on the north shore of the Gulf of St. Lawrence. Fine specimens were obtained by Mr. N. P. Scudder from off Holsteinborg, Greenland, in Davis' Straits!, parasitic on the halibut, and collected in July and August, 1879. It extends to Iceland (Edw. et al.); the British Isles (B. and W.); the North Sea (Metzger); Finmark (Sars), and Spitzbergen (Miers). 
Specimens examined.

\begin{tabular}{|c|c|c|c|c|c|c|c|}
\hline $\begin{array}{l}\text { 㟔 } \\
\text { 苜 } \\
\text { 总 }\end{array}$ & Locality. & 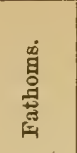 & Parasitic on- & $\begin{array}{l}\text { When col. } \\
\text { locted. }\end{array}$ & Received from- & 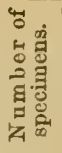 & $\begin{array}{l}\text { Dry. } \\
\text { Alc. }\end{array}$ \\
\hline 1398 & $\begin{array}{l}\text { George's Bank, lat. } \\
422^{\circ} 1^{\prime} \text { N., lon. } 67^{\circ} \\
17^{\prime} \text { W. }\end{array}$ & 150 & &,-- 1872 & Packard and Cooke & 1 & Alc. \\
\hline \multirow[t]{4}{*}{2139} & . & & & & $\begin{array}{l}\text { Colonial Mus., Hal- } \\
\text { ifax. }\end{array}$ & 2 & $\Delta l o$. \\
\hline & George's Bank....... & & &,-- 1878 & Schooner Alice G. & 3 & Alc. \\
\hline & $\ldots$ & & 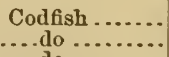 & $\begin{array}{l}\text { May } 8,1879 \\
\text { May } 15,1870\end{array}$ & $\begin{array}{l}\text { J. 1'. Shemelia ... } \\
\text { Capt.J.Q. Getchell }\end{array}$ & $\begin{array}{l}3 \\
9\end{array}$ & $\begin{array}{l}\text { Alc. } \\
\text { Alc. }\end{array}$ \\
\hline & $\begin{array}{l}\text { N. E. George's Bank. } \\
\text { Gulf of Mraine.......... }\end{array}$ & & Skate $($ Raia $) ..$ & $\begin{array}{l}\text { Nov. } 29,1878 \\
-, 1878\end{array}$ & $\begin{array}{l}\text { J. P. Shemelia..... } \\
\text { U.S. Fish Com'n .. }\end{array}$ & $\begin{array}{r}3 \\
20\end{array}$ & $\begin{array}{l}\text { Alc. } \\
\text { Alc. }\end{array}$ \\
\hline 2156 & Janquerean............ & 50 & Halibnt......... &,- 1878 & Schoonor Mfarion .. & 1 & Alc: \\
\hline & .............................. & $40-50$ & Codfish ........ &,- 1878 & $\begin{array}{l}\text { Schooner Rebecca } \\
\text { Bartlett. }\end{array}$ & 1 & Ala: \\
\hline 2158 & Grand Menan Bank... & 100 & &,-- 1878 & $\begin{array}{l}\text { Schooner Peter D. } \\
\text { Smith. }\end{array}$ & 3 & Alc. \\
\hline \multirow[t]{3}{*}{2155} & Brown's Bank. .......... & $\begin{array}{r}100 \\
52\end{array}$ & Codfish . & $\begin{array}{l}\text { Dec. } \\
\text { Feb. }, 1878,1878 \\
\text { Feb }\end{array}$ & $\begin{array}{l}\text { U. S. Fish Com'n .. } \\
\text { Mr. Isaac Butler } \\
\text { Capt. J. Q. Getchell }\end{array}$ & $\begin{array}{l}1 \\
2 \\
2\end{array}$ & $\begin{array}{l}\text { Alc. } \\
\text { Alc. } \\
\text { Alc. }\end{array}$ \\
\hline & Lat. $43^{\circ} 25^{\prime}$ N., Lon. & $\begin{array}{r}30 \\
180\end{array}$ & Halibut .... & $\begin{array}{l}\text { May } 1,1879 \\
\text { Ang. 21, } 1879\end{array}$ & Capt. S. W. Smith & $\begin{array}{l}8 \\
\cdots\end{array}$ & $\begin{array}{l}\text { Alc. } \\
\text { Alc. }\end{array}$ \\
\hline & Davis's Straits........ & & ... do .... &,-- 1879 & $\begin{array}{l}\text { and crow. } \\
\text { Mr. N. P. Scudder }\end{array}$ & 10 & Alc. \\
\hline
\end{tabular}

Syscenus* gen. nov.

Eyes wanting; palpus of maxillipeds two-jointed; sixth and seventh pairs of legs elongated; pleon suddenly narrower than the thorax; pleopods naked.

This genus is unfortunately represented in the collection by a single specimen. It differs from EEga by characters that point toward the Cymothoidce, as in the rerluction of the segments of the palpus of the maxillipeds, the sudden constrietion at the base of the pleon, and the naked pleopods. The absence of eyes, although a conspienous character ean hardly be regarded as of great taxonomic value. It is separated from the Cymothoidce by the form of the head, which is not produced over the bases of the antennulio but merely projects slightly between them. The antennulæ moreover are composed of three peduncular segments and a flagellum; the basal segments are much smaller than in EEga and less flattened, but still form a part of the anterior outline when seen vertically. The last four pairs of legs differ from the first three, and are more or less elongated and fitted for crawling. The uropods are distinctly ciliated.

\section{Syscenus infelix sp. nov.}

This species may be recognized among our Isopoda by the possession of the full number of segments, the ciliated uropods, naked pleopods, and the absence of eyes. 
The body is more than twice as long as broad and only moderately convex. The head is small and as seen from above is transversely somewhat diamond-shaped with rounded angles. It presents in front a slight prolongation between the antennula, and on each side of the short median process its outline is excavated above the bases of the antenmula. The posterior margin is curved, but near each end is a faint indication of a lobe, projecting backward like the ocular lobes in Ega, but the eyes are wanting. The antennulie arise near together on each side of the front and are short, extending when reflexed but little beyond the lateral margins of the head and only slightly surpassing the fourth antennal segment. They are readily distinguishable into peduneular and flagellar segments, the first three segments being of comparatively large size and about equal length; the second segment much flattened below against the antennx; third more slender than the first two and followed by a short, tapering six-jointed flagellum. The antennulx are in their natural position reflexed, the second segment being artieulated at an angle with the first. The antenna are considerably longer than the antennulæ and, when reflexed, slightly surpass the posterior border of the third thoracic segment. They are inserted below and a little outside of the antemnula. The first segment is short and flattened below; the second is also short, the two together being hardly longer than the basal antennular segment; the third segment is about as long as the first two together, and the fourth is a little longer than the third, but of slightly less cliameter; the fifth is more than one-half longer than the fourth, but is more slender and is followed by a slender, tapering flagellum of about twenty-four segments. The last two peduncular segments bear a row of elongate bristly hairs along the margin which, when reflexed, is brought next the borly, and the row is continued, though with shorter hairs, along the flagellum. The palpus of the maxillipeds is composed of two segments of which the first is nearly square and armed at the inner distal angle with a minute hook; the second is bluntly triangular and armed at the apex, which is directed inward, with three hooklets. The external lamella is small and subcircular. The outer maxillæ are armed with short looks at the tip; the inner with minute denticles. The mandibles are flattened and denticulate at the tip and bear a three-jointed palpus of which the three segments decrease in size to the last.

The first thoracic segment is twice as long as the second; its anterior margin is adlapted to the head; its posterior margin is nearly straight above and romnded at the sides until the epimeral region is reached, when a short, pointed projection juts backward, being the tip of the epimeron on each side, here united with the segment. The next three - second, third and fourth-thoracic segments are of about equal length, and each a little over half the length of the first segment; their posterior margins are nearly straight above and rounded at the sides; the third segment is broadest. The fifth and sixth segments are each a 
little longer than the second; the seventh abont as long as the second. The last segment, and in a less degree the sixth and fifth segments, have their posterior margins excavated along the back; all have their lateral angles romded, although the angles of the serenth segment are but slightly so. The epimera are short and pointed; those belonging to the second and third segments are larger than the following ones, and are applied directly to the lateral margin of the segmerits; the posterior four pairs of epimera are shorter and smaller, and are separated from the lateral borders of the segment by a fold of the integument cutting off a portion of the anterior lateral angle and increasing in size to the last segment.

The first three pairs of legs are alike, distinetly ancoral and directed forward. In each the basis is much the longest segment; the ischium is strongly flexed upon it; the merus is expanded distally around the base of the carpus and bears a few bristles at the outer angle; the carpus is short, less than half as long as the propodus, and the dactylus is strong and curved. The fourth pair of legs, like those that follow, is directed backward; the basis is the longest segment and the ischium is strongly flexed upon it and of more than half its length; the merus, carpus and propodus are each about two-thirds as long as the ischium, and all four segments are armed distally with a whorl of spines around the articulation with the succeeding segment; the dactylus is slender, sharp and eurved. The fifth pair of legs is longer than the fourth by a little more than the length of the dactylus, the elongation being in the segments from the ischium to the propodus inclusive. The sixth pair is the longest, being, when extended, as long as the thorax and pleon together. This elongation is confined also to the four segments above indicated, and of these the ischimm is abont as long as the basis; the merus falls a little short of the ischimm in length; the carpus and propodus are of equal length, and are as long as the ischium; all these segments are slender and slightly enrred, and are armed distally and along their inner side with short spinules. The dactylus is slender and curred. The seventh pair of legs resembles the sixth but is shorter by about half the length of the propodus. The fifth pair does not attain the middle of the carpus of the sixth.

The pleon is of less diameter than the last thoracic segment and about as long as the last fire thoracic segments. Its transverse diameter inereases slightly to the base of the last segment, where it is broadest; the fifth segment is a little longer than the preceding one, and the last segment is of a broad orate form, acuminate and ciliated at the tip, truncated at the base and smooth abore, except for a faint transverse impression on each side near the base, and a still more faint impressed median line toward the tip. The uropods attain the tip of the telson but do not surpass it; they have the basal segment oblique but not produced at the inner angle, and bearing two elongate-elliptical 
rami, tapering at the base and ciliated, the inner about one-third longer than the outer. The pleopods are quite naked and destitute of eilia.

Length $23^{\mathrm{mm}}$; breadth, $9^{\mathrm{mm}}$; breadth of pleon $4^{\mathrm{mm}}$; length of head $3^{\mathrm{mm}}$; breadth $4.2^{\mathrm{mm}}$.

A single specimen of this species was dredged by the U. S. Fish Commission, about fifteen miles northeast of Cape Cod!, in 130 fathoms brown mud, September 10, 1879.

\section{XI._CYMOTHOID AE.}

Head produced anteriorly over the hases of the antennulæ; maxillipeds few-jointed, operculiform; mandibles palpigerous; mouth suctorial; legs armed with strong curved dactyli; epimera distinct behind the first thoracic segment; telson large and flattened; pleopods not ciliated; uropods articulated near the antero-lateral angles of the last segment, and composed of a more or less flattened basal segment bearing two flattened rami ; habit parasitie; body often unsymmetrical by distortion in the adults.

This family is represented within our limits by three genera and as many species. They are parasitic in habit, usually on fish, and fix themselves by their strongly-curved claws to their host, often within the mouth, or about the branchial cavity, and frequently become distorted when fully grown. In all our species the head is small, and has the anterior margin produced, concealing the bases of the antennulæ and the antenna. The hearl is three-loberl behind, and the first thoracie segment is adapted to it. The antennulæ and antennæ are both short and tapering, withont very evident distinction into peduncular and flagellar segments. This distinction is, however, usually more or less evident on examination.

The epimera are well separated, exeept in the first segment, and may be projecting and conspicuous. The legs are of nearly the same form throughout, but increase in length and beeome more slender posteriorly.* The basal segments are in some genera enlarged and flattened, but not in ours; the joint between the basis and ischium is strongly flexed, and the segments, at least beyond the ischium, to the dactylus, are short and capable of but little motion on each other. The dactylus is strongly curved and admirably fitted for firm attachment to the host on which the animal may be living. In our species the legs, in the natural position, are concealed in a dorsal view beneath the borly of the animal, to the under surface of which they are appressed, the first three pairs being directed forward, and the last three backward, as represented in plate $\mathrm{X}$, fig. 66 .

The pleon in our species is not suddenly narrower than the thorax, as it is, however, at least in the adults, in some genera belonging to this family. The segments of the pleon are distinct, the last one scutiform

"In Artystome Schiölte the seventl pair of legs "reach to the extremity of the tail and are slender, compressed crawling legs, with a small, almost rudimentary, straight claw." 
and of moderate size, not being greatly enlarged. The pleopods are destitute of cilia in the adults.

This family is evidently elosely related to the preeeding and may yet have to be united with it, or even be extended so as to include also the Cirolanida. Our representatives of the three families are so few that I have inad little opportunity to study the genera, and as before stated, I have separated the Cirolanide principally in deference to the opinions of Schiödte. Alitropus Edwards, Sysconus Harger, and AEgathoa Dana may be mentioned as genera pointing toward a transition between the AEgide and Cymothoide, and it is evident that the latter family is made up of forms degraded by parasitism. They have thus exchanged the ambulatory legs of the AEgide for strietly ancorwl legs, for the most part in seren pairs, and have lost the natatory eilia of the pleopods. Their autennary organs are also much less perfect than in that family. All these modifications are in the line of the sedentary life of a parasite.

The interesting observations of Mr. J. F. Bullar have shown that in certain genera of the Cymothoidec (Cymothoa, Neroeila, Anilocra) a peculiar form of hermaphroditism occurs, the young at a certain stage of development being males with well developed testes and external organs, but possessing at the same time ovaries with the oviduet ending blindly. As development proceeds the male organs are lost by molting, the oviduet obtains an external opening, the incubatory pouch is developed, and the animal becomes a female. Mr. Bullar's statements provoked consiclerable discussion, but they have recently been verified by Mayer, who has, howerer, shown that self-fertilization does not occur.

Three genera of Cymothoidce are represented within our limits by as many speeies, and a fourth speeies, Cymothoa progustator Say* (Latrobe) may yet be found, being not a rare parasite in the month of the menhaden (Brevoortia menhaden Gill) in southern waters. The projeetion of the front of the head over the bases of the antennary organs, and the strongly hooked or ancoral legs are characteristic of the family, and the genera may be distinguished by means of the following table: Uropods $\left\{\begin{array}{l}\text { ciliated, eyes large conspicuous, } \\ \text { naked; body }\left\{\begin{array}{l}\text { symmetrical; posterior epimera elongated, } \\ \text { unsymmetrical; epimera short, }\end{array}\right.\end{array}\right.$

AEgathoa, p. 393 Nerocila, 1. 391 Livoneca, p. 394

\section{Nerocila Leach.}

Nerocila Leach, Dict. Sci. nat., tom. xii, p. 351, 1818.

Body oval; head small; eyes of moderate size; posterior thoracic segments and epimera angulated or spiniform, giving a sharply serrated or dentated outline to the thorax; first two "abdominal epimera" also spiniform; pleon of six distinet segments.

Onr species of Nerocila has the characters of the genus much less pronounced than some foreign ones, as the posterior epimera are nearly

\footnotetext{
*Jour. Acad. Nat. Sci. Phila., vol. i, p. 395, 1818.
} 
or quite concealed from above by the projecting angles of the segments, and the "abdominal epimera" are mostly concealed beneath the pleon. These organs are the much elongated inferior angles of the segments, which in allied genera, as AEgathoa, are short and not produced. In a lateral view they considerably resemble the posterior epimera, giving the appearance of two additional pairs. The specimen first described is smaller than others that have since been obtained.

Nerocila munda Harger.

Nerocila munda Harger, This Report, part 1, p. 571 (277), 1874; Proe. U. S. Nat. Mus., 1879, vol. ii, p. 161, 1879.

Verrill, This Report, part i, p. 459 (165), 1874.

Plate X, Fig. 65.

This species may be recognized among our Isopoda by the projecting posterior epimera, and the two pairs of spiniform "abdominal epimera" beneath the pleon.

The body is oval, twice as long as broad, smooth, polished, and moderately convex. The head is flattened, broader than long, narrowing anteriorly, broadly rounded or subtruncate in front, three-lobed behind, with the middle lobe largest. The eyes are black and consist of an irregularly rounded patch of small indistinct ocelli, and are visible both above and below. The antennulx are about as long as the head, and composed of eight segments, of which the first is short, the second is the longest, and the remaining six decrease pretty regularly in size to the last. The antennæ are a little longer and more slender than the antennula and have the first segment short, the second subglobose, the third, fourth, and fifth cylindrical, and a little larger than the segments of the flagellum, which are about five in number. The mandibular palpi are longer than any three segments of the antennx, and the first segment is large, the second elongate conical, the third shorter, cylindrical.

The first thoracic segment is much longer than the succeeding ones and adapted to the head in front. It is slightly produced at its lateral angles behind, or rather appears so from the union of the epimera, which really constitute the projecting angles to the segment. In the second, third, and fourth segments the posterior angles are.but little produced, and are equaled or slightly surpassed by the epimera, but in the last three segments the posterior angles are acutely produced much bejond the epimera of the corresponding segments, the angle of the sixth segment nearly attaining the end of the seventh epimeron. In a lateral view, only the last two epimera are decidediy aente, while those of the second and third segments are obtuse and rounded behind. Seen from below, the posterior angles of the epimera are acute throughont. The first pair of legs are slightly more robust than the second and third; the last four pairs are still more slender, the last pair longest, and the last two pairs armed with a few short spinules.

The pleon is shorter than the thorax and much narrower, though 
not suddenly so and tapers but little posteriorly; the telson is flattened, and regularly rounded behind. The "abdominal epimera" are acnte, the second smaller and more slender than the first, but their extension backward varies with the state of contraction of the pleon. The uroporls (pl. X, fig. $65 a$ ) surpass the telson, aud have the inner angle of the basal segment sharply produced. The rami are flattened; the exterial one twice the length of the basal segment, narrowly ovate or lanceolute, sometimes slightly eurved, and surpassing the telson by half its length. The inner ramus is narrowly oval, obliquely truneate behind and about three-fourths as long as the outer.

The length of the specimen figured, which was the one first described, is $15^{\mathrm{mm}}$, breadth $7^{\mathrm{mm}}$, but specimens measuring $25^{\mathrm{mm}}$ in length have since been collected; color brown or greenish, with two narrow dorsal bands of lighter color, most evident at the extrenities.

The original specimen was obtained on the dorsal fin of Ceratacanthus aurantiacus at Wood's Holl!, Vineyard Sound, in 1871, and two more specimens of larger size have since been obtained, also from Vineyard Sound!, Mass.

Igathoa Dana.

ZEgathoa Dana, Am. Jour. Sci., II, vol. xiv, p. 304, 1852.

Body elongate oval; pleon not suddenly narrower than the thorax; head large, subtriangular; eyes large; legs nearly alike throughout, with strong eurved dactyli ; epimera of moderate size or small; pleon long and large, composed of six distinet segments; pleopods not eili. ated; uropods more or less distinctly ciliated, rami subequal.

This genus is represented in our fauna by a species parasitic in the mouth of a squid. The large, granulated eyes remind one of AEga, and the ciliated uropods also indicate the approximation of this genus to the preceding family. The ciliation is, however, nearly rudimentary in our species, and is present, at least in the young, of other members of the Cymothoidec.

ÆEgathoa loliginea Harger.

Egathoa loliginea Harger, Am. Jour. Sci., III, vol. xv, p. 376, 1878; Proc. U. S. Nat. Sus., 1879, vol. ii, p. 161, 1879.

Plate X, Fig. 66.

The legs all armed with strong curred claws, the large conspicuous eyes and the slightly ciliated uropods serre to distinguish the present species from the other Išpoda of our coast.

Body elongate oval in outline, nearly four times as long as broad, slightly dilated near the posterior end. Head broadly rounded in front, subequally, but not deeply, trilobed behind. Eyes large, with evident facets, lateral, semi-hexagonal, visible from below, covering nearly half the area of the head above, projecting posteriorly beyond the middle 


\section{REPORT OF COMMISSIONER OF FISH AND FISHERIES.}

lobe of the head. Exteriorly they form about two-thirds of the lateral margin of the head. Their interior boundary is in the form of three sides of a hexagon, separated at their nearest points by a little more than the transverse diameter of the eye. The antenullæ are about as long as the head, composed of eight segments and separated at the base. The first segment is short and stont; the next two a little longer, but scarcely distinguishable from the following five flagellar segments, which decrease in size to the last. The antennæ are composed of ten seginents. They are more slender than the antennule, and surpass them by about two segments. The first two segments are broader than the following three, which are also somewhat larger than the five flagellar segments.

The first thoracic segment is shorter than the head, but mneh longer than any of the suceeeding segments, which to the sixth are of equal length, each about one-third shorter than the first. The seventh segment is about one-third shorter than the sixth. The fifth and sixth are broadest, each being abont one-third broader than the first. The epimera do not project behind the angles of the segments to which they are attached. The legs differ but little throughout. The first pair are shortest, and the first three pairs are somewhat stronger than the last four, which are armed with a few seattered short spinules. The serenth pair are the longest.

The pleon is a little longer than the seven thoracic segments. The fifth segment is broader behind than in front, and the last segment is as broad at the insertion of the uropods as the third segment, and is rounded behind. Anterior pleopods with the basal segment nearly square. The uropods are unlike on the opposite siles in the speeimen figured. The normal form is probably seen in the right uropod, which surpasses the telson by less than half the length of the onter ramus. This ramus is longer than the inner, narrow, with nearly parallel sides and is obliquely truncated at the tip. The inner ramus is somewhat diamond-shaped. The ciliation is nearly rudimentary and might be orerlooked. The basal segment is alike on the two sides and has the inner distal angle acute and but slightly produced.

Length $13^{\mathrm{mm}}$, breadth $3.6^{\mathrm{mm}}$; color in alcohol yellowish, with minute black specks most abundant on the pleon; eyes black, conspicuous.

The specimen was obtained June 1, 1S74, by Mr. S. F. Clark, at Savin Rock!, near New Haven, from the mouth of a squid (Loligo Pealii), whenoe the specific name. Two specimens "parasitic on joung mullet" are in the Yale College Museum, collected at Fort Macon!, N. C., by Dr. H. C. Yarrow, which appear to belong to this species, showing that it is not confined to the squid.

\section{Livoneca Leach.}

Livoneca Leach, Dict. Sci. nat., tome xii, p. 351, 1818.

Head small, projecting in front over the bases of the antennulæ, which, like the antenna, are short; legs all alike and armed with strong curved dactyli; body broad, oval, often obliquely distorted. 
This genus is represented by a singlo species, in which the body is of a broadly oval form and depressed. $\Lambda 11$ the legs aro short and armed with strongly curved dactyli, and, in the natural position, are closely appressed to the ventral surface, which, however, is more or less exposed below along the middle.

Livoneca ovalis White (Say).

Cymothoa ovalis Say, Jour. Acad. Nat. Sci. Phil., vol. i, p. 394, 1818.

Dekay, Zool. Now York, Crust., p. 48, 1844.

Lironeca oralis White, Cat. Crust. Brit. Mus., p. 109, 1847. (Lironeca).

Harger, 'This Report, part i, p. 572 (278), pl. vi, fig. 29, 1874; Proc. U. S.

Nat. Mus., 18\%9, vol. ii, p. 16:, $18 \% 9$.

\section{Plate XI, Fig. 67.}

The broadly oral, more or less distorted and unsymmetrical form of this Isopod serves to distinguish it from any other species yet recognized within our limits.

Body broad, oval, usually oblique, and not, as represented in part I of this report, pl. VI, fig. 29, with the sides of equal length. The legs, moreover, in that figure are in an unnatural position, as they are, during life, concealed beneath the body of the animal and appressed to the ventral surface, the first three pairs directed forwards and the last four pairs backward. The dorsal surface is moderately convex. The head is small, rounded in front, trilobed behind, the middle lobe much the larg. est, the two lateral lobes extending beyond the eyes, which are not conspicious, small and broadly separated. Antennulæ (pl. XI, fig. 67a) widely separated at the base, with the first segment short and stout; the second longer and somewhat tapering; the third about as long as the first. These peduneular segments are somewhat flattened. The flagellum is longer than the perluncle, tapering and five-jointed, curved backward in the natural position, each segment bearing a row of short blunt setre, near the distal end, on the inner curre. The antennæe (pl. XI, fig. $67 b$ ) are about as long as the antenmulie, with the first two segments short and stont, the next three more slender; flagellum three or four jointed, with the last segment imperfectly divided and tipped with a few short setæ. The maxillipeds are narrow, with the outer lamella partially united to the basal segment and the palpus tapering and twojointed, tipped with a few short enrved setr, at least in young indiriduals. The mandibles are pointed; their palpi (pl. XI, fig. $67 \mathrm{c}$ ) tapering from the base and composed of three segments of about equal length, the first subquadrate, the second tapering, the third nearly eylindrical.

The first thoracic segment is longest; the next three a little shorter and about equal; the fifth and sixth still shorter; the serenth shortest measured along the median line, which is usually a curved line except in joung specimens. The anterior margin of the first thoracic segment is adapted to the posterior margin of the head and presents three sinuses, the middle one largest, for the median lobe of the head, and two smaller ones for the ocular lobes. The posterior margin of this segment is strongly convex backward throughout. In the sueceeding segments 
this convexity rapidly diminishes so that the fourth has nearly a transverse margin and the last three segments become concave behind in an increasing degree. The epimera are narrow and obtusely pointed behind, and do not surpass the posterior angle of the segment to which they are attached except in the last two segments. The first pair of legs (pl. XI, fig. $67 d)$ are short and stout, the basal segment large but short; the next three segments short and with little motion on each other; the propodus stont and somewhat curved; the dactylus long, curved, and strong. The second and third pair of legs are much like the first, as are the four succeeding pairs, but somewhat larger and longer. The seventh pair (pl. XI, fig. $67 \mathrm{e}$ ) have the basal segment about twice as long as in the first pair, and the succeeding segments are also proportionally longer than in the first pair, except the dactylus, which is slightly weaker and not longer than in the first pair.

The pleon tapers rapidly at the sides; its first five segments are sub. equal in leugth; the last segment forms about half its length, and is flat and broadly rounded behind. Uropods (pl. XI, fig. 67f) surpassing the telson with the basal segment, about as long as the rami and but little produced at its inner angle; outer ramus linear oblong, rounded at the end; inner ramus shorter and broader, oblique at the tip.

Length $17-22^{\mathrm{mm}}$, breadth $10-12^{\mathrm{mm}}$. These animals when preserved in alcohol are of a leaden color, with the posterior margins lighter.

They are often parasitic on the blue-fish (Pomatomus saltatrix Gill). The details figured on plate XI are from small specimens collected on young blue-fish at New Haven!, by Mr. F. S. Smith. Other localities are Thimble Islands!, Long Island Sonnd; Vineyard Sound!, Fish Commission 1871, one specimen among scup (Stenotomus argyrops Gill). A specimen was sent to the Museum in 1878, collected by Dr. T. H. Bean, from the gill of Micropogon undulatus canght at Norfolk!, Va., July 9, 1878.

Specimens cxamined.

\begin{tabular}{|c|c|c|c|c|c|c|}
\hline$\frac{\stackrel{\dot{E}}{E}}{\stackrel{\Xi}{E}}$ & Locality. & Parasitic on- & $\begin{array}{l}\text { When col. } \\
\text { lected. }\end{array}$ & Received from- & 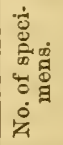 & $\begin{array}{l}\text { Dry. } \\
\text { Alc. }\end{array}$ \\
\hline & Norfolk, Va.. & Micropogon ..... & July 9,1878 & T. H. Bean .... & 1 & Alc. \\
\hline 2071 & New Haven................. & Blue-fish........ & .............. & F.S. Smith ......... & 15 & Alc. \\
\hline 2072 & Vineyard Sound ............. & .... do ........... & -1871 & U. S. Fish Com.... & 1 & Alc. \\
\hline 2073 & 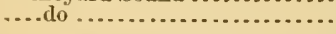 & Scnp............... & Ang. 17, 1871 & . do & 1 & Alc. \\
\hline 2074 & Vineyard Sound & Blue-fish & Scpt $2,187 i$ & $\dddot{\mathrm{U}} \mathrm{\textrm {S }}$ Figh Com & ${ }_{i}$ & Alc. \\
\hline 2076 & .................. & ................. & .............. & F. H. Bradley..... & 1 & Alc. \\
\hline
\end{tabular}

\section{XII.-ANTHURID AE.}

Body elongate, cylindrical; mouth suctorial; legs ambulatory and prehensile, the first pair enlarged; first pair of pleopods thickened and crustaceous, protecting the following pairs; uropods articulated at the sides of the last segment, standing in a more or less vertical position and forming with the telson a sort of eup or flower at the end of the body. 
This family is represented within our limits by three species belonging to as many genera, which, in addition to the characters given above, agree further in the following particulars: The boly is elongated and vermiform, often more than ten times as long as broad, and of nearly uniform size throughout. The head and thoracic segments are all distinetly separated from each other, and the head and last thoracic segmeut are shorter than the intervening segments, which are subequal. Both pairs of antennæ are approximate at their bases, and the lower pair or true antenne are short, not greatly surpassing the head in length. These organs have the basal segment short, the second segment flattened internally and adapted to its fellow of the opposite side, while abore and externally it is exeavated for the basal segment of the antennulæ. The mandibles are palpigerous, and the mouth parts are fitted for piereing and for suction.

In the first pair of legs the first, second, and penultimate segments aro enlarged and thickened; the two intervening segments, merus and carpus, are short; the dactylus forms a curved finger tipped with a stont spine and eapable of complete flexion on the robust propodus. In one or two of the succeeding pairs of legs the propodus may be slightly enlarged. The first three pairs of legs have the carpus, or antepenultimate segment, triangular, and their basal segments are directed strongly backward. In the last four pairs the carpus may be short, but is not triangular, and always distinetly separates the merus from the propodus; they are so articulated to the body that their basal segments are directed forward. The first three pairs of legs are articulated to the anterior part of the segment to which they belong, the next three near the middle of the corresponding segments, and the last pair near the posterior margin of the last segment.

The pleon is short, with the segments more or less consolidated, and the pleopods are of the normal number and form. The "opereulum" is not formed as in the Idoteidae and Arcturidae of the uropods, but is nothing more than the enlarged and thickened first pair of pleopods, the greater part of it being formed of the external lamella, while the uropods have an entirely different and peculiar structure. They are biramons, and consist on each side of a more or less elongated, flattened, basal segment, so articulated as to lie alongside the telson, and bearing at the apex a terminal plate, the inner ramus, in the same plane with itself, while, on its upper side near the base, stands a more or less perpendicular, oval plate, the outer ramus. The telson is directed obliquely downward, and, with the uropods, forms a ciliated cup-like or flower-like termination of the cylindrical body, whence the name Anthura, from the Greek üvios, a flower, and ov̀ $\dot{\alpha}$, a tail.

The strueture of the mouth in this family has been investigated by Prof. J. C. Schiölte, to whose original papers in the Naturhistorisk Tidsskrift I lave not had access. The paper on Anthura is translated and partly condensed in the Annals and Magazine of Natural History, 
where that author states that "next the Cymothoida, though as a type of a separate family, the genus Anthura must be placed."

The species of this family may be at once recognized by the peculiar cup-like termination of the body. This cup or "flower" is formed by the telson below, and the uropods at the sides and above; the outer rami of the latter organs being placed nearly vertically, and approaching each other on the median line above, where, however, the "flower" is more or less imperfect. Our three genera may be distinguished as follows: First five segments of pleon consolidated abore, Anthura (p. 104); segments of pleon distinct, antennæ and antennulæ subequal, Paranthura (p. 108); segments of pleon distinct, antennulæ greatly enlarged in the male, Ptilanthura (p. 111).

\section{Anthura Leach.}

Anthura Leach, Ed. Encyc., vol. vii, p. "404" (Am. ed., p. 243), "1813-'14."

Antennula and antennæ short, subequal; thoracic segments not separated by constrictions; pleon with the five anterior segments consolidated above and resembling the last thoracic segment.

Our species of Anthura appears to agree in all generic characters with A. gracilis Leach upon which the genus was founded. In A. polita, however, the consolidated portion of the pleon is seen at the lower part of the sides to be composed of five consolidated segments, and bears the normal number of pairs of pleoporls, while Bate and Westwood* say that " the four anterior segments are soldered elosely together" in A. gracilis, and that "the pleopoda consist of, at least, four pairs of oval plates, strongly ciliated, on each side of the ventral surface of the basal segments of the tail." They had not, however, fresh speeimens of the species, which is evidently closely related to ours.

The inenbatory ponch of the females in the genns is confined to the third, fourth, and fifth segments, and is composed of three pairs of lamellæ, which overlap from behind forward, while the anterior margins of the first pair are united to the anterior part of the third segment.

\section{Anthura polita Stimpson.}

? Anthura gracilis Dekay, Zool. New York, Crust., p. 44, pl. ix, fig. 34, 1844 (not of Montagu and Leach).

Anthura polita Stimpson, Proc. Acad. Nat. Sci. Phil., vol. vii, p. 393, 1856.

Harger, Proc. U. S. Nat. Mus., 1879, vol. ii, p. 162, 1879.

Anthura brunnea Harger, This Report, part i, p. 572 (278), 1874.

Verrill, This Report, part i, p. 426 (132), 1874.

\section{Plate XI, Figs. 68 and 69.}

This species is distingnished among its allies on our coast by the nearly complete union of the basal segments of the pleon, which have together the appearance of an eighth thoracic segment. The cup or "flower" at tha end of the body serves to distinguish it from other Isopoda. 
The body is smooth, shining and flattened above and broadly keeled in the males below. The head is a little broader than long, deeply excavated on each side of the front for the bases of the antenuula, and produced at the sides. The eyes are small and lateral but distinet, and are placed on the outer side of the anterior prolongations of the head, about on a line with the bases of the antennula. They are too indistinet in the figure, and the eye was even omitted on the right side by the engraver. The anteumula (pl. XI, fig. (is a) consist of a tapering threejointed peduncle and a very short flagellum. The first pedunenlar segment is the largest, and is flattened above and on the inner side; the second segment is smaller, cylindrical, and provided with a comb of hairlike setæ along its onter side; the third is smaller and shorter than the second; the flagellum consists of a single very small segment, with indications of a rudimentary second segment at the end, where it is also tipped with setæ. The antennæ (pl. XI, fig. 6Sb) consist of a five-jointed peduncle, and a short flagellum much like that of the antennulæ. The basal segment of the peduncle is short; the second segment is the largest and is of peculiar shape, being excavated on the onter side to adapt it to the antennula, which lies in the groove thus formed, while the segment is bent upward and inward, and exposes a slender triangular area with the point backward, between, and on a lerel with, the antennulæ; the next three segments are sub-cylindrical and diminish in size, and are followed by one or two small flagellar segments tipped with setæ.

The maxillipeds (pl. XI, fig. 69a) are thick and strong, and are composed of a basal quadrate segment, a little longer than broad, with its proximal external angle elided for the short, sub-triangular external lamella, and bearing two segments representing the palpus. Of these segments the first is but little smaller than the basal segment and is sub-quadrate, tapering a little at the sides beyoud the middle. The terminal segment is straight at its articulation with the preceding, and nearly so along the inner side, then rounded in the remainder of the ontline. The segments of the palpus are finely ciliated along their margins, except along the external margin of the first segment, where the ciliation nearly disappears; they are also provided with coarse setæ, a few of which occur on the maxilliped, near the outer distal angle. The inner maxilla (pl. XI. figs, $69 b$ and $b^{\prime}$ ) is rather robust, and terminated by a strong tooth or spine, below which, on the inner side, is a row of smaller curved teeth. The mandibles are terminated by a horny tooth, below which is a serrulated lobe; the mandibular palpus is robust; the second segment much the longest and provided with stont setæ; the last segment with a comb of rather short setæ. The maxillipeds are of much firmer texture than the other parts of the mouth.

The first thoracic segment is the longest, and is closely adapted to the head behind so as to allow but little motion. The second segment is shorter but somewhat broader than the first, and is rather freely 
articulated with it, and still more freely with the third; it is carinated below, but its articulations are much less free than in the next genus. The third, fourth and fifth segments are each about the length of the seeond; the sixth and seventh are progressively shorter. The first pair of legs (pl. XI, fig. $68 \mathrm{c}$ ) are quite robust and have but little freedom of motion, being directed forward under the head and hardly capable of further lateral extension than is shown in the figure of the animal. The basis and ischinm are large and articulated so as to form a curve, bringing the legs forward; the merus is short; the earpus is triangular and extends along the side of the thickened propodus for about half its length, projecting like a tooth at the end; the propodus is orate, much thickened and armed with a tooth near the middle of the palmar margin, along which it is ciliated, as is also the carpus; the dactylus is short and stout and tipped with a slender, enrved, chitinous claw abont as long as the dactylus itself. The figure (pl. XI, fig. $68 c$ ) represents the inner surface of the leg, the merus being much less conspienous on the outer side. The second and third pairs of legs are nearly alike and much more slender than the first pair. One of the third pair is represented on plate XI, fig. $68 d$. In both these pairs of legs the carpus is small and triangular and wedged in between the merus and propodus, which meet above; the merus is a little larger in the second than in the third pair, and in both pairs it is provided with a few setre at the upper distal angle and along the opposite or palmar side, where the carpus is also armed with setæ; the dactylus bears a few very short setx. The remaining pairs of legs are rather more slender than the second and third, and the merus is separated from the propodus above by the carpus, which is, however, short. These legs are somewhat hairy, like the preceding pairs.

The anterior part of the pleon (pl. XI, fig. $68 g$ ), consisting of the first five segments consoliclated, appears much like an eighth thoracie segment a little longer than the seventh; traces of the sutures between the segments can bo seen at the sides. The last segment is distinetly artienlated, a little elevated dorsally, where it is also somewhat hairy; at the lower part of the sides it is covered by a slightly projecting lobe of the preceding segment, which extends orer the proximal part of the basal segment of the uropods. Distally the terminal segment is depressed at a steep angle, and is in the form of a plate, ovate and ciliated at and near the tip, where it is obtuse; the sides are nearly parallel, and it is surpassed by the uropods, which consist, on each side, of a large basal segment, earinated on the onter side and toothed at the articulation with the outer ramus, obliquely truneated at the end, where it bears a short, obtusely-triangular, eiliated, inner ramus, or lamella, in the same plane as the basal segment. The outer ramus, or lamella, forms nearly a right angle with the basal segment, and stands upon its superior onter margin. This ramus is elongate reniform in outline, being notehed below for the tooth on the basal segment, and is 
ciliated along its free superior margin. The first pair of pleopods (pl. XI, fig. 68e) are composed on each side of a short, quadrate basal segment supporting two rami, of which the outer is, like the basal segment, of firm texture, and acts as an operculum; in shape it is semioval, with the inner margin nearly straight, and is eiliated distally, and along the outer margin. The inner ramus is much smaller than the onter and of delicate texture, and, in the natural position, is covered and concealed by the outer ramus; it is slender, with nearly parallel sides, rounded at the tip, and not ciliated. In the males the second pair of pleopods (pl. XI, fig. $68 f$ ) bears, near the middle of the inner margin of the inner ramus, a slender stylet, slightly surpassing the lamella to which it is attached.

The lamellæ forming the incubatory pouch of the females are of considerable antero-posterior dimensions, and the posterior widely overlap the anterior ones, while the anterior border of the first lamella is united with the third thoracic segment, to which the lamella belongs.

'Length $15-18^{\mathrm{mm}}$; breadth $1.8-2 \mathrm{~mm}$. The color is brownish abore, mottled with yellowish or honey color, lighter underneath.

This species was described as new by the present author in the first part of this report under the name $A$. brunnea, but there appears to be no sufficient reason for regarding it as distinct from Dr. Stimpson's $A$. polita. It is apparently closely related to $A$. gracilis Leach, although sufficiently distinct according to Bate and Westwood's* description and figures. Those authors, however, seem to have had but rery poor and imperfect material on which to base their work. They figure and describe the telson and uropods as truncated and crenulated, and Montagu, $\dagger$ in his original deseription of the species, says that "the body is terminated by five large caudal appendages truncated at their ends."

Kröyer's $\ddagger$ deseriptions and figures of $A$. carinata approach much more closely to the present species. His figure of the antennula considerably resembles ours, but in his description he gires as the relative lengths of the four segments composing it $11,4,3,5$. In our species the last or flagellar segment is much the shortest, as may be seen by the figure, plate XI, fig. $68 a$. He further speaks of the telson as crenulated, while it is entire in A. polita, and his figure (Voy. en Seand., pl. 27, fig. $3 n^{\prime}$ ) shows no tooth-like projection or angle on the basal segment of the uropods, as seen in a lateral view, and the corresponding margin of the outer or superior plate is destitute of the notch shown in the lateral view of these organs on plate XI, fig. $68 g$. The inner ramus or lamella of the first pair of pleopods is also figured as much larger and more expanded distally than in our species, for which see plate XI, fig. $68 e$. Unfortunately I hare had no European specimens for comparison.

* Brit. Sess. Crust., vol. ii, p. 160, 1868.

†Trans. Linn. Soc., vol. ix, p. 103, pl. v, f. 6, 1808.

$\ddagger$ Naturhist. Tidssk., II, B. ii, p. 402, and Voj. en Scand., Crust., pl. xxvii, fig. $3 a-0$, 1849. 
This species was described by Dr. Stimpson from specimens taken at Norfolk, Va., and has since been collected by Professors Smith and Verrill at Great Egg Harbor!, N. J., in $1 \frac{1}{2}$ fathoms shells and mud; by the U. S. Fish Commission in Long Island Sound!, especially at Noank Harbor!, among eel-grass (Zostera marina) and mud; off Block Island! in 17 to $19 \frac{1}{2}$ fathoms sand, mud, and stones; at Vineyard Sound!, at low water and in sand, and in 1878 at Gloucester!, Mass., in mud and among algæ.

Specimens examined.

\begin{tabular}{|c|c|c|c|c|c|c|c|}
\hline $\begin{array}{l}\text { 㟔 } \\
\text { 苜 } \\
\text { 学 }\end{array}$ & Locality. & 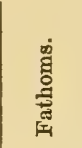 & Bottom. & $\begin{array}{l}\text { When col- } \\
\text { lected. }\end{array}$ & Receivedfrom- & 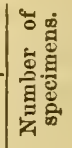 & $\begin{array}{l}\text { Dry. } \\
\text { Alo. }\end{array}$ \\
\hline $\begin{array}{l}2077 \\
2078 \\
2079 \\
2080\end{array}$ & 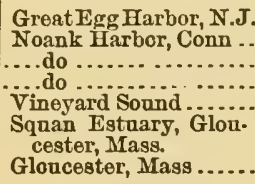 & 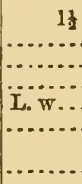 & 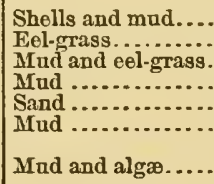 & $\begin{array}{l}\text { Apr. }-1871 \\
\text { Aug. } 28,1874 \\
\text { Aug. } 29,1874 \\
\text { Aug. } 28,1874 \\
\text { Sept. } 8,1871 \\
--, 1878 \\
-\quad-, 1878\end{array}$ & 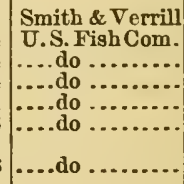 & $\begin{array}{l}2 \\
2 \\
2 \\
2 \\
2\end{array}$ & $\begin{array}{l}\text { Alo. } \\
\text { Alo. } \\
\text { Alo. } \\
\text { Alo. } \\
\text { Alo. } \\
\text { Alo. } \\
\text { Alo. }\end{array}$ \\
\hline
\end{tabular}

Paranthura Bate and Westwood.

Paranthura Bate and Westwood, Brit. Sess. Crust., vol. ii, p. 163, 1866.

Pleon articulated, composed of six segments; thorax deeply constricted at each end of the second segment; antennulæ and antennæ subequal; palpus of maxillipeds three-jointer; inner maxillæ acicular.

The first character given above is the only one given by Bate and Westwood, who, however, mention that the pleon bears the normal number of pleopods; a character that would not distinguish our species from the other genera. The distinctly articulated flagellum of the antennulæ is provided with a partial whorl of bristles, which, however, forms only the most rudimentary approach toward the structure of those organs in the males of the following genus. The segmentation of the pleon is indistinct in the dorsal region, but is apparent at the sides when seen from above, and the pleon does not at all resemble an additional thoracic segment as in Anthura. Both pairs of antennæe are provided in our species with a distinctly articulated flagellum, and are of nearly equal length.

Paranthura brachiata Harger (Stimpson).

Anthura brachiata Stimpson, Mar. Inv. G. Manan, p. 43, 1853.

Verrill, Am. Jour. Sci., III, vol. v, p. 101, 1873; ibid., vol. vii, pp. 42, 411, 502, 1874 ; Proc. Am. Assoc., 1873, pp. 350, 357, 1874; This Report, part i, p. 511 (217), 1874.

Whiteaves, Am. Jour. Sci., III, vol. vii, p. 213, 1874 ; Further Deep-sea

Dredging, Gulf of St. Lawrence, p. 15, "1874."

Harger, This Report, part i, p. 573 (279), 1874.

Smith and Harger, Trans. Conn. Acad., vol. iii, p. 16, 1874.

Paranthura brachiata Harger, Proc. U. S. Nat. Mus., 1879, vol. ii, p. 162, 1879. 
Plate XI, Fig. 70.

The deep constrictions, by which the second thoracic segment is separated from the first and third, serve to distinguish this species from the allied forms on our coast, and the "flower" at the end of the pleon distiuguishes it from other Isopoda.

Borly moniliform, with evident segments; head narrower than, and about half as long as, the first thoracic segment, flattened and quadrate above, with a groove behind a raised anterior border, wedge-shaped below, deeply emarginate on each side of the projecting front above for the bases of the antennuli; eyes Iateral, not conspicuous, extending behind the emarginations. Antenuulæ (pl. XI, fig. $70 a$ ) with the first segment large but longer than broad, flattened abore; second and third segments cylindrical; flagellum of twelve or more segments in adult specimens, with the first segment short, second twice as long and the longest segment of the flagellum, which tapers from the second segment and bears on the distal end of each segment an imperfect whorl of hairs. The antennæ (pl. XI, fig. $70 \mathrm{~b}$ ) slightly surpass the antennulæ. They have the first segment short; the second flattened on the inner side, where it is usually in contact with its fellow of the opposite side, and excavated on the outer side above to aceommodate the basal segment of the antennulæ; the third segment is short; the fourth and fifth longer and cylindrical. The flagellum consists of about twelve segments, tapers from the base, and is somervat hairy. Both the antennæ and antennulæ are a little less dereloped and have one or two less segments in the females. The maxillipeds (pl. XI, fig. $70 \mathrm{c}$ ) are elongated, with a short, oval external lamella, and a two-jointed palpus. The large basal segment of the maxilliped projects on the inner side nearly to the end of the first segment of the palpus. The palpus has its segments of about equal length and provided with a few seattered bristles. The inner maxilla (pl. XI, figs. $70 d$ and $d^{\prime}$ ) are evident at the tip in an under view of the head; they are elongate and acicular, and minutely and sharply retro-serrate toward the tip. The three-jointed palpus of the mandibles is also conspicuous below; all three of its segments are short, and the last, which lies ordinarily between the bases of the antennæ, is flattened, oval, and provided with the usual comb of setæ.

The thorax is somewhat flattened above, carinate anteriorly below; and has the last segment much the shortest. The first segment is wider than the head and about twice its length, and is more closely united with it than are any of the thoracic segments with each other; it is strongly carinate below, especially on its anterior part, where the carina ends in a prominent tubercle; a much more slender carina bounds the flattened dorsal portion laterally. The second segment is separated from the first by a deep constriction, and is articulated so as to allow considerable motion, especially in a vertical plane; its antero-lateral angles are prominent in the form of low, rounded tubereles, and be- 
tween them are two less evident tubercles on the front margin of the segment; the dorsal surface tapers behind, and is bounded laterally by carina; below, the segment is wedge-shaped, but not carinated; belind, it is separated from the third segment by a constriction not quite as pronounced as that in front. The third segment presents two rather more evident median tubercles in front on the dorsal surface, which is defined laterally by carinæ, fading away at about the middle of the segment; below, it is wedge-sluaped and carinate in the males, but membranons along the median line in the females, as are the remaining segments more widely in that sex. In the males they are hard and ehitinous throughout, rounded and scarcely wedge-shaped. The fourth segment is slightly longer than any of the others, and bears, near the anterior end of its dorsal surface, an oval depression with slight elongated elerations at each side. A similar structure oceurs on the fifth and sixth segments, which are of decreasing length. The seventh is much the shortest thoracic segment, not being longer on the median line than the head; it is somewhat produced laterally.

The first pair of legs (pl. XI, fig. $70 e$ ) are not as stout as in Anthura polita, and are more flexible; the carpus is the shortest segment, and is triangular, broader than long; the preceding segment, or merus, shows but little in an external view, but is more eviclent in an inner view, as shown in the figure, and is much broader than long; the propodus is much swollen proximally on its anterior or upper side; immediately in front of the end of the carpus it bears a stout tooth; the dactylus is strong, and tipped with a curved claw. In the second and third pairs of legs the carpus is triangular, but in the posterior pairs it is more elongated so as to distinetly separate the merus from the propodus.

The pleon is short, the telson triangular, acute at the apex. Uropods with the basal segment strongly carinate exterually, terminal plate acutely triangular, proximal superior plate oval, curved and attached by its side, nearly meeting its fellow of the opposite side above. First pair of pleopods (pl. XI, fig. $70 f$ ) with the external ramus semi-oval; internal ramus less firm in texture, ligulate, ciliated distally. Second pair of pleopods in the males (pl. XI, fig. $70 \mathrm{~g}$ ) furnished with a sleuder stylet articulated at about the middle of the inner, posterior, lamella, und extending beyond its end. Both the lamellæ are crossed by a transrerse suture just beyond their middle, at the point where the stylet is ittached to the imner one.

Length $28^{\mathrm{mm}}$; breadth $2.2^{\mathrm{mm}}$; females about one-third smaller. The yolor is usually light yellowish brown, or sometimes somewhat darker, but not as pronounced as in the other members of the family, and nearly che same throughont.

From $P$. norvegica G. O. Sars* our species is distinguished by the eyes, which, though inconspicnous, are present. It lacks the tubercle de- 
scribed and figured by Heller on the head of $P$. arctica, $t$ and the flagellar segments of both pairs of antenna distinguish it from $P$. costana Bate and Westwood.t

This species was dredged by Dr. Stimpson "on a shelly and somewhat muddy bottom in twenty fathoms off the northern point of Duck Island," Bay of Fmuly. It is rare sonth of Cape Cod, but was taken in Vineyard Sound! by the Fish Commission in 1871; also on St. George's Bank!, in 110 fathoms, mnd and sand; Gulf of Maine!, down to 115 fathoms; Bay of Fundy!, down to 80 fathoms on muddy, shelly, and sandy bottoms; and off Nova Scotia!, 59 fathoms, pebbles, sand and rocks, and at other localities as detailed below. It was dredged by Mr. Whiteaves in 200 fathoms in the Gulf of Saint Lawrence, between Anticosti and the mainland of Gaspé.

Specimens examined.

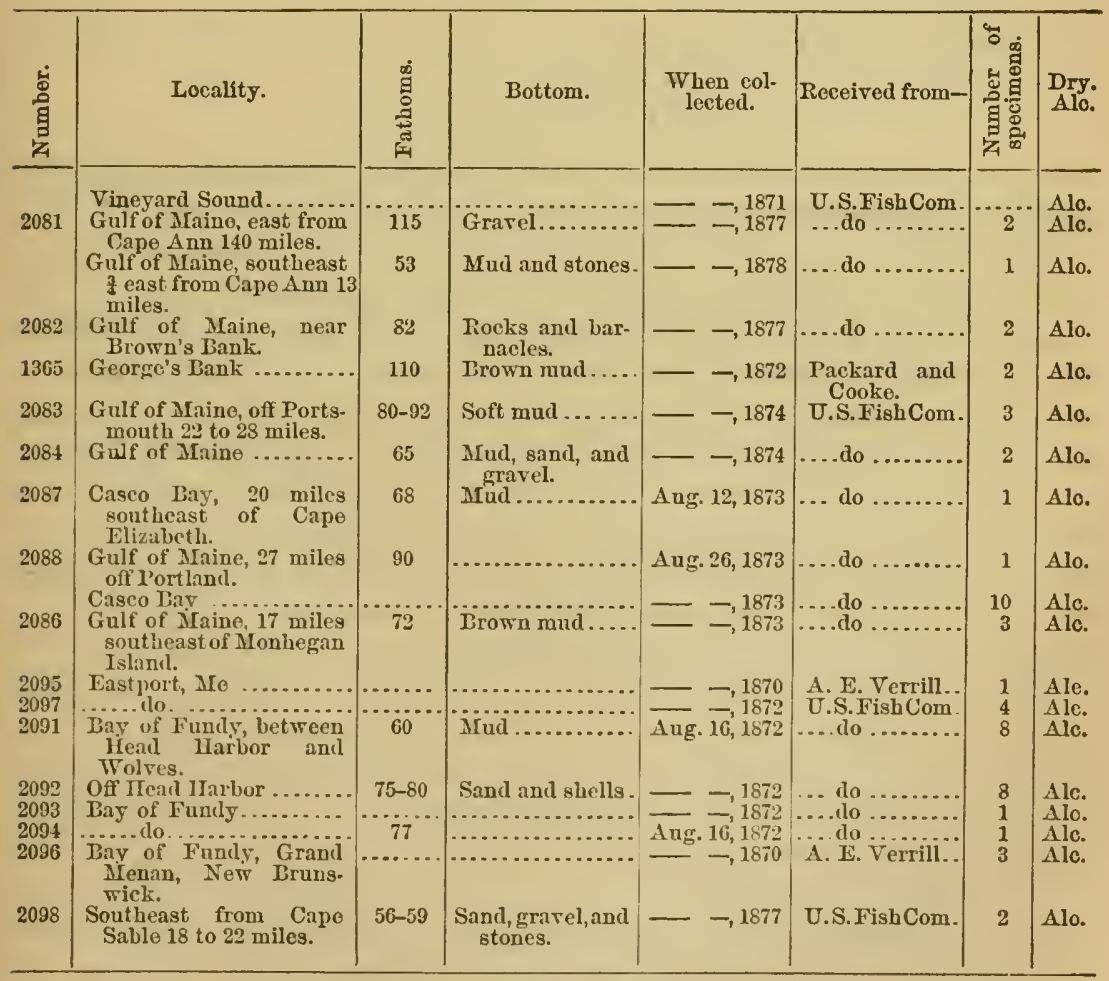

\section{Ptilanthura Harger.}

Ptilanthura Harger, Am. Jour. Sci., III, vol. xv, p. 376, 1878.

Antennulæ with the flagellum remarkably developed in the male, multiarticulate; second and succeeding antennular segments provided 
with an incomplete, very dense whorl of fine slender hairs; pleon seg. mented, elongated; palpus of maxillipeds one-jointed.

The most important character of this genus is doubtless found in the structure of the autennulæ in the male sex. In the females the antennulæe are small, and the flagellum consists of a few slender rapidly tapering segments. They thus bear considerable resemblance to young specimens of Anthura polita, and being collected with them, were at first mistaken for them. They are distinguished by the larger and more conspicuous eyes, and by the more elongated and distinctly segmented pleon. In the presence of eyes our species differs from a form described by G. O. Sars, Paranthura tenuis, from near Stavanger, Norway, in which the males have a well-developed, eight-jointed and densely hairy or setiferous flagellum on the antennulæ.

Ptllanthura tenuis Harger.

Ptilanthura tenuis Harger, Am. Jour. Sci., III, vol. xv, p. 377, 1878; Proc. U.S. Nat. Mus., 1879, vol. ii, p. 162, 1879.

Plates XI and XII, FIGs. 71-74.

Males of this species are at once recognized by the greatly developed antennulæ, resembling miniature bottle-brushes; females may be distinguished from the young of the other species by the conspicuous ejes; they are much smaller than the adults of the other species.

The body is smooth, flattened above, narrow at the middle, broadest at the base of the pleon. Head broader than the first thoracic segment and nearly as long, on the median line; longer than broad, narrowing to a point in front and much less acutely behind. The eyes are prominent, black, sitnated within the margin of the head and visible both above and below. The antennulie in the males (pl. XII, fig. 74a), when reflexed, attain the third thoracic segment; the first segment is large, but not longer than the second; the third is shorter than the second and followed by a short, subtriangular segment, which must be regarded as the first segment of the flagellum, although resembling the last peduncular segment much more than it does the succeeding or second flagellar segment; this segment is small at its base, but expands rapidly above and below and on the side which is next the body in the ordinary reflexed position of the antennula, aud on these sides it bears, at its distal end, a fine and dense fringe of long slender hairs, which attain, when appressed, about the fifth following segment. Similar segments, to the number, in some specimens, of eighteen or twenty follow, forming an organ resembling a mimute bottle brush or plume, whence the generic name. On one side, however, of the organ, which corresponds nearly with the outer or anterior side, according as the antemula is more or less reflexed, the whorl of hairs is interrupted. In the females (pl. XI, fig. 73) the antennulæ are shorter than the antennæ, with a short flagellum consisting of a small basal segment and a minute terminal one tipped with a few setæ. The antennæ (pl. XII, fig. $74 b$ ) are short, 
differing little in the sexes, hardly surpassing the peduncle of the antennulx in the males, with a short three or four jointed flagellum bearing a few hairs near the tip. Tho maxillipeds (pl. XI, fig. $71 b$ ) have a quadrate basal segment, somewhat emarginate externally for the subtriangular external lamella, and bearing a single suboval terminal segment, or palpus, somewhat truncate and ciliated at the tip. The inner maxilla (pl. XI, fig. 71c) are five-toothed, one tooth being strong and terminal and the other four lateral. The mandibles bear a singlejointed palpus.

The thoracie segments are subequal in length except the last, which is but little over half as long as the others, though broader behind than any of them. They are slightly narrower than the head and margined laterally with a somewhat raised ridge. The third, fourth, and fifth have an elongate oval depression on the median line near the anterior margin. The first pair of legs (pl. XI, fig. 72) have the segments well separated, the carpus nearly equilaterally triangular, the propodus moderately thickened, and the dactylus strong and tipped with a stout claw; the carpus and propodus are bristly on their palmar margins. The remaining pairs of legs are slender and nearly equal in size.

The pleon is about as long to the tip as the last three thoracic segments. The first fire segments are consolidated along the dorsum, but distinct at the sides. Each segment rises into a low broad tubercle on each side of the median line. The last segment is about as long as the preceding five, and is elongate-ovate, and obtusely pointed behind. The basal plate of the uroporls is about half as long as the telson; the terminal or inner lamella is triangular-orate, and about equals the telson. The proximal or superior lamella is narrowly semi-ovate, with an emargination on the upper side near the tip. The first pair of pleopods (pl. XI, fig. 71d) are shorter than the abdomen, and have the onter plate semi-obovate and the inner shorter, with nearly parallel sides. The second pair of pleopods (pI. XI, fig. 71e) bear, in the males, a slender straight stylet, articulated below the middle of the inner lamella and slightly surpassing it. The outer lamella is imperfectly articulated near the middle.

Length $11^{\mathrm{nm}}$; breadth $0.9^{\mathrm{mm}}$; females about one-third smaller; color brownish and more or less mottled abore, lighter beneath, margined with translncent at the sides, extending on the sides of the head as far as the eres.

This species is rare on the eoast. It has been taken by the United States Fish Commission, on muddy bottom, in Noank Harbor, Long Island Sound!; off' Watch Hill!, R. I., in 18 fathoms, sand; and off Block Island!, in 17 to $19 \frac{1}{2}$ fathoms, sand, mud, and stones; at Waquoit, Vineyard Sound!, in sand, at low water, September S, 1871; in Casco Bay!, sand and mud, from 9 fathoms, in 1873, and by Prof. A. E. Verrill, at Grand Menan, in the Bay of Fundy! in 1870.

It is nearly related to and doubtless congenerie with Paranthura 
tenuis G. O. Sars, ${ }^{*}$ but is at once distinguished by the presence of eyes, from which character, as distinetive, the name $P$.oculat $u$ night be applied to our species if a new trivial name should be thought necessary.

Specimens examined.

\begin{tabular}{|c|c|c|c|c|c|c|c|c|}
\hline \multirow{2}{*}{ 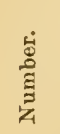 } & \multirow{2}{*}{ Locality. } & \multirow{2}{*}{ 离 } & \multirow{2}{*}{ Bottom. } & \multirow{2}{*}{$\begin{array}{l}\text { When col. } \\
\text { lected. }\end{array}$} & \multirow{2}{*}{ Receivedfrom- } & \multicolumn{2}{|c|}{$\begin{array}{l}\text { Speci- } \\
\text { mens. }\end{array}$} & \multirow{2}{*}{$\begin{array}{l}\text { Dry. } \\
\text { Alc. }\end{array}$} \\
\hline & & & & & & No. & Sex. & \\
\hline $\begin{array}{l}2099 \\
2104\end{array}$ & Noank Harbor, Conn & & Mnd.... & --1874 & U.S. Fish Com & 1 & 8 & Alc. \\
\hline 2100 & off watch Hill, R. I & 18 & Sand.............. & $\overline{\text { July }} \overline{31}, 1874$ & $\begin{array}{l}\text { a.do } \\
\text {....do }\end{array}$ & 1 & o & $\begin{array}{l}\text { Alc. } \\
\text { Alc. }\end{array}$ \\
\hline 2105 & Off Block Island .... & $17-19 \frac{1}{2}$ & Sand, mud, and &,- 1874 & ....do & 1 & ф & Alo. \\
\hline 2103 & $\begin{array}{l}\text { Vineyard Sound, } \\
\text { Mass. }\end{array}$ & L. $w$. & Sand.. & Sept. 8,1871 & .....do . & 1 & $q$ & Alc. \\
\hline 2101 & Casco Bas, Me ...... & & Mud. & July 16,1873 & .... do & 1 & $\sigma^{\circ}$ & Alc. \\
\hline $\begin{array}{l}2102 \\
2106\end{array}$ & Bdo do Find $\mathrm{Grand}$ & 9 & Sand and mnd .. & Ang. 4, 1873 & . do & 1 & $\sigma_{0}^{\circ}$ & Alc. \\
\hline & ifenan. & & & & & & & \\
\hline
\end{tabular}

\section{XIII.-GNATHIID $A$.}

Thorax with only five pairs of legs of the normal form in the adults, and apparently consisting of only five segments; antennulie and antenna short, with evident distinetion into peduncle and flagellum; month organs suetorial in the larval state, more or less aborted in the adult; pleon with its segments distinct, bearing the normal number of pleopods; uropods inserted at the sides of the base of the last segment, biramous and resembling the pleopods but of firmer texture.

This family is represented on our coast by a number of forms, all of which, however, appear to be referable to a single species, in which, contrary to what is ordinarily observed in the order, a considerable transformation occurs, especially in the males, after the young leave the incubatory ponch, and before they reach the adult form. The sexes are very unlike at maturity, but in both the thorax may be seen, by a little inspection, to consist in reality of seven segments, of which the first is united with the head, but separated from it by a sutural line near its posterior margin, while the serenth is small and resembles the segments of the pleon, which appears as if consisting of seren segments. The last thoracie segment does not bear a pair of legs. The head is large in the adult male and armed with a powerful pair of eurved jaws projecting strongly forward and eurved upward. The antennula are short and widely separated at base. The antennæ are inserted nearly below them.

The five pairs of pediform legs are ambulatory and nearly aliko throughout; the propodal segments are somewhat elongate, and the dactyli weak. All the thoracic segments except the first are distinct in the male, and all are distinet in the larval forms, but the fourth and fifth 
(third and fourth free segments) are indistinctly separated in the adult females.

The pleon is much alike in both sexes and the young, and consists of six distinct segments, each of which bears a pair of appendages. The first five pairs of these appendages, or pleopods, are carried beneath the pleon and subserve the purposes of respiration, while they are also used in swimming. They consist of a short basal segment supporting two rami, ciliated at the tip in the young. The uropods are directed backward and are of firmer texture than the pleopods. They are ciliated near the tip.

Only a single speeies has yet been recognized within our limits, and the male, female, and young will be described under the specific name.

The striking sexual differences in this family have caused much confusion, the males having been referred to one genus (Anceus), and the females to another (Praniza), and eren these genera have been referred to different tribes or subfamilies. The true relationship of these forms, long ago suspected by Leach, was first made known by M. Hesse,* who, however, seems not to have stated it very clearly and perhaps did not correetly apprehend it at first. His deseriptious, however, of the females of Anceus apply to what had previonsly been regarded as the female of Praniza, although he says in the same paper that Praniza is only the larval state of Anceus, which is true only of the young, or larral forms, or the then supposed males of Praniza. This family has been further investigated by Bate, Westwood, and Dohru, to whose writings the reader is referred. It may be here remarked that Bate and Westwood in their account of the structure of Anceus, in the second volume of the British Sessile-Eyed Crustaeea, appear to have orerlooked the last thoracic segment, and suppose that either the first or second segment must be wanting. Dohru calls attention to the rudimentary (or embryonic) condition of the seventh thoracic segment as the one missing to complete the normal number, but describes and figmrest as "untere" and "obere Mundextremitiit" ("verwandeltes erstes" and "zweites Gnathopoden Paar") what I regard as the maxillipeds and first pair of thoracie legs, or, according to Spence Bate's terminology, which Dohrn seems to have misapprehended, the maxillipeds and the first pair of gnathopods. The second pair of gnathopods are perliform as usual in the Isopoda, and are the first of the five pairs of legs. Of the five pairs of pereiopods normally present, only four are dereloped in the Gnathiidae. The family is thus remarkable in the order both for the transformations undergone in its development, and for the retention after all of an embryonic feature.

Having discarded the names Anceus and Praniza for reasons given below, I hare also rejected the family name Anceidce and substituted for it a name, suggested by Bate and Westwood and derived from that

${ }^{*}$ Ann. Sci. nat., IV, tom. ix, p. 106, 1858.

tZeit. Wiss. Zool., xx, taf. vii, figures 24 and 25. 
of the typical genus. The name Anceidce should perhaps be restored in caso Risso's species should not prove to be congeneric with Gnathia termitoides Leach, Cancer maxillaris Montagu.*

Gnathia Leach.

Gnathia Leach, Ed. Encyc., vol. vii, p. “402” (Am. ed., p. 240), "1813-14."

Praniza Leach, MSS.

Anceus Risso, Crust. de Nice, p. 51, 1816.

Head very large and quadrate in the male, smaller and subtriangular in the female; first pair of legs operculiform in the male, subpediform in the female; pleon much narrower than the thoracic segments, with nearly parallel sides, and a sharply triaugular telson.

The name Anceus Risso, which has been used by modern writers for this genus, ought, according to all rules of priority, to give way to Anathia Leach, as acknowledged by Bate and Westwood, $\dagger$ who, howerer, hesitated to restore the name on account of Kirby's coleopterous genus Gnathium. While the undoubted priority of the name is a sufficient reason for its re-establishment, it may be worth while to add that Gnathia was not restricted by Dr. Leach to either sex alone, as that author had the sagacity to "suspect that Oniscus coeruleatus Montagu [Praniza coeruleata Desm.] was the female" of Gnathia, and, as far as I am aware, did not publish a generic name for the Praniza-form, although the name Praniza was used by him as a manuscript name, and as sneh appears to have been published by Latreille in the Encyelopédie Methodique, which I have not been able to consult.

\section{Gnathia cerina Harger (Stimpson).}

Praniza cerina Stimpson. Mar. Inr. G. Manan, p. 42, pl. iii, fig. 31, 1853.

Packard, Mem. Bost. Soc. Nat. Hist., vol. i, p. 296, 1867.

Verrill, Am. Jour Sci., III, vol. vi, p. 439, 1873; vol. vii, pp. 38, 41, 411, 502, 1874; Proc. Am. Assoc., 1873, pp. 350, 354, 358, 362, 1874.

Anceus americanus, Stimpson, Mar. Inv. G. Manan, p. 42, 1853.

Gnathia cerina Harger, Proc. U. S. Nat. Mus., 1879, vol. ii, p. 162, 1879.

Plate XII, Figs. 75-79.

It will be convenient first to describe the male of this species and then the female and larval forms. The powerful and prominent jaws in front of the large quadrate head of the males of this small Isopod serve to distinguish it from any other on our coast.

The shape of the body is well described by Dr. Stimpson, as "regularly rectangular, abruptly narrowed at the commencement of the abdomen, which has the appearance of another very small rectangle set into the first, and of only one-third its width." It is somewhat bristly hairy, and much tuberculated and roughened above, especially on the lateral portions of the head and on the anterior thoracic segments. The head is broader than long, depressed medially in front and produced into a rounded lobe between the projecting upturned jaws. The eyes are small 
and placed well forward at the sides of the head. The antennula (pl XII, fig. $76 a$ ) are shorter than the head and slender, sparingly lairy, with a short, few-jointed flagellum. The antennse (pI. XII, fig. $76 b$ ) are also slencler, with the first segment apparently composed of two united; the second segment short; the third and fourth longer, nearly cylindrical and followed by a slender few-jointerl flagellum. The jaws (pl. XII, fig. $76 \mathrm{c}$ ) are elongite and turned upward at the apex, irregularly and bluntly toothed near the base within, and somewhat carinate on the outer side near the middle, the carina ending rather suddenly in a tooth-like process of the jaw as seen from above. The under surface of the head is deeply and broadly grooved longitudinally, and this groove is covered by what appear to be the transformed first pair of thoracie legs (pl. XI, fig. $7(6 d)$. They are in the form of a semi-oval plate on each side, attached near the base of the external side and strongly couvex and ciliated on the imner side, where they overlap. This plate is truncated at the apex, where it bears a sinall oval lamella; on the surface of the large plate aro three large, oval, semi-transparent areas. Within these plates is another pair of organs, consisting of a large basal segment and an articulated series of four flattened eiliated segments. These may be regarded as the maxillipeds, with a four-jointed palpus.

The first thoracic segment is indicated above only by a faint sutural line near the posterior margin of the large head. It is followed by five rery distinet segments, of which the first two are perhaps most distinet, short, and strongly tuberculated, especially along their posterior margins. The third free segment is broader than the second, square at the sides, with two broad lateral elevations. The fourth free segment is somewhat rounded in front, with its chitinous integument apparently not ealcified along the median line. The fifth free segment is narrower than the preceding and produced at the sides around the small last thoracic segment and the base of the pleon. The legs are nearly alike throughout, somemhat hairy and spiny.

The pleon is slightily dilated at the middle, with the angles of the segments saiient. The last segment is acutely triangular, ciliate behind, surpassed by the uropods, which are also ciliated with a few bristles; both rami are slender, the inner a little broader than the outer. The pleoporls (pl. XII, fig. $78 e$ ) consist of two slender elongate lamellie, the inner longer than the outer, attached to a basal segment and not ciliated in the adults of our species.

Leugth $4.4^{\mathrm{mm}}$; breadth $1.3^{\mathrm{mm}}$; color dirty yellowish brown above, lighter below. This form is Anceus americanus Stimpson.

The adult female (pl. XII, fig. 77) differs from the male principally in the following characters: The body is smooth and tapers behind and before, but is inuch swollen medially, where the segmentation becomes obscure, and the thoracic region seems converted into a sack for the reception of the eggs, plainly to be seen through the transparent integument. The head is comparatively small and subtriangular, emarginate 
in front. The eves are placed farther back, and the large conspicuous jaws are wanting. Under the head, the first pair of legs (pl. XII, fig. 78 a) are slender, three-jointed with a minute terminal segment, and lie upon a delicate membranous plate on each side; within these are a pair of organs resembling what I have regarded as the maxillipeds of the male.

The first two free thoracie segments are short and eurved somewhat around the head; the next two segments are much enlarged and nearly coalescent, and the fifth free segment is nearly similar in form to that of the males. The last thoracie segment is short and small and, as in the male, resembles a segment of the pleon.

The pleon (pl. XII, fig. $78 \mathrm{c}$ ) differs little from that of the male, but the angles of the segments are less salient.

Length $3-4^{\mathrm{mm}}$; breadth $1.5^{\mathrm{mm}}$. Color "pale yellowish or waxen." Dr. Stimpson was "inclined to consider" this form as the female of Praniza cerina.

The larval forms bear a much greater resemblance to the female than to the male but are more slender than either, the thorax being, in the smaller specimens, but little broader than the pleon. The head is broad: with large prominent eyes, and is distinet from the first thoracie segment, its posterior margin being truneated. The antennulæ have a short basal segment to the flagellum, which is followed by an elongate eylindrical segment forming about half the leugth of the flagellum, but bearing at its end a few short segments. The mouth organs project beyond the head, giving it an acnte outline, and are evidently formerl for piercing and suction. The large jaws of the adult males are, of course, wanting. The maxillipeds are slender and elongated.

The first pair of thoracic legs (pl. XII, fig, 78b) are elongate, with the normal number of segments, a triangular carpus, and a strong curred dactylus, reminding one of the legs of the Cymothoidcc. The first thoraeie segment is small and short and well separated from the following segments. The next two segments are quite distinct in all the forms, but usually the fourth, fifth, and sixth segments are united much as in the adult female. These forms appear to be the young females, and were described by Dr. Stimpson under the name of Praniza cerina; more rarely, however, specimens are found in which all the thoracic segments are distinet and somewhat resemble those of the adult male, but with their peculiarities less marked (pl. XII, fig. 79).

The pleon resembles that of the adults, but is not suddenly much narrower than the thorax. The pleopods as well as the uropods are ciliated at the tip (pl. XII, fig. $78 d$ ).

Both these forms of young were taken from the body of a sculpin in the Bay of Fundy in 1872, and, when fresh, their bodies were bright red. In alcohol they fade to a waxy yellow.

Adult males of this speeies greatly resemble Anceus elongatus Kröyer, 
but his Praniza Reinhardi differs in its proportions of the antennary segments from $G$. cerina.

This species was leseribed by Dr. Stimpson from females "lrediged on gravelly and coralline bottoms in 20-30 fathoms in the Hake Bay," and males "dredged on a sandy bottom in 10 fathoms off" Cheney's Head," Grand Menan, in the Bay of Fundy. It has been collected by the U. S. Fish Commission in Massachusetts Bay!, off Salem, 22-50 fathoms, gravel and soft mud; Gulf of Maine!, at several loealities; Casco Bay !, 50 fathoms; Bay of Fundy !, in many localities, 10 to 60 fathoms, rocks, stones, and mud, and young specimens have been taken adhering to codfish and the sculpin. It was dredged by Mr. J. F. Whiteaves in the Gulf of St. Lawrence!, in 220 fathoms, mud. Further details in regard to localities are given in the subjoined table.

Specimens examined.

\begin{tabular}{|c|c|c|c|c|c|c|c|c|}
\hline \multirow{2}{*}{ 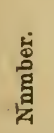 } & \multirow{2}{*}{ Locality. } & \multirow{2}{*}{ 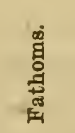 } & \multirow{2}{*}{ Bottom. } & \multirow{2}{*}{$\begin{array}{l}\text { When col- } \\
\text { locted. }\end{array}$} & \multirow{2}{*}{ Received from- } & \multicolumn{2}{|c|}{$\begin{array}{l}\text { Speci- } \\
\text { mens. }\end{array}$} & \multirow{2}{*}{$\begin{array}{l}\text { Dry. } \\
\text { Alo. }\end{array}$} \\
\hline & & & & & & No. & Sex. & \\
\hline & $\begin{array}{l}\text { Massachusetts Bay, } 3 \\
\text { miles S. E. Nahant. }\end{array}$ & & Mud.... & Aug. 31,1879 & J. H. Enoerton. & 3 & q & Alo. \\
\hline 2108 & $\begin{array}{l}\text { Massachusetts Bay, } \\
\text { off Salem E. S. E. } \\
9 \text { to } 11 \text { miles. }\end{array}$ & 22 & Gravel, stones. &,-- 1877 & U. S. Fish Com. & 3 & & Alc. \\
\hline 2109 & $\begin{array}{l}\text { Massachnsetts Bay, } \\
\text { off Salem E. S. E. } \\
8 \text { to } 9 \text { miles. }\end{array}$ & 33 & Mnd ........ &,-- 1877 & : _...do ........... & 1 & $q$ & Alc. \\
\hline 2121 & $\begin{array}{l}\text { Massachnsetts Bay, } \\
\text { off Salem E. S. E. } \\
6 \text { to } 7 \text { miles. }\end{array}$ & $25-26$ & Gravel, stones. &,-- 1877 & ....do ... & 1 & ㅇ & Alo. \\
\hline \multirow[t]{2}{*}{2110} & $\begin{array}{l}\text { Massachusetts Bay, } \\
\text { off Salem E. S. E. }\end{array}$ & $45-50$ & Mnd . &,-- 1877 & ....do .. & 12 & 69 & Alo. \\
\hline & $\begin{array}{l}11 \text { to } 13 \text { miles. } \\
\text { Gulf of Maine, S. E. } \\
\text { S. from Cape Ann, } \\
6 \text { to } 7 \text { miles. }\end{array}$ & $54-60$ & Sand, mud..... &,-- 1878 & ....do . & 12 & రீ\%5. & Alc. \\
\hline 2107 & $\begin{array}{l}\text { Gulf of Maine be- } \\
\text { tween Cape Ann and } \\
\text { Isle of Shoals. }\end{array}$ & $27-36$ & ....do .......... &,-- 1874 & .....do ......... & 1 & q & Alo. \\
\hline 2111 & Casco Bay .............. & 50 & & Ang. 6, 1873 & $\ldots$ do $:$....... & 2 & 9 & Alc. \\
\hline 2112 & 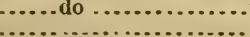 & & & 二 - 1873 & 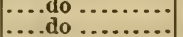 & 10 & $0^{\circ} 8$ & $\begin{array}{l}\text { Alc. } \\
\text { Alo. }\end{array}$ \\
\hline 2115 & Eastport, iro.. & $10-20$ & Rocky............ & 二 -, 1872 & ... do ... & 3 & 87 & Alo. \\
\hline 2117 & & $\cdots \cdots$ & . & 二-,1872 & A. $\mathrm{do}$. verrili ....... & $\begin{array}{l}\mathbf{3} \\
\mathbf{3}\end{array}$ & 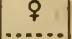 & $\begin{array}{l}\text { Alc. } \\
\text { Alc. }\end{array}$ \\
\hline 2114 & Bay of Fundy ... & $25-30$ & on sculpin, \&e. & 二 二, 1872 & U.S. Fish Com & 12 & y. & Alc. \\
\hline 2118 & a....do do & $20-30$ & & $=-, 1872$ & a.do & 5 & 80 & Alc. \\
\hline 2119 & $\begin{array}{l}\text { Bay of Fnndy, off } \\
\text { Head Harbor. }\end{array}$ & 40 & &,-- 1872 & .....do. & 6 & סீ? & Alc. \\
\hline 2122 & $\begin{array}{l}\text { Bay of Fnndy } \ldots . . . . . \\
\text { Off Sable Island ...... }\end{array}$ & $\begin{array}{c}60 \\
160\end{array}$ & On $I$ & $\begin{array}{l}1870-72 \\
-1878\end{array}$ & $\begin{array}{l}\text { A. E. Ver } \\
\text { U.S. Fish }\end{array}$ & $\begin{array}{r}00 \\
4\end{array}$ & $\delta$ & $\begin{array}{l}\text { Alc. } \\
\text { Alc. }\end{array}$ \\
\hline 2120 & Gulf of SaintLawrenco & 220 & Mnd .. & & J. F.Whiteaves & 1 & J. & Alc. \\
\hline
\end{tabular}

\section{XIV.-TANAIDAE.}

Respiration cephalothoracic, taking place in a cavity beneath the walls of the united head and first thoracic segment; eyes, when present, articulated; antennular flagellum single; first pair of legs enlarged and more or less perfectly chelate; pleopods natatory, ciliated, not branchial ; uropods, terete, terminal, with at least one jointed ramus. 
This family differs widely from all the other Isopoda, and indeed from all the sessile-eyed Crustacea, in the structure of the respiratory organs, and in the fact that the eyes, when present, are articulated with the head, or stalked, though without any proper pedicel.

I have seen species of only two genera, Leptochelia Dana and Tanais Audouin and Edwards, from within our limits. These genera are, by some authors, united under the name Tanais, but there seems to be ample reasons for separating them. While they agree in many eharacters, they differ widely from Apseudes Leach, which should probably be regarded as belonging to a different family not represented on our coast, and is accordingly not included in the above diagnosis.

Our representatives of the Tanaidce may be further characterized as follows: The body is subeylindrical and elongated, from four or five to at least eight times as long as broad. The head and first thoracic segment are covered by the large cephalothoracic shield, which tapers somewhat in front, and is dilated behind. Its postero-lateral regions are occupied on each side by the branchial cavity, opening behind by a vertical slit, and in front by a nearly horizontal orifice. During life a lash-like organ can be seen through the body wall, in constant vibration, propelling a stream of water from behind forward throngh the cavity. The eyes, when present, are distinctly articulated with the head, and in the males are generally larger and more coarsely granulated than in the females. They are absent in one of our species, as in the one mentioned by Willemoes-Suhm from 1,400 fathoms in the Atlantic Ocean, off the North American coast, obtained by the Challenger expedition. They are described as indistinct in other foreign species. The antennule are inserted close together immediately below the vertex of the head and between the eyes. They are robust at base, and in the males may be elongated, but in the females are short, with only three or four segments and a minute rudiment of a flagellum. In neither sex have they any trace of the secondary flagellum seen in Apseudes. The anteunie are more slender than the antennulæ, and inserted almost directly beneath them. They are five-jointed, with the first and second segments short, the third larger and longer, the fourth and fifth slender and eylindrical, and, like the antennulæ, with indieations of a flagellum. The antennæ, like the antennulre, are tipped with bristles and bear a few scattered similar bristles on their segments.

The mouth organs are aborted in the males, at least in the genus Leptochelia, but in the females the mouth is protected below by a well-developed pair of maxillipeds, of which the basal segments meet at an angle forming a keel on the under surface of the head. The palpi of the maxillipeds are four-jointed, and armed with strong eilia ; the last segment is strongly flexed on the penultimate. The immer maxilla are spiny, and have the outer lobe reflexed and bearing elongated cilia at the tip. The mandibles are strong, destitute of palpi, and armed with one or two dentigerous lamellæ at the apex and a strong molar process. 
The first pair of legs are robust, and in the males may be large and much elongated; they are in both sexes of our species powerful organs of prehension, being strongly chelate. Like the remaining pairs of legs, they have onls five movable segments, unless an articulater spine at the extremity of the fifth segmeut is to be regarded as the true dactylus. On the other hand, the basal segment in many specimens presents indieations of a short segment at its distal end, as if really consisting of tho unied basis and ischinm. If this latter supposition be the true one, the hand of the first pair of legs is formed, as might be expected, of the propodus and the dactylus; the propodus is thickened and provided with a digital process stronger than the eurved dactylus, which closes against it; the digital process bears toward the tip a few stout, bristly setæ. These legs are attached to the under side of the united head and first thoracic segment below the branchial cavity, and are directed forward. They are capable of but little lateral motion, and are nearly in contact below, especially toward their bases, which cover and partly conceal the organs of the mouth and the bases of the antennæ. The second pair of legs are very slender in comparison with the first, and are more slender than those that follow. Their basal segments are flattened, somewhat elongated, and usually bent with the convexity outward, in adaptation to the basal segments of the first pair of legs, which they partly embrace. The last three pairs of legs have their basal segments swollen.

The pleon consists, in our species, of five or six segments, and bears three or fire pairs of strongly eiliated pleopods of the ordinary form, and fitted for swimming, and also a pair of uropods, consisting of a large basal segment bearing one or two rami. This ramus, or the inner one when there are two, is articulated and composed, in our species, of from two to six segments. The outer ramus may also consist of more than one segment. Like the antennulie and antennx, the uropods are provided with setre, which are often elongate.

In the young the seventh pair of legs are not developed, and, according to Miiller, the pleopods are likewise wanting and the uropods have less than the adult number of segments.

This family has been the subject of special research by Fritz Müller, Spence Bate, Dohrn, and others, to whose writings reference may be had for further description of their anatomy and development. Their proper place aunong the Crustacea cannot be regarded as settled, though the opinion of Fritz Niiller that they represent an ancestral type of Isopoda is probably the best offered as yet. According to Dohrn, they present in their derelopment affinities with Asellus, Ligia, and Cuma. Gegenbaur associates his Tanaida with the Podophthatma rather than the Edriophthalma.

Our species of this family are sharply divided into two genera, for which I hare, after some hesitation, adoped the names Tanais Aud. and Edw. and Leptochelia Dana. I hare not been able to see Audouin and Edwards' Résumé d'Entomologie, in which the genus Tanais is said to 
have been established, withont description, in 1829. In the Précis d'Entomologie, by the same authors, is a figure (pl. xxix, fig. 1), apparently the same as that in the Résumé, which is there called Tanais de Costa. Latreille,* in 1831, characterized the genus, basing it upon Gam. marus Dulongii Aud., figured by Savigny. Westwood, $†$ in 1832, proposed for the same species the name Anisochcirus, without, however, mentioning any characters. In 1836, Templeton $\ddagger$ described and figured, with evident care and accuracy, a species of this family under the name Zeuxo Westwoodiana. This species has, according to his figure, six segments in the pleon. Edwards, in his general work, Histoire naturelle des Crustacés, figures and describes Tanais Cavolinii (tome iii, p. 141, pl. 31, fig. 6), and refers the figure in the Précis d'Entomologie to that species. In 1843, Rathke $\S$ described and figured Crossurus vittatus as a new genus and species allied to Apseudes and Tanais, bnt there do not seem to be any characters of importance to separate it from T. Cavolinii Edw., and, indeed, Bate and Westwood are inclined to regard them as identical species. If, however, T. Dulongii be regarded as the type of the genus, there appears to be nothing but the clothing of the basal segments of the pleon to separate the two genera, and this character seems of no more than specific value, since $T$. Du longii is described by Bate and Westwood as possessing the pecnliar "branchial appendages" at the base of the fifth pair of legs. These appendages are doubtless incubatory sacs, similar to those of $T$. vittatus.

For the second genus I have hitherto used the name Paratanais Dana, on the ground that Leptochelia of the same author, although having priority, was founded upon the characteristics of the male sex. The type-species, however, of this genus, $L$. minuta, possesses all the characters of Paratanais that could occur in the male. Leptochelia Edwoardsii Dana, Tanais Edwardsii Kröyer, moreover, belongs to the same genus, and I have adopted the name for both sexes.

The minute species, by which this family is represented on our coast, may be readily recognized by the proportionately large and strong chelate first pair of legs articulated to the united head and first thoracic segment. The two genera are distinguished by the number of segments in the pleon, which are five, with three pairs of pleopods in Tanais (p. 122), and six, with five pairs of pleopods in Leptochelia (p. 126).

Tanais Audouin and Edwards.

Tanais Audouin and Edwards, "Résumé (not Précis) d'Ent., p. 182 (without description, 1829), pl. xxix, fig. 1" (B. \& W.); Précis d'Entomol., p.46, pl. xxix, fig. 1.

Edwards, Hist. nat. des Crust., tom. iii, p. 141, 1840.

Crossurus Rathke, Fauna Norwegens, p. 35, 1843.

Antennulæe and antennæe simple ; mandibles without palpi ; pleon com. posed of five segments bearing three pairs of ciliated pleopods below, 
and a pair of simple uropods behind; eggs incubated in saes attached near the bases of the fifth pair of legs of the females.

This genus is distinguished from the next by the structure of the pleon and the uropods as given above, and the females are, when carrying eggs or young, distinguished from all the other Isopoda by the wartlike, or sac-like, appendages of the fifth thoracic segment. Usually a small wart-like appendage is visible on each side of the inferior surfice of the thorax just within the bases of the fifth pair of legs, but the size of these organs varies greatly, and in some speeimens they become distended with eggs, extended lengthwise with the body and more or less coalescent, so as to form the large, bilobed incubatory ponch, as figured by Rathke. This pouch is, however, attached only to the fifth segment.

The presence of a peenliar appendage to the fifth pair of legs in this genus has been noted by various authors. Bate and Westwood figure, in the seeond volume of the British Sessile-Eyed Crustacea, page 122, a leg of the fifth pair with the attached pouch, which they "regard as a branchial sae similar to those existing in the Amphipoda, and consequently affording a proof of the nearer relationship of Tanais with that order than is possessed by any other isopodous animal." They remark further that "this appendage is wanting in some specimens, and its variable existence is probably a character of specifie distinetion in the group." Those authors have not, however, separated T. vittatus into two species on this charaeter. Stebbing* mentions a specimen with eggs "as deseribed by Rathke." Maedonald $\dagger$ figures a female with an ineubatory pouch, which he briefly describes as "a membranous expansion or saccule under the thorax."

Rathke's original description is as follows: "Beide Exemplare, die ich untersuchen konnte, waren Weibchen und trugen Eier unter dem Thorax. Diese aber, die iibrigens verhiiltnissmässig ziemlich gross waren, lagen nieht, wie bei Idothea, Ligia und vielen andem Isopoden, in einer zum Theil aus Schuppen bestehende Brüthöle eingeschlossen, sondern bildeten zwei länglichovale, dicht neben einander liegende und an der Oberfläche nur wenig unebene Massen von ziemlich beträchtlicher Grösse. Jede von ihnen war zusammengesetzt aus den Eiern und einer durch. siehtigen eiweissartigen Substanz, die um jene herumgegossen war, sie wie ein Kitt zusammen hielt, und sie zugleich anch an die Bauchseite des Leibes befestigte. Es zeigten demnach jene Massen ganz dieselbe Zusammensetzung, wie die sogennanten Eiertrauben der Cyclopiden, Lernæaden und Branchiopoden." Rathke, having had only two speeimens, does not appear to have perceived the attachment of these masses at the bases of the fifth pair of legs, and of course had no opportunity to see them in various stages of development. A speeimen belonging to this genus and measuring 17 millimeters in length was obtained at Ker-

* Ann. Mag. Nat. Hist., IV, xvii, p. 78, 1876.

†Trans. Linn. Soc., II, Zool., vol. i, p. 69, pl. xv, fig. 1, 1875. 
guelen Island by Willemoes-Suhm,* who describes the saes attached to the fifth thoracic segment and attaining, as the young develop, a diameter of three to four millimeters.

Tanais vittatus Lilljeborg (Rathke).

Crossurus vittatus Rathke, Fauna Norwegens, p. 39, pl. 1, figs. 1-7, 1843.

Tanais tomentosus Krö̈yer, Naturhist. Tidssk., B. iv, 1. 183, 1842; ibid., II, B. ii, p. 41:, 1847; Voy. en Scand., Crust., pl. xxvii, figs. 2 a-q, "1849."

Lilljeborg, Öfvers. Vet.-Akad. Förh., Arg., viii, p. 23, 1851.

Meinert, Crust. Isop. Amph. Dec. Daniæ. p. 86, "1877."

Tanais hirticaudatus Bate, Rep. Brit. Assoc., 1860, p. 224, 1861.

Tanais vittatus Lilljeborg, Bidrag Känn. Crust. Tanaid., p. 29, 1865.

Bate and Westwood, Brit. Sess. Crust., vol. il, p. $125,1866$.

Stebbing, Trans. Devon. Assoc., 1874, p. (7), and 1879, p. (6); Ann. Mag.

Nat. Hist., IV, vol. xvii, p. 78, 1876.

Verrill, Am. Jour. Sci., III, vol. x, p. 38, 1875.

Macdonald, Trans. Liun. Soc., II, Zool., vol. i, p. 67-70, pl. xv, 1875.

Harger, Proc. U. S. Nat. Mus., 1879, vol. ii, p. 162, 1879.

Plate XIII, Figs. 81, 82.

This species is at once recognized among our Isopods by the pleon, which is beset with bristly hairs at the sides, and crossed by two rows of similar hairs near the posterior margins of its first two segments.

The body, though small, is rather robust, the length being about fire times the breadth, which is greatest at the first free, in reality the second, thoracic segment. The head and united first thoracic segment is short, not longer than broad. The eyes are distinctly articulated and much less in diameter than the bases of the antennulie. 'The antemula are shorter than the head and first thoracic segment, and are composed of three segments, of which the first is longer than the other two together, while the second and third are of about equal length; the third segment is terminated by one or two rudimentary segments, surmonited by a tuft of straight bristly setæ. Similar setæe arise from the terminal portions of the two preceding segments. The antenne are as long as the antennulie, but more slender, and consist of a five-jointed peduncle, somewhat setose like the antenunlæ, and terminated by a rudimentary flagellnm heset with setre. The basal plates of the maxillipeds are ciliated exterually, and meet each other on the median line so as to form a keel narrowing backwards; distally they become thicker and bear a four-jointed palpus, of which the second and third segments are dilated internally and ciliated, and the fourth is spatulate and ciliated at its extremity. The inner maxille have one of the lobes of the usual form and position, and armed with short, enrved spines at the tip, while the other is bent backward and bears several elongated cilia at the tip, and by its constant motion urges a stream of water through the branchial cavity.

The first pair of legs are much enlarged and extend, in their natural position, beyond the head, and the "hand" is orlinarily directed nearly downward. The digital process of the proporlus bears a broad lobe on its inner side, and an acute tooth at its extremity; at the side of the lobe 
is a row of setro; the dactylus is strong, with an obtuso tooth on its inner margin. In the second pair of legs the dactşlus is rather robust and tapers strongly. In the succeeding pairs of legs the dactyli become enrved, and, in the posterior pairs, hooked and armed with a comb of slender teeth, while the three preceding segments are also armed with slemler teeth or spines at their distal ends. The constrictions between the thoracic segments are well marked, giviug the body a somerwat moniliform appearance. In breeding females, a pair of warts, or sacs of greater or less size are found attached to the under surface of the fifth tholacic segment, aud containing eggs or young, according to their stage of development. These sacs often, if not usually, coalesce more or less perfectly before maturity.

The first three segments of the pleon are not narrower than the last thoracic segment, and are strongly margined, or tufted, at the sides with plumose hairs. These hairs are continued in two transverse rows, one upon the first and another on the second segment near their posterior margins, across the back of the pleon. This character is only imperfectly shown in the figure, where the transverse rows of hairs should have been more strongly indicated. The last two segments of the pleon are suddenly narrower than the first three. The last is much longer than the fourth and bears a short tooth at each side near the base. This segment may be composed of two nnited. The three pairs of pleopods are nearly alike (pI. XIII, fig. 82 ), and consist of a basal segment bearing two semi-oval lamella, which, as well as the basal segment, are strongly ciliated. The uropods are scarcely longer than the last two segments of the pleon, and the basal segment is comparatively small; the second segment is nearly as long as the first, the third about half as long as the second and tipped with setæ, with which the first two segments are also provided.

Length $5.5^{\mathrm{mm}}$; breadth $1.1^{\mathrm{mm}}$; color brown, mottled with lighter abore; beneath, nearly white.

This species occurred on piles and among algæ and eel-grass at Noank!, Conn., in the summer of 1874, along with Leptochelia algicola, but in much less abundance. It was described by Rathke from Molde, on the west coast of Norway, and inhabits also the British Isles, and while the present article was going through the press I received, through the kindness of Rer. T. R. R. Stebbiug, specimens from Torquay!, England, which confirm my previous determination of our species as identical with the European form. It has been found by J. D. Macdonald "in the excavated wood of piers, in compauy with Limnoria and Chelura terebrans." It is doubtfully identified by Bate and Westwood with a Mediterranean species, T. Cavolinii Edw. On the authority of Lilljeborg I have regarded it as identical with Tanais tomentosus Kröyer, although differing in the number and proportion of the segments of the pleon, as described and figured by that author. Kröyer's specimens were from Yresund, Denmark. 
Ieptochelia Dana.

Leptochelia Dana, Am. Jour. Sci., II, vol. viii, p. 425, 1849; U. S. Expl. Exped., Crust., P. 800, 1853 .

Paratanais Dana, Am. Jour. Sci., II, vol. xiv, p. 306, 1852; U. S. Expl. Exped., Crust., p. 798, 1853.

Antennula and antenna simple; mandibles without palpi; pleon composed of six segments, bearing five pairs of ciliated pleoporls below, and a pair of biramons uropods behind; incubatory pouch of the females of the normal form.

The genus Leptochelia was constituted by Professor Dana for a form which Fritz Miiller has since shown to be the male of Paratanais Dana, and although so far as I know the name has not hitherto been used for any but the male forms, I see no reason why it should not be adopted instead of the later name Paratanais. I have therefore adopted it for the four speeies lately describer, from our coast. Dr. Stimpson's Tanais filum undoubtedly belongs to the same genus, making five species within our limits, only four of which I have seen. The species that I have examined may be further characterized as follows: The body is of nearly uniform size thronghout. The antennulie are directed forward and have a large basal segment, in contact with its fellow of the opposite side at its origin, and composing about half the length of the organ in the females; but in the males this segment, though absolutely much larger than in the females, may not form more than about a third of the total length of the antennula, which is nine to twelve jointed and terminated by a well developed flagellum. The antenna differ but little in the sexes, and are five-jointed. The organs of the mouth are abortive in the males, and the oral region is covered below by a pair of subtriangular plates, perhaps the rudiments of the maxillipeds. The second thoracic segment is shorter than those that follow it; the fifth and sixth are the longest, and the seventh is shorter than the sixth.

The pleon consists of six distinct segments, subequal in length or with the last somewhat longer than the others. These segments are smooth above, and the first five bear ou their under surface each a pair of pleopods, much like those of Tanais (pl. XIII, fig. \$2), but not ciliated on the basal segment. The last segment bears a pair of uroporls, which consist of a large basal segment bearing two terete rami. Of these the onter ramus is shorter and smaller than the inner, and may consist of a single segment so small and short as to be easily overlooked; the inner ramus is larger and longer, and composed, in our species, of from two to six segments. The number of these segments appears to be of value as a specific character, but not perfectly constant.

In the females the incubatory pouch is formed, as in the order generally, by four pairs of lamellie attached to the bases of the second, third, fourth, and fifth pairs of legs. 
Leptochelia algicola Harger.

Leptochelic Eduardsii Bate and Westwood, Brit. Sess. Crust., vol. ii, p. 134, 1868 (Tanais Edwardsii Kröyer?).

Tanais filum Harger, 'This Report, part i, p. 573 [279], 1874 (non Stimpson).

Verrill, This Report, part i, 1. 331 (87), 1874.

Paratanais algicola Harger, Am. Jour. Sci., I1I, vol. xv, p. 377, 1878.

Leptochelia algicola Harger, Proc. U. S. Nat. Mus., 1879, vol. ii, p. 162, 1879.

Plates XII aud XIII, Figs. 80, 83-86.

The large and strong chelate claws, six-jointed pleon, and uropods with a short, one-jointed, outer ramus and a six-jointed inner ramus, will, in general, distinguish the present species from any other Isopod on our coast.

The body is of nearly uniform size throughont, and not constricted at the articulations. The head is narrowed in front. The eyes are conspicuous and plainly articulated, and are large in the males. The antenuulæ in the females (pl. XIII, fig. $\$ 4 a$ ) are shorter than the hearl and first thoracic segment, and are composed of three segments, of which the first is longer than the second and third together, and the third is slightly longer than the second, and, in some specimens, present traces of a division into two segments. The basal segment bears a short, stont seta just beyond the middle and one or two more near the tip; the second has also setie near the tip, and the third bears a tuft of half a dlozen or more setre at the tip. In the males (pl. XII, fig. S0) the antenuule are about two-thirds as long as the body and usually eleven-jointed, but sometimes with one or two segments more or less than that number. The basal segment forms, in this sex, about one-third the length of the organ, and is curved from near the base so as to be convex upward; the next two segments decrease rapidly in length, and are followed usually by eight flagellar segments provided with "olfactory setie" from two to four or more to a segment. The anteunæ (pl. XIII, fig. $\$+b$ ) in both sexes are short, slender, and decurved, termmated by a tuft of setre. They appear to vary but little in the fimily.

The first pair of legs lave the inerus triangular, bringing the ischinm and carpus together. In the female (pl. XIII, figs. 83 and $84 c$ ) these legs, in their natural position, extend but little beyond the head; the propodus has a stout, digital process nearly in the line of its axis; this process is broadly notehed near the base, then elevated into a slightly serrulate lobe, and bears at the apex a short, stout terminal tooth. Near the base of the lobe are usualiy two stont setæ. The first pair of legs in the males are much larger and more elongated, especially in the last three segments; the carpus is elongate and cyliudrical, extending about half its length beyond the head, and attaining the end of the basal antennular segment; the propodus (pl.

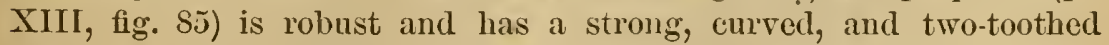
digital process, bearing also two stout setæe near the second tooth; the dactylus is also curved and provided on its inner margin with 
abont seren short setæe springing from the bases of as many serratures; the propodus bears on its inner surface, above the origin of the dactylus, a comb, formed by a row of short setx, and terminated at each end by a longer one. In the second pair of legs (pl. XIII, fig. $84 d$ ) the dactylns, with its terminal spine, is not as long as the propodus, which bears two or three setie near its tip. The third and fourth pairs of legs are shorter than the second. The last three pairs have their basal segments moderately swollen; the merus, carpus, and propodus of these legs are armed with a few spines near their distal ends; the dactyli are short.

The pleou is slightly broader near its base than the thoraeie segments. The first five segments are subequal in length, the last longer and pointed behind. The uropods (pl. XIII, fig. 86) consist of a robust basal segment $(b)$ bearing two rami, of which the onter $(o)$ is very short and uniarticulate; the inner $(i)$ is six-jointed, tapering from the base, with the segments of about equal length and provided with setæe near their distal ends.

\section{Length $2.2^{\mathrm{mm}}$; breadth $0.33^{\mathrm{mm}}$; color nearly white.}

It is possible that this species may prove to be identical with $L$. $E d$ wardsii (Kröyer) Dana, althongh differing from Kröyer's deseription* and figures, especially in the following particulars: The peduncle of the antennula, which, aceording to his description and figure, consists of a short basal segment, an elongated segment, and a third short segment, has bs his description the ratio to the following flagellum of five to four. The basal segment that he describes and figures was probably only the enlarged basal portion of the elongated segment, which, together with the following segment, constitutes only about three-serenths of the length of the organ instead of fire-ninths according to his description. He further deseribes and figures the mopod as biramous, with the inner elongated ramus composed of seven segments instead of six. Other differences conld be pointed ont in the proportions of the thoracic segments and the segments of the first pair of legs. Bate and Westwood $\dagger$ figure and deseribe a species, which they regard as $L$. $E d$ wardsii, altlongh their description and figures differ somewhat from Kröyer's, principally in the fact that they figure and describe the uropods as simple, saying in the generic description: "Pleopoda, five anterior pairs biramose; posterior pair unibranched and multiarticulate;" and again under the species (p. 136), "The posterior or caudal pair of pleoporla consist of a single multiarticulate branch, of which the basal joint is larger than the terminal ones: it consists of nine or ten small artienli." They figure it on page 134 as simple, tapering from the base and seven-jointed. These anthors express their indebtedness "for this iuteresting aldition to our British fauna to the zeal and ressarch of the Rev. A. M. Norman, who took it during the summer of

* Naturhist. Tidssk., rol. iv, p. 174, pl. ii, figs. 13-19.

† Brit. Sess. Crust., vol. ii, p. 134. 
1865 among Zosterce between tide marks in Belgrave Bay, Guernsey," and in the deseription of Paratanais foreipatus, on p. 139, mention in a foot-note a specimen from the same locality, "which has a pair of sixjointed anal filaments with a short one-jointed secondary filanent arising from the extremity of the basal joint. Can this be the female of Leptochelia Edwardsii fully grown?"

Through the kindness of the Rev. Mrr. Norman I have been able to examine a specimen labeled "Leptochelia Edwardsii, Guernsey, 1566," and do not find that it differs from our species in any eharacters that can be regarderl as of specific value. The antennulæ have indeed only seren flagellar segments, or ten segments in all, which is also the case in some of our speeimens, though eight such segments-eleven in all-is the usual number. The thoracie segments have the same proportion to each other as in our species, and the uropods agree exactly with ours in being biramous, with the outer ramus short and uniarticulate and the inner ramus six-jointed.

This is the form of uropod deseribed and figured by Kröyer in Tanais Savignyi, which, as Fritz Muiller has suggested, is probably the female of T. Edwardsii Kr. That speeies has, howerer, according to Kröyer, a five-jointed antennula, the last segment being rudimentary. I have observed among a large number of our specimens two which had the last segment divided, though searcely longer than in the others. These specimens could hardly be distinguished from T. Savignyi Kröyer by any characters that I have observed. In view, howerer, of the great similarity of the females throughout the genus, as exemplified in the females of this speeies and of $L$. rapax, with both sexes of which I am familiar, I hare concluded for the present to retain the specifie name which I recently proposed for this species, and wait until an examination of both sexes can be had to decide the questions of specifie identity.

I formerly regarded this species as identieal with Tanais filum Stimpson, and supposed its range to extend to the Bay of Fundy. In view of the number of species now known to exist on this eoast, and in the absence of any speeimens from the Bay of Fundy, $\mathrm{I}$ now regard that as an error, and have corrected it in the Ameriean Journal of Seience.

This species is rather abuudant among eel-grass (Zostera marina) and algæ at Noank! and Wood's Holl!, and has been taken during the past sunmer (1879) at Provineetown!, Mass., among eel-grass, on a vessel's bottom and in old piles, in company with Chelura terebrans Philippi and Limnoria lignorum White. The specimen sent by the Rev. A. M. Norman enables me to extend its range to the Island of Guernsey!, in the British Cliannel. 
Specimens examincd.

\begin{tabular}{|c|c|c|c|c|c|c|c|c|}
\hline \multirow{2}{*}{ 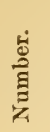 } & \multirow{2}{*}{ Locality. } & \multirow{2}{*}{ 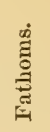 } & \multirow{2}{*}{ Bottom. } & \multirow{2}{*}{$\begin{array}{l}\text { When col- } \\
\text { lected. }\end{array}$} & \multirow{2}{*}{ Receivedfrom - } & \multicolumn{2}{|c|}{$\begin{array}{l}\text { Speri- } \\
\text { mens. }\end{array}$} & \multirow{2}{*}{$\begin{array}{l}\text { Dry. } \\
\text { Alc. }\end{array}$} \\
\hline & & & & & & No. & Sex. & \\
\hline 2126 & Noank Harbor, Conn & & Eel-grass ........ & --1874 & U.S. Fish. Com & 00 & 8 & Alc. \\
\hline 2127 & ... do ................. & & $\begin{array}{l}\text { Eel-grass and } \\
\text { alga. }\end{array}$ &,- 1874 & ... do .......... & 00 & & Alc. \\
\hline $\begin{array}{l}2128 \\
2129\end{array}$ & ...do ................... & & ....do .......... &,-- 1874 & ..... do .. & 10 & $\delta$ & Alc. \\
\hline 2129 & $\begin{array}{l}\text { Vineyard Sound, } \\
\text { Mass }\end{array}$ & & &,- 1871 & 100 & 1 & q & Alc. \\
\hline 2130 & $\begin{array}{c}\text { Vineyard Sound, } \\
\text { Parker's Point ... }\end{array}$ & & L. w, on algx.... &,- 1875 & $\ldots$...do & & & Alc. \\
\hline $\begin{array}{l}2131 \\
2132\end{array}$ & .... dlo ................. & & On piles......... & --1875 & ..... do . & $\cdots$ & & Alc. \\
\hline $\begin{array}{l}2132 \\
2133\end{array}$ & . do & & Surfice.... &,- 1875 & ....do . . & 3 & $q$ & Alc. \\
\hline & Provincetown, Mass. & $\mathbf{L}$ & (n) & $\overrightarrow{\text { Aug. }} \overline{22}, 1879$ & ...de. & 18 & 80 & $\begin{array}{l}\text { Alc. } \\
\text { Ale }\end{array}$ \\
\hline & ....... do do ............... & & Eel-grass ....... & Aug. 23,1879 & ....do .... & 24 & of & Alo \\
\hline & & & In old piles ...... & $\begin{array}{l}\text { Aug. } 23,1879 \\
\text { Aug. } 23,1879\end{array}$ & .... do $\ldots$..... & $\begin{array}{l}2 \\
1\end{array}$ & $\begin{array}{l}\text { O } \\
8 \\
8\end{array}$ & $\begin{array}{l}\text { Ala } \\
\text { Ala. }\end{array}$ \\
\hline & ...... do ........ & & Vossel bottom... & Sept. 3,1879 . & ....do ... & 2 & o' 9 & Alc. \\
\hline
\end{tabular}

Leptochelia limicola Harger.

Paratanais limicola Harger, Am. Jour. Sci., III, vol. xv, p. 378, 1878.

Leptochelia limicola Harger, Proc. U. S. Nat. Mus., 1879, vol. ii, p. 163, 1879.

Plate XIII, Figs. 87, 88.

I have seen only females of this species, and these in general much resemble the same sex in $L$. algicola described above, but differ as follows: The eyes are small and inconspicuons, being less than half the transverse diameter of the basal antennular segment. The second segment of the antenunla (pl. XIII, fig. $88 a$ ) is short, only about half as long as the third. In the second pair of legs the dactylus with its terminal claw or spine is longer than the propodus, and the claw is slender and attenuated. The pleon is not wider than the segments of the thorax, and the uropods have the onter ramus two-jointed and surpassing the basal segment of the inner ramus, which is five-jointed, with the first segment long and imperfectly divided.

Length $2.5^{\mathrm{mm}}$. Color white in alcohol.

The specimens of this speeies were dredged in 48 fathoms, soft mud, in Massachnsetts Bay!, oft' Salem, by the United States Fish Commission, in the summer of 1877 .

Leptochelia rapax Harger.

Leptochelia rapax Harger, Proc. U. S. Nat. Mus., 1879, vol. ii, p. 163, 1879.

Plate XIII, Figs. 89, 90.

Females of this species elosely resemble those of the two preceding speeies, but are distinguished by the following eharacters: The eyes are larger and more conspicuons than in $L$. limicola. The last segment of the antennulæ is scarcely longer than the preceding, instead of nearly twice as loug. In the second pair of legs the dactylus is somewhat shorter, and the terminal spine less attenuated. The extemal ramus of the uropods consists of a single very short and small segment, shorter than the basal segment of the inner ramus, which is not elongated. The 
inner ramus is five-jointed instead of six-jointed, as in $L$. algicola, from which species the males are easily distingnished by the elongate and slender antennula and chelate legs, and by other characters, as may be seen from the following description and the figures.

The males (pl. XIII, fig. 89) are remarkable for the long, slender hand terminating the first pair of legs (pl. XIII, fig. 90). The body of the male is short and robust, and the segments are well separated by constrictions at the sides. The head with the united first thoracic segment is short and rounded, bulging strongly at the sides just behind the eyes, which are conspicnons, considerably less in cliameter than the bases of the antennula, distinetly articulated and coarsely faceted. The antennulie are much elongated, especially in the basal segment, which constitutes nearly half the length of the organ, and is more than one-third as long as the body; this segment is straight, swollen on the inner side near the base, then tapers gradually to the tip; the second segment is a little over one-third the length of the first and eylindrical; the third is again about one-third the length of the second, and scarcely thicker than the following flagellar segments, which vary in number from six to eight, and are usually of abont equal length. In case there are eight flagellar segments the first is, sometimes at least, considerably shorter than the others. The last segment is tipped with a rudiment, and bears a few setie. The whole number of segments, therefore, varies from nine to eleven, and if one of the flagellar segments be taken as a unit of measurement, the length of the first three segments will be approximately expressed by the numbers $9,3.8$ and 1.4. The antenna when extended do not far surpass the middle of the basal segment of the antenumle, and are comparatively slender; the first segment is short and somewhat expanded distally; the second is slightly longer and expanded so as to be sub-cordate; the third is short and cylindrical, equal in length to the first; the fourth is the longest segment, being longer than the first three taken together, and is slender and cylindrical, with a few setre near the tip; the fifth is more slender and but slightly shorter than the fourth, and is tipped with a minute rudimentary terminal segment and a few setx.

The legs of the first pair are large and much elongated. They vary somewhat in size and proportions, but are commonly, when extended, longer than the body of the animal. In these legs the segments preceding the carpus are robust but comparatively short, while the carpus is about half as long as the body, and the propodus (pl. XIII, fig. 90) is even more elongated than the carpus, and is usually strongly flexed upon it. More than half the length of the propodus is made up of the slender digital process, which bears, near the base on the inner side, a low, obtuse tooth, and a larger and more prominent one near the slender incurved tip. The dactylus (pl. XIII, fig. 90) is more than half as long as the propodus, slender, curved, and pointed, and armed with scattered, weak spinules along the inner margin. The digital process of the pro- 
podus bears also a few setæ, especially near the base of the outer tooth. The forceps thus formed are in most eases large enough to close around the body of another individual, but vary in size, being in some specimens at least one-third smaller than in others. The basal antennular segment may also be somewhat shorter than above describerl.

Of the thoracic segments the second (first free) segment is the shortest, and is also slightly broader than the others, and broader than the head. The third, fourth, and fifth segments increase in length progressively; the sixth is as long as the fifth; the serenth shorter. In the second pair of legs, the dactylus with its terminal claw is about as long as the propodus and nearly straight, as it is also in the third and fourth pairs, but the dactyli of the last three pairs of legs are more curved, and the basal segments somewhat swollen.

The first five segments of the pleon are of about equal length. The sixth is slightly shorter, obtusely pointed in the middle, and emarginate above the bases of the uropods, which are composed of a robust basal segment, bearing a minute onter ramus composed of a single segment tipped with setæ, and a five-jointed inner ramus, also sparingly provided with setr. Between the mropods and below, a thin spatulate plate projects beyond the extremity of the pleon.

In length the males vary from $2.6^{\mathrm{mm}}$ to $3.8^{\mathrm{mm}}$, and in breadth from $0.6^{\mathrm{mm}}$ to $0.85^{\mathrm{mm}}$. The females measure in length about $2.3^{\mathrm{mm}}$; in breadth, $0.5^{\mathrm{mm}}$.

About one hundred specimens of this species, three-fourths of them females, were collected by Prof. A. Hyatt and Messrs. Van Vleck and Gardiner, in three feet of water, on mudds bottom, in the summer of 1878, at Annisquam!, Mass., and are the only specimens I have seen.

Leptochelia filum Harger (Stimpson).

Tanais filum, Stimpson, Mar. Inv. G. Manan, p. 43, 1853.

Packard, Mem. Bost. Soв. Nat. Hist., vol, i, p. :296, 1867.

Harger, Am. Jour. Sci., III, vol. xv, 1. 378, 1878.

Leptochelia filum Harger, Proc. U. S. Nat. Mus., 1879, vol. ii, p. 164, 1879.

"Very minnte, slender, ronnded on the back, white, looking very much like a short piece of thread. Head small, and rather narrowed in front; first thoracic segment of. great length; the second half as long as the third, which is about equal in length with the fourth, fifth, and sixth; the seventh being a little shorter than the sixth. The segments of the abdomen are well defined, the first five equaling each other in length, and the terminal one longer than the fifth, but narrower, and rounded behind. Antennæ short and thick, withont flagellæ, with blunt tips crowned with few hairs, as are also their articulations. 'The inner ones are directed forward, and much the stoutest, especially toward their bases; while the outer ones are more slender and curve outward and backward. First pair of legs exceedingly thickened, with rery large ovate hands and strong curved fingers. They are generally closely applied against 
the breast. The remaining thoracic feet are very slender, terminating in sharp, slender fingers, which in the second pair are rery long and nearly straight, and in the other pairs short. The legs of the posterior pair are a little the longest and thickest. The ambulatory feet, in firo pairs, are of great length and resemble those of Amphipods. The candal stylets are in length about fonr-fifths that of the abdomen, and consist of tour or five articles, with few hairs, each article becoming narrower, the last one with a tult of few hairs at its extremity. Length .15 inch; breat th .02. Dredgerl among Ascidice cullose, in 20 fathoms, in the Hake Bay."

I have seen no speeimens corresponding fully with the above description, which is copied fiom Dr. Stimpson; neither have I seen any specimells of this family from the Bay of Fundy. I formerly regarded the species from Vineyard Sound as Tancis filum Stimpson, and that name is used in this Report, part i, 1) 573 (279), where also "Bay of Fundy to Vineyard Sound" is given as its range. This error was corrected by the writer in the American Journal of Science in 1878. In the absence of specimens from the Bay of Fnndy I am unable to say positively that this species is not the same as my $P$. limicola, although the number of segments in the mopods does not correspond with those of that species, and the onter ramus of the uropods, which is rather conspicuous in that species, is not mentioned at all by Dr. Stimpson. Further investigation is needed to settle this question, but the number of species known to me from the coast seems sufficient warrant for regarding this, for the present at least, as a distinct species.

Dr. Packard states that he has dredged Tanais filum Stimpson in the Gulf of St. Lawrence, "at Caribou Island, in eight fathoms, on a sandy bottom."

\section{Leptochelia cœea Harger.}

Paratanais cœca HIarger, Am. Jour. Sci., III, vol. xr, p. 378, 1878.

Leptochelia cœea Harger, Proc. U. S. Nat. Mus., 1879, rol. ii, p. 164, 1879.

Plate XIII, Fig. 91.

This species is at once recognized among our Tanaids by the absence of eyes. The enlarged chelate claws joined to the united head and first thoracie segment, and the six-jointed pleon serve to distinguish it as belonging to the present genus.

Borly slender, elongated, and rather loosely articulated; head narrow in front, not broader than the bases of the antennula; eyes wanting; antenuulre distinctly four-jointed (pl. XIII, fig. 91 $a$ ) in the type speei. men, first segment forming less than half the length of the organ, sec. ond segment longer than the third, last segment about as long as the second, slender, tapering and tipped with setæ; antennæ attaining the tip of the thircl autennular segment. The first pair of legs (pl. XIII, fig. $91 b$ ) are robust, but less so than in the preceding species; they 
extend forward in the natural position about to the tips of the antemn; they have the basal segment subquadrate, the hand or propodus less robust than the carpus, with a serrated digital process; dactylus short.

The second, or first free, thoracic segment is about two-thirds as long as the third; this in turn is about equal to the fourth and to the fifth segments; while the sixth and seventh segments are progressively somewhat shorter. The second pair of legs are scarcely more slender than the following pairs, and the basal segments are not curved around the base of the first pair.

The uropods (pl. XIII, fig. 91c) are short, and biramous; each ramus two-jointed. The onter ramus is more slender than the inner, half its length, and bears a long bristle at the tip.

Length $2.5^{\mathrm{mm}}$; color white.

The first specimen of this species was dredged along with $L$. limicola in 48 fathoms, soft mud, Massachusetts Bay!, off Salem, in the summer of 1877 , and a second specimen apparently of the same species, though differing somewhat in the antemula, was collected on the shore at Provincetown! during the summer of 1879 . Unfortunately only a single specinen was obtained in each case, but it is very distinct from the other species of our coast. It does, howerer, closely approach Tanais islandicus G. O. Sars, * but appears to differ in the first pair of legs, which Sars describes as follows: "Pedes primi paris validi, manu sat dilatata, carpo vix angustiore, digitis palma longitudinem requantibus vix forcipatis." These legs are in our species distinctly chelate, and the dactylus is much shorter than the propodus (see pl. XIII, fig. 91b). He further says: "Uropoda sat elongata, biramosa, ramis, ambobus biarticulatis, valde inæqualibus, exteriore ne $3^{\text {tiam }}$ quidem interioris longitudinus partem assequente." In our species the outer ramus of the uropod is about one-half as long as the inner.

\section{GEOGRAPHICAL DISTRIBUTION.}

The whole number of species enumerated is forty-six, three more than were included in my recent paper on New England Isopoda in the Proceedings of the United States National Museum. Their geographical distribution, especially on our coast, is summarized in the lists below.

The following eleven species have as yet been found only south of Cape Cod:

Scyphacella arenicola. Actoniscus ellipticus. Cepon distortus. Bopyrus species. Erichsonia filiformis. Erichsonia attenuata.

Cirolana concharum. Nerocila munda. Egathoa loliginea. Lironeca ovalis. Tanais vittatus. 
The following nineteen have been found only north of Cape Cod:

Gyge Hippolytes.

Phryxus abdominalis.

Dajus mysidis.

Janira alta.

Janira spinosa.

Mtumua Fabricii.

Mumnopsis typica.

Eurycope robusta.

Syniclotea nodulosa.

Synidotea bicuspida.
Astacilla granulata.

Cirolana polita.

Asga psora.

Syscenus infelix.

Gnathia cerina.

Leptochelia limicola.

Leptochelia rapax.

Leptochelia filum.

Leptochelia cœca.

The remaining sixteen are included in the following list as found on both sides of Cape Cod, but the letter N. is used to designate such species as are eommon north and rare south of the Cape, and s. signifies that the species is common at the south but rare northwards.

Philoscia vittata, $\mathbf{s}$.

Jæra albifrons.

Ilyarachna species.*

Chiridotea cœea.

Chiriclotea Tuftsii, N.

Idotea irrorata.

Idotea phosphorea, N.

Idlotea robusta.
Epelys trilobus, s.

Epelys montosus, N.

Sphæroma quadridentatum, s.

Limnoria lignorum.

Anthura polita, s.

Paranthura brachiata, $\mathrm{N}$.

Ptilanthura tenuis.

Leptochelia algicola, s.

The eleven species included in the following list occur also on the coast of Europe. The British species are marked $\mathrm{B}$.

Gyge Hippolytes, B.

Phryxus abdominalis, $\mathbf{B}$.

Jæra albifrons, B.

Munna Fabricii.

Munnopsis typica.

Idotea irrorata, $\mathbf{B}$.
Astacilla granulata.

Limnoria lignorum, $\mathbf{B}$.

Ega psora, B.

Tanais vittatus, $\mathbf{B}$.

Leptochelia algicola, $\mathbf{B}$.

The number of Isopoda included in the present paper is considerably less than are known to inhabit Great Britain, being only about twothirds as many as are included in Bate and Westwood's work, together with such additions to that fauna as have come to my knowledge since. As has been seen, eight, or nearly one-fifth of our marine species, are identical with those of Great Britain. The number of genera is much more nearly equal. Thirty-one marine genera are enumerated in the present paper, and of these sixteen are also British. The remaining fifteen do not appear to be represented on the British coast, but their place is filled by perhaps a rather greater number of genera. Of tho families, neglecting the Oniscidce as not properly included in the present paper, we come to the Bopyridce, which have as yet been but little studied

\footnotetext{
* The only specimen yet known is from twenty-one miles east of Cape Cod.
} 
on this coast. Five species only are enumerated here, two of which are also British, while Bate and Westwood enumerate twelve. A closer ex. amination of the gronis may rers likely add considerably to the present list.

The Ascllide and ITunnopside, which Bate and Westwood would unite, have seren marine species belonging to six genera in our list, and, rejecting Limnoria, this number corresponds well with the British list of four genera and six species; one species, Jora albifrons Leaeh, is identical, as are three of the genera-Jcera, Janira, and Mnnna. The more typical forms of the Nunnopside have not yet, as far as I am aware, been recognized in British waters.

The Idloteide are more numerous on our coast and appear to be more diversified than in Great Britain. I have regarded our eleven species as belonging to five different genera, while Bate and Westwood include the seven British species in a single genus. The most conservative could hardly class our speeies in less than three genera to one English genus, and, judging mostly from the figures and descriptions, I should be inclined to reckon three, or at least two, English genera to five on our eoast in this family. One genus and species, Idotea irrorata Edw. (Say), is identical. Of the Arcturide a single representative has only recently been discovered within our limits, while three species, of the same geuns as ours, are mentioned by Bate and Westwood, and Stebbing has since added two more species.

A single species of Spharoma is the only representative on our coast of a family numbering no less than five genera and thirteen species in Bate and Westwood's volume. If the last two of these species be united as sexes of the same, and Dynamene rubra and viridis be also united, as suggested by Stebbing, there are still left eleven representatives of this family in England to one on our coast. Our species is closely related to the British Sphceroma serratum Leach. Limnoria lignorum White is the only known representatire of its family on both coasts.

The Cirolanide and Egida, which are classed together under the latter name by most authors, have ouly four representatives in our limits, belonging to three genera. Two of these genera are also found in Great Britain, where they eontain no less than seren species, one of which, Eya psora Liröyer, is identical on the two coasts. Cirolana truncata Norman is not included in Bate and Westwood, but these authors mention three other species belonging to as many genera in this group, making five genera and ten species from Great Britain to ouly three genera and four species in onr waters. The Cymothoida are represented in our list by three speeies belonging to three genera, while Bate and Westwood say of this family, "No specimen has hitherto been satisfactorily determined as having been found in our own seas." The Rer. A. M. Norman, howerer, in the Ammals and Nagazine of Natural History for December, 1S68, p. 422, mentions and briefly describes Anilocra medi- 
terranea Leach, taken from a "small fish in rock-pools at Herm in 1865." This genus has not been found on our coast.

Of the three genera and three speeies of Anthuride in our list two genera are also found in Great Britain, and it is possible that one species may yet prove identical. The Gnuthiide are more diffieult of comparison on account of the confusion that has existed in the sexes, and the larval forms. Our specimens seem to be all referable to a single species, doubtless eongeneric with the British species, the number of which may, perhaps, by a liberal estimate, be placed at three.

In the Tanaide, the genera are the same as in Great Britain, and two of our species, Tanais vittatus Lillj. and Leptochclia algieola Harger, are found on both coasts. There remain a seeond speeies of Tanais on the British coast, and two species of Leptochelia (Paratanais of Bate and Westwood) against four species of Leptochelia on our coast, as the remaining representatives of this family. The genus Apseudes should probably be taken to represent a family not yet found on our eoast.

We have, therefore, the following list of marine familes, with the genera in each, that are identical on our coast and that of Great Britain. The species have been already indicated in a preceding list:

Bopyrida: Gyge, Phryxus, Bopyrus. Two species.

Asellidæ: Jæra, Janira, Munna. One species.

Idoteida: Idotea. One species.

Arcturidæ: Astacilla.

Sphæromidæ: Sphæroma.

Limnoriidæ: Limnoria. One species.

Cirolanidæ: Cirolana.

Agidre: AEga. One species.

Cymothoidæ.

Anthuridæ: Anthura, Paranthura.

Gnathiidæ: Gnathia.

Tanaidæ: Tanais, Leptochelia. Two species.

Furtler details of geographical and also of bathymetrical distribution are presented in the table on pages 139 to 141 , in which the first column shows the least depth in fathoms at which each species has been collected on our coast; the second the greatest depth; and the following eighteen columns are for different localities, which may be further explained as follows: The Carolinas include Charleston, S. C., Fort Macon, N. C., and Norfolk, Va.; New Jersey includes Great Egg Harbor and Atlantic City, N. J., and Fire Island Beach, on the south shore of Long Island; Long Island Sound includes Savin Rock, New Haven, Stony Creek, or Thimble Islands, Saybrook, New London, and Norwalk, Conn.; Block Island inchudes Wateh Hill, Block Island Sound, and the deeper water off the island; Vineyard Sound includes also Buzzard's Bay, Nintucket Sound, and off Nautucket Island; Cape Cod Bay includes Provincetown and Barnstable; Massachusetts Bay includes Salem, Nahant, Glou- 
cester, and Annisquam, Mass.; the Gulf of Maine includes all outside of the line of 50 fathoms between Cape Cod and Nova Scotia, and extending seaward to inclnde George's Banks; Casco Bay includes Capo Elizabeth and Quahog Bay; Bay of Fundy includes Eastport Harbor and Grand Menan, while species collected at greater depths than 50 fathoms are reckoned also in the Gulf of Maine, and the same is true of those from that depth off Nova Scotia; Nova Scotia includes also Banquereau or Querean, Eastern and Western Banks, Miquelon Island, and the Grand Banks. Species occurring on the north shore of the Gulf of St. Lawrence are credited also to Labrador. In the last column of the table the general habitat of each species is briefly indicated. 


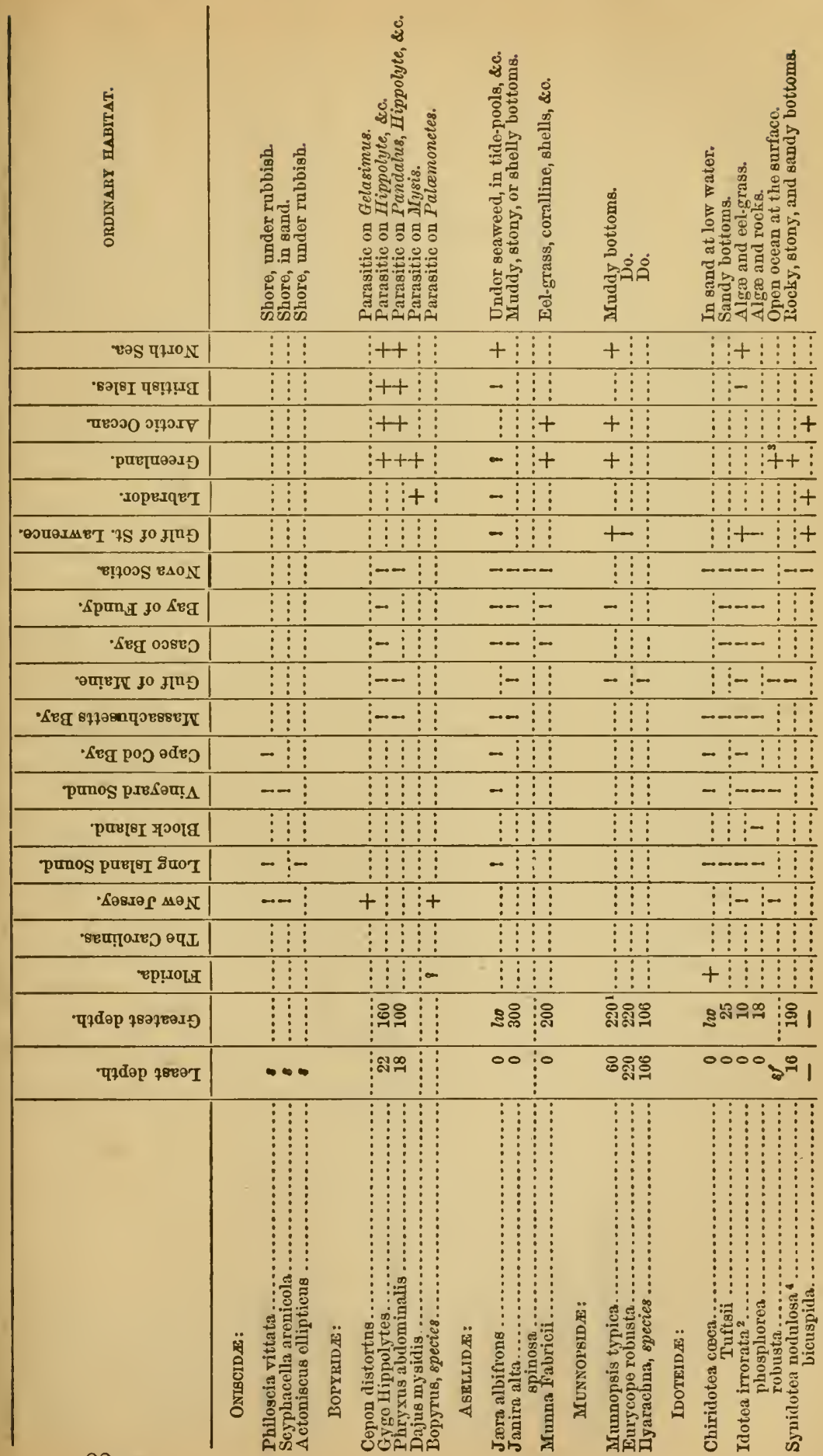


434 REPORT OF COMMISSIONER OF FISH AND FISHERIES.

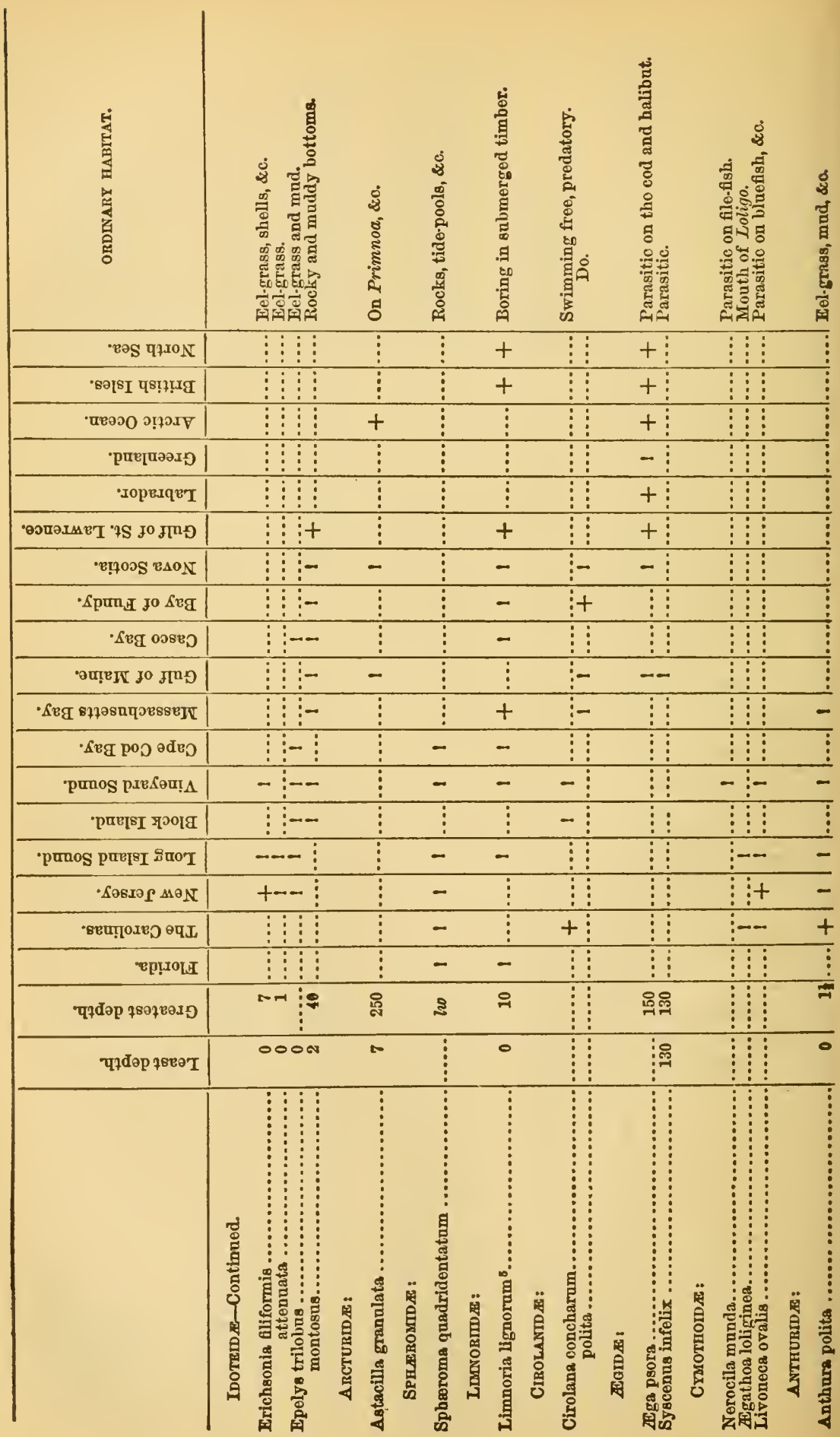


MARINE ISOPODA OF NEW ENGLAND, ETC.
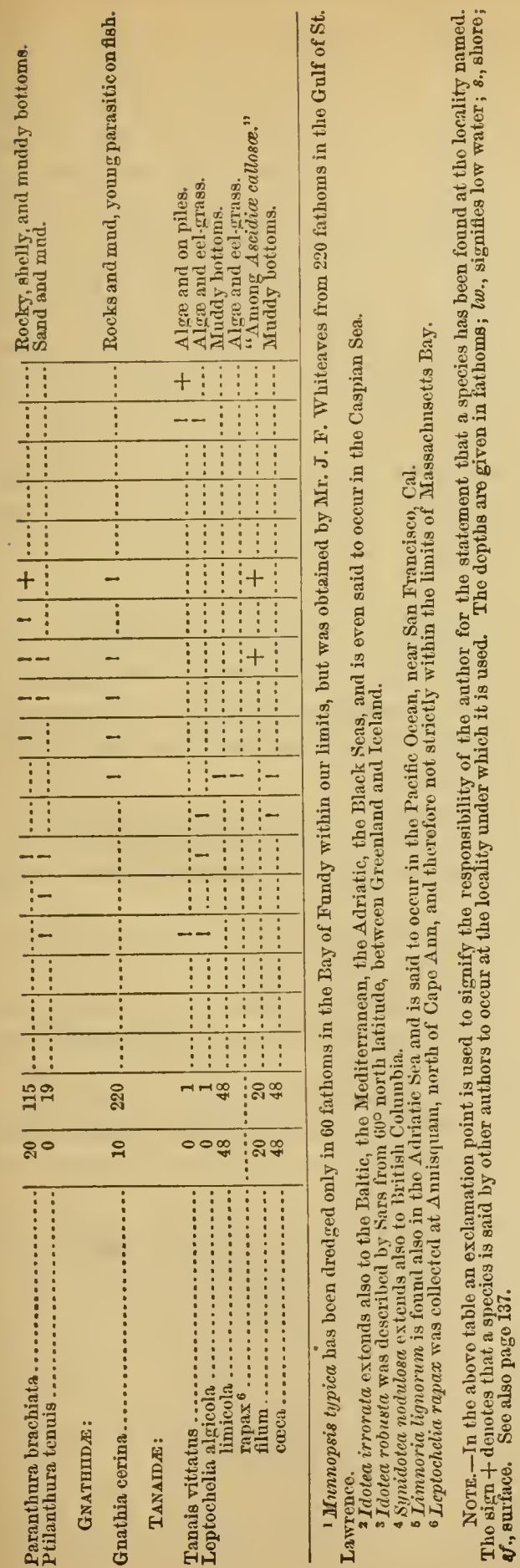


\section{LIST OF AUTHORITIES.}

The present list includes only such works and artieles, relating wholly or in part to Crustacea, as have been quoted, or otherwise used, in the preparation of the preceding paper, and is ehiefly intended to aid in consultation of the anthorities quoted. A few of the titles are necessarily given at second haud, as indicated by quotation marks in the list. The references to these works oceurring throughout the article are also inclosed in quotation marks, usually with an aceompanying mention of the author from whom they are taken. In all other eases the references have been made direetly from the works quoted. A considerable number of anthorities have not been referred to, and are omitted from the list, becallse at present inaeeessible, and, for many of the most important works that $I$ have been able to eonsult, I am indebted to the liberality of Professor S. I. Smith, who has given me the free use of his library and afforded other material aid in the preparation of the article. I have also had free access to the libraries of Professors Verrill, Marsh and Dana.

In this list, as throughout the article, the number of the series of varıous seientific publications is indieated by Roman numerals in cap. itals. As far as possible references have been made to the original paging, sometimes with that of the separata adderl in a parenthesis, and, in the following list, a parenthesis is used to denote that the paging is, or is supposed to be, that of the separata.

Agassiz, Alexander. Letter to C. P. Patterson, Superintendent Coast Survey, on the dredging operations of the U. S. Coast Snrvey steamer "Blake" during parts of January and February 1878. < Bulletin of the Mnseum of Comparative Zoology, vol. v, pp. 1-9. Cambridge, 1878.

Andrews, A. [Limnoria terebrans attacking telegraph cable.] < Quarterly Journal of Microscopical Science, II, vol. xv, p. 332. London, 1875.

Audouin, Jean Victor, and Edwards, Henri Milne. "Résumé d'Entomologie, ou d'Histoire naturelle des animaux articulss, complété par une iconographie de 48 planches. [2 vols.] Paris, 1828-29."

Audouin, Jean Victor, and Edwards, Henri Milne. Précis d'Entomologie ou d'Histoire naturelle des animanx articulés. Première division, Histoire naturelle des annélides, crustacés, arachnides et myriapodes, complété par une iconographie. [8vo, 70 pages, 48 plates.] Paris, 1829.

Audouin, Jean Victor. Description de l'Égypte ou recueil des observations, et des recherches qui ont ́́té faites en Egypte pendant l'expedition de l'armée Française. Explication sommaire des planches de crustacés de l'Ksgypte et de la Syrie. Pub. liées par J. C. Savigny. Histoire naturelle, tome i, pt. 4, pp. 77-98. Paris, "1830."

Bate, C. Spence. On the British Edriophthalma. < Report of the British Association for the Advaneement of Science, 1855, Reports on the state of science, pp. 18-62, pl. xii-xxii. London, 1856.

Bate, C. Spence. On Praniza and Anceus and their affinity to each other. < Annals and Magazine of Natural History, III, vol. ii, pp. 165-172, pl. vi-vii. London, Sept., 1858.

Bate, C. Spence. Crustacea. [ $\mathrm{In}]$ List of the British marine invertebrate fauna. By Robert McAndrew. < Report of the British Association for the Advancement of Science. 1860. Renorts on state of science, pp. 217-236. London, 1861. 
Bate, C. Spence. Carcinologrical gleanings, No. ii. < Annals and Magazıne of Natural History, III, vol. xvii, pp. 24-31, pl. ii. London, 1866.

Bate, C. Spence, and Westwood, Johu Obadiah. A History of tho British sessileeyed Crustacen. [2 vols. 8vo.] Lonilon, 1861-1868.

Beneden. See Van Beneden.

Bos, Jan Ritzema. Bijltrage tot do kennis van do Crustacea hedriophthalmata van Nederland en zijue Kusten. [8vo., 100 pages, 2 plates.] Groningon, 1874.

Bosc, Louis Augustin Guillaume. Histoire naturello des Crustacés, contenant leur description et leurs mors; avec figures dessinées d'après nature. [12mo., vol. ii, 296 pagres, 18 plates.] Paris, An x (1802).

Buchholz, Reinhold. Zweite Deutsche Nordpolfahrt "in den Jahren 1869 und 1870, unter Führung des Kapitän Koldewey." B. ii, Part viii, Crustaceen, pp. 262-399. pl. i-xv. Leipzig, 1874.

Buchholz, Reinhold. Mittheilungen naturwiss. Vereins v. Neu-Vorpom. n Rügen, i, pp. 1-40. See Münter, Julius.

Bullar, John Follett. The generative organs of the parasitic Isopoda. < Journal of Anatomy and Physiology, vol. xi, pp. 118-123, pl.iv. Londou and Cambridge, 1876.

Bullar, John Follett. Hermaphroditism among the parasitic Isopoda; reply to Mr. Moseley's remarks on the generative organs of the parasitic Isopoda. < Annals and Magazine of Natural History, IV, vol. xix, pp. 254-256. London, 1877.

Catta, J. D. Note sur quelques Crustacés erratiques. < Annales des Sciences naturelles, Zoologie, VI, tome iii, pp. 1-33, pl. i-ii. Paris, 1876.

Coldstream, John. On the structure and habits of the Limnoria terebrans, a minute crustaceous animal destructive to marine wooden crections, as piers, etc. < Edinburgh New Philosophical Journal, vol. xvi, pp. 316-334, pl. vi, 1834.

Cornalia, Emilio, and Panceri, Paolo. Osservazioni zoologico ed anatomische sopra un nuoro genre di Isopodi sedentari (Gyge brauchialis). < Memorie della Roalo Accademia delle Scienze di Torino, II, tom. xix, pp. 85-118, pl i-ii. Turin, 1861.

Cuvier, Georges. Le Règne Animal. See Edwards, Henri Milne, and Latrellle, Pierre Andre.

Czerniavski, Voldemar. Materialia ad Zoographiam Ponticam comparatam. "Transactions of the first meeting of Russian Naturalists at St. Petersburg, 186s." pp. 19-136, pl. i-viii. "18\%0."

Dalyell, John Graham. The Powers of the Creator displayed in the Creation. [3 vols., 4to, 145 plates.] London, 1851-1858.

Dana, James Dwight. Conspectus Crustaceorun, \&c. Conspectus of the Crustacea of the Exploring Expedition * * continued. Crustacea Isopoda. <American Journal of Science and Arts, II, vol. viii, pp. 424-428. New Haven, 1849.

Dana, James Dwight. On the classification of the Crustacea choristopoda or tetradecapoda. < American Journal of Science and Arts, II, vol. xiv, pp. 297-316. New Haven, 1852.

Dana, James Dwight. Report on the Crustacea of the United States Exploring Ex. pedition, nnder the command of Charles Wilkes, U. S. N., 1838-42. Washington, Text [4to, two parts, 1618 pages], 1853. Atlas [folio, 96 plates], 1855.

Dekay, James E. Zoology of New York or the New York Fauna. Part iv, Crustacea. [4to, 70 pages, 13 plates.] Albany, 1844. 
Desmarest, Ansleme Gaetan. Malacostracés. <Dictionnaire des Sciences naturelles, tome xxviii, pp. 138-425 [56 plates]. Paris, 1823.

Desmarest, Ansleme Gaetan. Considerations générales sur la classe des Crustacés. [8vo, 446 pages, 56 plates.] Paris, 1825.

Dohrn, Anton. Untersuchungen iiber Bat und Entwieklung der Arthropoden. 4. Entwicklung nud Organisation von Praniza (Anceus) maxillaris. <Zeitselurift für wissenschaftliche Zoologie, Band $\mathrm{xx}$, pp. 55-80, taf. vi-viii.-5. Zur Kentniss des Baues von Paranthura Costaua. <Tom. cit. pp. 81-93, taf. ix. Leipzig, 1870.-7. Znr Kentniss vom Bau und der Entwicklung von Tanais. < Jenaische Zeitschrift fïr Medieiu und Naturwissenschaft, Band v, pp. 293-306, taf. xi-xii. Leipzig, $18 \pi 0$.

Duvernoy, George Louis. Sur un nouvean genre de l'ordre des Crustacés Isopodes et sur l'espèce type de ce genre, le Képone type. <Annales des Sciences naturelles, Zoologie, II, tome xv, pp. 110-122, pl. iv B. Paris, 1841.

Duvernoy, George Louis, and Lereboullet, Auguste. Essai d'une monographio des organes de la respiration de l'ordre des Crustacés Isopodes. <Annales des Sciences naturelles, Zoologie, II, tome xv, pp. 177-240, pl. vi. Paris, 1841.

Ebner, Victor von. Helleria, eine neue Isopoden-Gattung aus der Familie der Oniscoiden. <Verhandlumgen k. k. zoologisch-botanischen Gesellschaft, Wien, Band xviii, pp. 95-114, pl. i. Vienua, 1868.

Edwards, Alphonse Milne. Sur un Isopode gigantesque des grandes profondeurs de la mer. <Comptes Rendus, tome lxxxviii, pp. 21-23. Paris, 1879.

Translated in the Aunals and Magazine of Natural History, V, vol. iii, pp. 241243. London, 1879.

Edwards, Henri Milne. "Résumé d'Entomologie" and Précis d'Entomologie. See Audouin, Jean Victor.

Edwards, Henri Milne. Annotations in Histoire naturelle des animanx sans vertèbres, par J. B. P. A. de Lamarck, 2me Edit., tome r, 8vo. Paris, 1838.

Edwards, Henri Milne. Histoire naturello des Crustacés, comprenant l'anatomie, la physiologie et la elassifieation de ces animanx. [8vo, 3 vols. text, 1 vol. plates. ] Paris, tome i, 1834, tome ii, 1837, tome iii, 1840.

Published as a part of the Suites à Bufton.

Edwards, Henri Milne. Le Règne Animal distriluué d'après son organisation, par Georges Cuvier. Les Crustacés avec une atlas. [Crochard edition, text 4to, 278 pages, atlas with 87 plates.] Paris, "1849."

Edwards, Henri Milne. Observations sur le squelette tégumentairo des Crustacés Déeapodes ot sur la Morphologie do ees Animaux. <Annales des Sciences naturelles, Zoologie, III, tome xvi, pp. 2:1-291, pl. viii-xi. Paris, 1851.

Edwards, Henri Milne. Rapport sur un trafail de M. Hesse relatif aux metamorphoses des Ancées et des Caliges. <Amales des Sciences naturelles, Zoologie, IV, tome ix, pl. 89-92. Paris, 1858.

Eichwald, Eduard voll. "Faunæ Caspio-Caucasi:e illustrationes universæ. < Noveaux Mŕmoires de la Société Impériale des Naturalistes de Moscou, yol. vii. Moscow, 1842."

Fabricius, Johann Christian. Entomologia Systematica emendata et aucta secundum elasses, ordines, genera, species, adjectis synonimis, locis, observationibus, deseriptionibus. [8ro, 4 vols., vols, $\mathrm{i}$ and iii in two parts]. Hafniae (Copenhagen) 1792-1794. Index alphabeticus. [175 pages]. 1796. 
Fabricius, Johann Christian. Supplementum Entomologix Systematicx. [8vo, 572 pages.] Hafuiae (Copenhagen) 1798. Index alphabeticus. [53 pages.] 1799.

Fabricius, Otho. Fauma Groenlandica. [8vo, 450 pages, 1 plate.] Copenhagen, 1780.

Fleming, John. Crustasea. <Éncyclopodia Britannica, 7th edition, vol. vii, pp. 497-504, pl. clxxx-clxxxi, 4to. Edinburgh (184:).

Fraisse, Paul. Die Gattung Cryptoniscus Fr. Müller (Liriope Rathke). <Arbeiten aus dem Zoologisch-zootomischen Institut in Würzburg, Band iv, pp. 239-296, taf. xii-xv, 1878.

Gaimard, Paul. Voyages en Scandinavie, etc. See Kröyer, Henrik.

Gegenbaur, Carl. Elements of Comparative Anatomy. Translated by F. Jeffrey Bell, the translation revised by E. Ray Lankester. [8vo, 645 pages.] London, 1878.

Geoffroy, Étienne Louis. "Histoire abrégée des Insectes qui se trouvent aux environs de Paris, dans laquelle ces animaux sont rangés suivant un ordre m6thodique. Paris, 1762, 1800, 2 vols., 4to."

Goodsir, Henry D. S. On two new species of Leachia, with a plate. < Edinburgh new Philosophical Journal, vol. xxxi, pp. 309-313, pl. vi. 1841.

Gosse, Philip Henry. A Manual of Marine Zoology for the British Isles. [Two parts, small 8vo.] London, 1855-1856.

Gould, Augustus Addison. Crustacea [List of, in Massachusetts]. < Report on the Geology, Mineralogy, Botany, and Zoology of Massachusetts. 2d edition. By Edward Hitchcock. pp. 548-550. Amherst, 1835.

Gould, Augustus Addison. Report on the Invertebrata of Massachusetts, comprising the Mollusca, Crustacea, Annelida and Radiata. [8vo, 373 pages, 15 plates.] Boston, 1841.

Griffith, Edward, and Pidgeon, Edward. The Classes Annelida, Crustacea and Arachnida arranged by the Baron Cuvier, with supplementary additions to each order. [8vo, 540 pages, 59 plates. $]$ London, 1833.

Grube, Adolph Eduard. Ein Ansflug nach Triest und dem Quarnero. Beiträge zur Kentniss der Thierwelt dieses Gelietes. [8vo, 175 pages, 5 plates.] Berlin, 1861.

Guérin Méneville, Felix Edouard. Iconographie du Regne Animal de Cuvier. A vec un texte descriptif mis au courant de la science. Crustacés. [8vo, 48 pages, 35 plates.] Paris, 1829-1843.

Guérin Méneville, Felix Edouard. Expedition Scientifique do Morée, Section deg Sciences physiques, tome iii, pt. i, Zoologie, section ii. Des Animaux articulés. Crustacés, pp. 30-50. pl. xxvii. Paris, 1832.

Harger, Oscar. The sexes of Sphrroma. <American Journal of Science aud Arts, III, vol. v, p. 314. New Haven, 1873.

Harger, Oscar. On a new genus of Asellidæ. <American Journal of Science and Arts, III, vol. vii, pp. 601-602. New Haven, 1874.

Harger, Oscar. This Report, part i, pp. 569-573. See Verrill, Addison Emory.

Earger, Oscar. Traus. Conn. Acad., vol. iii, pp. 1-57, and This Report, part ii, pp. 657-661. See Smith, Sidney Irving.

Harger, Oscar. Description of Mancascllus brachyurus, a new fresh water Isopod $<$ American Journal of Science and Arts, III, vol. xi, pp. 304-305. New Haven, 1876. 
Harger, Oscar. Deseriptions of new genera and species of Isopoda, from New England and adjacent regions. <American Jourual of Science and Arts, III, vol. xv, pp. 373-379. New Haven, 1878.

Harger, Oscar. Notes on New England Isopoda. < Proceedings of the United States National Museum, 1879, vol. ii, pp. 15\%-165. Separata, Washington, 1879. [List of Bopyridæ by Prof. S. I. Smith.]

Heller, Camill. Carcinologischo Beiträge zur Fauna des adriatischen Meeres. $<$ Verhandlungen der k. k. zoologisch-botanischen Gesellschaft in Wien, Band xvi, pp. 723-760. Vienua, 1866.

Heller, Camill. Diø Crustaceen, Pycnogoniden und Tunicaten der k. k. Osterr-Ungar Nordpol-Expedition. < Denkschriften der mathematisch-naturwisseuschaftlichen Classe der kaiserlichen Academic der Wissenschaften, Band xxxv, pp. 25-46, taf. i-v. Vienna, 1875.

Hesse, Fugène. Mémoire sur les Pranizes et les Ancées (extrait). <Annales des Sciences naturelles, Zoologie, IV, tome ix, pp. 93-119. Paris, 1858.

Hesse, Eugène. Memoir on the Pranizæ and Ancei (abstract). <Annals and Magazine of Natural History, III, vol. xiv, pp. 405-417. London, 1864.

Hesse, Eugène. Mémoire sur les Pranizes et les Ancées. <Ḿ́moires présentés par divers savants à l'Académie des Sciences de l'Institut Impérial de France, tomo xviii, pp. 231-302, pl. i-iv. Paris, 1868.

Hesse, Eugène. Observations sur des Crustacés rares ou nonveaux des cótes do Frauce. $15^{\text {me }}$ article. Description d'uu nouveau crustacé appartenant au genre Limnorie. < Annales des Sciences naturelles, Zoologie, V, tome x, pp. 101-121, pl. ix. Paris, 1868.

Hitchcock, Edward. A Catalogue of the animals and plants of Massacliusetts, VI, Crustacea. < Report on the Geology, Mineralogy, Botany, and Zoology of Massachusetts, pp. 563-564. Amherst, 1833.

Hope, Frederick William. "Observations on the ravages of Limnoria terebrans, with suggestions for a preventative against the same. < Transactions of the Entomological Society, vol. i, pp. 119, 120. London, 1836."

Hope, Frederick William. Catalogo dei Crostacei Italiani e di Molti Altri del Mediterraueo. [8vo, 48 pages, 1 plate.] Naples, 1851.

Huxley, Thomas Henry. A Manual of the anatomy of invertebrated animals. [8vo. 698 pages.] London, 1877. American edition [12mo. 596 pages], New York, 1878.

Johnston, George. Contributions to the British Fauna. <The Ediuburgh Philoeophical Journal, vol. xiii, pp. 218-222, 1825.

Johnston, George. Illustrations in British Zoology. <Loudon's Magazine of Natural History, vol. viii, pp. 494-498. London, 1835. Ibid., vol. ix, pp. 79-83. 1836.

Jones, John Matthew. Notes on the marine zoology of Nova Scotia. <Proceedings and Transactions of the Nova Seotian Institute of Natural Science of Halifax, N. S., rol. ii, 1869-70, part ir, pp.93-99. Halifax, 1870.

Jones, Thomas Rupert. Mannal of the natural history of Greenland. See Luitken, Christian Friedrich.

Kinahan, John Robert. Analysis of certain allied genera of terrestrial Isopoda ; with description of a now genus and a detailed list of the British species of Ligia, Philougria, Philoscia, Porcellio, Oniscus and Armadillidium. < Natural History Review, 1857, Proceedings of Societies, pp. 258-282, pl. xix-xxii. Dublin, 1857. 
Kingsley, John Sterling. Bulletin of the Essex Institute, vol, ix, pp. 103-108. Seo Streets, Thomas Hale.

Kingsley, John Sterling. Notes on New England Isopoda, [by O. Harger, Notice of.] <American Naturalist, vol.xiv, pp. 120-121. Philadelphia, 1880.

Kirby, William, and Spence, William. "An Introluction to Entomology, or Eloments of the natural history of Insects. 5th and 6th editions. London."

Kröyer, Henrik. Grönlands Amfiporler. <Kongolige Dansko Videnskabenes Selskabs naturvidenskabeligo og mathematiske Afhaullinger, vol. vii, pp. 229-326, (1-93) pl. i-iv. Copenhagen, 1838.

Kröyer, Henrik. Mumna, en ny lírobsilyrslıgt. <Naturbistorisk Tidsskrift, Bind ii, pl. 61:-616, pl. vi, figs. 1-9. Copenhagen, 1839.

Kröyer, Henrik. Nyo Arter af Slagten Tanais. <Naturhistorisk Tidsskrift, Bind iv, pp. 167-168, pl. ii. Copenhagen, 1842.

Kröyer, Henrik. Monografisk Fremstilling af Slregten Hippolyte's nordiske Arter. $<$ Kongelige Danske Videuskabenes Selskabs naturvidenskabolige og mathematiske Af handlinger, vol. ix, pp. 211-360, pl. i-vi. Copenhagen, 1842.

Kröyer, Henrik. Kareinologiske Bidrag. <Naturhistorisk Tidsskrift, II, Bind ii, pp. 1-123, 1846, and pp. 366-446, 1847. Copenhagen, 1846-7.

Kröyer, Henrik. Voyages on Scaudinavie en Laponie, au Spitzberg et aux Fóröe, Zoologie, Crustacés. (Publiées sous la direction de M. Paul Gaimard). [40 folio plates.] Paris, 1849.

Lamarck, Jean P. B. A. de M. de. Histoire naturelle les animaux sans vertebres. $2^{\text {me }}$ Edit. Revue et augment6e de notes par MM. G. P. Deshayes et H. Milne Edwards.

Latreille, Pierre Andre. Histoire naturelle génerale et partieulière des Crustacés et des Insectes. [8 vo, 14 vols. text, 1 vol. plates.] Paris, An x-xiii (1802-1805).

Iatreille, Pierre Andre. Genera Crustaceorum et Instetorum secundum ordinem naturalem in familias disposita, iconibus exemplisque plurimis explicata. [2 vols., 16 plates.] Paris, 1806-1807.

Latreille, Pierre Andre. *ntomologie ou histoire naturelle des Crustacés, des Arachnides et les Insectes. < Encyelopédie méthodique. Paris, 1789-1825."

Latreille, Pierre Andre. Le Règne Auimal distribue d' après son Organisation par M. Lo Baron Cuvier, tome iv, Crustacés, Arachnides et partie des Insectes. [8ro, 584 pages.] Paris, 1829.

Latreille, Pierre Andre. Cours d'Entomologie, ou de l'Histoire naturelle des Crustacés des Arachnides, des Myriapodes et des Insectes. [8vo, 568 pages, with atlas of 24 plates.] Paris, 1831.

Latrobe, Benjamin Henry. A drawing and deseription of the Clupea tyrannus and Onisens prigustator. < Transactions of the American Philosophical Society, vol. v, pp. 77-81, pl.i. Philadelphia, 1802.

Leach, William Elford. Crustaceology. < Edinburgh Encyclopædia, vol, vii. Ediuburgh, "1813-14."

I have seen only an Anerican edition, in which the article is on pp. 221-27\%.

Leach, William Elford. A tabular view of the external characters of four classes of animals which Linne arranged under Insecta; with the distribntion of the genera eomposing three of theso classes into orders, etc., and descriptions of several new genera and species. <Transactions of the Linnean Society of London, vol. xi, pp. 306-400. London, 1815. 
Ieach, William Elford. Cymothoadées. <Dictionnaire des Ściences naturelles, tome xii, pp. 338-354. Paris, 1818.

Leidy, Joseph. Contributions toward a knowledge of the marine invertebrate fauna of the coasts of Rhode Island and New Jersey. < Journal of the Academy of Natural Science, II, vol. iii, pp. 135-152, pl. x-xi. Philadelphia, 1855.

Leidy, Joseph. Notices of some animals on the coast of New Jersey. < Proceedings of the Academy of Natural Sciences of Philadelphia, 1879, pp. 198-199. 1879.

Lenz, Heinrich. Die wirbellosen Thiere der Travemünder Bucht. Theil I=Anhang I zu dem Jahresberichte 1874-1875 der Kommission zur wissenschaftlichen Untersuchung der deutschen Mecre in Kiel. [24 pages, 2 plates.] Berlin, 1878.

Lereboullet, Auguste. Annales des Sciences naturelles, Zoologie, II, tome xv, pp. 17\%-240. See Duvernoy, George Louis.

Lilljeborg, Wilhelm. Bidrag till den högnordiska hafsfaunan. < Cfversigt af Kongl. Vetenskaps-Akademiens Förhandlingar, Arg vii, pp. 82-88. Stockholm, 1850.

Lilljeborg, Wilhelm. Norges Crustacéer. < Efversigt af Kongl. VetenskapsAkademiens Förhandlingar, Ärg viii, pp. 19-25. Stockholm, 1851.

Lilljeborg, Wilhelm. Hafs-Crustaceer vid Kullaberg. < Efversigt af Kongl. Vetenskaps-Akademiens Förhandliugar, Åg ix, pp. 1-13. Stockholm, 1852.

Lilljeborg, Wilhelm. Bidrag till kännedomen om de inom Sverige och Norrige förekommande Crustaceer af Isopodernas underordning och Tanaldernas familj. [8vo, 32 pages.] Upsala, 1865.

Linné, Carl von. "Fauna Snecica, sistens animalia Sneciæ Regni Quadrupedia, Avos, Amphibia, Pisces, Insecta, Vermes, distributa per classes ot ordines, genera ot species. Editio altera, 8vo. Stockholm, 1761."

Linné, Carl von. Systema Naturæ per Regna tria Naturæ, secundum classes, ordines, genera, species cum characteribus, differentiis, synonymis, locis. Tomus I, Ed. 12 reformata. Holmiae (Stockholm), 1766-1767.

Lockington, William Neale. Description of seventeen new species of Crustacea. $<$ Proceedings of the California Academy of Sciences, vol. vii, pp. 41-48 (1-8). Sau Francisco, 1877.

Lucas, Hippolyte. Histoire naturelle des animaux articulés. Crustacés. [pp. 1-88, 8 plates.] < Exploration Scientifique de l'Algérie pendant les années, 1840-1842. Sciences physiques, Zoologie, I. Paris, 1849.

Iütken, Christian Friedrich. Nogle Bemærkninger om de nordiske સEga-arter samt om Aga-slagtens rette Begriendsning. <Videnskabelige Meddelelser fra den naturhistoriske Forening i Kjübenhavn, Aaret 1858, pp. 65-78, pl. 1 A. 1859.

Lïtken, Christian Friedrich. Om visse Cymothoagtige Krebsdyrs Ophold i Mundhuleu hos forskjellige Fiske. < Videnskabelige Meddelelser fra den naturhistoriske Forening i Kjöbenhavn, Aaret 1858, pp. 172-179. Copenhagen, 1859.

Lütken, Christian Friedrich. Tillæg til ,Nogle Bemærkninger om de nordiske Ega-arter samt om Ega-slagtens rette Begræudsning "-Om Ega tridens Leach og Aiga rotundicanda Lilljeborg samt om slægterue Acherusia og Egacylla. $<$ Videnskabelige Meddelelser fra den naturhistoriske Forening i Kjöbenhavn, Aaret 1860, pp. 175-183 (1-9). Copenlagen, 1861.

Liitken, Christian Friedrich. Ibid., 1861, pp.274-276. See Steenstrup, Japetus. 
Liitken, Christian Friedrich. The Crustacea of Grecnland. < Manual of the natural history, geology and physies of Greenland and the noighbouring regions; prepared for the use of the Aretie expedition of 1875 , by T. Rupert Jones, pp. 146-165. London, 1875.

Macdonald, John Denis. On the external anatomy of Tanais vittatus occurring with Limnoria and Chelura terebrans in exeavated pier-wood. < Transactions of tho Linnean Society, II, Zoology, vol. i, pp. 67-71, pl. xv. London, 1875.

M'Intosh, William Carmichael. On the invertebrate marine fauna and fishes of St. Andrews. <Amnals and Magazine of Natural History, IV, vol. xiii, pp. 140-145, 204221, 302-315, 342-357, 420-432, vol. xiv, pp. 68-75, 144-155, 192-207, 258-27.4, 337-349, 412-4:5. London, 1874 .

Marcusen, Johann. Zur Fauna des schwarzen Meeres. <Archiv für Naturgoschichte, Jahrgang xxxiii, Band i, pp. 357-363. Berlin, 186\%.

Mayer, Paul. Carcinologische Mittheilungen. VI. Ueber den Hermaphroditismus bei einigen Isopoden. < Mittheilnngen aus der Zoologischen Station zu Neapel: B. i, pp. 165-179, pl. v. Leipzig, 1879.

Meinert, Fr. Crustacea Isopoda, Amphipoda ot Decapoda Daniæ: Fortegnelse over Danmarks Isopode, Amphipode, og Decapode Krebsdyr. "Naturhistorisk Tidsskrift, III," pp. 57-248. Copenhagen, "1877."

Metzger, Adolf. Die wirbellosen Meeresthiere der ostfriesischen Küste. Ein Beitrag zur Fauna der deutschen Nordsee. < Zwanzigster Jahresbericht der naturhistorischen Gesellschaft zu Hannover, pp. 22-36. Hannover, 1871.

Metzger, Adolf. Nordseefahrt der Pommerania-" Zoologische Ergebnisse der Nordseefahrt, X. Crustaceen aus den Ordnungen Edriophthalmata u. Podophthalmata, taf. vi. Aus Jahrsbericht der Commission $\mathrm{zu}$ wiss. Untersuchung des deutsches Meer, im Kiel, Jahre 1872-1873." Berlin, 1875.

Miers, Edward John. List of the species of Crustacea collected by the Rev. A. E. Eaton at Spitzbergen in the summer of 1873 , with their localities and notes. < Annals and Magazine of Natural History, IV, vol. xix, pp. 131-140. London, 1877.

Miers, Edward John. Report on the Crustacea collected by the naturalists of the Arctic Expedition in 1875-1876. < Annals and Magnzine of Natural History, IV, vol. $\mathrm{xx}, \mathrm{pp} .52-66$ and $96-110, \mathrm{pl}$. iii-iv. London, 1877.

Milne-Edwards. See Edwards, Alphonse Milne and Henri Milne.

Möbius, Karl. Die wirbellosen Thiere der Ostsce. < "Bericht ïber dio Expedition zur physikalisch-chemischen und biologisehen Untersuchung der Ostsee im Sommer 1871 auf S. M. Avisodanipfer Pommerania." pp. 97-144. Kiel, 1873.

Möbius, Karl. On the invertebrate animals of the Baltic. < Annals and Magazine of Natural History, IV, vol. xii, pp. 81-89. London, 1873.

Translated by IV. S. Dallas from the preceding.

Mohr, Nicholas. Fors $\phi g$ til en Islandisk Naturhistorie, med adskillige œkonomiske samt andre Anmærkninger. [8vo, 413 pages.] Copenhagen, 1786.

Montagu, George. Description of several marine animals found on the south coast of Deronshire. < Transactions of the Linnean Society of London, vol. vii, pp. 61-85, tab. vi-vii, 1804. Ibidl., vol. ix, pp. 81-114, tab. ii-viii. 1808.

Montagu, George. Descriptions of several new or rare animals, principally marine, discovered on the south coast of Devonshire. < Transactions of the Linnean Society of London, vol. xi, pp. 1-26, tab. i-v. London, 1815.

Moore, Edward. On the occurrence of Teredo navalis and Limnoria terebrans in Plymouth Harbour. < Magazine of Natural History, new series, vol. ii, pp. 206210. London, 1838. 
Moore, Edward. Limnoria terebrans in Plymouth Harbour. <Magazine of Natural History, now series, vol, iii, pp. 196-197. London, 1839.

Moore, Edward. Catalogue of the malacostracous Crustacea of South Devon. <Magazine of Natural History, new series, vol. iii, pp. 234-294. London, 1839.

Moseley, Henry Nottidge. Remarks on observations by Capt. Hutton, Director of the Otago Museum, on Peripatus nova-zealandix, with notes on the structuro of the species. < Amals and Magazine of Natural History, IV, vol. xix, 1p. 85-91. Loudon, 1877.

Moseley, Henry Nottidge. Hermaphroditism in tho parasitic Isopoda. Further remarks on Mr. Bullar's papers on the above subject. < Annals and Magazine of Natural History IV, vol.xix, pp. 310,311. London, $187 \%$.

Müller, Friedrich. Bemorkungen zu Zaddach's Synopseos Crustaceorum Borussicorum prodromus. < Archiv für Naturgeschichte, Jahrgang, xiv, Band i, pp. 62-64, pl. iv. Berlin, 1848.

Müller, Friedrich [Fritz]. Ueber den Ban rler Scheerenasseln (Asellotes hétéropodes M. Edw.). < Archiv fïr Naturgeschichte, Jahrg. xxx, B. i, pp. 1-6. Berlin, 1864.

Miiller, Friedrich [Fritz]. Facts and Arguments for Darwin. Translated by W.S. Dallas. [8vo., 144 pages.] London, 1869.

Müller, Friedrich [Fritz]. Bruchstücke für Naturgeschichte der Bopyriden. < Jenaische Zeitschrift für Medicin ụnd Naturwissenschaft, Band vi, pp. 53-73, taf. iii-iv. Leipzig, 1871.

Münter, Julius, and Buchholz, Reinhold. " Ueber Balanus improvisns (Darw.) var. gryphicns (Mïnter). Beitrag zur carcinologischen Fauna Deutschlands. <Mittheilungeu d. naturwissensch. Vereins von Neu-Vorpommern u. Rügen, i, pp. 1-40, 2 plates. Berlin, 1869."

Norman, Alfred Merle. Reports of deep-sea dredging on the coast of Northumberland and Durham, 1862-64. Report on the Crustacea. < Natural History Transactions, Northumberland and Durham, vol. i, pp. 12-29, "1865."

Norman, Alfred Merle. Report of the committeo appointed for the purpose of exploring the coasts of the Hebrides by means of the dredge. Part ii, on the Crustacea, Echinodermata, Polyzoa, Actinozoa and Hydrozoc. < Report of the British Association for the Advancement of Science for 1866, Reports on the State of Science, pp. 193-206. London, 186\%.

Norman, Alfred Merle. Preliminary report on the Crustacea, Molluscoida, Echinodermata, and Cœlenterata, procured by the Shetland dredging committee in 1867. $<$ Report of the British Association for the Advancement of Science for 1867, Reports on the State of Science, pp. 437-441. Loudon, 1868.

Norman, Alfred Merle. On two Isopods belonging to the genera Cirolana and Anilocra, new to the British Islands. <Annals and Magazine of Natural History, IV, vol. ii, pp. 421-422, pl. xxiii. London, 1868.

Norman, Alfred Merle. Last Report on drolging among tho Shetland Isles, Part ii, Crustacea, ete. < Report of the British Association for the Advancement of Science for 1868, Reports on the State of Science, pp. 247-336 and 344-345. Londou, 1869.

Norman, Alfred Merle. Crustacca, Tunicata, Polyzoa, Echinodermata, Actinozoa, Foraminifera, Polycistina, and S̄pongida in "Preliminary Report of the Biological Results of a Cruise in H. M. S. "Valorous' to Davis Strait in 1875." By J. Gwyn Jeffreys. < Proccedings of the Royal Society, vol. $x x \nabla, \mathrm{pp} .202-215$. London, 1876. 
Grsted, Auders Sandöe. Beretning om en Excursion til Trindelen, en Alluvialdannelse i Odensef jord, i Esteraaret 1811, d. 19do Octbr. < Naturbistorisk Tidsskrift, Bind iii, pp. 552-569, tab. viii. Copenhagen, 1841.

Owen, Richard. "The Zoology of Captain Becchey's Voyage " " " to the Pacifie Ocean and Behring's Straits, performed in 11. M. Ship Blossom " " * in the years 18:5-23." Crustacea, pp. 77-92, pl. xxiv-xxviii. London, "1839."

Packard, Alpheus Spring. A list of animals dredged near Caribou Island, Southeru Labrador, during Jnly and Angust, 1860. < Canadian Naturalist and Geologist, vol. viii, pp. 401-429, pl, i-ii. Montreal, 1863.

Packard, Alpheus Spring. Observations on the glacial phenomena of Labrador and Maine, with a view of the recent invertebrate fanna of Labrador. < Memoirs of the Boston Socicty of Natural History, vol. i, pp. 210-303, pl. vii-viii. Boston, 1867.

Packard, Alpheus Spring. On the Crustaceans and Insects [in] The Mammoth Cave and its inhabitants, by the editors. < American Naturalist, vol, v, pp. 744761. Salem, 1871.

Packard, Alpheus Spring. On the cave fauna of Indiana. < Fifth Annual Report of the Trustees of the Peabody Academy of Science, pp. 93-97. Salem, 1873.

Panceri, Paolo. Mem. Accad. Sci. Torino, II, vol.xix,pp. 85-118. See Cornalla, Emilio.

Parfitt, Edward. The fauna of Devon. Part IX. Sessile-eyed Crustacea. [8vo, 25 pages.] "Repriuted from the Transactions of the Devonshiro Association for the Advancement of Science, Literature, and Art. 1873."

Pennant, Thomas. "The British Zoology, 4th Edit., 4 vols., with 279 plates, 4 to. London, 17\%7."

Pidgeon, Edward. The Classes Crustacea, etc. See Griffith, Edward.

Rathke, Heinrich. "Beitrag zur Fanna der Krimm. < Memoiren der kaiserlichen Akademie der Wissensehaften zu St. Peterslsurg, Theil iii, pp. 291-454, 773-774. 1837."

Rathke, Heinrich. Beiträge znr Fauna Norwegens. < Nova Acta Academiæ Cæsareæ Leopoldino-Carolinæ Naturæ Curiosorum, tom. xx, pp. 1-264c., taf, i-xii. Breslau and Bonn, 1843.

Rathke, Jens. "Jagttagelser henhorende til Indvoldsormenes og Blöddyrenes naturhistorie; med anmärkningar af 0 . Fabricius. < Skrivter af naturhistorieSelskabet, vol. v, pp. 61-153, tab. ii-iii. Copenhagen, 1799."

Reinhardt, Johann T. Fortegnelse over Gronlands Krebsdyr, Annelider og Indvoldsorme. <Naturhistorisk Bidrag til en Beskrivelse af Grфnland, pp. 28-49. " Særrskilt Aftryk af Tillægene til 'Gr $\phi$ nland, geographisk og statistisk beskrevnet' af H. Rink." Copenhagen, 1857.

Risso, Antoine. Histoire naturelle des Crustacés des environs de Nice. [8vo, 176 pages, 3 plates.] Paris, 1816.

Risso, Antoine. " "Histoire naturelle de l'Europe méridionale, tome v. Paris, 1826."

Ritzema Bos, Jan. See Bos, Jan Ritzema.

Roux, Jean Louis Florent Polydore. "Crustacés de la Méditerranée et de son Littoral décrits et lithographies. Marseilles, 18:9-1830." 
Saenger, Nicholas. "Preliminary acconnt of an exploration of the fauna of the Baltic. <Communications of the Imp. Society of Nat. Sc. Anthropol. and Ethnol. of the Univers. of Moscow, vol. viii, pp. 22-34. 1869."

Samouelle, George. The Entomologist's useful Compendium; or an introduction to the knowledge of British Insects. [8vo, 496 pp., 12 plates.] London, 1819.

Sars, George Ossian. [Om en anomal Gruppe af Isopoder.] <Forhandlinger i Videnskabs-Selskabet i Christiania, Aar 1863, pp. 205-221. Christiana, 1864.

Sars, George Ossian. Beretning om en i Sommeren, 1865, foretagen Zoologisk Reise ved Kysterne af Christianias og Christiansands Stifter. [8vo, 47 pages.] < "Nyt Magazin for Naturvidenskaberne." Christiania, 1866.

Sars, George Ossian. Histoire naturelle des Crustacés d'ean donce de Norvège. $1^{\text {me }}$ livraison. Les Malacostracés. [4to, 145 pages, 10 plates.] Christiania, 1867.

Sars, George Ossian. Unders $\phi$ gelser over Christianiafjordens Dybvandsfauna anstillede paa en i Sommeren 1868 foretagen zoologisk Reise. [8vo, 58 pages.] < "Nyt Magazin for Naturvidenskaberne." Christiania, 1869.

Sars, George Ossian. Undersфgelser over Hardangerfjordens Fanna. <Forhandlinger i Videnskabs-Selskabet i Christiania, Aar 1871, pp. 246-286. Christiania, 1872.

Sars, George Ossian. Bidrag til Kundskaben om Dyrelivet paa vore Havbanker. < Forhandlinger i Videnskabs-Selskabet i Christiania, Aar 1872, pp. 73-119. Christiania, 1873.

Sars, George Ossian. Prodromus descriptionis Crustaceorum et Pjcuogonidarnm, quae in expeditione Norvegica Anno 1876, observavit G. O. Sars. < Archir for Mathematik og Naturvidenskab, Bind ii, pp. 337* [237]-271. Christiania, 1877.

Sars, Michael. Oversigt over de i den norsk-arctiske Region forekommende Krebsdyr. < Forhandlinger i Videnskabs-Selskabet i Christiania, Aar 1858, pp. 122163. Christiania, 1859.

Sars, Michael. [Beskrivelse af en ny Slægt og Art af Isopoder: Minnopsis typica Sars. ] CForhandlinger i Videnskabs-Selskabet i Christiania, Aar 1860, pp. 84-85. Christiania, 1861.

Sars, Michael. Bidrag til Kundskab om Christianiafjordens Fauna. [104 pages, 7 plates.] < "Nyt Magazin for Natnrvidenskaberne." Christiania, 1868.

Sars, Michael. Fortsatte Bemærkninger over det dyriske Livs Udbrednŭng i Havets Dybder. < Forhandlinger i Videnskabs-Selskabet i Christiania, Aar 1868, pp. 246275. Christiania, 1869.

Savigny, Jules Cæsar. Description de l'Égspte ou Recueil des Observations et des Recherches pendant l'Expedition de l'Armée Francaise. Histoire naturelle, Planches, Zoologie, Crustacés. [13 folio plates.] Paris, 1817.

Say, Thomas. An account of the Crustacea of the United States. < Journal of the Academy of Natural Science, vol. i, part i, pp. 57-63, 65-80, pl. iv, pp. 97-101, 155169, 181 ; part ii, pp. 235-253, 313-319, 374-401, 423-441. Philadelphia, 1817-1818.

Say, Thomas. Observations on some of the animals described in the accont of the Crustacea of the United States. < Journal of the Academy of Natural Science, vol. i, part ii, pn. 442-444. Philadelphia, 1818.

*In this volume the paging from 200 to 268 is incorrectly printed $300-368$. The separata are paged 337-371. 
Schiödte, Jörgen C. On the structuro of tho month in sucking Crustacea, parti, Cymothow. < Annals and Magazine of Natural History, IV, vol.i, pp. 1-25, pl. i, 1868. -Parts ii, Anthnra, iii, Laphystius. < Ibid., vol. xriii, pp. 253-266 and 295305. London, 187\%.

Translated from "Naturhistorisk Tidsskrift III, vol. iv with 2 plates, and vol: $x$ with 5 plates. Copenhagen, 1866 and 1875."

Schiödte, Jörgen C. Sur la propagation et les metamorphoses des Crustacés suceurs de la famille des Cymothoadiens. < Comptes Rendus, tome lxxxvii, pp. 52-55. Paris, 1878.

Translated in Annals and Magazine of Natural History, V, rol. ii, pp. 195-197. London, 1878.

Smith, Sidney Irving. This Report, part i, pp.537-747. See Verrill, Addison E.

Smith, Sidney Irving and Harger, Oscar. Report on the dredgings in the region of St. George's Banks in 1872. < Transactions of the Connecticut Academy of Arts and Sciences, vol. iii, part i, pl. 1-57, pl. i-viii. New Haven, 1874 .

Smith, Sidney Irving. The Crustacea of the fresh waters of the United States. <This Report, part ii, pp. 637-665, pl. i-iii. Washington, 1874. [Descriptions of Asellus and of Asellopsis by O. Harger].

Smith, Sidney Irving. The stalk-eyed Crustaceans of the Atlantic coast of North America north of Cape Cod. <'Transactions of the Connecticut Academy, vol. v, pp. 27-136, pl. viii-xii. New Haven, 1879.

Smith, Sidney Irving. Proc. U. S. Nat. Mus., 1879, vol. ii, pp. 157, 158. See Harger, Oscar.

Smith, Sidney Irving. Occurrence of Chelura terebrans, a Crustacean destructive to the timber of submarine structures, on the coast of the United States. < Proceedings of the United States National Museum, 1879, rol. ii, pp. 232-235. Washington, 1880.

Stalio, Luigi. Catalogo Metodico e Descrittivo dei Crostacei Podottalmi ed Edriottalmi dell'Adriatico. [8ro, 274 pages. ] ' '(Estr. dal vol. iii, serie v, degli Atti dell' Instituto Stesso.)" Venice, $187 \%$.

Sowerby, James. The British Miscellany: or coloured figures of new, rare, or little known animal subjects; many not before ascertained to be inhabitants of the British Isles. [2 vols. in one, 8vo, 76 plates.] London, 1804-1806.

Stebbing, Thomas Roscoe Rede. A Sphæromid from Australia, and Arcturidæ from Sonth Africa. < $\Lambda$ nnals aud Magazine of Natural History, IV, vol. xii, pp. 95-98, pl. iii A. London, 1873.

Stebbing, Thomas Roscoe Rede. On a new species of Areturus (A. damnoniensis). <Annals and Magazine of Natural History, IV, vol. xiii, pp. 291-292, pl. xv. London, $18 \% 4$.

Stebbing, Thomas Roscoe Rede. A new Australian Sphromid, Cyclura venosa; and notes on Dsnamene rubra and viridis. < Journal of the Linnean Society, Zoology, vol. xii, pl. 146-151, pl. vi-vii. London, 1874.

Stebbing, Thomas Roscoe Rede. The sessile-ejed Crustacea of Devon. [8vo, 10 pages, 1 plate.] "Reprinted from the Transactions of the Devonshire Association for the Adrancement of Science, Literature, and Art. 1874."

Stebbing, Thomas Roscoe Rede. On some new exotic sessile-ejed Crustaceans. <Annals and Magazine of Natural History, IV, vol. xv, pp. 184-188, pl. xv A. London, 1875. 
Stebbing, Thomas Roscoe Rede. Description of a new species of sessile-ejed Crustacean and other notices. <Annals and Magazine of Natural History, IV, vol. xvii, pp. 73-80, $\mathrm{p}^{\circ}$ iv-v. London, 1876.

Stebbing, Thomas Roscoe Rede. Notes on sessile-eyed Crustacenns with description of a new species. <Annals and Magazine of Natural History, V, vol i, pp. 31-37, pl. v. London, 1878.

Stebbing, Thomas Roscoe Rede. Sessile-eyed Crustacea of Devonshire. Supplementary list. [8ro, 9 pages.] "Reprinter from the Transactions of the Devonshire Association for the Advancement of Science, Literature, and Art." 1879.

Steenstrup, Japetus, and Lïtken, Christian Friedrich. Mindre Meddelelser fra Kjöbenhavns Universitets zoologiske Museum.-2. Forelöbig Notits om dlanske Hav-Krebsdyr. <Videnskabelige Meddelelser fra den Naturhistoriske Forening i Kjöbenhavn, 1861, II, vol. iii, pp. 274-276. Copenhagen, 1862.

Stimpson, William. Synopsis of the Marine Invertebrata of Grand Manan; or the region about the mouth of the Bay of Fundy, New Brunswick. [4to, 66 pp., 3 plates.] <Smithsonian Contributions to Knowledge, vol. vi. Washington, 1853.

Stimpson, William. Deseriptions of some new marine Invertebrata. By William Stimpson, Zoologist to the U. S. Surveying Expedition to the North Pacific, Japan Seas, et.c., under direction of Commander C. Ringgold, U. S. N. <Proceedings of the Academy of Natural Science, vol. vii, 1855, pp. 385-394. Philadelphia, 1855.

Stimpson, William. On an oceanic Isopod found near the southeastern shores of Massachusetts. <Proceedings of the Academy of Natural Science, vol. xiv, 1862, pp. 133-134. Philadelphia, 1862.

Stimpson, William. Synopsis of the marine Invertebrata collected by the late Arctic Expedition under Dr. I. I. Hayes. <Proceedings of the Academy of Natural Science, vol. xv, 1863, pp. 138-142. Philadelphia, 1863.

Streets, Thomas Hale, and Kingsley, John Sterling. An examination of types of some recently described Crustacea. <Bulletin of the Essex Institute, vol. ix, pp. 103-108. Salem, 18\%7.

Templeton, Robert. Description of a minute crustaceous animal from the Island of Mauritius. <Transactions of the Entomological Society, vol. ii, pp. 203-207, pl. xviii. London, "1836."

Templeton, Robert. Catalogue of Irish Crustacea Myriapoda and Arachnöidea, selected from the papers of the late John Templeton, Esq. < Loudon's Magazine of Natural History, vol. ix, pp. 9-14. London, 1836.

Thompson, William. On the Teredo navalis and Limnoria terebrans as at present existing in certain localities on the coasts of the British Islands. < Edinburgh Now Philosophical Journal, vol. xviii, pp. 121-130. 1835.

Thompson, William. Note on the Teredo norvegica, Xylophaga dorsalis, Limnoria terebrans and Chelura terebrans combined in destroying the submerged wood-work at the Harbor of Ardrossan, on the coast of Ayrshire. < Annals and Magazine of Natural History, vol. xx, pp. 157-164. London, 1847.

Thompson, William. Additions to the fauna of Ireland, Crustacea. <Annals and Magazine of Natural History, vol. xx, pp. 23\%-250. London, 1847.

Van Beneden, Pierre Joseph. Recherches sur la Faune littorale de Belgique. Crustacés. [4to, 180 pages, 32 plates.] "Extrait du tome xxxiii des Ḿ́moires do l'Académie royale de Belgique." Bruxelles, 1861. 
Verrill, Addison Emory. On the distribution of marine animals on the southern coast of New England. < American Journal of Science and Arts, III, vol. ii, pp. 357-362. New Haven, 1871.

Verrill, Addison Emory. Results of recent dredging expeditions on the coast of New England. (No. 1). <American Journal of Science and Arts, III, vol. v, pp. 1-16, Jan. 1873.-(No. 2). < Llbid., pp. 98-106, Feb. 1873.-No. 3. < Ibid., vol. vi, pp. 435-441, Dec. 1873.-No. 4. <Ibid., vol, vii, pp. 38-46, Jan. 1874.-No. 5. <Ibid., pp. 131-138, Feb. 1874.-No. 6. < Ibid.,pp. 405-414,pl. iv-v, Apr., 1874.No. 7. < Ibil., pp. 498-505, pl. vi-viii, May, 18т4. New Haven, 1873-4.

Verrill, Addison Emory. Explorations of Casco Bay by the United States Fish Commission in 1873. < Proceedings of the American Association for the Advance. ment of Science, Portland Meeting, 1873, pp. 340-395, pl. i-vi. Salem, 1874.

Verrill, Addison Emory. Report upon the invertebrato animals of Vineyard Sound and the adjacent waters, with an account of the physical characters of the region. <This Report, part i, pp. 295-778 (1-478), pl. i-xxxviii. Washington, 1874.

Published also separately with the above title or, Invertebrata of Southern New England, by A. E. Verrill and S. I. Smith. [8vo, 478 pages, 38 plates.] Washington, 1874.

Verrill, Addison Emory, Smith, Sidney Irving, and Harger, Oscar. Catalogne of the marine invertebrate animals of the Southern Coast of New England and adjacent waters. < This Report, part i, pp. 537-747 (243-453), pl. i-xxxviii. Washington, 1874.

Published also as a part of the above Report upon the invertebrate animals of Vineyard Sound and adjacent waters or Invertebrata of Southern New England, by A. E. Verrill and S. I. Smith, pp. 243-453. Washington, 1874.

Verrill, Addison Emory. Results of dredging expeditions off the New England Coast in 1874. < American Journal of Science and Arts, III, vol. ix, pp. 411-415, vol. $x$, pp. 36-43, pl. iii-iv, and pp. 196-202. New Haven, 1875.

Wagner, Nicholas. Recherches sur le système circulatoire et les organes de respiration chez le Porcellion 6largi (Porcellio dilatatus Branclt). < Annales des Sciences naturelles, Zoologie, V, tome iv, pp. 317-328, pl. xiv B. Paris, 1865.

Wagner, Nicholas. Observations sur l'organisation et le développement des Ancees. $<$ Bulletin de l'Acadómie Impériale des Sciences de St. Pótersbourg, tome x, pp. 497-502. 1866.

Westwood, John Obadiah. Extrait des recherches sur les Crustacés du genre Pranize de Leach. < Annales des Sciences naturelles, tome xxvii, pp. 316-322, pl. vi. Paris, 1832.

Westwood, John Obadiah. British Sessile-eyed Crustacea. See Bate, C. Spence.

White, Adam. List of the specimens of Crustacea in the collection of the British Mruseum. [143 pages.] London, 1847.

White, Adam. List of the specimens of British animals in the collection of the British Museum, part iv, Crustacca. [141 pages.] London, 1850.

White, Adam. A popular history of British Crustacea, comprising a familiar acconnt of their classification and habits. [358 pages, 20 plates.] London, 1857.

Whiteaves, Joseph Frederick. Notes on a dcep-sea dredging-expedition round the Island of Anticosti, in the Gulf of St. Lawrence. ' < Annals and Magazine of Natural History, IV, vol. x, pp. 341-354. London, 1872. 
Whiteaves, Joseph Frederick. Report of a second deep-sea dredging expedition [in 1872] to the Gulf of St. Lawrence, with some remarks on marine fisheries of the Province of Quebec. [8vo, 22 pages.] Montreal, 1873.

Whiteaves, Joseph Frederick. On recent deep-sea dredging operations in the Gulf of St. Lawrence. < American Journal of Science and Arts, III, vol. vii, pp. 210 219. New Haven, 1874.

Whiteaves, Joseph Frederick. Report on further deep-sea dredging operations in the Gulf of St. Lawrence [in 1873], with notes on the present condition of the marine fisheries and oyster-beds of part of that region. [8vo, 29 pages.] "Ottawa, 1874."

Willemoes-Suhm, Rudolf von. Von der Challenger Expedition. Briefe an C. Th. E. v. Siebold. II, Sidney, im April, 1874. < Zeitschrift für wissenschaftliche Zoologie, Band xxiv, pp. ix-xxiii. Leipzig, 1874.

Willemoes-Suhm, Rudolf von. On some Atlantic Crustacea from the 'Challenger' Expedition. < Transactions of the Linnean Society of London, II, Zoology, vol. i, pp. 23-59, pl. vi-xiii. London, 1875.

Willemoes-Suhm, Rudolf von. Preliminary report to Professor Wyville Thomson, F. R. S. Director of the civilian scientific staff, on observations made during the earlier part of the voyage of H. M. S. 'Challenger.' <Proceedings of the Royal Society, vol. xxiv, pp. 569-585.--On Crustacea observed during the cruise of $\mathrm{H}$. M. S. 'Challenger' in the Southern Sea. <Tom. cit., pp. 585-592. London, 1876.

Woodward, Henry. Crustacea. <Encyclopædia Britannica, 9th edition, vol. vi, pp. 632-666. Edinburgh and Boston, 1877.

Zaddach, Ernęst Gustav. Synopseos Crustaceorum Prussicorum Prodromus. [4to, 39 pages.] Regiomonti (Königsberg), "1844." 


\section{TABLE OF CONTENTS.}

XIV.-Report on the Marine Isopoda of New England and adjacent waters, by

Oscar Harger............................................. 297

Isopoda ...................................................... 297

Synoptical table of families ................................. 304

Oniscidø .............................................. 305

Bopyridæ ........................................... 311

Asellidæ .............................................. 312

Munnopsidø ......................................... 328

Idoteidæ............................................ 335

Arcturidæx .......................................... 361

Sphæromidæ ....................................... 367

Limnoriidæs ........................................ 371

Cirolanidæ........................................... 376

Egidæ................................................. 382

Cymothoidæ ........................................... 390

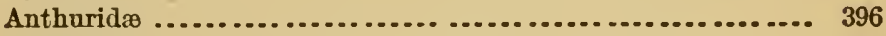

Gnathiidæ .......................................... 408

Tanaidw ........................................... 413

Geographical distribution ................................. 428

List of authorities............................................. 436

Table of contents ............................................ 451

Explanation of the plates ...................................... 453

Alphabetical index ............................................ 459 



\section{EXPLANATION OF THE PLATES.}

\section{PLATE I.}

Frgori 1.-Philoscia vittata Say (p. 306); dorsal viow, enlarged six diameters; natural size indicated by cross at the right.

2.-Scyphacella arenicola Smith (p. 307); dorsal view, enlarged about twelve diameters; natural sizo indicated by cross at the right.

3.-Actoniscus ellipticus Harger (p. 309); dorsal view, enlarged ten diameters; natural size indicated by line at the right.

4.-Jæra albifrons Leach (p. 315); female; dorsal view, enlarged about ten diameters.

5.-The same; maxilliped from the left side, exterior view, enlarged twentyfive diameters; $\mathrm{P}$, palpus; $l$, external lamella.

6.-The same; maxillæ, enlarged twenty-five diamoters; $a$, outer, or second, pair of maxillw; $b$, inner, or first, pair of maxillø; $i$, inner, $e$, outer lobe.

7.-The same; inferior surface of the pleon of a female.

8.-The same; inferior surface of the pleon of a male.

(All the figures were drawn from nature by 0 . Harger.)

\section{PLATE II.}

Figure 9.-Janira alta Harger (p. 321); dorsal view, enlarged five diameters; natural size indicated by line at the right.

10.-Janira spinosa Harger (p.323); dorsal view of female, enlarged six diameters.

11.-Munnopsis typica M. Sars (p. 330); dorsal view of male, enlarged about two diameters; $b$, maxillipeds; $m$, basal segment; $l$, external lamella; 2 and 3 , secoud and third segments of palpus of maxillipeds; $c$, onter maxilla; $d$, inner maxill $x$; $e$, one of the second pair of legs of the male; $f$, one of the natatory legs; $g$, abdominal operculum of the female, external view.

(Figures 9 and 10 were drawn from nature by O. Harger; figuro $\mathbf{1 1}$ is copied from M. Sars, drawn by G. O. Sars.)

\section{PLATE III.}

FIGURE 12.-Janira alta (p. 321); $a$, maxilliped; P, palpus of maxilliped; $l$, external lamella; $b$, mandible; $P$, palpus of mandible; $d$, dentigerous lamella; $m$, molar process, enlarged twenty-five diameters.

13.-The same; inferior surface of the pleon, $a$ in the female, $b$ in the male, enlarged ten diameters; $a$, single opercular plate in the femalo; $b$, external ; $c$, median plate of operculum of male.

14.-Munna Fabricii Kröyer (p. 325); female; dorsal viow, enlarged about trenty diameters; natural size indicated by line at the right.

15.-Eurycope robusta Harger (p. 332); female; dorsal view, enlarged six diameters; natural size indicated by line at the right; $a$, antennula, enlarged twenty diameters; $b$, maxilliped; $c$, mandible; $d$, one of the first pair of legs, each enlarged twenty diameters; $d^{\prime}$, propodus and dactylus of the first pair of legs, enlarged about thirty-eight diameters; e, propodus and dactylus of the second pair of legs, enlarged twenty 
diameters; $f$, one of the sixth pair of legs; $g$, uropod, each enlarged twenty diameters.

(Figure 14 was drawn from nature by Mr. J. H. Emerton, the others by O. Harger.)

\section{PLATE IV.}

Figure 16.-Chiridotea cœea Harger (p. 338); dorsal view, enlarged nearly four diameters; natural size indicated by the line at the right.

17. -The same; $a$, antennula ; $b$, antenna ; each enlarged twelve diameters.

18.-The same; $a$, maxilliped from the right side, external view; $l$, external lamella; $m$, maxilliped proper; $1,2,3$, first, second, and third segments of the palpus of the maxilliped, enlarged twenty diameters; $b$, one of the first pair of legs, magnified twelve diameters; $c$, uropod from the left side, inuer view, showing the two rami articulated near the tip.

19. -The same; pleopods of second pair from the right side, anterior views, enlarged ten diameters; $a$, common form in males; $b$, rarer form in male; 8 , elongated stylet, articulated near the base of the inner lamella; c, form in the female.

20.-Chiridotea Tuftsii Harger (p. 340); female; dorsal view, enlarged five diameters; natural size indicated by the line at the right.

21.-The same; left maxilliped, enlarged twenty-five diameters; $e$, external lamella; $m$, basal segment; $1,2,3$, segments of palpus.

22.-The same; pleopod of the second pair, from a male, enlarged twenty diameters; 8 , elongated stylet, articulated near the base of the inner lamella.

(All the figares were drawn from nature by O. Harger.)

\section{PLATE V.}

Frgure 23.-Chiridotea Tuftsii Harger (p. 340); $a$, an tennula ; $b$, antenna ; $c$, leg of the first pair; $d$, leg of the fourth pair; all enlarged twelve diameters; e, left uropod, or opercular valve, inner view, enlarged ten diameters.

24.-Idotea irrorata Edwards (p. 343); dorsal view, eularged two diameters; natural size shown by the line on the left.

25.-The same; $a$, antennula ; $b$, antenna ; $c$, left uropod or opercular valve, external view; all enlarged six diameters.

26.-The same; $a$, right maxilliped, enlarged twelve diameters, $l$, external lamella; $m$, basal segment; $1,2,3,4$, segments of palpus of maxilliped; $b$, pleopod of the second pair from a male, enlarged eight diameters, showing stylet, 8, articulated near the base of the inner lamella.

27.-Idotea phosphorea Harger (p. 347); dorsal view, enlarged about two diameters; natmral size shown by the line on the right.

28.-The same; $a$, antenua, enlarged six diameters; $b$, maxilliped, enlarged twelve diameters, showing, $l$, external lamella; $m$, basal segments; 1,2 , 3,4 , segments of the palpus of maxilliped ; $c$, leg of the first pair; $d$, leg of the second pair, both enlarged six diameters; $e$, right uropod, or opercular valve, inner view, enlarged six diameters.

29.-The same; pleopod of the second pair from a male, enlarged eight diameters; 8 , stylet articulated near the base of the inner lamella; $\boldsymbol{8}^{\prime}$, distal ond of stylet reversed and enlarged thirty diameters.

(Figure 24 was drawn by Mr. J. H. Emerton, the others by O. Harger.)

\section{PLATE VI.}

Figure 30.-Idotea robusta Kröyer (p. 349); dorsal view, enlarged two diameters; natural size shown by the line at the right.

31.-The same; $a$, antenua; $b$, leg of the first pair, each enlarged six diameters; $c$, left uropod, or opercular valve, inner viow, enlarged four diameters. 
FIGURE 32.-The same; $a$, maxilliped, enlarged twelve diameters; $l$, external lamella; $1,2,3,4$, segments of palpus; $b$, maxilla of the outer or second pair; $c$, pleopod of the seeond pair from a male, enlarged six diameters; 8 , stylet articulated near the base of the inner lamella.

33.-Synidletea nodulosa Harger (p. 351); dorsal view, enlarged four diameters; natural size indieated by the line at the right.

34.-The same; $a$, antemmula $f$, flagellar segment; $b$, antenna ; $c$, leg of the first pair from the right side; $d$, right mopod, or opercular valve, all enlarged ten diameters.

35.-The same; a, maxilliped from the right sicle, showing, l, external lamella; $m$, hasal segment; $1,2,3$, segments of palpus, enlarged twenty diumeters; $b$, maxilla of the outer or second pair; $c$, maxilla of the inner or first pair, both enlarged twenty diameters; $d$, pleopod of the second pair from a male, enlarged twelve diameters; $s$, stylet articulated near the base of the inner lamella.

36.-Erichsonia atteunata Harger (1. 356); dorsal view, enlarged three diameters, natural size indicated by the line at the right.

(Figures 30 and 36 were drawn by Mr. J. H. Emerton, the others by O. Harger.)

\section{PLATE VII.}

FIgURE 37.-Erichsonia attenuata Harger (p. 356); $a$, antennula ; $b$, antenna, each enlarged twelve diameters; $c$, maxilliped, showing, $l$, external lamella, enlarged thirty diameters; $d$, uropod, or opercular valve, enlarged twelve diameters; $e$, pleopod of the second pair from a male, enlarged fifteen diameters; $s$, stylet, articulated near the base of the inner lamella; $s^{\prime}$, distal end of stylet, enlarged fifty diameters.

38.-Erichsonia filiformis Harger (p. 355); dorsal view, enlarged fivo diameters, natural size indicated by the line at the right.

39.-The same; $a$, antennula ; $b$, antenna ; $c$, leg of the first pair; $d$, nropod, or opercular valve, each enlarged twelve diameters.

40.-The same; $a$, maxilla of onter or second pair; $b$, maxilla of inner or first pair; $c$, mandible, showing molar process, $m$, and dentigerous lamella, $d$, all enlarged thirty diameters.

41.-The same; $a$, maxilliped, showing, l, external lamella; $m$, basal segment, and $1,2,3,4$, segments of palpus, enlarged thirty diameters; $b$, pleopod of the second pair from a male, enlarged fifteen diameters; $s$, stylet, articulated near the base of the inner lamella; $s^{\prime}$, distal end of stylet, enlarged fifty diameters.

42.-Epelys trilobus Smith (1. 358); dorsal view, enlarged ten diameters; natural size indieated by the line at the right.

43.-The same; $a$, maxilliped from the left sille, enlarged twenty diameters; $l$, external lamella; $m$, basal segment; $1,2,3$, segments of palpus of maxilliped; $b$, pleopod of second pair from a male, enlarged twenty diameters; 8 , stylet, articulated near the base of the inner lamella; $\boldsymbol{8}^{\prime}$, end of stylet, enlarged fifty diameters.

(All the figures were drawn from nature by O. Harger.)

\section{PLATE VIII.}

Figure 44.-Epelys montosns Harger (p. 359); dorsal view, enlarged six diameters, natural size indieated by the line at the right.

45.-The same; $a$, antennula; $f$, flagellar segment; $b$, antenna; $c$, maxilliped from tho left side; $l$, external lamella; $m$, basal segment; $1,2,3$, segments of palpus; all the figures enlarged twenty diameters.

46.-The same; $a$, leg of the first pair, enlarged twenty diaureters; $b$, right uropod or opercular valve, enlarged fifteen diameters. 
Fraure 47.-The same; pleopod of the second pair, from a male, enlarged twenty diameters; 8, stylet, artieulated near the base of the inner lamella; $\mathbf{8}^{\prime}$, distal end of stylet, enlarged sixty-six diameters.

48.-Astacilla granulata Harger (p. 364); female; dorsal view, enlarged four diameters, natural size indieated by the line at the right; $a$, antennula of male; $b$, fourth thoraeie segment of male; $c$, inferior surface of pleon of a male, showing opereular valves; all the figures enlarged four diameters.

49.-The same; $a$, flagellum of antenna, enlarged twenty diameters ; $a^{\prime}$, portion of inner margin of the same, enlarged one hundred diameters; $b$, one of the first pair of legs, upper surface, enlarged twenty diameters.

50.-The samo; one of the fourth pair of legs, enlarged twenty diameters.

51.-The same; inner surface of left opercular plate, or uropod, from a female, enlarged twenty diameters.

(All the figures were drawn from nature by O. Harger.)

\section{PLATE IX.}

Figure 52.-Astaeilla gramnlata Harger (p. 364); $a$, maxilliped; $m$, basal segment; $l$, external lamella; $b$, outer maxilla; $c$, inuer maxilla; all enlarged twenty diameters.

53.-Sphæroma quadridentatum Say (p. 368); dorsal view, enlarged five diameters; natural size indicated by the line at the right.

54.-The same; $a$, antennula; $b$, antenna; $c$, pleopod of the second pair, from a male, showing stylet, $s$, artieulated near the base of the inner lamella; all the figures enlarged ten diameters.

55.-Limnoria lignorum White (p. 373); dorsal view, enlarged ten diameters; natural size indieated by the line at the right.

56.-The same; $a$, antennula; $b$, antenna ; $c$, maxilliped; $d$, maxilla of the outer or second pair; $e$, maxilla of the inner or first pair; $f$, mandible, all enlarged twenty-five diameters; $e^{\prime}$, distal end of onter lobe of first pair of maxilla, enlarged sixty-six diameters.

57.-The same; $a$, last segment of pleon, with attached uropods; dorsal view, enlarged ten diameters; $b$, uropod with dotted adjacent outline of last segment of pleon, enlarged thirty diameters; $c$, first pair of pleopods; $d$, pleopod of the second pair, from a male, showing stylet, 8 , articnlated to the inner lamella; both figures enlarged twenty diameters.

58.-Cirolana coneharum Harger, (p. 378); lateral view, enlarged about three diameters.

(Figure 53 was drawn by Mr. J. H. Emerton, 55 by Prof. S. I. Smith, 58 by Mr. J. H. Blake, and the others by O. Harger.)

\section{PLATE X.}

Figure 59.-Cirolana eoneharum Harger (p. 378); dorsal view, enlarged about threo diameters. The natural size is shown by the line at the right.

60.-The same; antennula, enlarged ten diameters.

61.-The same; $a$, antenna enlarged ten diameters; $b$, maxilla of the outer or second pair; $c$, maxilla of the inner or first pair; $d$, mandible from the right side, inner view ; $p$, palpus; $m$, molar area; the last three figures enlarged five diameters.

62.-The same; $a$, maxilliped from the right side, exterior view, showing, $l$, external lamella; $m$, basal segment; $1,2,3,4,5$, segments of the palpus; $b$, leg of the fourth pair; both the figures enlarged five diameters.

63.-The same; uropod from the right side; inferior view, enlarged five diameters.

64. - Zga psora Kröyer (p. 384); $a$, dorsal and $b$ ventral views of a young individual. . The central line.indicates the length of the specimen, natural 
size, which is hero enlarged three diameters. Adults attain about the size of the figure.

Frgure 65.-Nerocila munda Harger (p. 392); dorsal view of the type specimen, enlarged about four diameters. The natural sizo is shown by the cross on the right; $a$, uropod, onlarged six diamoters.

66. - EEgathoa loliginea Harger (p. 393); typo specimen; $a$, dorsal, and $b$, ventral viow, enlarged four diameters. Its natural size is shown by the line between the figures.

(Figure 59 was drawn by Mr. J. H. Blake, the others by O. Harger.)

\section{PLATE X I.}

FrguRe 67.-Livoneca ovalis White (p. 395); $a$, antennula; $b$, antenna ; $c$, mandibular palpus; each enlarged twenty diameters; $d$, one of tho first pair of legs; $e$, ono of the seventh pair of legs; $f$, uropod; each enlarged ten diameters.

68.-Anthura polita Stimpson (p. 398); dorsal vicw, enlarged four diameters. The natural size is shown by the line at the right; $a$, antennula; $b$, antenna, each enlarged ten diameters; $c$, leg of the first pair; $d$, leg of the third pair; $e$, right pleopod of the first pair, interior view, showing inner ramus without cilia; $f$, pleopod of the second pair from a male, showing stylet articulated to inner lamella; each of the figures $c$ to $f$ onlarged eight diameters; $g$, lateral view of pleon, enlarged six diameters.

69. -The same; $a$, maxilliped, enlarged twenty diameters; $b$, maxilla, enlarged twenty-five diameters; $b^{\prime}$, distal end of the same, enlarged sixty diameters.

70.-Paranthura brachiata Harger (p. 402); dorsal view, enlarged about three diameters; natural size shown by the line at the right; $a$, antennula; $b$, antenna, enlarged eight diameters; $c$, right maxilliped, enlarged sixteen diameters; $d$, maxilla, enlarged sixtcen diameters; $d^{\prime}$, distal end of the same, enlarged fifty diameters; $e$, leg of the first pair; $f$, first pleopod from the right side, inner view, showing ciliated inner lamella; $g$, pleopod of the second pair from a male, showing stylet articulated to the inner lamella; figures $e$ to $g$ enlarged eight diameters.

71.-Ptilanthura tenuis Harger (p. 406); male; dorsal view, enlarged about four diameters; $a$, inferior view of the head and first thoracic segment, enlarged eight diameters; the flagellum of the antennula omitted; $b$, maxilliped ; $c$, maxilla, each enlarged fifty diameters; $d$, first right pleopod, seen from within, showing ciliated inner lamella; $e$, second left pleopod, showing stylet 8 articulated to the inner lamella in the males.

72.-The same; one of the first pair of legs of a male, enlarged sixteen diameters.

73.-The same; female; dorsal view of the head, enlarged twenty-five diameters.

(Figure 71, excepting $b-d$, was drawn by Mr. J. H. Emertou, the others by O. Harger.)

\section{PLATE XII.}

FIgURE 74.-Ptilanthura tenuis Harger (p. 406); $a$, antennula; $b$, antenna; cach enlarged twenty diameters, from a male.

75.-Gnathia cerina Harger (p. 410); male; dorsal view, enlarged ten diameters.

76.-The same; $a$, antennula; $b$, antenna, each enlarged thirty-eight diameters; $c$, mandibles ( $l$, left, $r$, right), enlarged thirty-eight diameters; $d$, first leg or first gnathopod from the right side, enlarged twenty-five diameters; all the figures from the malo sex.

77.-The same (p. 411); female; dorsal view, enlarged ten diameters. 
Figure 78.-The same; $a$, one of the first pair of legs or first gnathopod of a female, enlarged thirty-eight diameters; $b$, one of the first pair of legs in a young, parasitic individual, enlarged sixty diameters; c, pleon, with the last and part of the penultimate thoracic segments of a female, dorsal view, eularged twenty diameters; $d$, pleopod of a young, parisitic individual, enlarged sixty diameters; $e$, pleopod of an adult male, enlarged sixty diameters.

79.-The same; young male; dorsal view, enlarged twenty diameters.

80.-Leptochelia algieola Harger (1. 421); male; lateral view, enlarged twenty diameters; natural size indicated by the lino above.

(All the figures were drawn from nature by O. Harger.)

\section{PLATE XIII.}

Frgure 81.-Tanais vittatus Lilljeborg (p. 418); dorsal vier, enlarged eight diameters. The transverso bands of hairs on the pleon are not sufficiently distinct.

82.-The same; one of the first pair of pleopods, enlarged thirty diameters.

83.-Leptochelia algicola ITarger (p. 421); female; dorsal view, enlarged twenty diameters; natural size inclieated by the line at the right.

84. -The same; $c$, antennula; $b$, one of the first pair of legs; both from a female specimen and enlarged twenty-five diameters.

85.-The same; hand, or propodus and daetylus of the first pair of legs, enlarged forty-eight diameters, showing the comb of setw on the propodus.

86.-The same; uropods of a male, enlarged seventy diameters; $b$, basal segment; $i$, inner six-jointed ramus; $o$, outer ramus.

87.-Leptochelia limicola Harger (p. 424); female; dorsal view, enlarged twenty diameters; natural size shown by the line at the right.

88. -The same; $a$, antennula; $b$, antenna; $c$, leg of the first pair; $d$, leg of the second pair; all from the female sex and enlarged twenty-five diameters.

89.-Leptoehelia rapax Harger (p. 424); male; dorsal view, enlarged about twelve diameters.

90.-The same; hand, or propodus and dactylus of male, eularged sixteen diameters.

91.-Leptoehelia coeca Harger (p. 427); type speeimen, female; $a$, antennula; $b$, leg of the first pair; $c$, uropod; each enlarged fifty diameters.

(All the figures were drawn from nature by 0 . Harger.) 


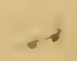




\section{PLATE $I$.}

Figure 1.-Philoscia vittata Say (p. 306); dorsal view, enlarged six diameters; natural size indicated by cross at the right.

2.-Scyphacella arenicola Smith (p. 307); dorsal view, enlarged about twelve diameters; natural size indicated by cross at the right.

3.-Actoniscus ellipticus Harger (p. 309); dorsal view, enlarged ten diameters; natural size indicated by line at the right.

4.-Jæra albifrons Leach (p. 315); female; dorsal view, enlarged about ten diamcters.

5.-The same; maxilliped from the left side, exterior view, enlarged twentyfive diameters; $\mathrm{P}$, palpus; $l$, external lamella.

6.-The same; maxillæ, enlarged twenty-five diameters; $a$, outer, or second, pair of maxillæ; $b$, inner, or first, pair of maxillæ; $i$, iuner, e, outer lobe.

7.-The same; inferior surface of the pleon of a female.

8.-The same; inferior surface of the pleon of a male.

(All the figures were drawn from nature by O. Harger.) 
Fig. 1.

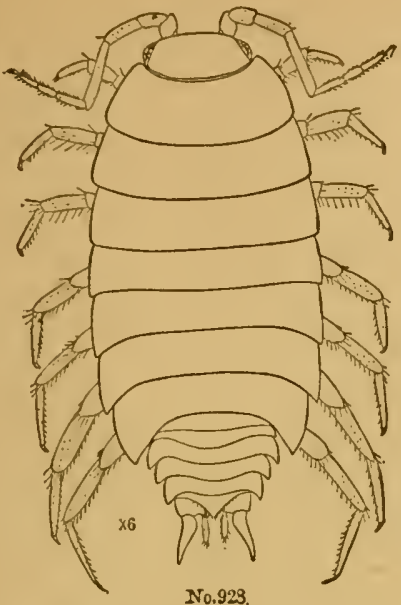

Fiṣ. 5.

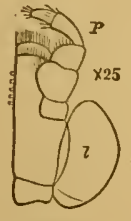

No.921.

Figr. 6.

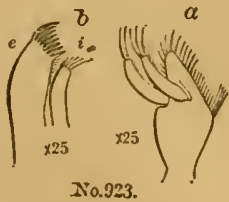

Figr. 2.

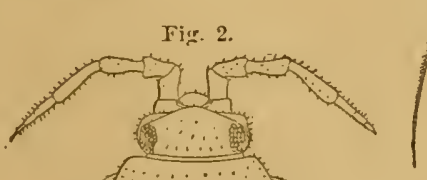

Fig. 7.

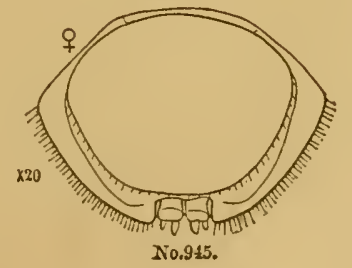

Fig. 3.

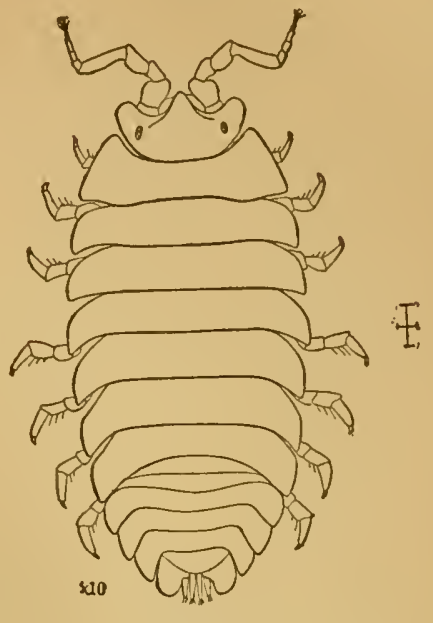

No.929.
Figr. 8.

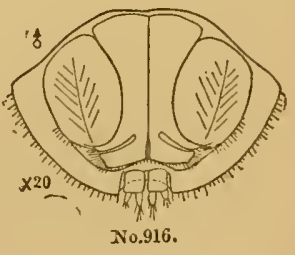

Fig. 4.

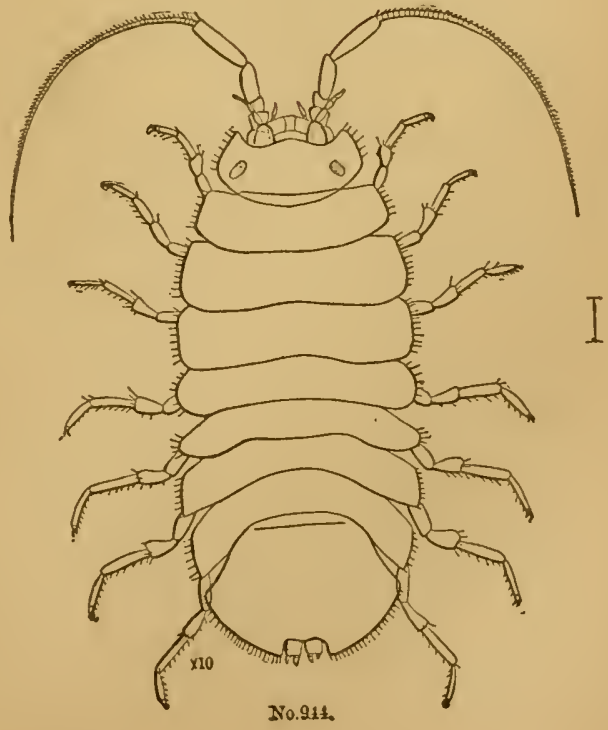





\section{PLATE II.}

FIGURE 9.-Janira alta Harger (p. 321); dorsal view, enlarged five diameters; natural size indicated by line at the right.

10.-Janira spinosa Harger (p.323); dorsal view of female, enlarged six diameters.

11.-Munnopsis typica M. Sars (p. 330); dorsal view of male, enlarged about two diameters; $b$, maxillipeds; $m$, basal segment; $l$, external lamella; 2 and 3 , second and third segments of palpus of maxillipeds; $c$, outer maxillæ; $d$, inner maxillæ; $e$, one of the second pair of legs of the male; $f$, one of the natatory legs; $g$, abdominal operculum of the female, external view.

(Figures 9 and 10 were drawn from nature by 0 . Harger; figure 11 is copied from M. Sars, drawn by G. O. Sars.) 
Fig 10.

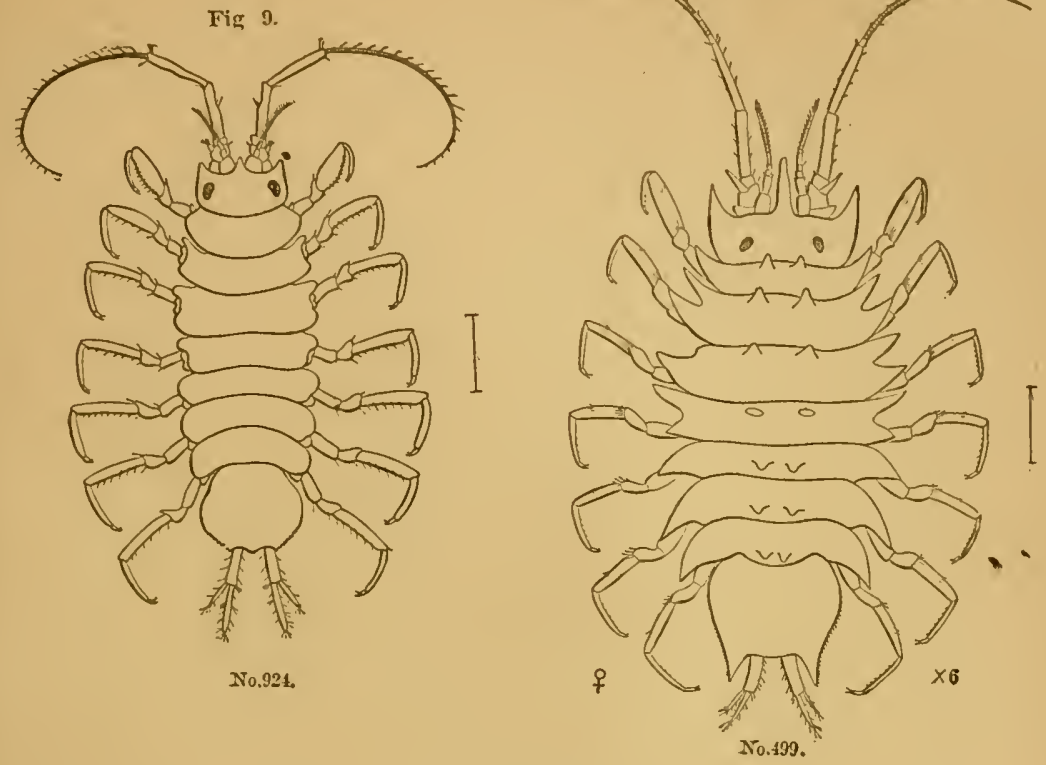

Fig. 11.

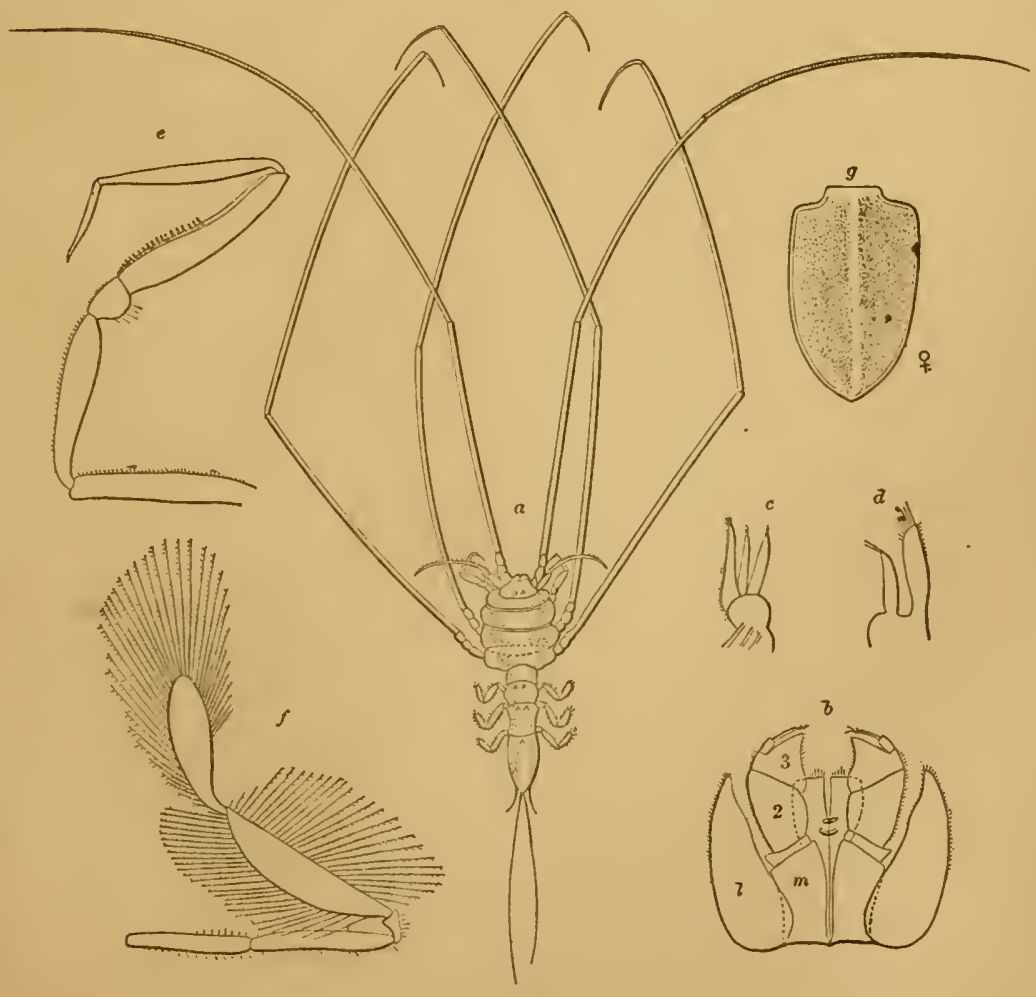





\section{PLATE-III.}

Figure 12.-Janira alta (p. 321); $a$, maxilliped; P, palpus of maxilliped; $l$, external lamella; $b$, mandible; $P$, palpus of mandible; $d$, dentigerous lamella; $m$, molar process, enlarged twenty-five diameters.

13.-The same; inferior surface of the pleon, $a$ in the female, $b$ in the male, enlarged ten diameters; $a$, single opercular plate in the femalo; $b$, external ; $c$, median plate of operculum of male.

14.-Munna Fabricii Kräyer (p. 325); female; dorsal view, enlarged about twenty diameters; natural size indicated by line at the right.

15.-Eurycope robusta Harger (p. 332); female; dorsal view, enlarged six diameters; natural size indicated by line at the right; $a$, antennula, enlarged twonty diameters; $b$, maxilliped; $c$, mandible; $d$, one of the first pair of legs, each enlarged twenty diameters; $d^{\prime}$, propodus and dactylus of the first pair of legs, enlarged about thirty-eight diameters; $e$, propodus and dactylus of the second pair of legs, enlarged twenty diameters; $f$, one of the sixth pair of legs; $g$, uropod, each enlarged twcnty diameters.

(Figure 14 was drawn from nature by Mr. J. H. Emerton, the others by O. Harger.) 
Fig. 12.

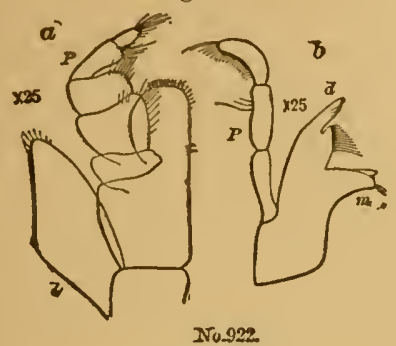

Fig. 13.

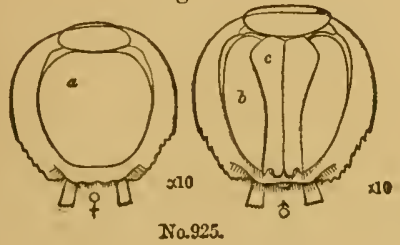

Fig. 14.

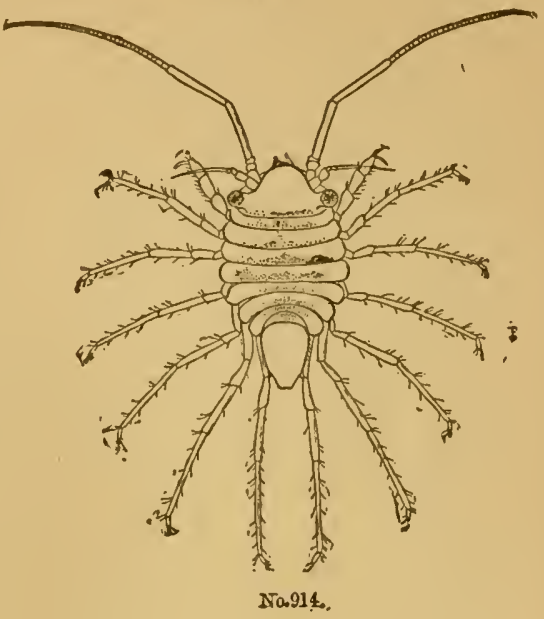

Fig. 15.

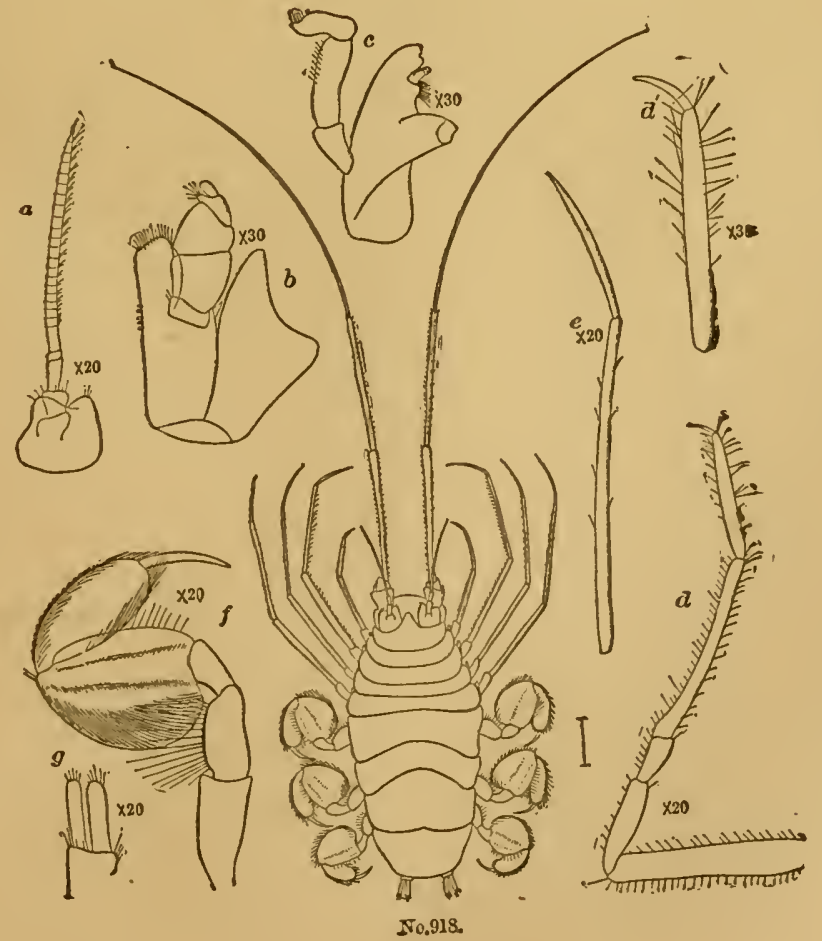






\section{PLATE IV.}

FIGURE 16.-Chiridotea cœea Harger (p. 338); dorsal view, enlarged nearly four diameters; natural size indicated by the line at the right.

17.-The same; $a$, antennula; $b$, antenna ; each enlarged twelve diameters.

18. - The same; $a$, maxilliped from the right side, external view; $l$, external lamella; $m$, maxilliped proper; $1,2,3$, first, second, and third segments of the palpus of the maxilliped, enlarged twenty diameters; $b$, one of the first pair of legs, magnified twelve diameters; e, uropod from the left side, inner view, showing the two rami articulated near the tip.

19. -The same; pleopods of second pair from the right side, anterior views, enlarged ten diameters; $a$, common form in males; $b$, rarer form in male; $s$, elongated stylet, articulated near the base of the inner lamella; $c$, form in the female.

20.-Chiridotea Tuftsii Harger (p. 340); female; dorsæl view, enlarged five diameters; natural size indicated by the line at the right.

21. -The same; left maxilliped, enlarged twenty-five diameters; e, external lamella; $m$, basal segment; $1,2,3$, segments of palpus.

22.-The same; pleopod of the second pair, from a male, enlarged twenty diameters; 8 , elongated stylet, articulated near the base of the inner lamella.

(All the figures were drawn from nature by 0. Harger.) 
Fig. 16.

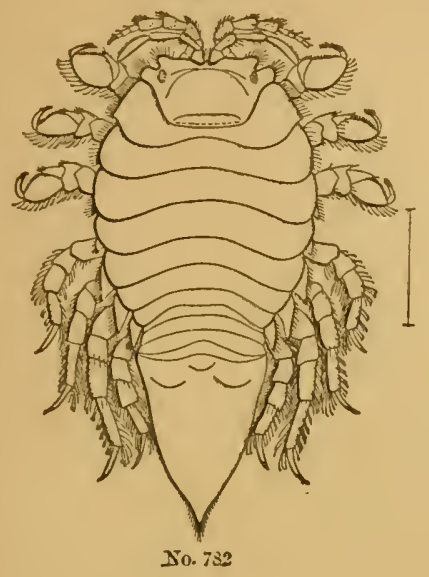

Fig. 19.

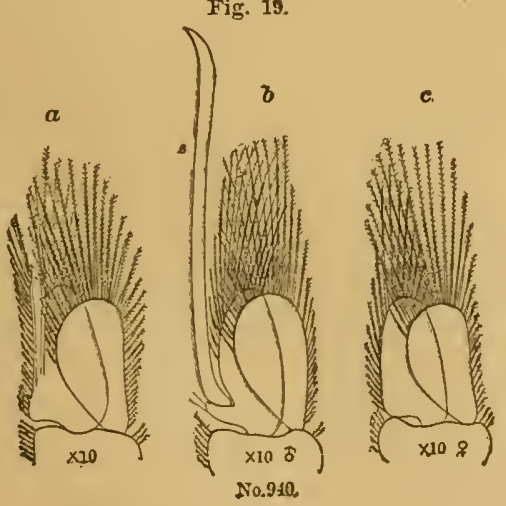

Fig. 18.

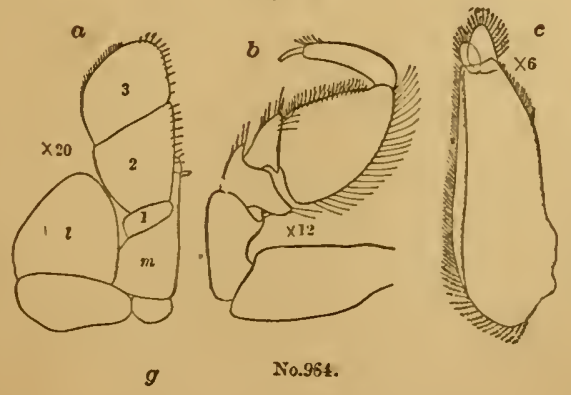

Fig. 22.
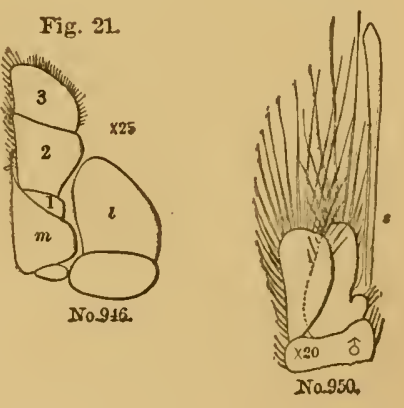

Fig. 17.

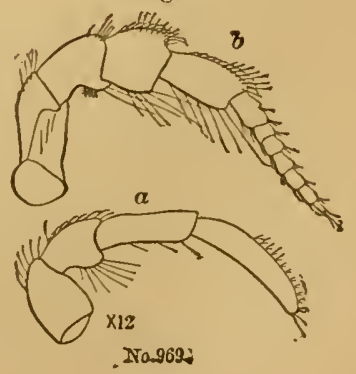





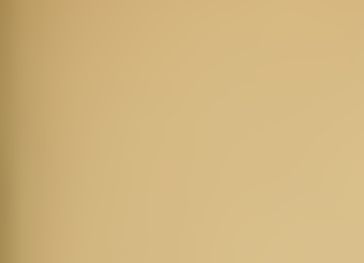

- 


\section{PLATE V.}

Figure 23.-Chiridotea Tuftsii Harger (p. 340); $a$, antennula; $b$, antenna ; c, leg of the first pair; $d$, leg of the fourth pair ; all enlarged twelve diameters; $e$, left uropod, or opercular valve, inner view, enlarged ten diameters.

24.-Idotea irrorata Edwards (p. 343); dorsal view, enlarged two diameters; natural size shown by the line on the left.

25. - The same; $a$, antenuula ; $b$, antenna ; $c$, left uropod or opercular valve, external view; all enlarged six diameters.

26. -The same; $a$, right maxilliped, enlarged twelve diameters, $l$, external lamella; $m$, basal segment; $1,2,3,4$, segments of palpus of maxilliped; $b$, pleopod of the second pair from a male, enlarged eight diameters, showing stylet, s, articulated near the base of the inner lamella.

27.-Idotea phosphorea Harger (p. 347); dorsal view, enlarged about two diameters; natural size shown by the line on the right.

28. -The same; $a$, antenna, enlarged six diameters; $b$, maxilliped, enlarged twelve diameters, showing, $l$, external lamella; $m$, basal segments; 1,2 , 3,4 , segments of the palpus of maxilliped; $c$, leg of the first pair ; $d$, leg of the second pair, both enlarged six diameters; $e$, right uropod, or opercular valve, inner view, enlarged six diameters.

29. -The same; pleopod of the second pair from a male, enlarged eight dianeters; 8 , stylet articulated near the base of the inner lamella; $\boldsymbol{8}^{\prime}$, distal end of stylet reversed and enlarged thirty diameters.

(Figure 24 was drawn by Mr. J. H. Emerton, the others by O. Harger.) 
Fig. 25.

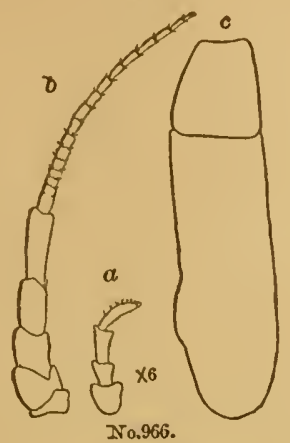

Fig. 26.

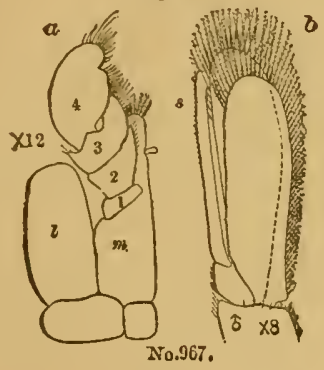

Fig. 28.

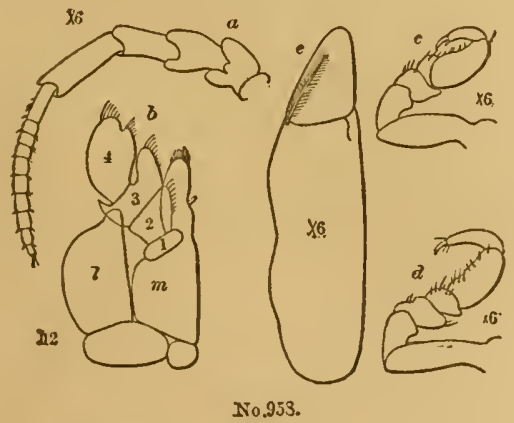

Fig. 29.

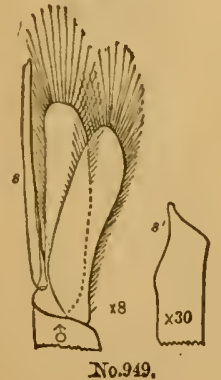

Fig. 24.

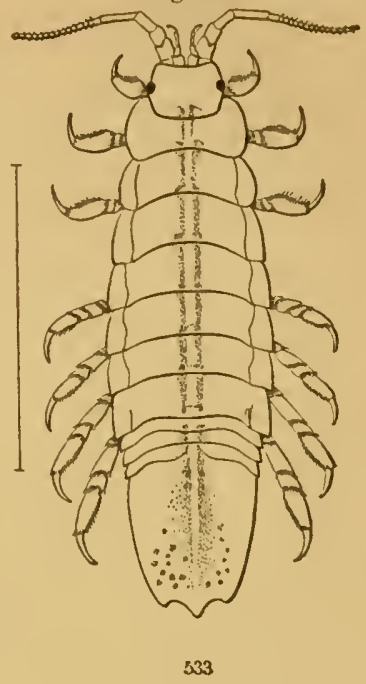

Fig. 27.

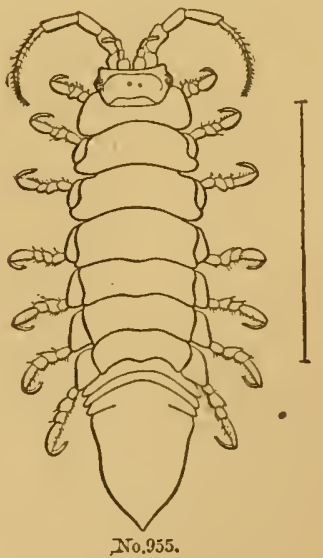

Fig. 23.

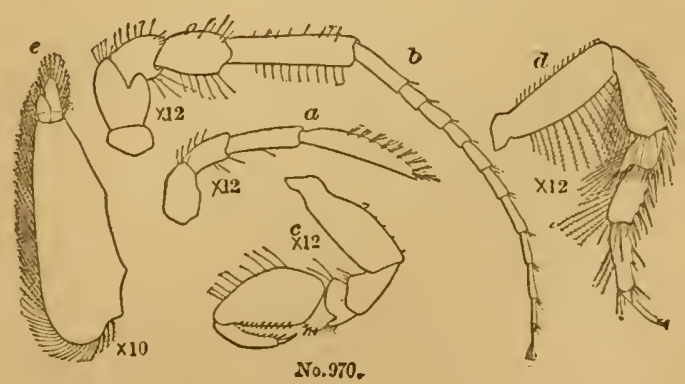





\section{PLATE VI.}

Figure 30.-Idotea robusta Kröyer (p. 349); dorsal view, enlarged two diameters; natural size shown by the line at the right.

31.-The same; $a$, antenna; $b$, leg of the first pair, each enlarged six diameters; $c$, left uropod, or opercular valve, inner view, enlarged four diameters.

Figure 32.-The same; $a$, maxilliped, enlarged twelve diameters ; $l$, external lamella ; $1,2,3,4$, segments of palpus; $b$, maxilla of the outer or second pair; $c$, pleopod of the second pair from a male, enlarged six diameters; $s$, stylet articulated near the base of the inner lamella.

33. - Synidotea nodulosa Harger (p. 351); dorsal view, enlarged four diameters; natural size indicated by the line at the right.

34.-The same; $a$, antennula; $f$, flagellar segment; $b$, antenna ; $c$, leg of the first pair from the right side; $d$, right uropod, or opercular valve, all enlarged ten diameters.

35.-The same; $a$, maxilliped from the right side, showing, $l$, external lamella; $m$, basal segment; 1, 2, 3, segments of palpus, enlarged twenty diameters; $b$, maxilla of the outer or second pair; $c$, maxilla of the inner or first pair, both enlarged twenty diameters; $d$, pleopod of the second pair from a male, enlarged twelve diameters; 8, stylet articulated near the base of the inner lamella.

36. -Erichsonia attenuata Harger (p. 356); dorsal view, enlarged three diameters, natural size indicated by the line at the right.

(Figures 30 and 36 were drawn by Mr. J. H. Emerton, the others by $\mathrm{O}$. Harger.) 
Fig 31.

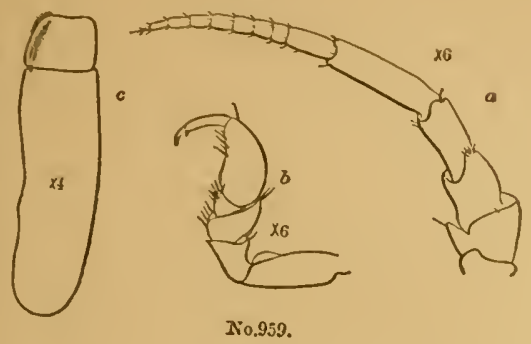

Fig. 32.

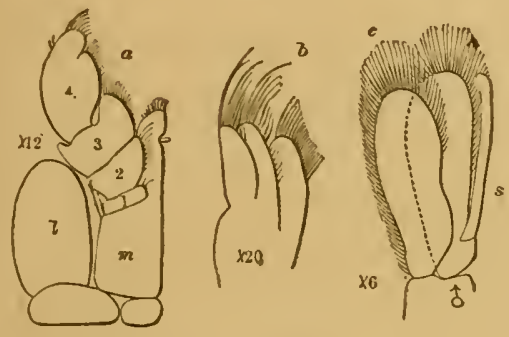

Fig 35 .

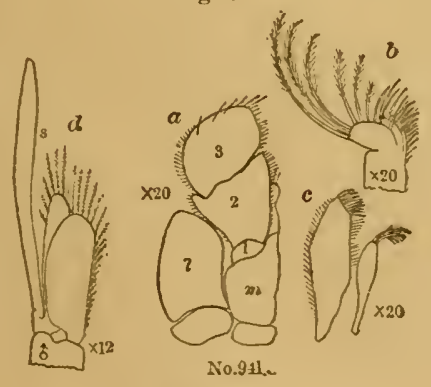

Fig. 36.

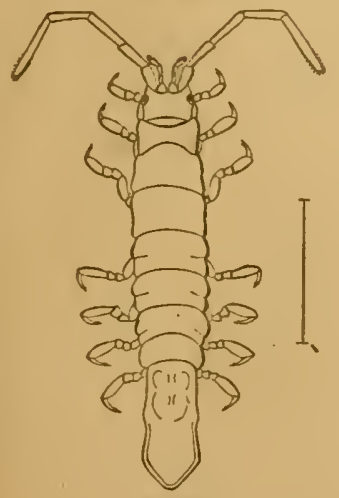

No. 535
Fig. 33.

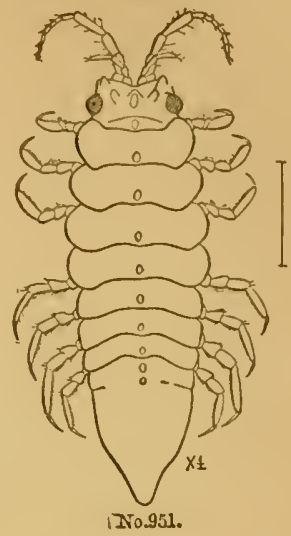

Fig. 34 .

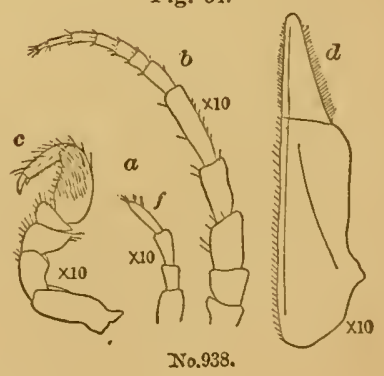

Fig. 30 ,

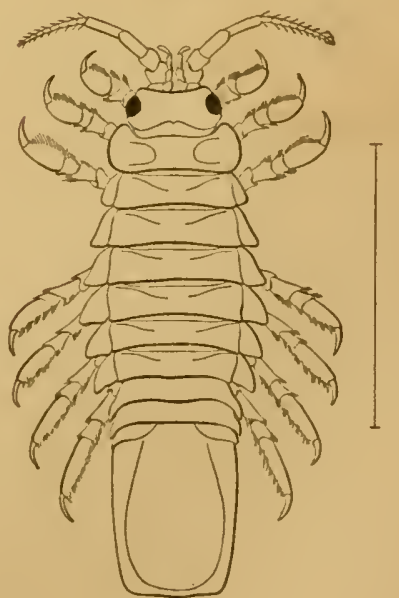






\section{PLATE VII.}

FIGURE 37.-Erichsonia attenuata Harger (p. 356); $a$, antennula; $b$, antenna, each enlarged twelve diameters; $c$, maxilliped, showing, $l$, external lamella, enlarged thirty diameters; $d$, uropod, or opercular valve, enlarged twelve diameters; $e$, pleopod of the second pair from a male, enlarged fifteen diameters; $s$, stylet, articulated near the base of the inner lamella; $s^{\prime}$, distal end of stylet, enlarged fifty diameters.

38.-Erichsonia filiformis Harger (p. 355); dorsal view, enlarged five diameters, natural size indicated by the line at the right.

39.-The same; $a$, antennula ; $b$, antenna ; $c$, leg of the first pair; $d$, uropod, or opercular valve, each enlarged twelve diameters.

40.-The same; $a$, maxilla of outer or second pair; $b$, maxilla of inner or first pair; $c$, mandible, showing molar process, $m$, and dentigerous lamella, $d$, all enlarged thirty diameters.

41.-The same; $a$, maxilliped, showing, $l$, external lamella; $m$, basal segment, and $1,2,3,4$, segments of palpus, enlarged thirty diameters; $b$, pleopod of the second pair from a male, enlarged fifteen diameters ; 8 , stylet, articulated near the base of the inner lamella; $s^{\prime}$, distal end of stylet, enlarged fifty diameters.

42.-Epelys trilobus Smith (p. 358); dorsal view, enlarged ten diameters; natural size indicated by the line at the right.

43. $\rightarrow$ The same; $a$, maxilliped from the left side, enlarged twenty diameters; $l$, external lamella; $m$, basal segment; $1,2,3$, segments of palpus of maxilliped; $b$, pleopod of second pair from a male, enlarged twenty diameters; 8 , stylet, articulated near the base of the inner lamella; $s^{\prime}$, end of stylet, enlarged fifty diameters.

(All the figures were drawn from nature by O. Harger.) 

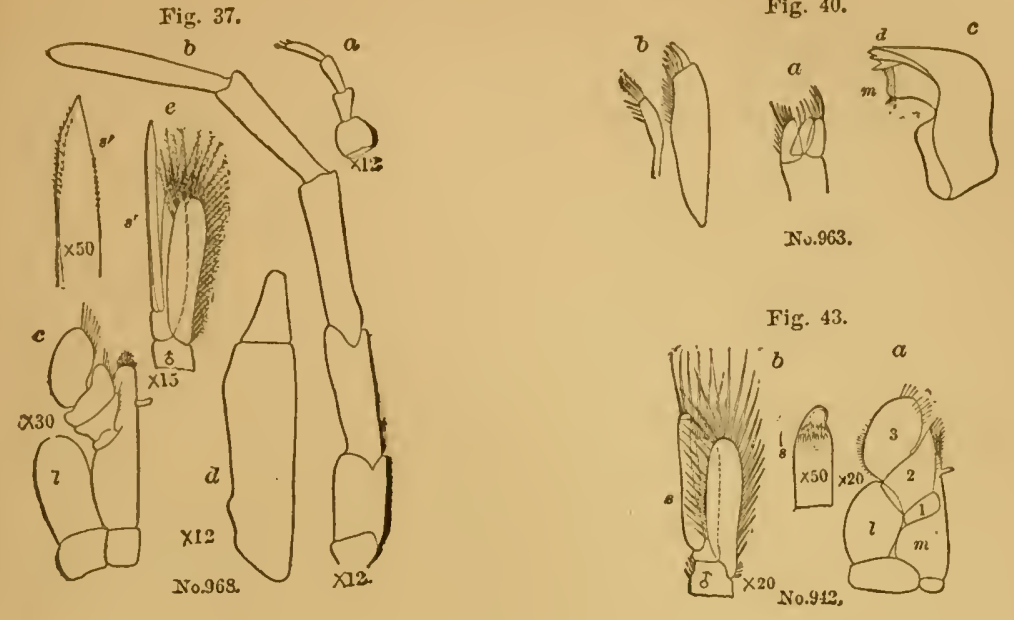

Fig. 40.

Fig. 43.

Fig. 41.
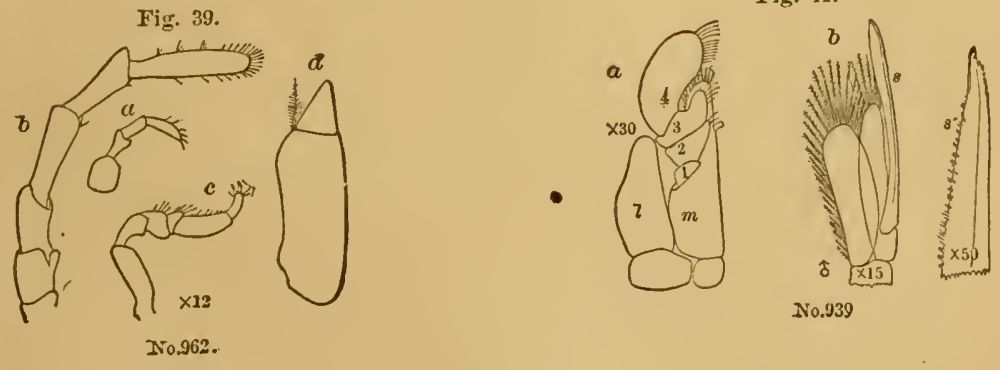

Fig. 42.

Fig. 38 .
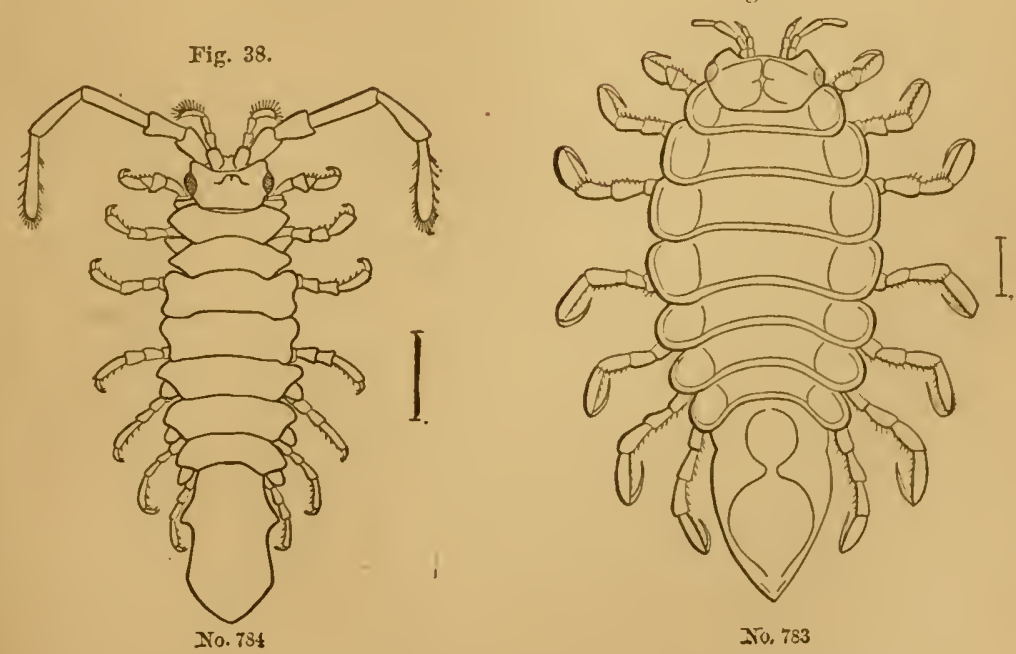



\section{PLATE VIII.}

Frgure 44.-Epelys montosus Harger (p. 359); dorsal view, enlarged six diameters, natural size indicated by the line at the right.

45.-The same; $a$, antennula; $f$, flagellar segment; $b$, antenna; $c$, maxilliped from the left side; $l$, external lamella; $m$, basal segment; $1,2,3$, segments of palpus; all the figures enlarged twenty diameters.

46.-The same; $a$, leg of the first pair, enlarged twenty diameters; $b$, right uropod or operoular valve, enlarged fifteen diameters.

Figure 47.-The same; pleopod of the second pair, from a male, enlarged twenty diameters; s, stylet, articulated near the base of the inner lamella; $\boldsymbol{s}^{\prime}$, distal end of stylet, enlarged sixty-six diameters.

48.-Astacilla granulata Harger (p. 364); female; dorsal view, enlarged four diameters, natural size indicated by the line at the right; $a$, antennula of male; $b$, fourth thoracic segment of male; $c$, inferior surface of pleon of a male, showing opercular valves; all the figures enlarged four diameters.

49.-The same; $a$, flagellum of antenna, enlarged twenty diameters; $a^{\prime}$, portion of inner margin of the same, enlarged one hundred diameters; $b$, one of the first pair of legs, upper surface, enlarged twenty diameters.

50. -The same; one of the fourth pair of legs, enlarged twenty diameters.

51.-The same; inner surface of left opercular plate, or uropod, from a female, enlarged twenty diameters.

(All the figures were drawn from nature by 0 . Harger.) 
Fig, 44.

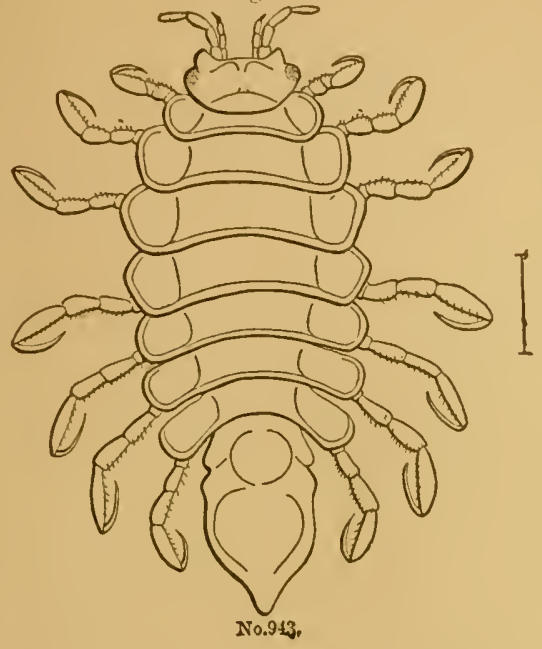

Fig. 49.

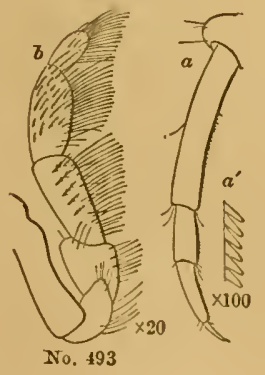

Fig. 50.

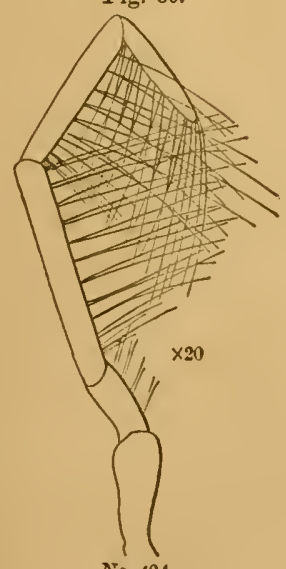

Fig. 47.

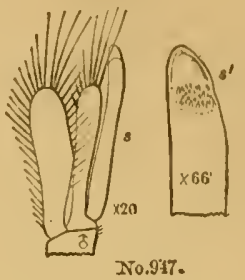

Fig. 45.

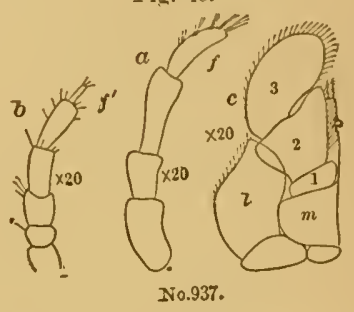

Fig. 46.

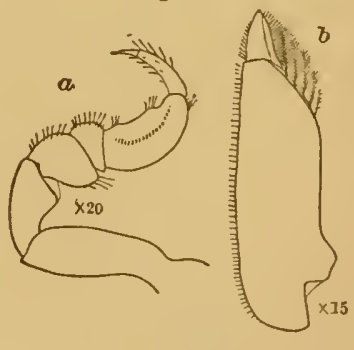

No.965.

Fig. 51.

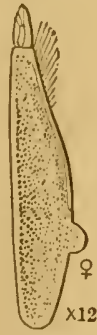

No. 495

Fig. 48.

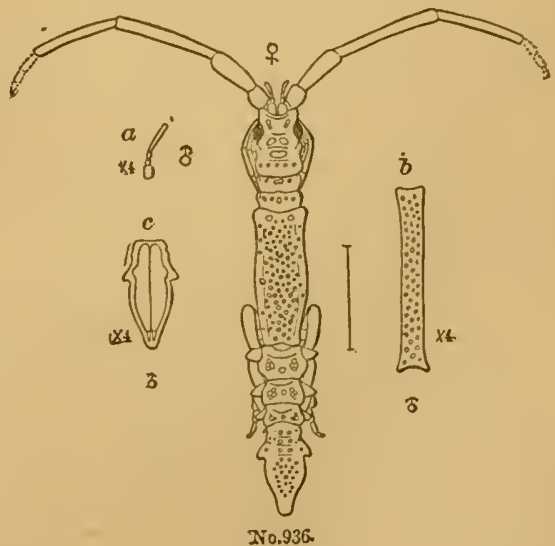





\section{PLATE IX.}

Figure 52.-Astacilla granulata Harger (p. 364); $a$, maxilliped; $m$, basal segment; $l$, external lamella; $b$, onter maxilla; $c$, inner maxilla; all enlarged twenty diameters.

53.-Spheroma quadridentatum Say (p. 368); dorsal view, enlarged five diameters; natural size indicated by the line at the right.

54.-The same; $a$, antennula ; $b$, antenna; $c$, pleopod of the second pair, from a male, showing stylet, 8 , articulated near the base of the inner lamella; all the figures enlarged ten diameters.

55.-Limnoria lignorum White (p. 373); dorsal view, enlarged ten diameters; natural size indicated by the line at the right.

56.-The same; $a$, antennula; $b$, antenna ; $c$, maxilliped; $d$, maxilla of the outer or second pair; $c$, maxilla of the inner or first pair; $f$, mandible, all enlarged twenty-five diameters; $e^{\prime}$, distal end of onter lobe of first pair of maxillw, enlarged sixty-six diameters.

57. -The same; $a$, last segment of pleon, with attached uropods; dorsal view, enlarged ten diameters; $b$, uropod with dotted adjacent outline of last segment of pleon, enlarged thirty diameters ; $c$, first pair of pleopods; $d$, pleopod of the second pair, from a male, showing stylet, 8 , articulated to the inner lamella; both fignres enlarged twenty diameters.

58.-Cirolana concharum Harger, (p. 378); lateral view, enlarged about throe diameters.

(Figure 53 was drawn by Mr. J. H. Emerton, 55 by Prof. S. I. Smith, 58 by Mr. J. H. Blake, and the others by O. Harger.) 
Fig. 52.

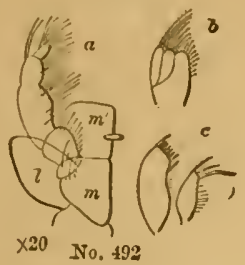

Fig. 57.

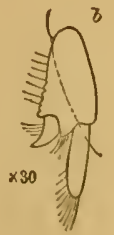

(1)

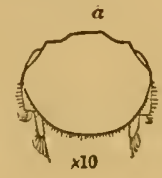

c

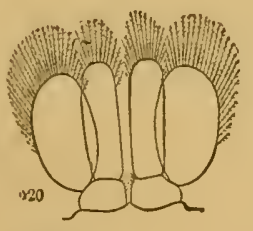

Nio.930.

Fig. 56:

$\int_{x 25}^{a} x_{x 66}^{a} e^{\prime}$

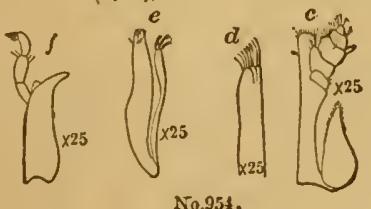

No.951.

Fig. 58 .

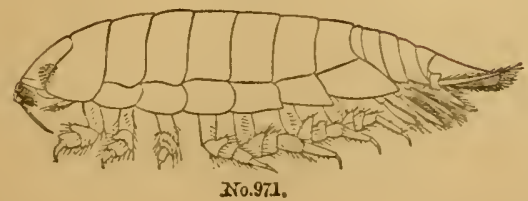

Fig. 53.

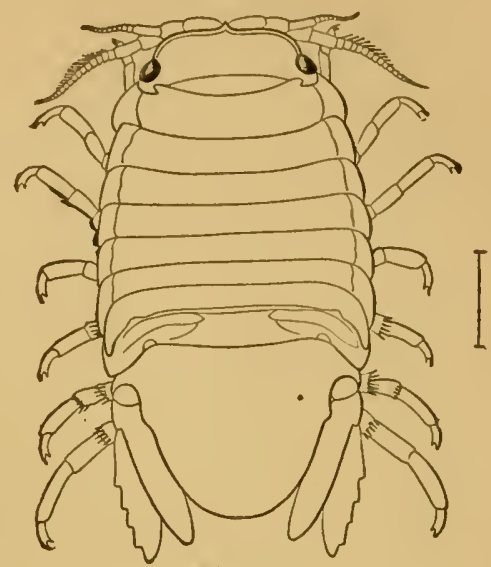

กัo. 532

Fig. 54.

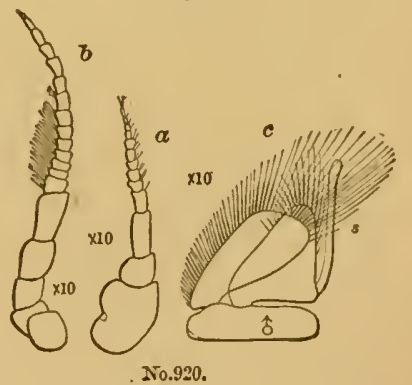

Fig. 55.

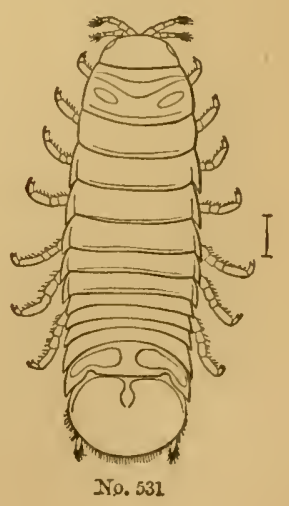





\section{-}




\section{PLATEX.}

FIGURE 59.-Cirolana concharum Harger (p. 378); dorsal view, enlarged about three dianeters. The natural size is shown by the line at the right.

60.-The same; antennula, enlarged ten diameters.

61.-The same; $a$, antenna enlarged ten diameters; $b$, maxilla of the onter or second pair; $c$, maxilla of the inner or first pair; $d$, mandible from the right side, inner view; $p$, palpus; $m$, molar area; the last three figures enlarged five diameters.

62.-The same; a, maxilliped from the right side, exterior view, showing, ?, external lamella; $m$, basal segment; $1,2,3,4,5$, segments of the palpus; $b$, leg of tho fourth pair; both the figures enlarged five diameters.

63.-The same; uropod from the right side; inferior view, enlarged five diameters.

64.- - Eiga psora Kröyer (p. 384); $a$, dorsal and $b$ ventral views of a young individual. The central line indicates the length of the specimen, natural size, which is here enlarged three diameters. Adults attain about the size of the figure.

Figure 65.-Nerocila munda Harger (p. 392); dorsal view of the type specimen, enlarged about four diameters. The natural size is shown by the cross on the right; $a$, uropod, enlarged six diameters.

66.- Egathoa loliginea Harger (p.393); type specimen; $a$, dorsal, and $b$, ventral view, enlarged four diameters. Its natural size is shown by the line between the figures.

(Figure 59 was drawn by Mr. J. H. Blake, the others by 0 . Harger.). 
Fig. 59 .
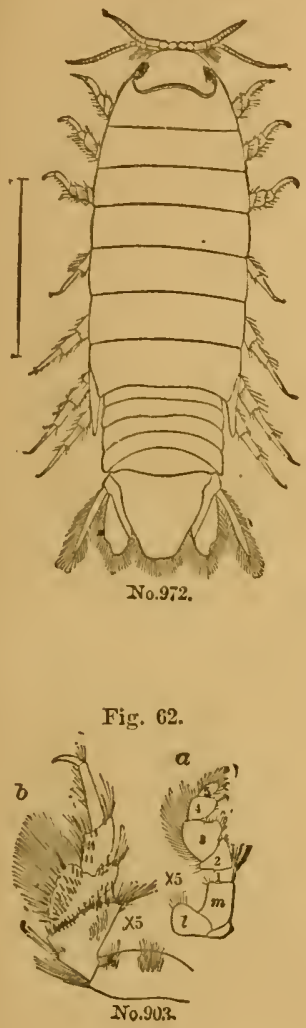

Fig. 60 .

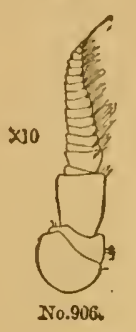

Fig. 63.

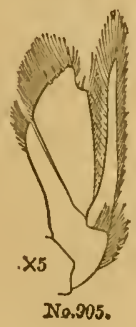

Fig. $6 a$

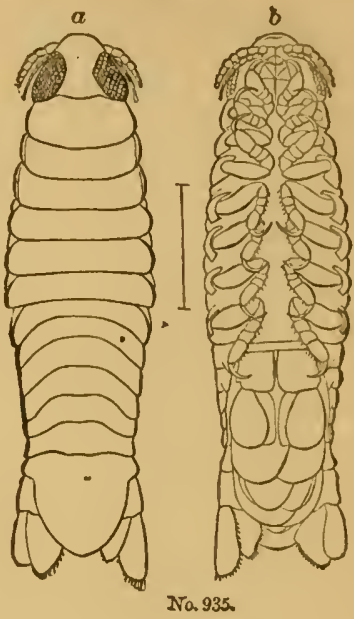

Fig. 61.

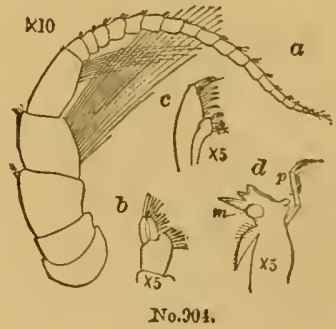

Fig. 65.

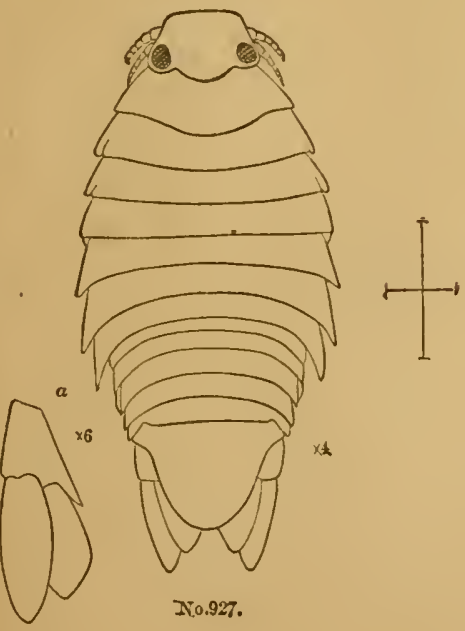

Fig. 64.

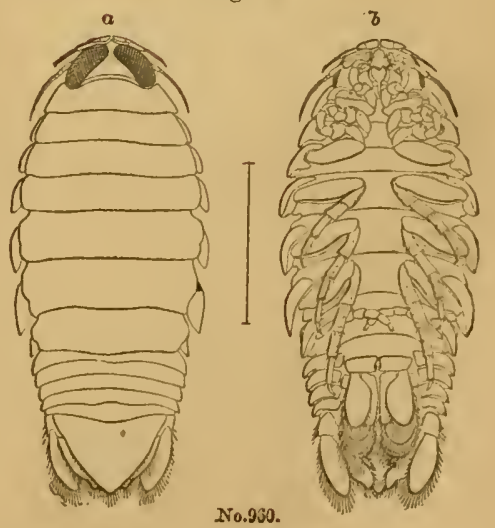





$$
\text { - }
$$

.

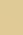

$-$ 


\section{PLATE X1.}

Frguke 67.-Lironeca ovalis White (p. 395); $a$, antennula ; $b$, antenna ; $c$, mandibular palpus; each enlarged twenty diameters; $d$, one of the first pair of legs; $e$, one of the seventh pair of legs; $f$, uropod; each enlarged ten diameters.

68.-Anthura polita Stimpson (p. 398); dorsal view, enlarged four diameters. The natural size is shown by the line at the right; $a$, antennula; $b$, antenna, each enlarged ten diameters; $c$, leg of the first pair; $d$, leg of the third pair; $e$, right pleoped of the first pair, interior view, showing inner ramus without cilia; $f$, pleopod of the second pair from a male, showing stylet articulated to inner lamella; each of the figures $c$ to $f$ enlarged eight diameters; $g$, lateral view of pleon, enlarged six diameters.

69.-The same, $a$, maxilliped, enlarged twenty diameters; $b$, maxilla, enlarged twenty-five diameters; $b^{t}$, distal end of the same, cnlarged sixty diameters.

70.-Paranthura brachiata Harger (p. 402); dorsal view, enlarged about three diameters; natural size shown by the line at the right; $a$, antennula ; $b$, antenna, enlarged eight diameters ; $c$, right maxilliped, enlarged sixteen diameters; $d$, maxilla, enlarged sixtcen diameters; $d^{i}$, distal end of the same, enlarged fifty diameters; $e$, leg of the first pair; $f$, first pleopod from the right side, inner view, showing ciliated inner lamella ; $g$, pleopod of the second pair from a male, showing stylet articulated to the inner lamella; figures $e$ to $g$ enlarged eight diameters.

71.-Ptilanthura tenuis Harger (p. 406); male; dorsal view, enlarged about four diameters; $a$, inferior view of the bead and first thoracic segment, enlarged eight diameters; the flagellum of the antennula omitted; $b$, maxilliped ; $c$, maxilla, each enlarged fifty diameters ; $d$, first right pleopod, seen from within, showing ciliated inner lamella; $e$, second left pleopod, showing stylet $s$ articulated to the inner lamella in the males.

72.-Th same; one of the first pair of legs of a male, enlarged sixteen diameters.

73.-The same; female; dorsal view of the head, onlarged twenty-five diameters.

(Figure 71, excepting $b-d$, was drawn by Mr. J. H. Emerton, the others by O. Harger.) 
Fig. 68.

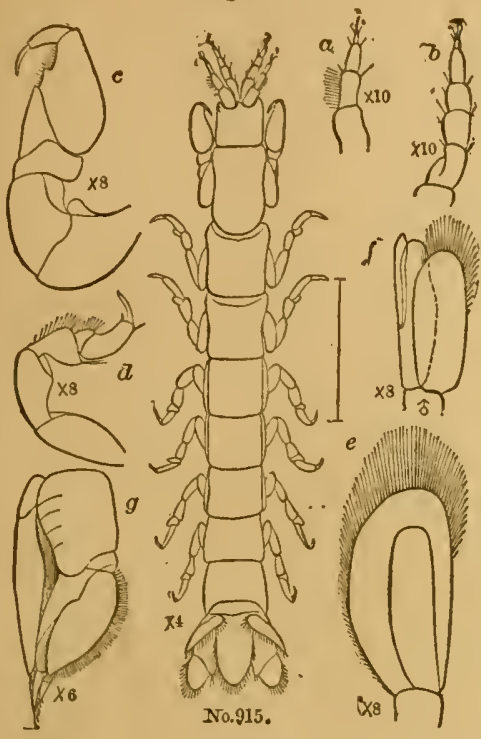

Fig. 69.

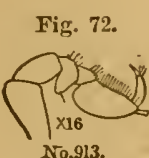

N.0.913.

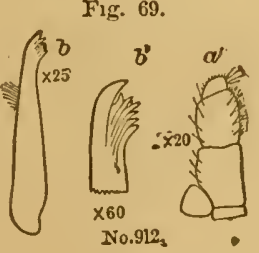

Fig. 67.

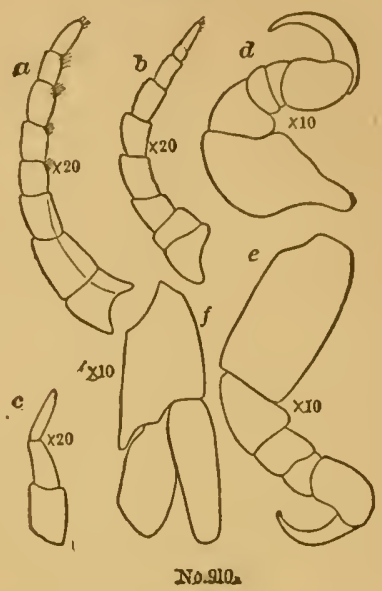

Fig. 73 .

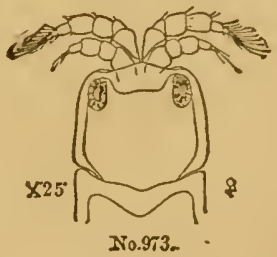

Fig. 70.

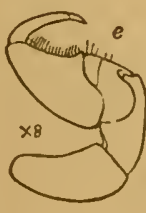

- 16
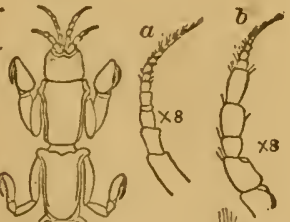

$a^{a}$ as

$\prod_{x 50} \sqrt{8} f$

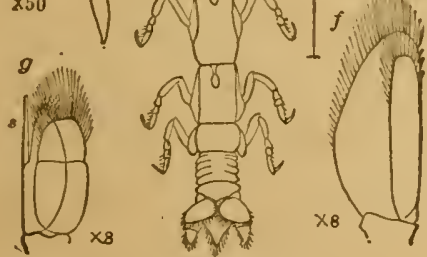

2No.961.
Fig. 71.
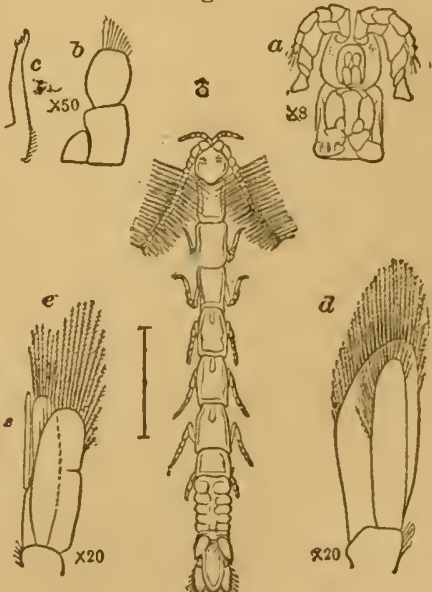

No.916. 



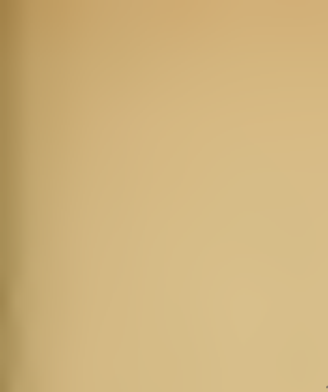

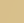

- 


\section{PLATE XII.}

Figure 74.-Ptilanthura tenuis Farger (p. 406); $a$, antennula; $b$, antenna; each enlarged twenty diameters, from a male.

75.-Gnathia cerina Harger (p. 410); male; dorsal view, enlarged ten diameters.

76.-The same; $a$, antennula; $b$, antenna, each enlarged thirty-eight diameters; $c$, mandibles ( $l$, left, $r$, right), enlarged thirty-eight diameters; $\vec{d}$, first leg or first gnathopod from the right side, enlarged twenty-five diameters; all the figures from the male sex.

77.-The same (p. 411); female; dorsal view, enlarged ten diameters.

78.-The same; $a$, one of the first pair of legs or first gnathopod of a female, enlarged thirty-eight diameters; $\delta$, one of the first pair of legs in a young, parasitic individual, enlarged sixty diameters; $c$, pleon, with the last and part of the penultimate thoracic segments of a female, dorsal view, enlarged twenty diameters; $d$, pleopod of a young, parisitic individnal, enlarged sixty diameters; $e$, pleopod of an adult male, enlarged sixty diameters.

79. - The same; young male; dorsal view, enlarged twenty diameters.

80.-Leptochelia algicola Harger (p. 421); male; lateral view, enlarged twenty diameters; natural size indicated by the line above.

(All the figures were drawn from nature by 0 . Harger.) 

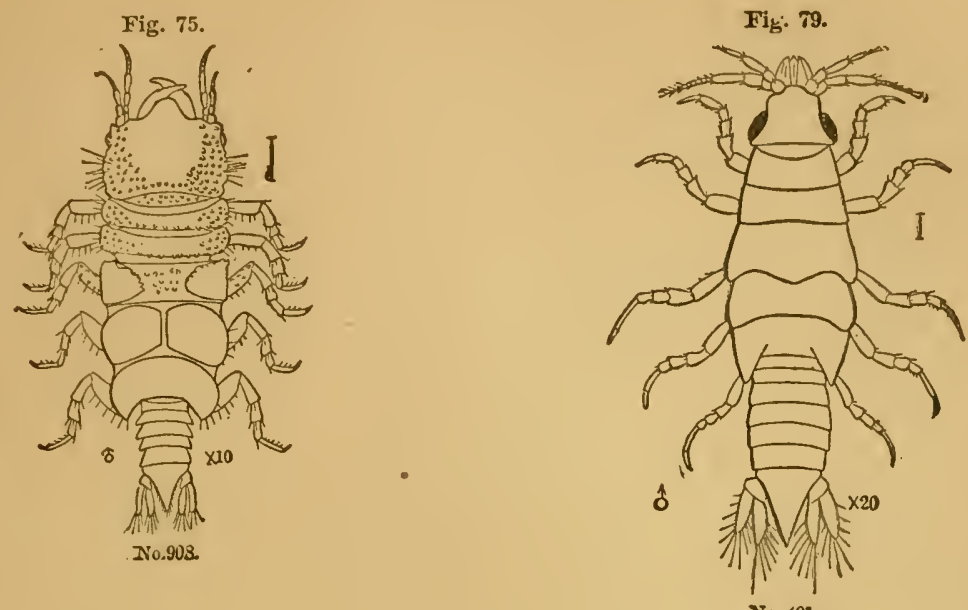

Fig. 78.

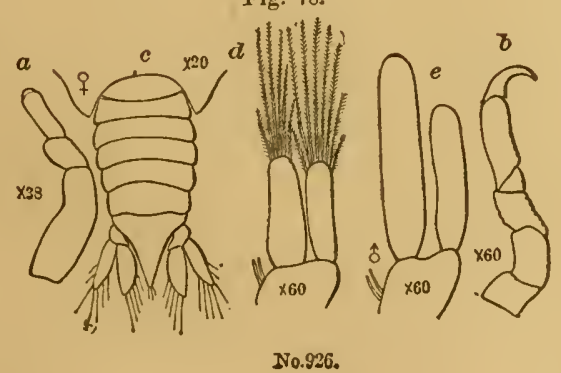

Fig. 77

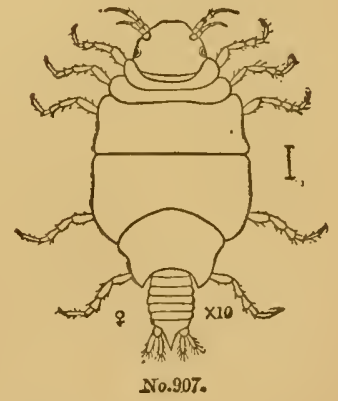

Fig. 74

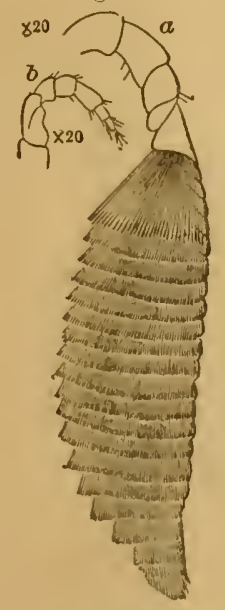

No.909.

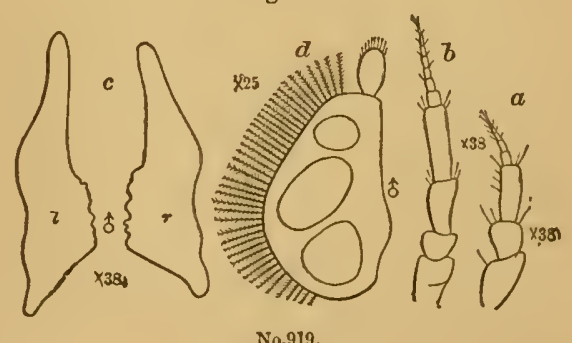

Fig. 80 .

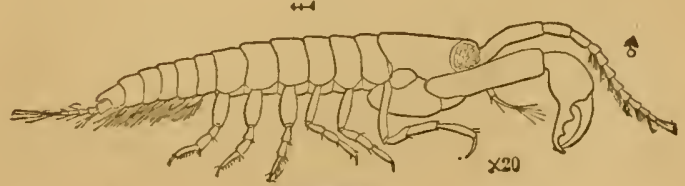

2N0.932. 



\section{PLATE XIII.}

Figdre 81.-Tanais vittatus Lilljeborg (p. 418); dorsal view, enlarged eight diameters. The transverse bands of hairs on the pleon are not suffieiently distinet.

82. - The same; one of the first pair of pleopods, enlarged thirty diameters.

83.-Leptochelia algicola Harger (p. 421); female; dorsal view, enlarged twenty diameters; natural size indieated by the line at the right.

84. -The same; $a$, antennula; $b$, one of the first pair of legs; both from a female speeimen and enlarged twenty-five diameters.

85. - The same; hand, or propodus and daetylus of the first pair of legs, enlarged forty-eight diameters, showing the comb of setw on the propodus.

86. - The same; uropods of a male, enlarged seventy diameters; $b$, basal segment; $i$, inner six-jointed ramus; $o$, outer ramus.

87.-Leptoehelia limieola Harger (p. 424); female; dorsal view, enlarged twenty diameters; natural size shown by the line at the right.

88.-The same; $a$, antennula; $b$, antenna; $c$, leg of the first pair; $d$, leg of the seeond pair; all from the female sex and enlarged twenty-five diameters.

89.-Leptochelia rapax Harger (p. 424); male; dorsal view, enlarged about twelve diameters.

90.-The same; hand, or propodus and dactylus of male, enlarged sixteen diameters.

91.-Leptochelia coeea Harger (p. 427); typo specimen, female; $a$, antennula; $b$, leg of the first pair; $c$, uropod; each enlarged fifty diameters.

(All the figures were drawn from nature by O. Harger.) 
Fig. 89.

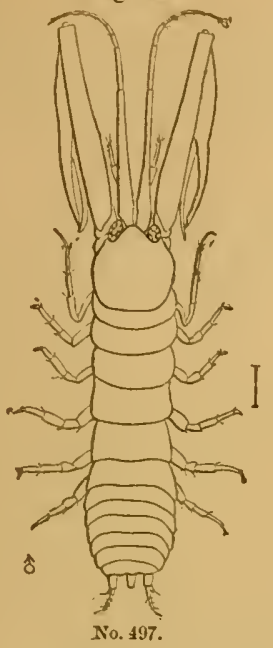

Fig. 82.

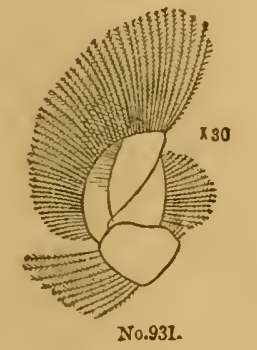

Fig. 83 .

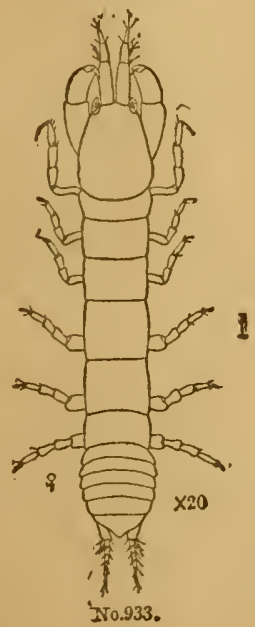

Fig. 90 .

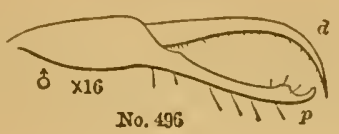

Fig. 85 .

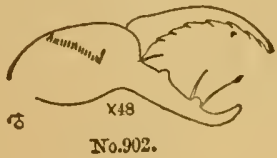

N0.902.

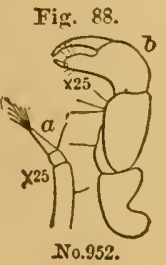

Fig. 81.

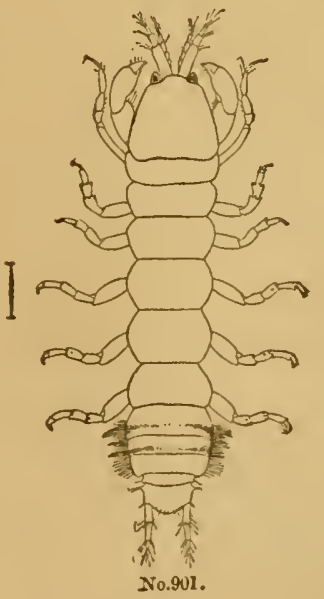

Fig. 84.

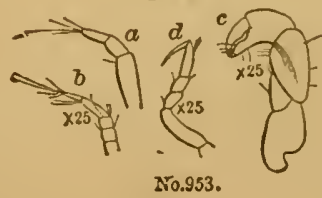

Fig. 86 .

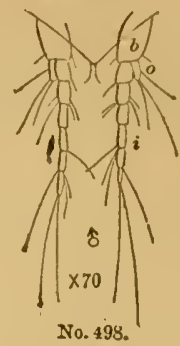

Fig. 91.

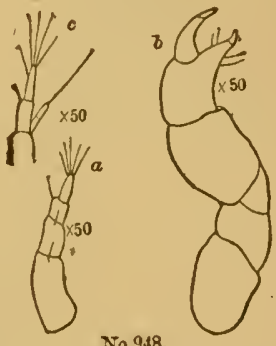

No.9.48.

Fig. 87.

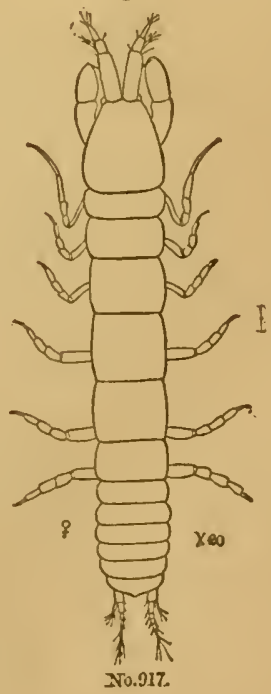





\section{ALPHABETICAL INDEX TO THE REPORT ON THE MARINE ISOPODA OF NEW ENGLAND AND ADJACENT' WATERS.}

[n the following index the first reference for the names of the families, genera, and species here described is to the page on which such description is made. The list of authorities, being alphabetically arranged, is not indexed.]

Abdomen, 298.

Actrocia, 309.

Actoniscus, 309, 305. ellipticns, $309,428,433$.

IEga, 383, 377, 378, 387, 431. concharum, 378 . emarginata, 384. entaill6e, 384 . polita, 381. psorn, 384, 429, 430, 434.

Eggathoa, 393, 391. Ioliginea, $393,428,434$.

Egidær, 382, 300, 303, 377, 430, 431.

Ero-spirantia, 305.

Alitropus, 391.

Anceus, 409, 410. americanus, $410,411$. elongatus, 412 .

Ancoral legs, 300.

Andrews, A, on Limnoria, 375.

Anilocra, 391 . mediterranea, 430.

Anisocheirus, 416.

Antennx, 298.

Antennula, 298.

Anthura, 398, 301, 397, 431. brunnea, 398, 401. carinata, 401. gracilis, $398,401$. polita, $398,406,429,434$.

Antharidæ, 396, 301, 303, 361, 431.

Apsende8, 304, 414, 416, 431.

Arcturidæ, 361, 303, 397, 430, 431.

Arctura8, 361, 363. Baffini, 362.

Armadillidæ, 314 .

Armadillo, 305.

Armida bimarginata, 343 .

Artystone, 390.

Asellidæ, 312, 303, 314, 371, 372, 430, 431.

A sellories, 319. alta, $319,321$.

Asellotes homopodes, 371.

Asellus, 301, 313, 415. communis, 314. Grōnlandicus, 315, 319.

Astacilla, 361, 297, 301, 363, 431. Americana, 364 . granulata, 364, 362, 429, 434 . longicornis, $362,363,366$.

Basis, 300.

Bate, C.Spence, on the incubatory pouoh, 302.
Bate, C. Spence, on terminology of crustacea, 300, Bate and Westwood, on Ero-spirantia, 305. [302. Anceus, 409.

Anthura, 398.

Anthara gracilis, 401.

British Isopoda, 429.

Idotea tricuspidata, 345.

Jæra albifrons, 318.

Limnoria, 372.

Paranthura, 402.

Tannis, 416.

Bathynomus giganteus, 383.

Tanais Ed wardsii, 422.

Bopyridæ, 311, 377, 429, 431.

Bopyrus, 312, 431.

abdominalis, 312.

Hippolytes, 311.

Mysidum, 312.

species, $312,428,433$.

Brevoortia menhaden, 391.

Ballar, J. F., hermaphroditism in Cymothoidw, 391.

Cancer maxillaris, 410.

Carpas, 300.

Cepon distortus, $311,428,433$.

Ceratacanthus, 393.

Chætilia, 336.

Cbela, 300.

Chelura terebrans, $371,376,419,423$.

Chiridotea, 337, 300, 335, 336. cюс⿰丿, 338, 335, 340, 429, 433.

entomon, 337 .

Tufteii, 340, 429, 433 .

Cirolana, 378, 376, 383, 431.

concharum, 378, 298, 428, 434.

polita, $381,429,434$.

truncata, 430 .

Cirolanidæ, 376, 303, 383, 430, 431.

Cleantis, 336.

Cosidotea, 314.

Coldstream, J., on Limnoria, 372.

Conilera, 376, 378. concharnm, 378. polita, 381 .

Cordiner, C., on Astacilla, 363.

Coxa, 300.

Crossurns, 416.

Cuma, 415.

vittatus, 416,418 .

Cymothoi, 383, 391.

œstrum, 377.

oralis, 395.

prægustator, 391. 
Cymothox, 377.

Cymothoidæ, 390,300, 303, 371, 382, 430, 431.

Dactylus, 300 .

Dajus Mysidis, 312, 429, 433.

Dann, J. D., on Ascllidro, 314.

Desmarest, A. G., on Idotea tricuspidata, 345.

Digital process, 300 .

Dohrn, A., on Anceus, 409.

the incubatory pouch, 301, 303.

Tanaicla, 415.

Edriophthalma, 297.

Edwards, II., on Illotea tricuspidata, 345.

Limnoria, 371.

Tanais, 416.

Epelys, 357, 301, 337.

montosus, $359,429,434$.

var. hirsutus, 360 .

trilobus, $358,429,434$.

Epimera, 300.

abdominal, 392.

Erichsonia, 354, 337, 361. attenuata, $356,335,428,434$. filiformis, $355,428,434$.

Eurycope, 332, 329.

cornuta, 333.

robusta, 332, 429, 433 .

Flagellum, 298.

Fleming, J., on Astacilla, 363.

Gadus, 386.

Gammarus Dulongii, 416.

Gegenbanr, C., on Tanaida, 415.

Gelasimus pugilator, 311 .

Geographical distribution, 428.

Gnathia, 410, 297, 302, 357, 431. cerina, $410,429,435$. termitoides, 410 .

Gnathiidr, 408, 300, 301, 303, 431.

Grnathium, 410.

Gnathopods, 300.

Goodsir, II. D. S., on Astacilla, 363.

Gribble, 375.

Grge, 431.

Gyge Hippolytes, 311, 429, 433.

Helleria, 305.

Henopomus tricornis, 322.

Hesse, F., on Anceus and Praniza, 409.

Hippoglossus, 382, 386.

Hippolyte Fabricii, 311.

polaris, 311.

pusiola, 311, $31 \%$.

securifrons, $311,312$.

spinus, 311, 312.

Huxley, T. H., distinction of cephalic and thoracio Ideotea marina, 344.

Idotea, $341,337,431$.

[segments, $302^{\circ}$

acuminata, 344 .

Basteri, 343.

bicuspida, 352 .

cceca, 338.

entomon, 345.

filiformis, 355.

irrorata, $343,342,348,429,430,433$.

marina, 344.

marmorata, 352 .

metallica, 349,350 .

montosa, 359.
Idotea nodnlosa, 352.

pelagica, $343,345,346$.

phosphorea, 347, 342, 346, 429, 433

pulchra, 352.

robusta, $349,342,429,433$.

tricuspidata, $343,345,346$

tricuspis, 344.

tridentata, 344, 345 .

Tuftsii, 310.

variegata, 343 .

Idotoid:e, 335, 301, 303, 361, 397, 430, 431.

Idothea balthica, $344,346$.

nodulosa, 351 .

pelagica, 344 .

robusta, $3 \$ 9$.

Ilyarachna, 334, 329, 335, 429, 433.

Inenbatory pouch, 301.

Ischium, 300.

Isopod, length of, 302.

Isopoda, 297.

aberrantia, 303.

Jæra, 314, 301, 313, 430, 431.

albifrons, $315,318,429,430,433$.

Baltica, 315, 318 .

copiosa, 315.

Krö5eri, 315, 318.

maculata, $315,318$.

marina, 315, 318.

nivalis, 315,318 .

triloba, 358 .

Janira, 319, 313, 430, 431.

alta, $321,299,429,433$.

laciniata, 324 .

maculosa, 319, 322.

spinosa, 323, 429, 433.

Johnston, G., on Astacilla, 362.

Kinahan, J. R., on Actæcia, 309.

Kröyer, H., on Authura carinata, 401.

Muuna, 325.

Tauais Edwardsii, 422.

Labium, 300.

Labrum, 300.

Lamella, external of maxillipeds, 299.

Latreille, P. A., on Idotea tricuspidata, 345.

Leachia, 361, 363. granulata, 364,366 .

Leach, W. E., on Gnathia, 410.

Leacia, 361, 363.

Leg8, 300.

Leidya distorta, 311.

Leidy, J., on Bopyrus species, 312.

Cepon distortus, 311.

Leptochelia, 420, 301, 414, 415, 431.

algicola, $421,429,435$.

coeca, $427,429,435$.

Ed wardsii, 416, 421, 422, 423.

filnm, 426, 429, 435 .

limicola, 424, 429, 435 .

minuta, 416.

rapax, 424, 423, 429, 435 .

Loptophryxus Mrsidis, 312.

Ligia, 305, 310, 311, 415.

Lilljøborg, W., on Jæra albifrons, 318.

Limnoria, 373, 313, 371, 419, 430, 431.

lignorum, 373, 423, 429, 430, 434 .

terebrans, 373. 
Limnoria uncinata, 374, 376. xylophaga, 371 .

Limnoriad $x, 371$.

Limnoriidæ, 371, 303, 431.

Lironeca, 395.

Lironeca, 394, 383. ovalis, $395,300,428,434$.

Lockingtou, W. N., on color of Idotea pulchra, 353.

Loligo Pealii, 394.

Macdonald, J. D., on Tanris vittatus, 417, 419.

Mancasellus, 313.

Mandibles, 299.

Maxillæ, 299.

Maxillipeds, 299.

Mayer, P., Hermaphroditism in Cymothoidæ, 391.

Meinert, F., on Idotea tricuspidata, 346.

Merus, 300.

Mesostenus, 334.

Metzger, A., on Jæra albifrons, 318.

Micropogon undulatus, 396.

Möbius, K., on Jæra marina, 318.

Molar process, 299.

Montagu, G., on Oniscus gracilis, 401.

Müller, F., on Bopyridæ, 30:3, 311.

Leptochelia and Paratanais, 420.

olfactory setæ, 298.

Tanvidæ, 303, 415.

Tanais Edwardsii, 423.

Mullet, 394.

Munna, 325, 313, 430, 431.

Boeckii, 325, 328.

Frbricii, 325, 429, 433.

Munnopsidæ, 328, 303, 314, 430 .

Munnopsis, 329.

Nerocila, 391.

$$
\text { typica, 330, 334, 429, } 433 .
$$

munda, 392, 428, 434.

Norman, A. M., British Cymothoidæ, 430.

Ocelli, 298.

Olfactory setæ, 298.

Oniscidær, 305, 303, 311, 314 .

Oniscoidea, 314 .

Oniscus albifrons, 315 . Balthicus, 344. cœruleatus, 410. entomon, 344. gracilis, 401. marinus, 318. praegustator, 391 . psora, 384, 386.

Operculum, 302, 336.

Ourozeuktes, 377.

Palæmonetes vulgaris, 312.

Palpus, 299.

Pandalus borealis, 312.

Montagui, 312.

Paranthura, 402, 398, 431. arctica, 405 . brachiata, 402, 429, 435 . costana, 405 . norvegica, 404 . tenuis, 406, 407.

Paratanais, 416, 420, 431. algicola, 419,421 . ceeca, 427. forcipatus, 423.
Paratanais limicola, 424, 427.

Pedancle, 208.

Pereion, 298, 300.

Pereiopods, 300 .

Pleon, 298, 301.

Pleopods, 301.

Philoscia, 305.

vittata, $306,429,433$.

Phryxus, 431.

Phryxus abdominalis, 312, 429, 433.

Hippolytes, 312.

Pill-bug, 208, 305.

Platyarthrus, 308.

Pomatomus saltatrix, 396.

Porcellio, 305.

Praniza, 409, 410. cerina, 410, 412. coeruleata, 410. Reinhardi, 413.

Propodus, 300.

Ptilanthura, 405, 398. oculata, 408. tenuis, 406, 429, 435.

Raia, 386.

Rathke, H., on Crossurus, 416, 417.

Respiration, 302, 303.

Rostrum, 302.

Salve-bug, 384.

Sars, G. O., on Eurycope, 332.

Ilyarachna, 334.

Munnopsidæ, 329.

Munnopsis, 331.

Sars, M., on Idotea tricuspiclata, 346.

Jæra albifrons, 318.

Mnnnopsidæ, 329.

Munnopsis, 331.

Schiödte, J. C., on Anthura, 397.

Artystone, 390.

Cymothoæ, 377.

Scyphacella, 307.

arenicola, 307, 428, 433.

Scyphax, 307.

ornatus, 309 .

Serolids, 304.

Smith, S. I., list of Bopyrid:e, 311.

Limnoria xylophaga, 371.

Scyphacella, 307.

Sow.bug, 298, 299, 305.

Sphæroma, 368, 301, 367, 372, 430, 431.

quadridentatum, $368,429,434$.

serratam, 430.

Sphæromidø, $367,303,431$.

Stebbing, T. R. R., on Astacilla, 362.

British Arcturidæ, 430.

Dynamene rubra and viri. dis, 430 .

Tanais vittatus, 417,419.

Stenosoma filiformis, 355 .

irrorata, 343.

Stenotomus argyrops, 396.

Stimpson, W., on Anceus americanus, 410, 413.

Asellodes, 319.

Cirolana concharum, 381.

Cirolana polita, 381 .

Praniza cerina, 412, 413.

Tanais filum, 426. 
Synidoten, 350, 337.

bicuspida, $352,429,433$.

nodulosa, 351, 299, 347, 429, 433.

Syscenus, 387, 383, 391 .

infelix, $387,429,434$.

Tanaida, 415.

Tanaidæe, 413, 298, 300, 302, 303, 304, 431.

Tanais, 416, 297, 301, 414, 415, 431.

Cavolinii, 416, 419.

Dulongii, 416.

Edwardsii, 416, 421, 423.

flum, 420, 421, 423, 426.

hirticandatos, 418.

islandiens, 428.

Savignyi, 423.
Tanais, tomentosus 418,419 .

vittatns, $418,417,420,428,429,431,435$.

Telson, 301.

Templeton, R., on Zenxo, 416.

Tetradecapoda, 297.

Thorax, 298, 300 .

Tylus, 305.

Uropods, 301.

Verrill, A. E., on Chiridotea Tuftsii, 311.

Venns mercenaria, 359.

Westwood, J. O., on Anisocheirus, 416.

White, A., on Limnoriadas, 371.

Willemoes-Suhm, R. $\nabla .$, on Tanais, 418

Wood-lice, 305.

Zeaxo Westwoodiana, 416. 
[Report of the United States Commissioner of Fish und Fisheries. Part vi. For 1878 Opposite page 462.$]$

\section{ERRATA.}

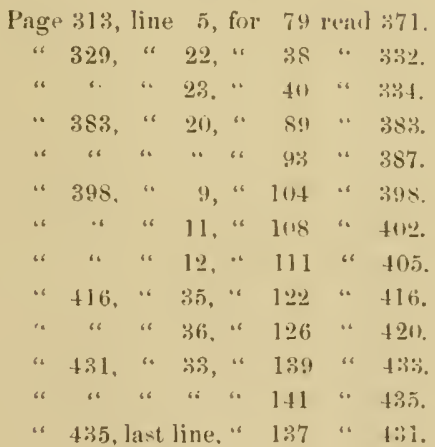

In partial explanation of the above list of incorrect references, the author has to say that he had no opportmity of seeing a correctly paged proof of the article during the year that it was in press at the fovernment l'rinting office. 



$$
\text { - }
$$









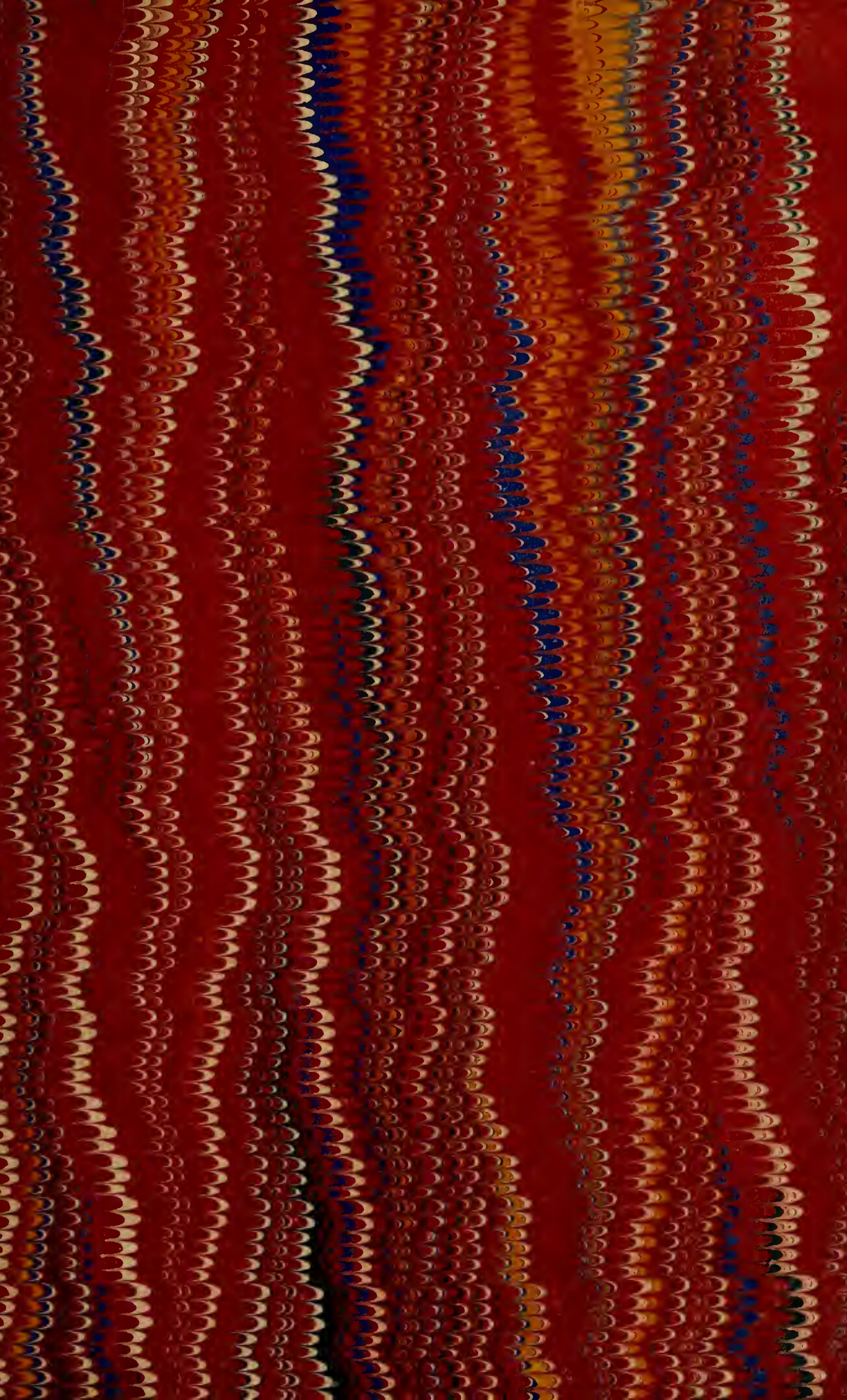




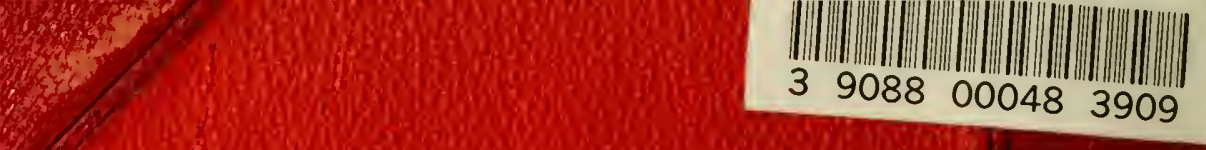

